\title{
Pozitív egész kitevőjű hatványösszegekről Történeti és módszertani áttekintés
}

\author{
Doktori értekezés
}

Molnár István
Témavezető:
Dr. Kosztolányi József egyetemi docens

Dr. Kosztolányi József egyetemi docens

Matematika- és Számítástudományok Doktori Iskola

Szegedi Tudományegyetem

Természettudományi és Informatikai Kar

Bolyai Intézet 
Édesapám emlékére 


\section{Tartalomjegyzék}

1.

BEVEZETÉS

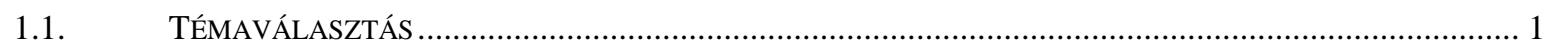

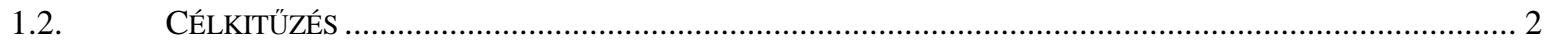

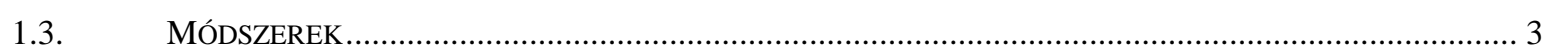

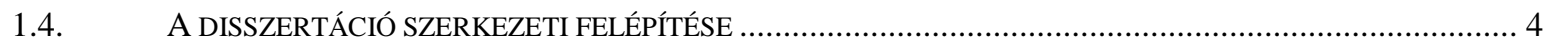

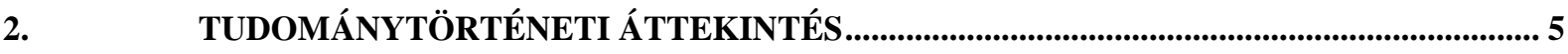

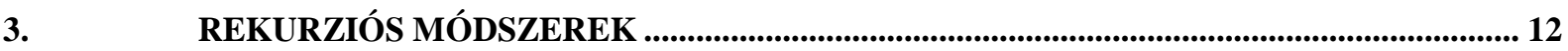

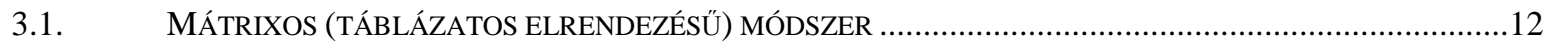

3.1.1. Rekurziós összefüggés az első módszer segítségével .............................................................12

3.1.2. Speciális esetek a kapott rekurziós összefüggésre ...................................................................14

3.1.3. A „mátrixos” módszer alkalmazása alternáló összeg esetére ....................................................18

3.1.4. Speciális esetek az alternáló összeg esetén kapott összefüggésre...............................................20

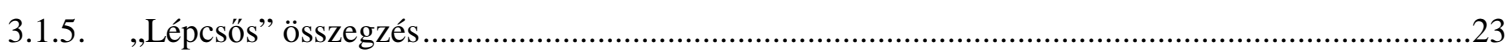

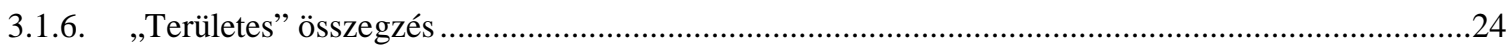

3.2. A REKURZIÓS ÖSSZEFÜGGÉS LEVEZETÉSE EGY SPECIÁLIS AZONOSSÁG FELHASZNÁLÁSÁVAL ..........25

3.2.1. A módszer és az előálló rekurziós összefüggés .........................................................................25

3.2.2. A kapott összefüggés néhány konkrét esetben......................................................................26

3.2.3. Rekurziós összefüggések előállítása a második módszer segítségével.........................................29

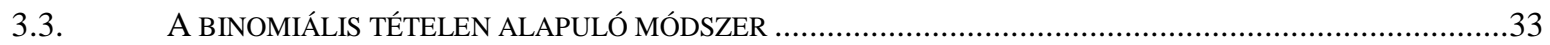

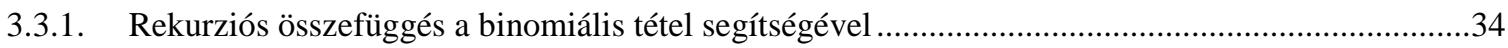

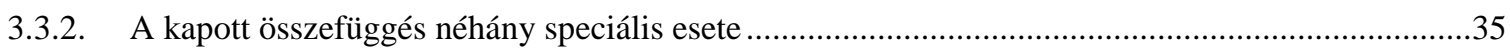

3.3.3. Általánosítás a számtani sorozatok esetére a binomiális tételen alapuló módszer segítségével .......36

3.3.4. Speciális esetek a számtani sorozatokra vonatkozóan kapott rekurziós összefüggésre ....................38

3.3.5. A binomiális tételen alapuló módszer alkalmazása alternáló összeg esetére..................................45

3.3.6. Az alternáló összegre kapott összefüggés speciális esetei ..........................................................46

3.3.7. Általánosítás a binomiális tételen alapuló módszer használatával a számtani sorozat alternáló

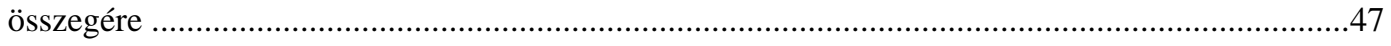

3.3.8. Speciális esetek a számtani sorozat alternáló összege esetén kapott összefüggésre ........................49

3.4. REKURZIÓS ÖSSZEFÜGGÉS LEVEZETÉSE A SZIMMETRIA FELHASZNÁLÁSÁVAL................................52

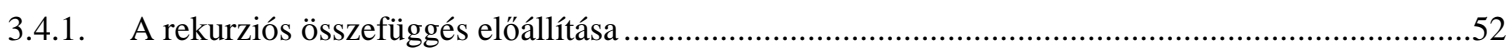

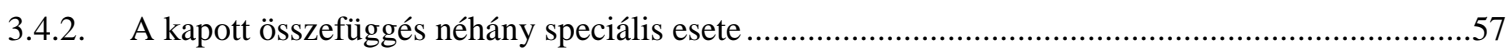

3.4.3. A Bell- és Stirling-számok megjelenése ....................................................................................58

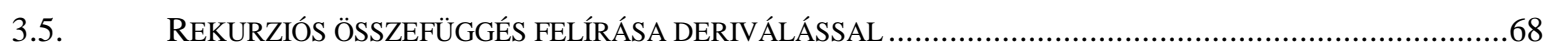

3.5.1. Rekurziós összefüggés előállítása differenciálszámítás segítségével .........................................68

3.5.2. Általánosítás a differenciálszámításon alapuló módszer segítségével a számtani sorozatok

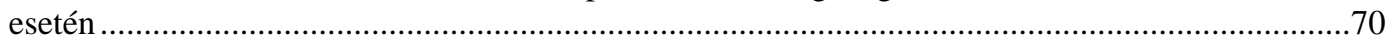

3.5.3. A differenciálszámítást felhasználó módszer alkalmazása az alternáló összeg esetére ...................72

3.5.4. Általánosítás a deriválást alkalmazó módszer segítségével a számtani sorozat alternáló összegére ..... 
4.

4.1. ÖSSZEFÜGGÉS LEVEZETÉSE A DIFFERENCIASOROZATOK SEGÍTSÉGÉVEL ..........................................78

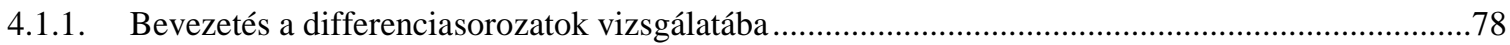

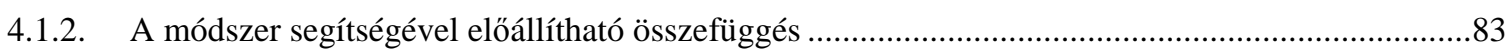

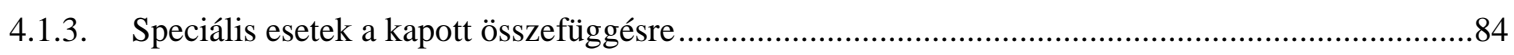

4.1.4. Speciális esetek a kapott összefüggésre számtani sorozatok esetén ................................................86

4.2. ÖSSZEFÜGGÉS LEVEZETÉSE LINEÁRIS ALGEBRAI ESZKÖZÖKKEL ……………....................................91

4.2.1. Összefüggés felírása lineáris algebrai eszközök segítségével.........................................................91

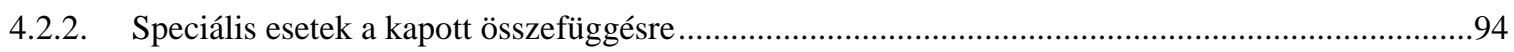

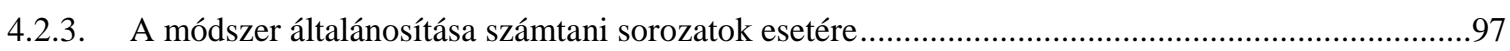

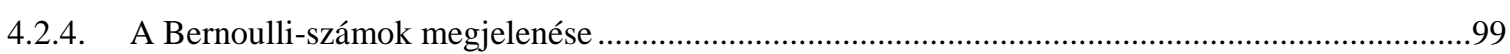

4.2.5. A Stirling- és Bernoulli-számok közötti kapcsolat ..................................................................... 105

4.2.6. Kapcsolat az első $n$ pozitív egész szám $p$-edik hatványának összege és a Bernoulli-számok

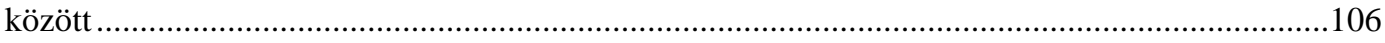

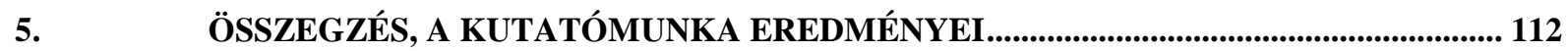

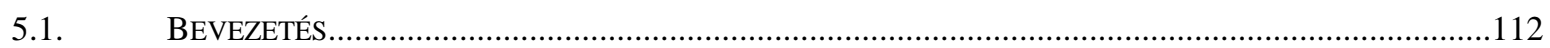

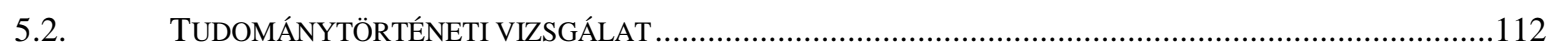

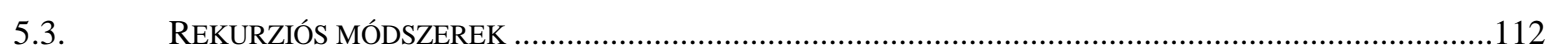

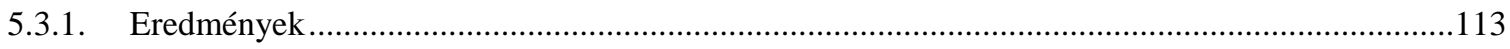

5.4. NEM REKURZIÓRA VEZETỎ MEGOLDÁSI MÓDSZEREK ………………........................................118

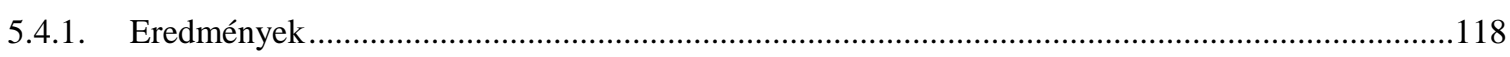

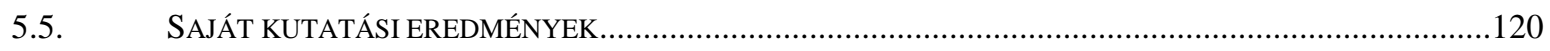

5.5.1. Saját kutatási eredmények a rekurziós módszerek körében ............................................................120

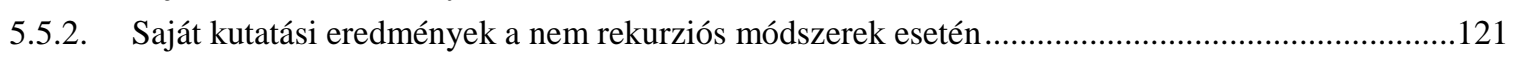

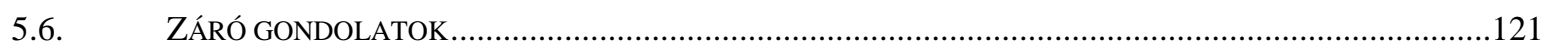

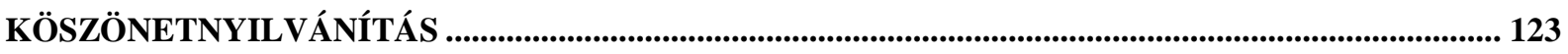

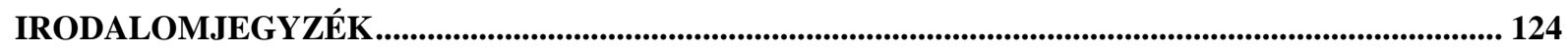

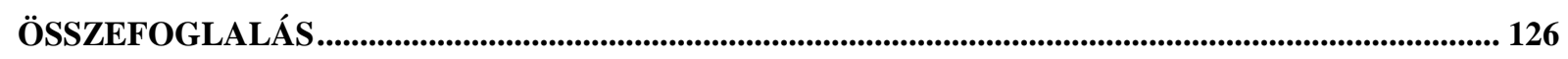

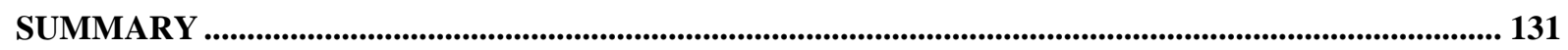

FÜGGELÉK: A TÉMAKÖRHÖZ KAPCSOLÓDÓ FELADATOK........................................................ 136 


\section{Bevezetés}

Ha nagy vonalakban áttekintjük a matematika tudománytörténeti fejlődését, akkor jól láthatóan kirajzolódik a diszciplína fejlődésében két, egymással szoros összefüggésben lévő tendencia. Egyrészt ez a tudományág a logikus gondolkodás szigorú szabályai szerint, magas fokú absztrakcióval fogalmakat definiál, axiómákat fektet le, törvényszerüségeket állapít meg, tételeket bizonyít, sejtéseket fogalmaz meg, összefüggéseket ír le, azaz folyamatosan új és új konkrét matematikai eredményeket mutat fel, növelve ezzel az emberiség matematikai tudásanyagát. Másrészt e folyamat során a feladathoz, a problémához igazodó ismert és új módszereket használ fel, állandóan megújítja a rendelkezésre álló metodikai apparátust, s ezzel fokozatosan gazdagítja saját tudományos eszköztárát. Egy matematikai probléma megoldása és az ahhoz kötődő módszerhasználat tulajdonképpen ugyanannak a tudományos munkafolyamatnak két egymásba fonódó, egymást átható, elszakíthatatlan oldala. Talán nem tévedünk nagyot, ha azt állítjuk, hogy a módszerek fontossága a matematika tudományának müvelése során nem megkérdőjelezhető. Hiszen a matematikus számára a módszerek széleskörü ismerete éppen olyan nagy jelentőséggel bír, mint a fejében lévő megszerzett tudásanyag, az elmélyült gondolkodás, vagy éppenséggel az esetleg felhasználható matematikai intuíció. Példák sokasága igazolja, hogy a célirányos és helyes módszerhasználat nemcsak hogy fontos tényező, de adott esetben akár a legfontosabb záloga lehet a kitüzött feladat sikeres megoldásának.

\subsection{Témaválasztás}

Jelen dolgozat témaválasztása a „megoldásra váró feladat - felhasznált módszerek” dichotómia egységének, illetve magának a metodikának a fontossága okán került meghatározásra. Vizsgálatunkat egy konkrét, megoldásra váró feladat, az

$$
S_{p}=1^{p}+2^{p}+3^{p}+\ldots+n^{p}, \text { ahol } n, p \in N, n \geq 1
$$

hatványösszegek kiszámításának problematikája apropóján az alábbiakban fogalmazzuk meg:

1. Munkánkban tömör summázatát adjuk a fenti probléma történeti fejlődési aspektusának, s itt leírjuk, hogy az egyes korokban és a Föld különböző társadalmaiban kik meddig jutottak el a megoldásban (milyen részeredményeket értek el), ki, mikor és hogyan oldotta meg a feladatot teljes körüen.

2. A matematika különböző területeiről származó hét módszer felhasználásával matematikai alapossággal - rendre kiszámítjuk az $S_{p}$ hatványösszeget, minden esetben bemutatva nemcsak az eredményeket, hanem a módszer, a gondolkodás logikáját is, végigvezetve az olvasót a részletszámításokon és megadva a kapott végeredményt is.

3. Mindegyik módszernél bemutatjuk a kapott általános formula néhány konkrét esetét, többek között ezzel is szemléltetve több „közismert”, a középiskolai matematikai tananyagban is szereplö, összegzési képletet. 
4. Több módszer bemutatásánál általánosításokat végzünk (számtani sorozatok, alternáló összegek esetére), illetve kapcsolódási pontokat keresünk a matematika más területei felé.

5. Közreadunk 32 olyan matematikai feladatot, amelyek segítségével bemutathatjuk a hatványösszegek képleteinek sokszínű felhasználhatóságát, ízelítőt adva ezen matematikai tudásanyag empirikus hasznosíthatóságáról is (terjedelmi korlátok okán ezek a függelékbe kerülnek).

\subsection{Célkitüzés}

A fent említett megoldandó feladathoz és a vizsgálandó területhez, azaz a módszertani apparátusok hasznosíthatóságának világához igazodóan az értekezés célkitüzései az alábbiak:

1. Egyik legfontosabb célunk átfogó módon tárgyalni az $S_{p}$ kiszámításának módszertanát - részben támaszkodva a szakirodalom eredményeire, egyes esetekben kiegészítve azokat. Másrészt bemutatjuk az általunk felkutatott új módszertani eredményeket.

2. A hét alkalmazott módszer lehető legteljesebb körü „körüljárásával” bizonyítani kívánjuk egyrészt e területen a módszerek gazdag felhasználásának lehetőségét, másrészt azt, hogy egy-egy probléma megoldása során gyakran nagyon eltérö problémamegközelítések is helyénvalóak lehetnek, s ezen differenciált gondolkodási utak, „ösvények” végső soron ugyanahhoz a végeredményhez vezetnek - mindez együtt egyúttal újabb bizonyítékát is adja a matematika „szépségének”. Főiskolás hallgatóink körében végzett felméréseink igazolják egy adott témakörhöz tartozó matematikai probléma különböző módszerekkel való megoldásának hasznosságát, ez nagyban segíti a megértést, a matematikai tudásanyag gazdagodását, és a rendelkezésre álló módszerek bővülését [25].

3. Részben a kutatási folyamatból adódóan, részben a jelen disszertáció megírása során szerzett tapasztalatok eredményeként, részben pedig a korábbi szakmai-oktatási „elöéletünk” tapasztalataiból (középiskolai és egyetemi oktatói gyakorlatunkból) táplálkozva rövid értékelését adjuk az egyes módszerek előnyeinek és hátrányainak igyekezvén értékítéletünkben mértéktartóak maradni, nem feledve azt, hogy ezek az értékelések nem matematikai igazságok, hanem nagyon is vitathatók, hiszen az emberi szubjektumtól függenek.

4. Az egyes módszerek áttekintésénél - ahol erre mód nyílik - összeköttetéseket, „hidakat” szándékozunk találni a matematika más területei felé (pl. Bernoulli- és Stirling-számok).

5. Didaktikai vonatkozásban pedig célunk annak behatárolása, hogy mely módszerek, miért és miként használhatók fel a középiskolai matematika világában, és melyek azok, amelyek inkább a föiskolai, egyetemi matematika oktatás körébe valók. 


\subsection{Módszerek}

A matematika az a tudomány, ahol egy adott problémát sokféle, olykor nagyon különböző szemlélettel lehet megvizsgálni, s megoldani. Ez lehetőséget teremt egyrészt a különböző területek összekapcsolására, másrészt az adott feladat többféle úton való megoldásával lehetővé válik a megoldási módszerek elemző összehasonlítása is. Ennek okán értekezésünk bevallottan határterületi munka kíván lenni a „tiszta matematika” müvelése és egy klasszikus matematikai módszertani munka között. Hiszen egyfelől igyekszünk a matematikai tudományos ismeretanyaghoz valamelyest hozzájárulni azzal, hogy - egy konkrét probléma kapcsán - új módszereket, alkalmazásokat mutatunk be, ahol lehet általánosításokat teszünk, valamint kapcsolatot keresünk a matematika más területei felé. Ugyanakkor az értekezés jelentős részben módszertani karakterü is, hiszen - egy konkrét probléma megoldása kapcsán - a felhasznált matematikai módszerek alkalmazhatóságát, előnyeit, hátrányait elemzi.

A matematikán belüli integrációnak tulajdonképpen pontosan az a lényege, hogy az adott problémát különböző irányokból vizsgáljuk, próbáljuk megoldani, ezáltal különböző területeket kapcsolunk össze. Egy probléma, egy feladat többféle úton történő megoldásának összevetése lehetővé teszi a megoldási módszerek elemző összehasonlítását is. Épp ezért érdemes egyfajta „módszertani kincsestárat” összegyüjteni, és összehasonlítani az alkalmazott módszereket.

Közelebbröl az értekezés a széles matematikai módszertani kínálatból két módszerfajtát vizsgál: egyrészt rekurziós összefüggésre vezető metodikákat mutat be, másrészt nem rekurziós képletekre vezető módszerekkel operál.

Először a rekurziós módszerekkel kerül a probléma megoldásra. Itt öt módszert mutatunk be a következők szerint:

1. az első a mátrixos (táblázatos elrendezésü) módszer (ezen belül háromféleképpen összegzünk),

2. másodikként egy speciális azonosság felhasználásával rekurziós összefüggésre vezető módszer következik,

3. harmadszorra a binomiális tétel segítségével vezetjük le a rekurziót,

4. a negyedik módszert a szimmetria felhasználásával előálló rekurzió fémjelzi,

5. az ötödik metodikánk pedig a deriválással felírható rekurziós formula megadása.

A második nagy módszercsoport a nem rekurziós formulára vezető eljárások. Ezek közül kettővel foglalkozunk, éspedig:

1. először a differenciasorozatok segítségével felírt összefüggést adjuk meg,

2. másodjára pedig a lineáris algebra eszközeivel levezetett formulát írjuk fel.

A disszertáció módszertani vonatkozásainál mindenképpen meg kell még említeni azt a tényt is, hogy értekezésünk metodikailag szélesebb területet fog át, mint a matematikában használt módszerek. Ugyanis „tisztán matematikai” módszerek mellett felhasználtunk más tudományágaknál szokványos módszereket is. Így megjelenik munkánkban a forrásfeldolgozás és -újraértelmezés, az elemzés-összehasonlítás módszere (a különböző módszerek előnyeinek, hátrányainak taglalása), valamint az ábrázolástechnikai módszer is.

Ez utóbbi módszer különösen fontos számunkra, ugyanis a matematikatanítás általánosan képző céljai között olyan fontos képességek fejlesztése jelenik meg, mint például a 
problémamegoldó képesség, az indoklási, következtetési, bizonyítási képesség vagy a matematikai kapcsolatok, összefüggések felismerésének képessége. E képességek fejlesztésében nagyon fontos szerepe van (lehet) az ismeretek képi (ikonikus) bemutatásának. Képi reprezentációk segítségével a tanulók jobban megértik a fogalom, az elv, a probléma lényegét, jelentőségét, többségük jobban emlékszik az adott dolog vizuális megjelenésére, mint az analitikus aspektusokra. A nemzetközi matematika didaktikai szakirodalomban erősödik az a felfogás, hogy a vizuális reprezentációt a középiskola felsőbb osztályaiban, sőt a felsőfokú oktatásban is alkalmazni kell, ezzel is segítve a jobb megértést. Ennek okán szükségesnek tartottuk, hogy több fejezetben is szemléletes bizonyításokkal „füszerezzük” az adott anyagrészt.

A problémamegoldó képesség fejlesztésében talán a legfontosabb rész a már megoldott feladattal, problémával való „bíbelődés”. Ha nem elemezzük tovább a már megoldott feladatainkat, akkor nem jutunk könnyen magasabb szintre. Áttekintve a már megoldott feladatot, problémát és a megoldás végső alakját, sokféle megfigyelést tehetünk: felkutathatjuk a megoldásban a döntő gondolatot, esetleg tudatosíthatjuk, hogy új módszert találtunk, amelyet a korábban leírtakkal, alkalmazottakkal összevethetünk. A már megoldott feladatokon, problémákon való további munka, a megoldásban való elmélyülés eredményeképpen új és jobb megoldásokra bukkanhatunk, érdekes tényeket fedezhetünk fel, illetve rendezett, alkalmazható tudásra teszünk szert. Éppen ezért a mellékletben szereplő feladatgyüjtemény számos feladatában igyekeztünk általánosításokat végezni, általánosabb állításokat is megvizsgálni.

\subsection{A disszertáció szerkezeti felépítése}

A dolgozat szerkezetileg öt fejezetre tagolódik. Némely fejezetek további alfejezetekre, illetve kisebb részfejezetekre oszlanak. Az értekezés logikailag a következőképpen épül fel: a bevezető fejezet után először a hatványösszegek kiszámítása problematikájának egy áttekintő történelmi bemutatását kapja az olvasó. A harmadik fejezet a rekurziós összefüggésekre vezető metodikákat tárgyalja. Ezután a nem rekurziós formulákra vezető módszerek következnek, majd a munka záró fejezetében az egyes módszereket összehasonlítva megvizsgáljuk azok előnyeit, hátrányait, valamint összegezzük az értekezés legfontosabb megállapításait, eredményeit, s végezetül a szakirodalomból átvett ismeretektől elhatároljuk saját eredményeinket.

A munka két fö fejezetében - a harmadik és negyedik fejezetben - a belső (fejezeten belüli) logikai rend a következőképpen alakul: az egyes módszerek tárgyalásánál elöször mindig levezetjük az $S_{p}$-t megadó általános formulát, majd ezután bemutatjuk az összegzési képlet néhány speciális esetét. Egyes módszereknél általánosítunk a számtani sorozatok, illetve az alternáló összegek eseteire, továbbá kapcsolatokat keresünk a matematika különböző területei felé. Minden módszer tárgyalása végén rövid értékelését adjuk az adott módszernek. 


\section{Tudománytörténeti áttekintés}

A hatványösszegek kiszámításának problematikája az ókorig nyúlik vissza. A csillagászat, a földmérés és a geometria természetszerüleg igényeltek matematikai ismereteket. Az ókori potamikus kultúrákban a matematikát az írnokiskolákban tanították. Azt, hogy milyen fokon kezdték a tanítást, és hogy milyen volt egy átlagos írnok tudása, nem tudjuk megmondani, de mind több bizonyítékot találunk az óbabiloni és óegyiptomi kor írnokainak komoly matematikai jártasságára. Az egyiptomiak csak elemi törteket használtak, külön eljárásokat alkalmaztak a szorzás és osztás müveletére, melyeket papiruszokon, táblákon tartottak nyilván (lásd [21]). A babiloniak táblákat használtak a négyzet, a négyzetgyök, a köb és a köbgyök számítására, táblázatokat a négyzetek és köbök összegeinek meghatározására stb. (lásd [5] 41-64. o.). A kutatók olyan táblákat is találtak, amelyek adott számok egymás utáni hatványait tartalmazzák, sőt olyanokat is, amelyek a négyzetszámok összegével vagy a számtani sorozatokkal foglalkoznak.

Az első, igazán komoly eredményeket az ókori görög tudósok érték el. PÜTHAGORASZ (PITAGORASZ) (i.e. 569-475) tudományos eredményei elválaszthatatlanul összekeveredtek tanítványai munkáival, éppen ezért legtöbbször közelebb járunk az igazsághoz, ha a püthagoreusokra gondolunk akkor is, amikor Püthagoraszt emlegetjük. Püthagorasz iskolájában szembetünő az a hajlandóság, hogy a számokat a geometriával összekössék; igen sok számtani problémát a geometriai ábrázolás segítségével oldottak meg, így például a számtani sorozatok összegének kiszámítását. Igen valószínű, hogy az ún. figurális (poligonális és piramidális) számok fogalma már ebben az iskolában megjelent. A püthagoreusok a figurális számok segítségével különböző összefüggéseket állapítottak meg. Például:

- az n-edik háromszögszám az első $n$ pozitív egész szám összege (2.1. ábra),

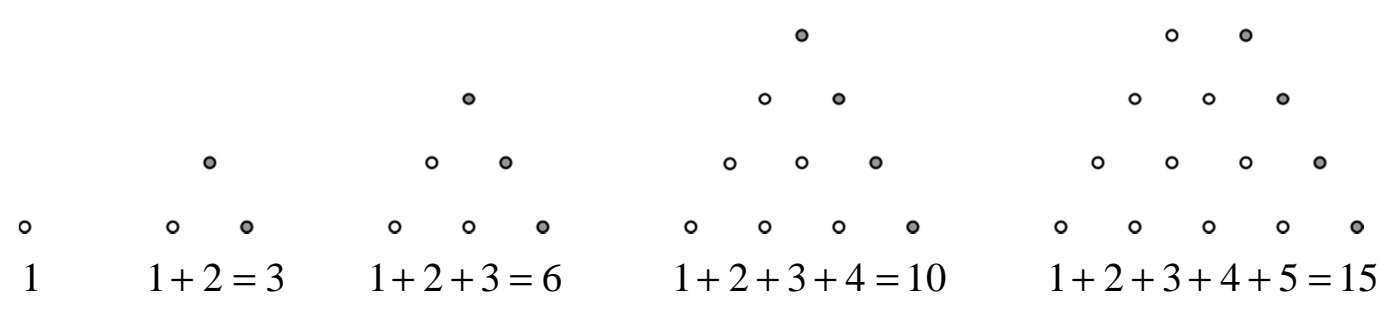

\section{1. ábra}

Általánosan: $1+2+3+\ldots+n=\frac{n(n+1)}{2}$. 
- $\quad$ az $n$-edik $n(n+1)$ alakú téglalapszám az első $n$ pozitív páros szám összege (2.2. ábra),

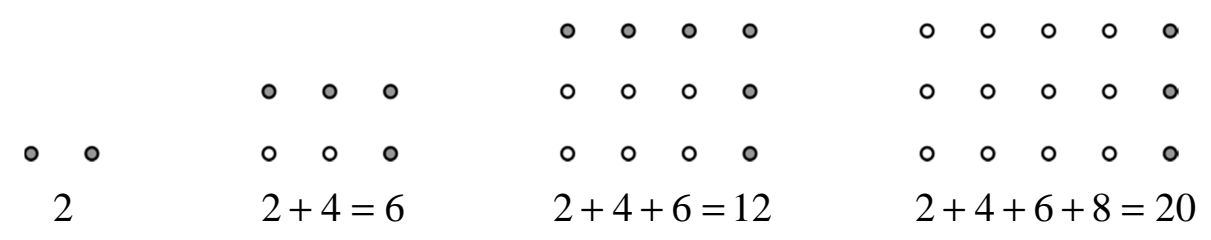

\section{2. ábra}

Általánosan: $2+4+6+\ldots+2 n=n(n+1)$.

- $\quad$ az $n$-edik négyzetszám az első $n$ pozitív páratlan szám összege (2.3. ábra).

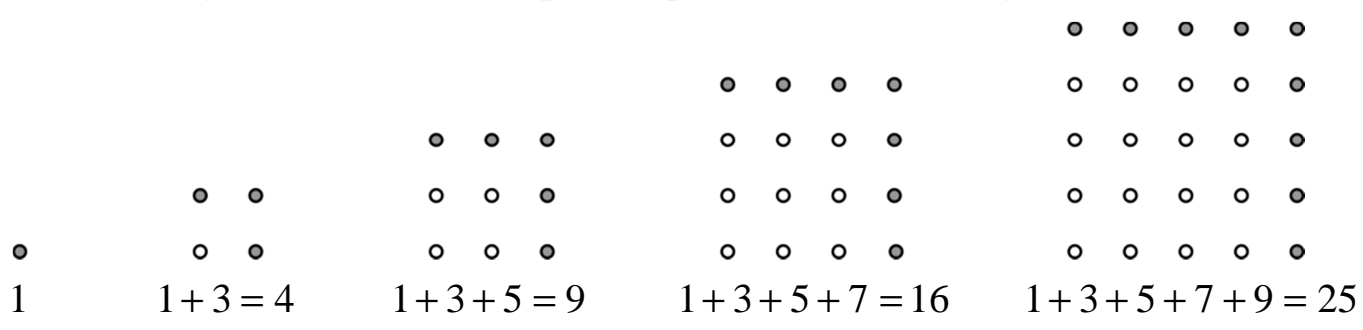

\section{3. ábra}

Általánosan: $1+3+5+\ldots+(2 n-1)=n^{2}$.

A püthagoreusok a figurális számok között sok más érdekes kapcsolatot is felfedeztek. Így például:

- minden háromszögszám kétszerese téglalapszám,

- két egymás utáni háromszögszám összege négyzetszám,

- a 6 az egyetlen szám, amely háromszögszám és $n(n+1)$ alakú téglalapszám is,

- minden háromszögszám nyolcszorosának eggyel növelt összege négyzetszám stb.

ARKHIMÉDÉSZ (i.e. 287-212) majdnem biztosan ismerte a négyzetösszegre vonatkozó képletet, hiszen A konoidokról és a szferoidokról címü könyvében a forgásellipszoid térfogatának kiszámításánál felhasználta a - mai jelölésekkel $(n+1) n^{2}+(1+2+3+\ldots+n)=3\left(1^{2}+2^{2}+3^{2}+\ldots+n^{2}\right)$ összefüggést. Azonban nem az összegképletet - amit már előtte is jól ismertek -, hanem más utat választva becslést adott rá (igazolás nélkül), éspedig a következőt: $\frac{n^{3}}{3}<1^{2}+2^{2}+3^{2}+\ldots+n^{2}<\frac{(n+1)^{3}}{3}$ (lásd [9] 189-194. o.). Valószínű, hogy ez a két egyenlőtlenség valamilyen geometriai meggondolásból származott.

HÜPSZIKLÉSZ (HYPSZIKLÉSZ) (i.e. II.sz.) egyfelől a számtani sorozat összegének kiszámítására ad összefüggést a sorozat középső tagjának (páratlan számú tag esetén) és a két középső tag összegének (páros számú tag esetén) segítségével, másrészt pedig ezen számtani sorozatok összegét, mint poligonális számokat adja meg.

Ennek bemutatásához tekintette mindazon sorozatokat, amelyeknél az első elem 1: 
- ha az állandó differencia (d) 1, akkor az összeg háromszögszám lesz,

- ha $d=2$, akkor négyzetszám,

- ha $d=3$, akkor ötszögszám stb.,

- általánosan pedig a szögek, valamint az oldalak száma kettővel nagyobb, mint a különbség.

Tehát minden 1-gyel kezdődő számtani sorozat tagjaiból szabályos sokszögeket alkotott az alábbi módon (2.4. ábra):
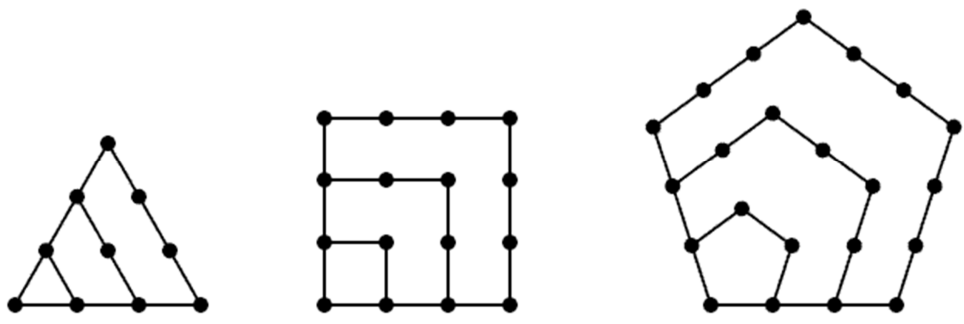

2.4. ábra

NIKOMAKHOSZ (I.sz.) legfontosabb müve a két könyvből álló Bevezetés az aritmetikába. A II. könyv a figurális számokról tesz említést. Ezeket a számokat az 1-gyel kezdődő számtani sorozatok összegzésére használja fel és így vezeti le egyes tételeit, mint például azt, hogy 1től kezdődően tetszőleges számú egymás utáni páratlan egészek összege mindig teljes négyzetet ad. A köbös számokról is nevezetes összefüggést állapít meg, amelyet valószínüleg ő maga fedezett fel, éspedig hogy a köbös számok mindig páratlan számok szomszédos tagjainak összegéből származnak, úgy hogy annyi tagot kell venni, mint ahányadik szám köbét akarjuk. Azaz $1^{3}=1 ; 2^{3}=3+5 ; 3^{3}=7+9+11 ; 4^{3}=13+15+17+19$ stb.

Szintén jelentős eredményeket könyvelhet el ebben a témakörben az ó- és középkori kínai matematika. Ennek megismeréséhez tanulságos a Szuan csing (Matematikakönyv) átlapozása (lásd [9] 310-347. o.). Ez a könyv az i.e. 250 körüli években keletkezett összefoglaló mü, amelyből megismerhető Kína egész matematikája. Amíg a könyv végleges tartalmát és alakját elnyerte (ez a folyamat több évszázadon keresztül tartott), addig többen átdolgozták és kiegészítették. A könyv kérdés-felelet formában 246 feladatot tartalmaz. Mindegyik feladatnak közli a megoldási módját és megfogalmazza - olykor általánosan is - az eredményhez vezető utat is (magyarázat és indoklás nélkül). A VI. fejezetben - melynek címe $A z$ arányos osztás -, megjelenik a számtani sorozat általános tagjára vonatkozó számítási mód is, ami azonban bonyolult arányos osztáson alapuló módszerrel történik.

JANG HUJ (XIII. sz.) művei sajnos csak részben maradtak fenn. Ö többek között magasabb fokú egyenleteket oldott meg a Horner-módszerrel és megadta a páratlan számok összegét 1től $(2 n+1)$-ig. Nála is megtalálhatjuk a négyzetszámok és a háromszögszámok összegét is. Ez utóbbi: $1+3+6+\ldots+\frac{n(n+1)}{2}=\frac{n(n+1)(n+2)}{6}$.

CSU SI-CSIE (1270?-1330?) egyebek mellett sokat foglalkozott a sorozatokkal is (lásd [9] 343-344. o.). A Sze jüan jü csien (A négy elem jáspis tükre) címü munkájában szerepel az első $n$ pozitív egész számnak, valamint a következő sorozat első $n$ elemének az összegképlete:

$1+8+30+80+\ldots+\frac{n^{2}(n+1)(n+2)}{1 \cdot 2 \cdot 3}=\frac{n(n+1)(n+2)(n+3)(4 n+1)}{5 !}$. 
Könyvéből az is kitünik, hogy a középkori kínai matematikusok ismerték az első $n$ négyzetszám összegképletét is (2.5. ábra):

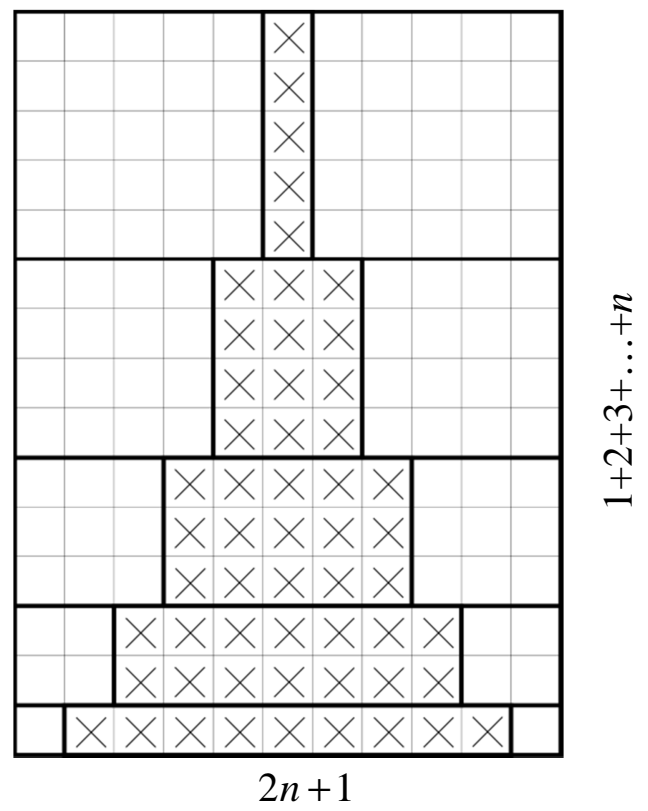

$$
3\left(1^{2}+2^{2}+3^{2}+\ldots+n^{2}\right)=(2 n+1)(1+2+3+\ldots+n)
$$

\section{5. ábra}

Az ókori és középkori hindu matematikáról fő jellegzetességként elmondható, hogy a kor tudósai az algebrai módszereket jelentős mértékben fejlesztették, föleg az egyenletmegoldási eljárásokkal. Matematikusai tisztában voltak a számtani sorozat összegzésével, meg tudták határozni az első $n$ pozitív egész szám négyzetösszegét, és ismerték a Pascal-háromszöget is.

ÁRJABHATTA (476-550?) neves indiai matematikus és csillagász Árjabhatija címü müvében kitér a számtani sorozatokra, hoz példát az összeg és az elemek számának meghatározására is. Ezenkívül megtalálhatóak nála az első $n$ négyzetszám, illetve köbszám összegzésére vonatkozó összefüggések is.

ÁCSÁRJA BHÁSZKARA (1114-1185?) egy nagy összefoglaló művet írt Sziddhánta Sirómani (A csillagászat koronája) címen, mely négy részből áll. Az első rész önálló münek is tekinthető, és Lilávati (Elbüvölö) a címe. Ennek feladatai felölelik a mértékegységek ismertetését, az egész és törtszámokkal való müveleti szabályokat a négyzetgyökvonásig bezárólag, valamint a sorozatok összegzését is.

A középkori arab-perzsa matematika sajátos algebrai karakterü volt. Ennek az algebrának további jellemzője, hogy geometriai módszerekkel bizonyít és numerikus példákkal szemléltet. Az arab-perzsa algebrában a görög elméleti geometriai és a hindu-kínai gyakorlatias irányzatok összeolvadását láthatjuk.

AL-KARADZSI ABU-BAKR MUHAMMAD IBN AL-HASZAN (953-1029) bagdadi perzsa matematikus egy nagy aritmetikai tárgyú tanulmánya az Egy megfelelö könyv az aritmetika tudományáról. Ebben a munkájában foglalkozott bizonyos sorozatok első $n$ elemének az összegzésével, nevezetesen a négyzet- és a köbszámok esetével. 
Az alábbi négyzet (2.6. ábra) területét két módon számította ki, így igazolta, hogy $1^{3}+2^{3}+3^{3}+\ldots+10^{3}=(1+2+3+\ldots+10)^{2}$, majd ebből általánosított (lásd [46] 5. o.).

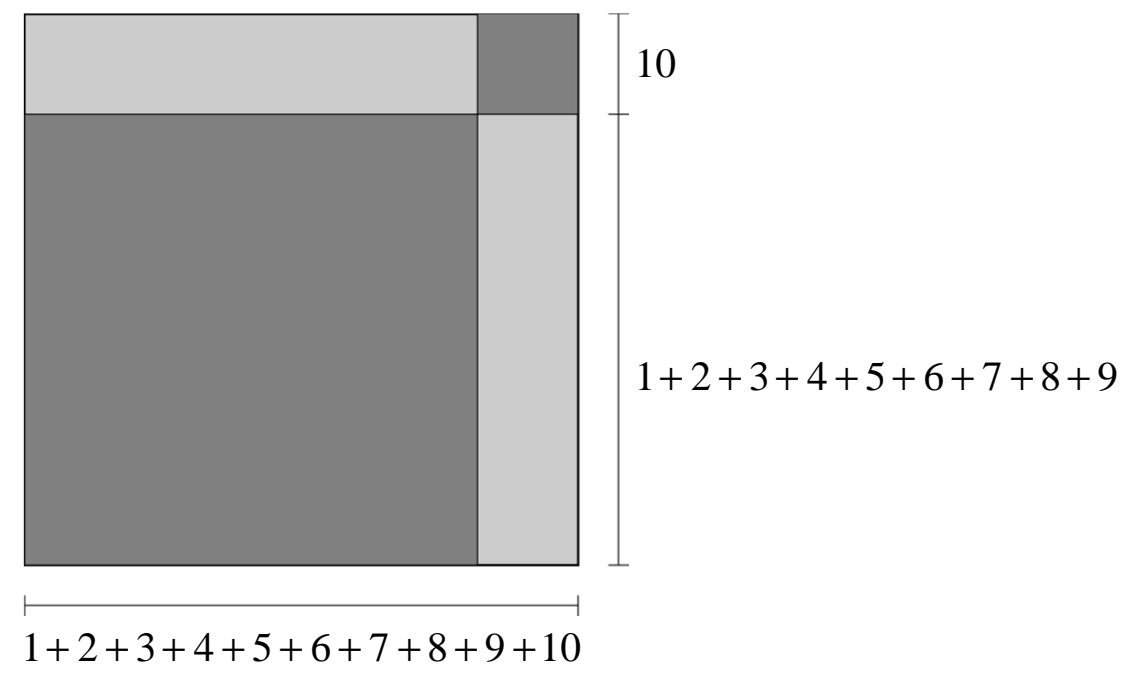

2.6. ábra

ABU ALI AL-HASAN IBN AL-HASAN IBN AL-HAYTHAM (ALHAZEN) (965-1039) orvostudománnyal is foglalkozó matematikus és fizikus volt. Optika címü könyvében egyebek között foglalkozik az első $n$ pozitív egész szám második, harmadik és negyedik hatványainak összegével. A négyzetösszeg kiszámításához egy diagramot használt (2.7. ábra), amely az alábbi összefüggés leírására szolgált: $(4+1) \cdot \sum_{i=1}^{4} i=\sum_{i=1}^{4} i^{2}+\sum_{k=1}^{4} \sum_{i=1}^{k} i$ (lásd [46] 6. o.).

\begin{tabular}{|c|c|c|c|}
\hline \multicolumn{4}{|c|}{$1+2+3+4$} \\
\hline \multicolumn{3}{|c|}{$1+2+3$} & \multirow{4}{*}{$4^{2}$} \\
\hline & +2 & \multirow{3}{*}{$3^{2}$} & \\
\hline 1 & \multirow{2}{*}{$2^{2}$} & & \\
\hline $1^{2}$ & & & \\
\hline 1 & 2 & 3 & 4 \\
\hline
\end{tabular}

A téglalap területét kétféleképpen kiszámolva jut el az első négy pozitív egész négyzetösszegéhez. A 4 helyébe $n$-et írva megkapjuk azt az összefüggést, amivel az $S_{2}$-t felírhatjuk. Al-Haytham ténylegesen $n=4$-et használta művében, azután pedig szavakkal írta le az általános eredményt. Ezek után hasonló gondolatmenettel élt a harmadik és a negyedik hatványok esetére.

A középkori Európából említést érdemel LEVI BEN GERSON (1288-1344), aki az Alhazenéhez hasonló eljárással bizonyította az $(1+2+3+\ldots+n)^{2}=1^{3}+2^{3}+3^{3}+\ldots+n^{3}$ összefüggést. 
LUCA PACIOLI (1445-1517) fő müve a Summa de arithmetica, geometria proportioni et proportionalita (Az aritmetika, a geometria, az arányok és arányosságok summázata) 1494ben jelent meg Velencében. A könyv algebrai részének van olyan egyenletmegoldása, amely megkívánja a köbszámok összegzését is (lásd [9] 479-482. o.). A megoldandó egyenlet az $(1+2+3+\ldots+x)+\left(1^{3}+2^{3}+3^{3}+\ldots+x^{3}\right)=20400$, amelyből a megoldás során az alábbi egyenlethez jutunk: $\frac{x(x+1)}{2}+\left[\frac{x(x+1)}{2}\right]^{2}=20400$. Innen a kijelölt müveletek elvégzése után az $x^{2}+x+1=\sqrt{81601}$ másodfokú egyenletet kapjuk.

Az első $n$ pozitív egész szám $p$-edik hatványösszege sokat foglalkoztatta a 16-17. század kutatóit is. Az angol THOMAS HARRIOT (1560-1621), a német JOHANN FAULHABER (1580-1635), a francia PIERRE DE FERMAT (1601-1665) és a szintén francia BLAISE PASCAL (1623-1662) fontos szerepet játszottak a kutatás fejlődésében.

Harriot sohasem adta ki matematikai, illetve tudományos munkáit, de fennmaradt utána több mint 5000 kézirat különböző témákkal kapcsolatban. Ő volt az első, aki matematikai szimbólumokkal írt fel hatványösszegekre vonatkozó összefüggéseket, azonban tette mindezt csak a negyedik hatványig.

Faulhabernek sikerült messzebbre jutni, mint elötte bárkinek. Egy 1614-ben megjelent müvében a hetedik hatványig, majd az 1617-ben kiadottban pedig a tizenkettedik hatványig írta fel a hatványösszegeket. Az 1631-es Academia Algebrae című müvében megadta az első $n$ pozitív egész hatványösszegeit a tizenharmadiktól a tizenhetedik hatványig, az $n$ és az $\frac{n(n+1)}{2}$ segítségével. Igaz ugyan, hogy megadta az első 17 kitevőre a pontos $S_{p}$ hatványösszegeket, de nem sikerült általános formulát adnia ezek kiszámítására.

Akárcsak Harriot, Fermat sem publikálta tudományos eredményeit, de más matematikusokkal történő levelezéseiből, illetve saját feljegyzéseiből fennmaradt több értékes matematikai észrevétele. Például biztosan ismerte a hatványösszegeket a negyedik hatványig, hiszen az egyik ilyen levelében szerepel a következő mondat: „, ha a legnagyobb szám négyszereséhez kettöt adva megszorozzuk a háromszögszám négyzetét, és a szorzatból kivonjuk az egyéni számok négyzeteinek összegét, megkapjuk a negyedik hatványok összegének ötszörösét" (lásd [46] 9. o.). Mai jelöléssel ez $(4 n+2) \cdot S_{1}^{2}-S_{2}=5 \cdot S_{4}$.

Egy 1636-os levelében Fermat a hatványok összegzésére szolgáló képlet megtalálásának problémáját „talán minden aritmetika legszebb problémájának” nevezte, és kitalált egy - a figurális számokat használó - rekurzív megoldást (lásd [27] 4. o.):

Az utolsó szám megszorozva a következö nagyobb számmal duplája a kollaterális háromszögnek;

az utolsó szám megszorozva a következö nagyobb számhoz tartozó háromszögszámmal háromszorosa a kollaterális gúlának;

és így tovább végtelenül ugyanígy.

Bár Pascal összeköttetésben volt (levelezett) Fermat-val, a két tudós valószínűleg nem osztotta meg egymással a saját eredményeit a hatványösszegekre vonatkozóan. Pascal megközelítései meglehetősen különböztek Fermat-éitól. A híres Traité $d u$ Triangle Aritmétique (Értekezés az aritmetikai háromszögröl) 1665-ben kiadott művében Pascal szavakban írt le általános szabályt egy számtani sorozat első $n$ tagjának hatványösszegére, melynek speciális alesete az első $n$ pozitív egész szám hatványösszege. 
Pascalnak sikerült rekurziós összefüggést felállítania az $S_{1}, S_{2}, \ldots, S_{p}$ hatványösszegek között, az alábbiak szerint:

$$
(n+1)^{p+1}-(n+1)=\left(\begin{array}{c}
p+1 \\
1
\end{array}\right) \cdot S_{1}+\left(\begin{array}{c}
p+1 \\
2
\end{array}\right) \cdot S_{2}+\ldots+\left(\begin{array}{c}
p+1 \\
p-1
\end{array}\right) \cdot S_{p-1}+\left(\begin{array}{c}
p+1 \\
p
\end{array}\right) \cdot S_{p} .
$$

Ez a rekurziós összefüggés a legismertebb és leggyakrabban használt formula az $S_{p}$ kiszámítására.

JOHN WALLIS (1616-1703) az Arithmica infinitorum (A végtelenek aritmetikája) címü 1655-ben megjelent müvében $k=9$-ig kiszámította a $\frac{0^{k}+1^{k}+2^{k}+3^{k}+\ldots+n^{k}}{n^{k}+n^{k}+n^{k}+n^{k}+\ldots+n^{k}}$ arányt, majd általánosságban ki is mondta, hogy ez az arány $\frac{1}{k+1}$, ami pedig megfelel a későbbi $\int_{0}^{1} x^{k} d x=\frac{1}{k+1}$ határozott integrál értékének.

A svájci JACOB BERNOULLI (1654-1705) szívesen foglalkozott a figurális számok, illetve ezek reciprokainak sorozataival. Felhasználva a feltételezések szerint Fermat-nak tulajdonított módszert, sikerült egy nem rekurzión alapuló összefüggést felírnia a pozitív egészek hatványösszegeire. Az ő nevéhez füződik az $S_{p}$ felírása minden kitevőre az alábbi módon:

$$
S_{p}=\frac{1}{p+1} \cdot \sum_{k=0}^{p}\left(\begin{array}{c}
p+1 \\
k
\end{array}\right) \cdot B_{k} \cdot(n+1)^{p+1-k}
$$

ahol az összefüggésben szereplő $B_{0}, B_{1}, B_{2}, \ldots$ konstansokat (Abraham Moivre javaslata nyomán) Bernoulli-számoknak nevezzük. Bernoulli eredményét halála után publikálták az Ars Conjectandi-ban 1713-ban. A Bernoulli-féle összefüggés a leghasználhatóbb és legáltalánosabb formula jelenleg is, amellyel a hatványösszeg kiszámítása sokkal egyszerübbé vált.

Végeredményben: a hatványösszegek problematikája - mint fentebb leírtuk - több száz éven át foglalkoztatta a matematikusokat. Az antikvitás kora óta az egymástól elszigetelten müködő, különböző helyeken és időben élt tudósok számos szóbeli leírást adtak az első $n$ pozitív egész szám összegére, négyzetösszegére és köbeik összegére. A 10. és 11. század kezdetére már léteztek általános módszerek ezek kiszámítására. Azonban mivel ezek az ismeretek csak szavakkal voltak leírva és a magasabb hatványokhoz szükség volt a megelőző hatványok összegeinek ismeretére, a gyakorlatban nem készültek formulák a magasabb kitevők esetére. Thomas Harriot volt az első, aki matematikai szimbólumokkal operálva a negyedik hatványig formulákat adott. Johann Faulhaber - szimbolikus jelöléseket használva már eljutott a 17. hatványig. Blaise Pascalnak sikerült rekurziós összefüggést felállítania az $S_{1}, S_{2}, \ldots, S_{p}$ hatványösszegek között. Végül is történetileg Jakob Bernoulli volt az első, aki általános képletet adott a hatványösszegek kiszámítására. 


\section{Rekurziós módszerek}

Matematikai problémák megoldása sokszor vezet rekurzióra. A rekurziók esetén elönyös lehet az, hogy a rekurziós összefüggés felírásával „,könnyen” előállítható egy tag a megelőző tagok segítségével. Épp ezért bizonyos esetekben ezen eljárások viszonylag egyszerüen programozhatóak, s a számítógép müveleti gyorsaságának kihasználásával messzire eljuthatunk a konkrét számításokban. Ugyanakkor pontosan ebben áll a módszer hátránya is, hiszen egy tetszőleges tag kiszámításához ismernünk kell nem csupán a rekurziós formulát, hanem az öt megelőző tagot (tagokat) is.

A hatványösszegek kiszámításához - mint ebben a fejezetben látható lesz majd - kiválóan felhasználhatók a rekurziók. Többféle gondolkodási úton is rekurzióra vezető formulákat tudunk előállítani. Ezek során különböző módokon jutunk el a rekurziós összefüggéshez, viszont a képletben szereplő együtthatókat más-más úton kell kiszámolni. A fejezetben öt rekurziós módszer kerül bemutatásra.

\subsection{Mátrixos (táblázatos elrendezésü) módszer}

Az első módszer használatánál nagy könnyebbség, hogy ehhez nem szükségesek sem kombinatorikai ismeretek, sem pedig kombinatorikai eszközök. A mátrixaritmetikai alapismeretek segítséget nyújtanak ugyan, de - mint majd látni fogjuk - lényegében ezek ismerete sem szükségszerü. Olyannyira nem, hogy a „mátrix” szó helyett a „táblázat” megnevezést is használhatjuk.

A ismertetendő módszer lényege, hogy egy adott mátrix elemeit különböző csoportosításokban összegezzük és így jutunk el a kívánt rekurzióhoz.

\subsubsection{Rekurziós összefüggés az első módszer segítségével}

Az alább kifejtésre kerülő módszer tárgyalása előtt először ismerkedjünk meg néhány mátrixaritmetikai alapfogalommal.

Egy $n x n$-es négyzetes (kvadratikus) mátrix esetén az $n$-et a mátrix rendjének nevezzük. Az $n$ edrendü $A$ mátrix $a_{i i}(i=1,2, \ldots, n)$ elemei alkotják a mátrix fóátlóját (fódiagonálisát). Azokat a speciális négyzetes mátrixokat, amelyekben a fóátlón kívül álló elemek mindegyike 0 , átlós (diagonális) mátrixoknak nevezzük. Háromszög- vagy trianguláris mátrixoknak nevezzük az olyan kvadratikus mátrixokat, amelyekben vagy a főátló feletti, vagy a főátló alatti elemek mind nullák. Az első esetben alsó háromszögmátrixról, a másodikban pedig felső háromszögmátrixról beszélünk.

Rátérve a vizsgálandó módszerre a kívánt rekurziós összefüggés felírásához mindenekelött vezessük be a következő jelölést:

$$
S_{k ; p}=1^{p}+2^{p}+3^{p}+\ldots+k^{p}
$$

ahol $p=0 ; 1 ; 2 ; 3 ; \ldots$ és $k=1 ; 2 ; 3 ; \ldots$. 
Az $S_{k ; 0}$ kiszámításával nem foglalkozunk külön, hiszen könnyen belátható hogy $S_{k ; 0}=k$.

Világos az is, hogy $S_{n ; p}=1^{p}+2^{p}+3^{p}+\ldots+n^{p}=S_{p}$.

Tekintsük a következő $n x n$-es négyzetes mátrixot:

$$
M=\left[\begin{array}{ccccc}
1^{p-1} & 2^{p-1} & 3^{p-1} & \ldots & n^{p-1} \\
1^{p-1} & 2^{p-1} & 3^{p-1} & \cdots & n^{p-1} \\
1^{p-1} & 2^{p-1} & 3^{p-1} & \cdots & n^{p-1} \\
--- & --- & --- & --- & --- \\
1^{p-1} & 2^{p-1} & 3^{p-1} & \ldots & n^{p-1}
\end{array}\right]
$$

Ezek után koncentráljunk az $S_{p}$ hatványösszeget megadó rekurziós összefüggés meghatározására! E célból kétféleképpen írjuk fel az $M$ elemeinek összegét.

Először, soronként összegezzük az $M$ elemeit, s ekkor adódik, hogy:

$$
n \cdot\left(1^{p-1}+2^{p-1}+3^{p-1}+\ldots+n^{p-1}\right)=n \cdot S_{p-1} .
$$

A másik összegzéshez tekintsük a következő mátrixokat:

- legyen $M_{1}$ az $M$-hez rendelt felső háromszögmátrix,

- hasonlóképpen legyen $M_{2}$ az $M$-hez rendelt alsó háromszögmátrix,

- míg $M_{3}$ az $M$-hez rendelt diagonális mátrix.

Az $M_{1}$ mátrix elemeit oszloponként összegezve kapjuk, hogy:

$$
1 \cdot 1^{p-1}+2 \cdot 2^{p-1}+3 \cdot 3^{p-1}+\ldots+n \cdot n^{p-1}=1^{p}+2^{p}+3^{p}+\ldots+n^{p}=S_{p} .
$$

Az $M_{2}$ mátrix elemeit soronként összegezve:

$$
\begin{aligned}
& 1^{p-1}+\left(1^{p-1}+2^{p-1}\right)+\left(1^{p-1}+2^{p-1}+3^{p-1}\right)+\ldots+\left(1^{p-1}+2^{p-1}+3^{p-1}+\ldots+n^{p-1}\right)= \\
& =S_{1 ; p-1}+S_{2 ; p-1}+S_{3 ; p-1}+\ldots+S_{n ; p-1}=\sum_{k=1}^{n} S_{k ; p-1} .
\end{aligned}
$$

Végül az $M_{3}$ mátrix elemeinek az összege:

$$
1^{p-1}+2^{p-1}+3^{p-1}+\ldots+n^{p-1}=S_{p-1} .
$$

Felhasználva, hogy az $M=M_{1}+M_{2}-M_{3}$, a (3.1.2)-(3.1.5) összefüggések alapján felírható:

$$
n \cdot S_{p-1}=S_{p}+\sum_{k=1}^{n} S_{k ; p-1}-S_{p-1}
$$

melyet átrendezve az alábbi összefüggést kapjuk:

$$
S_{p}=(n+1) \cdot S_{p-1}-\sum_{k=1}^{n} S_{k ; p-1} .
$$

Belátható, hogy az $S_{p}$ kiszámítása az $S_{1}, S_{2}, \ldots, S_{p-1}$ eredményeinek felhasználásával történik, azaz akármilyen $p$-re is akarjuk meghatározni a hatványösszegeket „,nem spórolható meg” az összegnek a megelőző $p$-kre történő kiszámítása. 


\subsubsection{Speciális esetek a kapott rekurziós összefüggésre}

Ha $p=1$, akkor a (3.1.6) összefüggés alapján

$S_{1}=(n+1) \cdot S_{0}-\sum_{k=1}^{n} S_{k ; 0}=(n+1) n-\sum_{k=1}^{n} k=(n+1) n-S_{1}$. Ebböl kapjuk, hogy $2 \cdot S_{1}=n(n+1)$, ahonnan $S_{1}=\frac{n(n+1)}{2}$.

Tehát $S_{1}$ esetén, a középiskolai tananyagban is szereplö, az első $n$ pozitív egész szám összegére vonatkozó ismert összefüggést kapjuk. Jelesül:

$$
S_{1}=1+2+3+\ldots+n=\frac{n(n+1)}{2} .
$$

Ha $p=2$, akkor a (3.1.6) összefüggést alkalmazva

$$
\begin{aligned}
& S_{2}=(n+1) \cdot S_{1}-\sum_{k=1}^{n} S_{k ; 1}=(n+1) \cdot \frac{n(n+1)}{2}-\sum_{k=1}^{n} \frac{k(k+1)}{2}= \\
& =\frac{n(n+1)^{2}}{2}-\frac{1}{2} \cdot \sum_{k=1}^{n}\left(k^{2}+k\right)=\frac{n(n+1)^{2}}{2}-\frac{1}{2} \cdot\left(\sum_{k=1}^{n} k^{2}+\sum_{k=1}^{n} k\right)= \\
& =\frac{n(n+1)^{2}}{4}-\frac{1}{2} \cdot S_{2}-\frac{1}{2} \cdot S_{1} .
\end{aligned}
$$

Ezt átrendezve, majd felhasználva az $S_{1}$-re kapott eredményt, adódik, hogy

$$
\begin{aligned}
& \frac{3}{2} \cdot S_{2}=\frac{n(n+1)^{2}}{2}-\frac{1}{2} \cdot S_{1}=\frac{n(n+1)^{2}}{2}-\frac{n(n+1)}{4}=\frac{n(n+1)}{4} \cdot(2 n+2-1)= \\
& =\frac{n(n+1)(2 n+1)}{4},
\end{aligned}
$$

ahonnan, az egyenlőség bal- és jobboldalát $\frac{3}{2}$-del osztva, $S_{2}=\frac{n(n+1)(2 n+1)}{6}$.

A kapott eredmény szintén „ismerős” lehet. A kétszintű érettségit megelőző érettségi esetén az egyik „elméleti” tétel épp az első $n$ pozitív egész szám négyzetösszegére vonatkozó összefüggés bizonyítása volt, azaz hogy teljesül

$$
S_{2}=1^{2}+2^{2}+3^{2}+\ldots+n^{2}=\frac{n(n+1)(2 n+1)}{6} .
$$

Ha $p=3$, akkor a (3.1.6) összefüggés szerint

$$
\begin{aligned}
& S_{3}=(n+1) \cdot S_{2}-\sum_{k=1}^{n} S_{k ; 2}=(n+1) \cdot \frac{n(n+1)(2 n+1)}{6}-\sum_{k=1}^{n} \frac{k(k+1)(2 k+1)}{6}= \\
& =\frac{n(n+1)^{2}(2 n+1)}{6}-\frac{1}{6} \cdot \sum_{k=1}^{n}\left(2 k^{3}+3 k^{2}+k\right)= \\
& =\frac{n(n+1)^{2}(2 n+1)}{6}-\frac{1}{6} \cdot\left(2 \cdot \sum_{k=1}^{n} k^{3}+3 \cdot \sum_{k=1}^{n} k^{2}+\sum_{k=1}^{n} k\right)=
\end{aligned}
$$


$=\frac{n(n+1)^{2}(2 n+1)}{6}-\frac{1}{3} \cdot S_{3}-\frac{1}{2} \cdot S_{2}-\frac{1}{6} \cdot S_{1}$.

Átrendezve, majd felhasználva az $S_{1}$ és $S_{2}$ hatványösszegekre kapott eredményeket,

$\frac{4}{3} \cdot S_{3}=\frac{n(n+1)^{2}(2 n+1)}{6}-\frac{1}{2} \cdot S_{2}-\frac{1}{6} \cdot S_{1}=\frac{n(n+1)^{2}(2 n+1)}{6}-\frac{n(n+1)(2 n+1)}{12}-\frac{n(n+1)}{12}=$
$=\frac{n(n+1)}{12} \cdot\left(4 n^{2}+6 n+2-2 n-1-1\right)=\frac{n(n+1)}{12} \cdot\left(4 n^{2}+4 n\right)=\frac{n(n+1)}{3} \cdot n(n+1)$,

ahonnan, $\frac{4}{3}$-dal végigosztva, $S_{3}=\frac{n^{2}(n+1)^{2}}{4}$.

Tehát:

$$
S_{3}=1^{3}+2^{3}+3^{3}+\ldots+n^{3}=\frac{n^{2}(n+1)^{2}}{4} .
$$

Ha $p=4$, akkor ismételten a (3.1.6) összefüggés alkalmazásával

$$
\begin{aligned}
& S_{4}=(n+1) \cdot S_{3}-\sum_{k=1}^{n} S_{k ; 3}=(n+1) \cdot \frac{n^{2}(n+1)^{2}}{4}-\sum_{k=1}^{n} \frac{k^{2}(k+1)^{2}}{4}= \\
& =\frac{n^{2}(n+1)^{3}}{4}-\frac{1}{4} \cdot \sum_{k=1}^{n}\left(k^{4}+2 k^{3}+k^{2}\right)=\frac{n^{2}(n+1)^{3}}{4}-\frac{1}{4} \cdot\left(\sum_{k=1}^{n} k^{4}+2 \cdot \sum_{k=1}^{n} k^{3}+\sum_{k=1}^{n} k^{2}\right)= \\
& =\frac{n^{2}(n+1)^{3}}{4}-\frac{1}{4} \cdot S_{4}-\frac{1}{2} \cdot S_{3}-\frac{1}{4} \cdot S_{2} .
\end{aligned}
$$

Átrendezve, majd felhasználva az $S_{2}$ és az $S_{3}$ hatványösszegekre kapott eredményeket,

$$
\begin{aligned}
& \frac{5}{4} \cdot S_{4}=\frac{n^{2}(n+1)^{3}}{4}-\frac{1}{2} \cdot S_{3}-\frac{1}{4} \cdot S_{2}=\frac{n^{2}(n+1)^{3}}{4}-\frac{n^{2}(n+1)^{2}}{8}-\frac{n(n+1)(2 n+1)}{24}= \\
& =\frac{n^{2}(n+1)^{2}}{8} \cdot(2 n+2-1)-\frac{n(n+1)(2 n+1)}{24}=\frac{n^{2}(n+1)^{2}(2 n+1)}{8}-\frac{n(n+1)(2 n+1)}{24}= \\
& =\frac{n(n+1)(2 n+1)}{24} \cdot[3 n(n+1)-1]=\frac{n(n+1)(2 n+1)}{24} \cdot\left(3 n^{2}+3 n-1\right),
\end{aligned}
$$

ahonnan, a kapott egyenlőség bal- és jobboldalát $\frac{5}{4}$-del végigosztva, kapjuk hogy

$$
S_{4}=\frac{n(n+1)(2 n+1)\left(3 n^{2}+3 n-1\right)}{30} .
$$

Tehát:

$$
S_{4}=1^{4}+2^{4}+3^{4}+\ldots+n^{4}=\frac{n(n+1)(2 n+1)\left(3 n^{2}+3 n-1\right)}{30} .
$$


Ha $p=5$, akkor újból a (3.1.6) összefüggést felhasználva

$$
\begin{aligned}
& S_{5}=(n+1) \cdot S_{4}-\sum_{k=1}^{n} S_{k ; 4}= \\
& =(n+1) \cdot \frac{n(n+1)(2 n+1)\left(3 n^{2}+3 n-1\right)}{30}-\sum_{k=1}^{n} \frac{k(k+1)(2 k+1)\left(3 k^{2}+3 k-1\right)}{30}= \\
& =\frac{n(n+1)^{2}(2 n+1)\left(3 n^{2}+3 n-1\right)}{30}-\frac{1}{30} \cdot \sum_{k=1}^{n}\left(6 k^{5}+15 k^{4}+10 k^{3}-k\right)= \\
& =\frac{n(n+1)^{2}(2 n+1)\left(3 n^{2}+3 n-1\right)}{30}-\frac{1}{30} \cdot\left(6 \cdot \sum_{k=1}^{n} k^{5}+15 \cdot \sum_{k=1}^{n} k^{4}+10 \cdot \sum_{k=1}^{n} k^{3}-\sum_{k=1}^{n} k\right)= \\
& =\frac{n(n+1)^{2}(2 n+1)\left(3 n^{2}+3 n-1\right)}{30}-\frac{1}{5} \cdot S_{5}-\frac{1}{2} \cdot S_{4}-\frac{1}{3} \cdot S_{3}+\frac{1}{30} \cdot S_{1} .
\end{aligned}
$$

Átrendezve, illetve az $S_{1}, S_{3}$ és $S_{4}$ eredményeinek felhasználásával kapjuk, hogy

$$
\begin{aligned}
& \frac{6}{5} \cdot S_{5}=\frac{n(n+1)^{2}(2 n+1)\left(3 n^{2}+3 n-1\right)}{30}-\frac{1}{2} \cdot S_{4}-\frac{1}{3} \cdot S_{3}+\frac{1}{30} \cdot S_{1}= \\
& =\frac{n(n+1)^{2}(2 n+1)\left(3 n^{2}+3 n-1\right)}{30}-\frac{n(n+1)(2 n+1)\left(3 n^{2}+3 n-1\right)}{60}-\frac{n^{2}(n+1)^{2}}{12}+\frac{n(n+1)}{60}= \\
& =\frac{n(n+1)}{60} \cdot\left[2(n+1)(2 n+1)\left(3 n^{2}+3 n-1\right)-(2 n+1)\left(3 n^{2}+3 n-1\right)-5 n(n+1)+1\right]= \\
& =\frac{n(n+1)}{60} \cdot\left(12 n^{4}+24 n^{3}+6 n^{2}-6 n\right)=\frac{n^{2}(n+1)}{10} \cdot\left(2 n^{3}+4 n^{2}+n-1\right)= \\
& =\frac{n^{2}(n+1)}{10} \cdot(n+1)\left(2 n^{2}+2 n-1\right),
\end{aligned}
$$

ahonnan, $\frac{6}{5}$-del végigosztva, $S_{5}=\frac{n^{2}(n+1)^{2}\left(2 n^{2}+2 n-1\right)}{12}$.

Tehát:

$$
S_{5}=1^{5}+2^{5}+3^{5}+\ldots+n^{5}=\frac{n^{2}(n+1)^{2}\left(2 n^{2}+2 n-1\right)}{12} .
$$

Nyilvánvaló, hogy a bemutatottakhoz hasonlóan írhatók fel a megfelelő összefüggések a $p \geq 6$ esetekben is, természetesen felhasználva az adott $p$-nél kisebb pozitív egész számok esetén kapott eredményeket.

\section{$\underline{1 .}$ Megjegyzés}

A további fejezetekben bemutatásra kerülő módszerek esetén az $S_{1}$ és $S_{2}$ összegeket „közismertségük” miatt már nem fogjuk felírni, mindössze az $S_{1}$-re és az $S_{2}$-re kapott eredményeket fogjuk felhasználni a számításainkban. 


\section{Megjegyzés}

Szemléletes bizonyítás az $S_{1}$ kiszámítására (3.1.1. ábra):

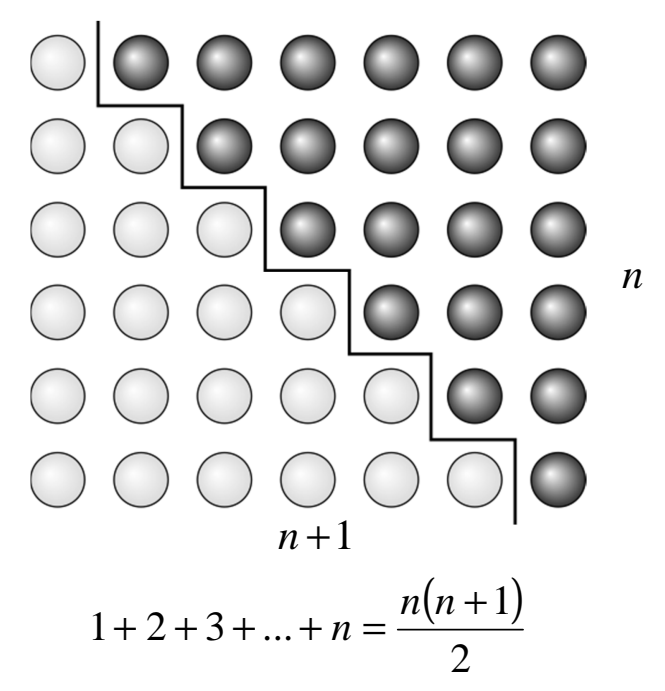

3.1.1. ábra

Szemléletes bizonyítás az $S_{2}$ kiszámítására (3.1.2. ábra):
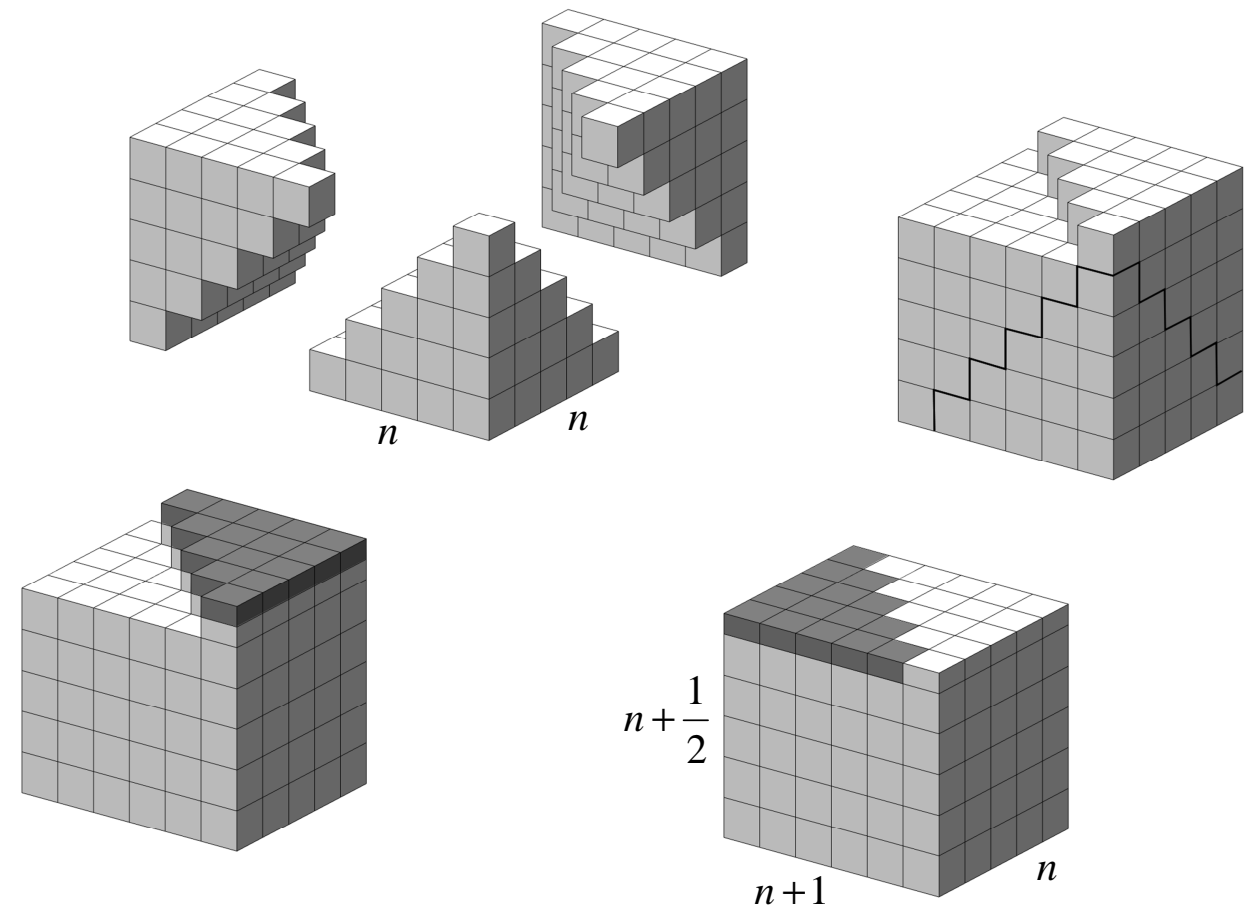

$$
1^{2}+2^{2}+3^{2}+\ldots+n^{2}=\frac{1}{3} n(n+1)\left(n+\frac{1}{2}\right)
$$

\subsection{2. ábra}


Az előzőekben kiszámított $S_{i}$ összegek között több különböző, érdekes kapcsolat teremthető.

Ezek közül néhány példaként:

$$
\begin{array}{ll}
3 \cdot S_{2}=(2 n+1) \cdot S_{1} & \\
S_{3}=S_{1}^{2} & \text { (Nikomakhosz) } \\
5 \cdot S_{4}=(4 n+2) \cdot S_{3}-S_{2} & \text { (Fermat) } \\
S_{5}=S_{3} \cdot\left(4 \cdot S_{1}-1\right) &
\end{array}
$$

Az összefüggések bizonyítása egyszerü behelyettesítéssel történik.

Felhasználva a további, $p \geq 6$ esetekben kiszámított eredményeket is, nyilvánvalóan újabb összefüggések készíthetők ezek segítségével.

\subsubsection{A „mátrixos” módszer alkalmazása alternáló összeg esetére}

Ugyancsak érdekes matematikai feladat az első $n$ pozitív természetes szám $p$-edik hatványa „,váltakozó előjelü összegének” kiszámítása. Ennek meghatározására először egy „klasszikus” eljárást ismertetünk, amely az első $n$ pozitív egész szám $p$-edik hatványa összegére való visszavezetésen alapszik, majd egy másik módszert is bemutatunk, amelynek gondolatmenete hasonlít a 3.1.1. fejezetben ismertetettnél, azaz az $S_{p}$ kiszámításánál megvalósítottra.

A feladatunk tehát, hogy számítsuk ki az

$$
S_{p}^{*}=1^{p}-2^{p}+3^{p}-4^{p}+\ldots+(-1)^{n-1} \cdot n^{p}=\sum_{k=1}^{n}(-1)^{k-1} \cdot k^{p}
$$

alternáló összeget, ahol $p$ természetes szám és $n$ pozitív egész.

Ennek végrehajtásánál az $S_{0}^{*}$ kiszámításával külön nem foglalkozunk, mivel könnyen belátható, hogy:

$$
S_{0}^{*}=\sum_{k=1}^{n}(-1)^{k-1}= \begin{cases}0, & \text { ha } n \text { páros } \\ 1, & \text { ha } n \text { páratlan } .\end{cases}
$$

Másképp felírva: $S_{0}^{*}=\frac{1+(-1)^{n-1}}{2}$.

Mint említettuik, a probléma egyik „klasszikus” megoldása a feladat visszavezetése az első $n$ pozitív egész szám $p$-edik hatványa összegének megkeresésére. Itt két esetet kell vizsgálnunk, az alábbiak szerint:

1. eset: ha $n$ páros, azaz $n=2 k$, ahol $k$ pozitív egész szám, akkor

$$
\begin{aligned}
& S_{p}^{*}=\sum_{i=1}^{2 k}(-1)^{i-1} \cdot i^{p}=1^{p}-2^{p}+3^{p}-4^{p}+\ldots+(2 k-1)^{p}-(2 k)^{p}= \\
& =1^{p}+2^{p}+3^{p}+\ldots+(2 k-1)^{p}+(2 k)^{p}-2 \cdot\left[2^{p}+4^{p}+\ldots+(2 k-2)^{p}+(2 k)^{p}\right]= \\
& =1^{p}+2^{p}+3^{p}+\ldots+(2 k-1)^{p}+(2 k)^{p}-2 \cdot 2^{p} \cdot\left[1^{p}+2^{p}+\ldots+(k-1)^{p}+k^{p}\right]= \\
& =\sum_{i=1}^{2 k} i^{p}-2^{p+1} \cdot \sum_{i=1}^{k} i^{p}=S_{2 k ; p}-2^{p+1} \cdot S_{k ; p}=S_{n ; p}-2^{p+1} \cdot S_{\frac{n}{2} ; p}=S_{p}-2^{p+1} \cdot S_{\frac{n}{2} ; p}
\end{aligned}
$$


ahol $S_{\frac{n}{2} ; p}$ az első $\frac{n}{2}$ pozitív egész szám $p$-edik hatványa összegét jelöli.

2. eset: ha $n$ páratlan, azaz $n=2 k+1$ alakú, ez esetben

$$
\begin{aligned}
& S_{p}^{*}=\sum_{i=1}^{2 k+1}(-1)^{i-1} \cdot i^{p}=1^{p}-2^{p}+3^{p}-\ldots-(2 k)^{p}+(2 k+1)^{p}= \\
& =1^{p}+2^{p}+3^{p}+\ldots+(2 k)^{p}+(2 k+1)^{p}-2 \cdot\left[2^{p}+4^{p}+\ldots+(2 k-2)^{p}+(2 k)^{p}\right]= \\
& =1^{p}+2^{p}+3^{p}+\ldots+(2 k)^{p}+(2 k+1)^{p}-2 \cdot 2^{p} \cdot\left[1^{p}+2^{p}+\ldots+(k-1)^{p}+k^{p}\right]= \\
& =\sum_{i=1}^{2 k+1} i^{p}-2^{p+1} \cdot \sum_{i=1}^{k} i^{p}=S_{2 k+1 ; p}-2^{p+1} \cdot S_{k ; p}=S_{n ; p}-2^{p+1} \cdot S_{\frac{n-1}{2} ; p}=S_{p}-2^{p+1} \cdot S_{\frac{n-1}{2} ; p},
\end{aligned}
$$

ahol $S_{\frac{n-1}{2} ; p}$ az első $\frac{n-1}{2}$ pozitív egész szám $p$-edik hatványa összegét jelöli.

Összefoglalva a fenti eredményeket, kapjuk hogy

$$
S_{p}^{*}=S_{p}-2^{p+1} \cdot S_{k ; p}
$$

ahol $k=\frac{n-\frac{1}{2}+(-1)^{n} \cdot \frac{1}{2}}{2}=\frac{2 n-1+(-1)^{n}}{4}$.

A feladatot meg lehet közelíteni más módon is. A következőkben egy olyan módszert mutatunk be, amelynél szintén egy rekurziós összefüggést vezetünk le, ezúttal azonban az $S_{p}^{*}$ sorozat tagjai között. Itt nagy elöny, hogy az eredményekhez nincs szükségünk az $S_{p}$ hatványösszegekre.

Tekintsük tehát a következő $n x n$-es mátrixot:

$$
\bar{M}=\left[\begin{array}{ccccc}
1^{p-1} & -2^{p-1} & 3^{p-1} & \ldots & (-1)^{n-1} \cdot n^{p-1} \\
1^{p-1} & -2^{p-1} & 3^{p-1} & \ldots & (-1)^{n-1} \cdot n^{p-1} \\
1^{p-1} & -2^{p-1} & 3^{p-1} & \ldots & (-1)^{n-1} \cdot n^{p-1} \\
--- & --- & --- & --- & --- \\
1^{p-1} & -2^{p-1} & 3^{p-1} & \ldots & (-1)^{n-1} \cdot n^{p-1}
\end{array}\right]
$$

Ha soronként összegezzük az $\bar{M}$ mátrix elemeit, akkor az elemek összege

$$
n \cdot\left[1^{p-1}-2^{p-1}+\ldots+(-1)^{n-1} \cdot n^{p-1}\right]=n \cdot S_{p-1}^{*}
$$

lesz.

Ezután tekintsük a következő mátrixokat:

- legyen $\bar{M}_{1}$ az $\bar{M}$-hez rendelt felső háromszögmátrix,

- az $\bar{M}_{2}$ az $\bar{M}$-hez rendelt alsó háromszögmátrix,

- míg $\bar{M}_{3}$ az $\bar{M}$-hez rendelt diagonális mátrix. 
Az $\bar{M}_{1}$ mátrix elemeit oszloponként összegezve kapjuk, hogy

$$
1 \cdot 1^{p-1}+2 \cdot\left(-2^{p-1}\right)+\ldots+n \cdot\left[(-1)^{n-1} \cdot n^{p-1}\right]=1^{p}-2^{p}+\ldots+(-1)^{n-1} \cdot n^{p}=S_{p}^{*} .
$$

Az $\bar{M}_{2}$ mátrix elemeit soronként összegezve:

$$
\begin{aligned}
& 1^{p-1}+\left(1^{p-1}-2^{p-1}\right)+\left(1^{p-1}-2^{p-1}+3^{p-1}\right)+\ldots+\left\lfloor 1^{p-1}-2^{p-1}+\ldots+(-1)^{n-1} \cdot n^{p-1}\right\rfloor= \\
& =S_{1 ; p-1}^{*}+S_{2 ; p-1}^{*}+\ldots+S_{n ; p-1}^{*}=\sum_{k=1}^{n} S_{k ; p-1}^{*},
\end{aligned}
$$

ahol $S_{k ; p}^{*}=1^{p}-2^{p}+\ldots+(-1)^{k-1} \cdot k^{p}$.

Végül az $\bar{M}_{3}$ mátrix elemeinek összege:

$$
1^{p-1}-2^{p-1}+\ldots+(-1)^{n-1} \cdot n^{p-1}=S_{p-1}^{*} .
$$

Felhasználva, hogy $\bar{M}=\bar{M}_{1}+\bar{M}_{2}-\bar{M}_{3}$, a (3.1.9)-(3.1.12) összefüggések alapján adódik hogy $n \cdot S_{p-1}^{*}=S_{p}^{*}+\sum_{k=1}^{n} S_{k ; p-1}^{*}-S_{p-1}^{*}$, melyet átrendezve az alábbi összefüggést kapjuk:

$$
S_{p}^{*}=(n+1) \cdot S_{p-1}^{*}-\sum_{k=1}^{n} S_{k ; p-1}^{*} .
$$

Belátható, hogy az $S_{p}^{*}$ kiszámítása az $S_{1}^{*}, S_{2}^{*}, \ldots, S_{p-1}^{*}$ eredményeinek felhasználásával történik. A mátrixos módszer tehát jól használható az alternáló összegek kiszámítására is annak minden elönyével és hátrányával együtt.

\subsubsection{Speciális esetek az alternáló összeg esetén kapott összefüggésre}

Az alábbiakban bemutatunk néhány érdekes eredményt, éspedig négy konkrét $p$ érték ( $p=1 ; 2 ; 3 ; 4)$ esetére.

Ha $p=1$, akkor a (3.1.13) összefüggés alapján

$$
\begin{aligned}
& S_{1}^{*}=(n+1) \cdot S_{0}^{*}-\sum_{k=1}^{n} S_{k ; 0}^{*}=(n+1) \cdot S_{0}^{*}-\sum_{k=1}^{n} \frac{1+(-1)^{k-1}}{2}= \\
& =(n+1) \cdot S_{0}^{*}-\frac{1}{2} \cdot\left[\sum_{k=1}^{n} 1+\sum_{k=1}^{n}(-1)^{k-1}\right]=(n+1) \cdot S_{0}^{*}-\frac{1}{2} \cdot\left(n+S_{0}^{*}\right)=\frac{2 n+1}{2} \cdot S_{0}^{*}-\frac{n}{2}= \\
& =\frac{2 n+1}{2} \cdot \frac{1+(-1)^{n-1}}{2}-\frac{n}{2}=\frac{2 n+1+(-1)^{n-1} \cdot(2 n+1)-2 n}{4}=\frac{1+(-1)^{n-1} \cdot(2 n+1)}{4} .
\end{aligned}
$$

Tehát:

$$
S_{1}^{*}=1-2+3-4+\ldots+(-1)^{n-1} \cdot n=\frac{1+(-1)^{n-1} \cdot(2 n+1)}{4} .
$$

Másképp felírva: $S_{1}^{*}= \begin{cases}\frac{n+1}{2}, & \text { ha } n \text { páratlan } \\ -\frac{n}{2}, & \text { ha } n \text { páros }\end{cases}$ 
Ha $p=2$, akkor ismét csak a (3.1.13) összefüggés alapján kaphatjuk, hogy

$$
\begin{aligned}
& S_{2}^{*}=(n+1) \cdot S_{1}^{*}-\sum_{k=1}^{n} S_{k ; 1}^{*}=(n+1) \cdot S_{1}^{*}-\sum_{k=1}^{n} \frac{1+(-1)^{k-1} \cdot(2 k+1)}{4}= \\
& =(n+1) \cdot S_{1}^{*}-\frac{1}{4} \cdot\left[\sum_{k=1}^{n} 1+2 \cdot \sum_{k=1}^{n}(-1)^{k-1} \cdot k+\sum_{k=1}^{n}(-1)^{k-1}\right]=(n+1) \cdot S_{1}^{*}-\frac{1}{4} \cdot\left(n+2 \cdot S_{1}^{*}+S_{0}^{*}\right)= \\
& =\frac{2 n+1}{2} \cdot S_{1}^{*}-\frac{1}{4} \cdot S_{0}^{*}-\frac{n}{4}=\frac{2 n+1}{2} \cdot \frac{1+(-1)^{n-1} \cdot(2 n+1)}{4}-\frac{1}{4} \cdot \frac{1+(-1)^{n-1}}{2}-\frac{n}{4}= \\
& =\frac{2 n+1+(-1)^{n-1} \cdot(2 n+1)^{2}-1-(-1)^{n-1}-2 n}{8}=\frac{(-1)^{n-1} \cdot\left(4 n^{2}+4 n+1-1\right)}{8}= \\
& =\frac{(-1)^{n-1} \cdot\left(n^{2}+n\right)}{2} .
\end{aligned}
$$

Tehát:

$$
S_{2}^{*}=1^{2}-2^{2}+3^{2}-4^{2}+\ldots+(-1)^{n-1} \cdot n^{2}=(-1)^{n-1} \cdot \frac{n(n+1)}{2} .
$$

Ha $p=3$, akkor megint a (3.1.13) összefüggést felhasználva felírható, hogy

$$
\begin{aligned}
& S_{3}^{*}=(n+1) \cdot S_{2}^{*}-\sum_{k=1}^{n} S_{k ; 2}^{*}=(n+1) \cdot S_{2}^{*}-\sum_{k=1}^{n}(-1)^{k-1} \cdot \frac{k^{2}+k}{2}= \\
& =(n+1) \cdot S_{2}^{*}-\frac{1}{2} \cdot\left[\sum_{k=1}^{n}(-1)^{k-1} \cdot k^{2}+\sum_{k=1}^{n}(-1)^{k-1} \cdot k\right]=(n+1) \cdot S_{2}^{*}-\frac{1}{2} \cdot\left(S_{2}^{*}+S_{1}^{*}\right)= \\
& =\frac{2 n+1}{2} \cdot S_{2}^{*}-\frac{1}{2} \cdot S_{1}^{*}=\frac{2 n+1}{2} \cdot \frac{(-1)^{n-1} \cdot\left(n^{2}+n\right)}{2}-\frac{1}{2} \cdot \frac{1+(-1)^{n-1} \cdot(2 n+1)}{4}= \\
& =\frac{(-1)^{n-1} \cdot(2 n+1)\left(2 n^{2}+2 n\right)-1-(-1)^{n-1} \cdot(2 n+1)}{8}=\frac{-1+(-1)^{n-1} \cdot(2 n+1)\left(2 n^{2}+2 n-1\right)}{8} .
\end{aligned}
$$

Tehát:

$$
S_{3}^{*}=1^{3}-2^{3}+3^{3}-4^{3}+\ldots+(-1)^{n-1} \cdot n^{3}=\frac{-1+(-1)^{n-1} \cdot(2 n+1)\left(2 n^{2}+2 n-1\right)}{8} .
$$

Természetesen az $S_{3}^{*}$ átírható $S_{3}^{*}=\frac{-1+(-1)^{n-1} \cdot\left(4 n^{3}+6 n^{2}-1\right)}{8}$ alakra is.

Ha $p=4$, akkor ugyancsak a (3.1.13) összefüggés alapján adódik, hogy

$$
\begin{aligned}
& S_{4}^{*}=(n+1) \cdot S_{3}^{*}-\sum_{k=1}^{n} S_{k ; 3}^{*}=(n+1) \cdot S_{3}^{*}-\sum_{k=1}^{n} \frac{-1+(-1)^{k-1} \cdot\left(4 k^{3}+6 k^{2}-1\right)}{8}= \\
& =(n+1) \cdot S_{3}^{*}-\frac{1}{8} \cdot\left[-\sum_{k=1}^{n} 1+4 \cdot \sum_{k=1}^{n}(-1)^{k-1} \cdot k^{3}+6 \cdot \sum_{k=1}^{n}(-1)^{k-1} \cdot k^{2}-\sum_{k=1}^{n}(-1)^{k-1}\right]= \\
& =(n+1) \cdot S_{3}^{*}-\frac{1}{8} \cdot\left(-n+4 \cdot S_{3}^{*}+6 \cdot S_{2}^{*}-S_{0}^{*}\right)=\frac{2 n+1}{2} \cdot S_{3}^{*}-\frac{3}{4} \cdot S_{2}^{*}+\frac{1}{8} \cdot S_{0}^{*}+\frac{n}{8}= \\
& =\frac{2 n+1}{2} \cdot \frac{-1+(-1)^{n-1} \cdot\left(4 n^{3}+6 n^{2}-1\right)}{8}-\frac{3}{4} \cdot \frac{(-1)^{n-1} \cdot\left(n^{2}+n\right)}{2}+\frac{1}{8} \cdot \frac{1+(-1)^{n-1}}{2}+\frac{n}{8}=
\end{aligned}
$$




$$
\begin{aligned}
& =\frac{-2 n-1+(-1)^{n-1} \cdot(2 n+1)\left(4 n^{3}+6 n^{2}-1\right)-(-1)^{n-1} \cdot\left(6 n^{2}+6 n\right)+1+(-1)^{n-1}+2 n}{16}= \\
& =\frac{(-1)^{n-1} \cdot\left(8 n^{4}+16 n^{3}-8 n\right)}{16}=\frac{(-1)^{n-1} \cdot n\left(n^{3}+2 n^{2}-1\right)}{2} .
\end{aligned}
$$

Tehát:

$$
S_{4}^{*}=1^{4}-2^{4}+3^{4}-4^{4}+\ldots+(-1)^{n-1} \cdot n^{4}=(-1)^{n-1} \cdot \frac{n\left(n^{3}+2 n^{2}-1\right)}{2} .
$$

Az $S_{4}^{*}$ nyilvánvalóan felírható $S_{4}^{*}=(-1)^{n-1} \cdot \frac{n(n+1)\left(n^{2}+n-1\right)}{2}$ alakban is.

\section{Megjegyzés}

Szemléletes bizonyítás az $S_{2}^{*}$ kiszámítására (3.1.3. ábra):

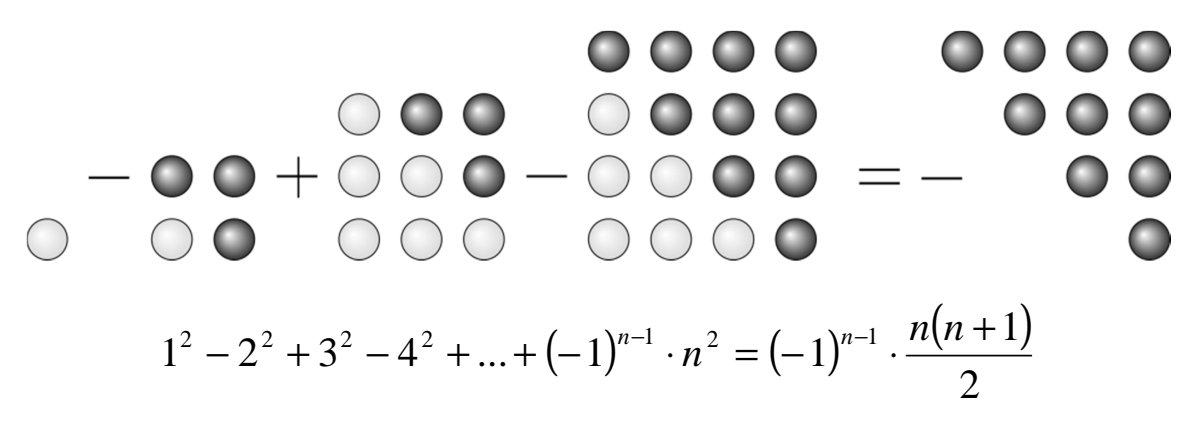

\subsection{3. ábra}

\section{Megjegyzés}

A további fejezetekben tárgyalandó módszereknél az $S_{1}^{*}$ és $S_{2}^{*}$ összegeket már nem fogjuk felírni, azonban az ottani számításainkban fel fogjuk használni a rájuk vonatkozó eredményeket.

Akárcsak az $S_{i}$ összegek esetén, az $S_{i}^{*}$ összegekre is tudunk „egyszerü” összefüggéseket felírni, sőt kapcsolatot találni bizonyos $S_{i}^{*}$ és $S_{j}$ összegek között. Például:

$$
\begin{aligned}
& 4 \cdot S_{3}^{*}=2 \cdot S_{1}^{*} \cdot\left(2 n^{2}+2 n-1\right)-n^{2}-n \\
& S_{4}^{*}=S_{2}^{*} \cdot\left(n^{2}+n-1\right) \\
& S_{1}=\left|S_{2}^{*}\right| \Rightarrow S_{1}^{2}=\left(S_{2}^{*}\right)^{2}=S_{3}
\end{aligned}
$$

Az összefüggések bizonyítása itt is egyszerü behelyettesítéssel történik.

Folytatva az $S_{p}^{*}(p \geq 5)$ összegek felírását és felhasználva a fenti eredményeket is, ezek segítségével további összefüggések készíthetők. 


\subsection{5. „Lépcsős” összegzés}

Ha egyáltalán nem akarunk mátrixaritmetikai fogalmakat használni, akkor az előző módszerhez képest szignifikánsan más úton - az ún. lépcsős módszer segítségével - is eljuthatunk a (3.1.14) táblázat alapján a (3.1.6) összefüggéshez a következőképpen:

$$
M=\begin{array}{ccccc}
\frac{1^{p-1}}{1^{p-1}} & 2^{p-1} \mid & 3^{p-1} & \ldots & n^{p-1} \\
\frac{2^{p-1}}{1^{p-1}} & \frac{2^{p-1}}{3^{p-1}} & \underline{3^{p-1}} \mid & \ldots & n^{p-1} \\
--- & --- & --- & --- & n^{p-1} \\
1^{p-1} & 2^{p-1} & 3^{p-1} & \ldots & n^{p-1}
\end{array}
$$

Az $i$-edik $(i=1 ; 2 ; \ldots ; n)$ lépcső elemei a táblázat $m_{i 1}, m_{i 2}, \ldots, m_{i i}, m_{1 i}, m_{2 i}, \ldots, m_{i-1 i} \quad$ elemei, vagy másképp fogalmazva mindazon $m_{i j}$ és $m_{j i}$ elemek, amelyekre $1 \leq j \leq i$.

Ha soronként összegezzük az $M$ táblázat elemeit, akkor az elemek összege

$$
n \cdot\left(1^{p-1}+2^{p-1}+3^{p-1}+\ldots+n^{p-1}\right)=n \cdot S_{p-1} .
$$

Ha a lépcsőzetes kiszámítást végezzük el, akkor az egy „lépcsőn” (pl. a k-adikon) lévő elemek összege:

$$
1^{p-1}+2^{p-1}+3^{p-1}+\ldots+k^{p-1}+(k-1) \cdot k^{p-1}=S_{k ; p-1}+(k-1) \cdot k^{p-1}=S_{k ; p-1}+k^{p}-k^{p-1} .
$$

Mivel $k$,végigfut” az 1,2,,.,n számokon, felírva mindegyik $k$-ra a lépcsőn lévő elemek összegét, továbbá elvégezve a $k$ szerinti összegzést, megkapjuk az $M$ táblázatban szereplő elemek összegét, amire az

$$
n \cdot S_{p-1}=\sum_{k=1}^{n}\left(S_{k ; p-1}+k^{p}-k^{p-1}\right)=\sum_{k=1}^{n} S_{k ; p-1}+\sum_{k=1}^{n} k^{p}-\sum_{k=1}^{n} k^{p-1},
$$

vagyis az $n \cdot S_{p-1}=\sum_{k=1}^{n} S_{k ; p-1}+S_{p}-S_{p-1}$ összefüggés adódik.

Ez utóbbi egyenlőséget átrendezve a már ismert (3.1.6) összefüggéshez jutunk.

Tehát:

$$
S_{p}=(n+1) \cdot S_{p-1}-\sum_{k=1}^{n} S_{k ; p-1} .
$$

Végül is a lépcsős összegzési módszer egy szép és jól használható eszköz, amelynek nagy előnye, hogy - mint láttuk - csak elemi matematikai ismeretekkel operál, nem használ mátrixaritmetikai fogalmakat és eszközöket. Így könnyen tanítható, akár középiskolai diákoknak is, gazdagítva ezzel matematikai módszertani apparátusukat.

\section{Megjegyzés}

Az $S_{p}$ kiszámítása a lépcsős módszer alkalmazásával két konkrét $p$ érték ( $p=2$ és $p=3$ ) esetében megtalálható a [38]-ban 211-212. o.

\section{$\underline{\text { 6. Megjegyzés }}$}

Analóg módon juthatunk el a (3.1.13) összefüggéshez, ha a lépcsős módszer alkalmazásával a (3.1.8) mátrixnak megfelelő táblázatból indulunk ki. 


\subsection{6. „Területes” összegzés}

A (3.1.6) összefüggés az alábbi ábra segítségével is szemléltethető (3.1.4. ábra):

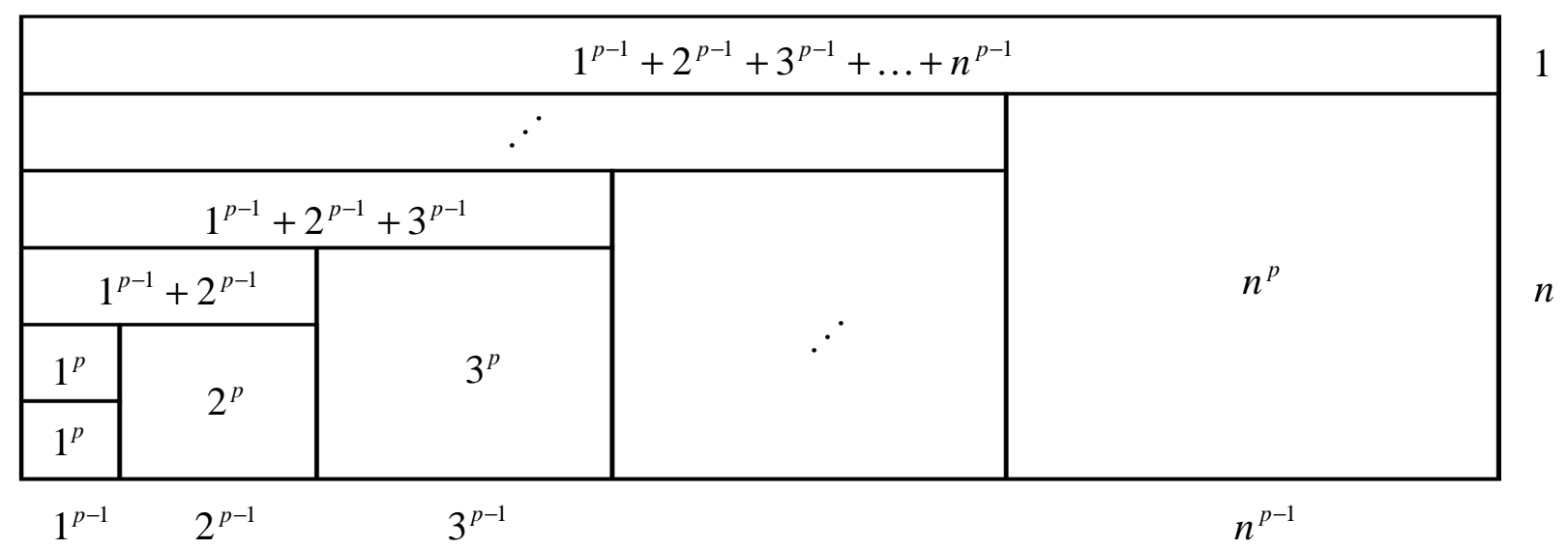

3.1.4. ábra

A téglalap területét kétféleképpen kiszámítva jutunk el a kívánt rekurzióhoz.

Egyfelől

$T=(n+1)\left(1^{p-1}+2^{p-1}+3^{p-1}+\ldots+n^{p-1}\right)=(n+1) \cdot S_{p-1}$,

másrészt pedig felhasználva, hogy $1^{p}=1^{p-1}$ kapjuk, hogy

$$
\begin{aligned}
& T=1^{p}+2^{p}+3^{p}+\ldots+n^{p}+ \\
& +1^{p-1}+\left(1^{p-1}+2^{p-1}\right)+\left(1^{p-1}+2^{p-1}+3^{p-1}\right)+\ldots+\left(1^{p-1}+2^{p-1}+3^{p-1}+\ldots+n^{p-1}\right)= \\
& =S_{p}+\left(S_{1 ; p-1}+S_{2 ; p-1}+S_{3 ; p-1}+\ldots+S_{n ; p-1}\right)=S_{p}+\sum_{k=1}^{n} S_{k ; p-1} .
\end{aligned}
$$

Innen $(n+1) \cdot S_{p-1}=S_{p}+\sum_{k=1}^{n} S_{k ; p-1}$, amit átrendezve a már ismert (3.1.6) összefüggéshez jutunk.

Tehát:

$$
S_{p}=(n+1) \cdot S_{p-1}-\sum_{k=1}^{n} S_{k ; p-1}
$$

Végső következtetésként elmondható, hogy hasznos - bizonyos rekurziós összefüggések felírására kiválóan alkalmas - metodikának bizonyul a mátrixos (táblázatos) módszer, amelynél ráadásul az összegzés kétféleképpen is elvégezhető. Ha fel akarunk használni mátrixaritmetikai alapismereteket is, akkor az adott mátrix elemeit soronként összegezve, illetve speciális mátrixok segítségével jutunk el a kívánt rekurziós összefüggésekhez, de mindez el is kerülhető az ún. „lépcsős” összegzés alkalmazásával. A fent leírt módszer ismerete, alkalmazása nagyon hasznos lehet olyan konkrét számítási és bizonyításos feladatoknál is, ahol a végeredményhez véges összegek kiszámításán keresztül jutunk el, illetve olyan feladatok esetén is alkalmazható, ahol a cél bizonyos rekurziós összefüggések felírása. 


\subsection{A rekurziós összefüggés levezetése egy speciális azonosság felhasználásával}

A formula levezetéséhez a második módszernél kombinatorikai eszközök szükségesek. Itt egy kevésbé ismert összefüggést használunk fel arra, hogy rekurziós összefüggést állapítsunk meg ([19]). A felírt azonosságba rendre behelyettesítve az 1,2,..,n természetes számokat, majd a kapott eredményeket tagonként összegezve jutunk el az $S_{p}$ hatványösszeget meghatározó rekurziós képlethez.

\subsubsection{A módszer és az előálló rekurziós összefüggés}

A kívánt formula levezetéséhez induljunk ki az alábbi összefüggésből, ahol $k$ valós szám és $p$ pozitív egész:

$$
\begin{aligned}
& (k+1) \cdot k^{p}-k \cdot(k-1)^{p}= \\
& =k^{p+1}+k^{p}-k \cdot\left[k^{p}-\left(\begin{array}{l}
p \\
1
\end{array}\right) \cdot k^{p-1}+\left(\begin{array}{l}
p \\
2
\end{array}\right) \cdot k^{p-2}-\left(\begin{array}{l}
p \\
3
\end{array}\right) \cdot k^{p-3}+\ldots+(-1)^{p} \cdot\left(\begin{array}{l}
p \\
p
\end{array}\right)\right]= \\
& =k^{p+1}+k^{p}-k^{p+1}+\left(\begin{array}{l}
p \\
1
\end{array}\right) \cdot k^{p}-\left(\begin{array}{l}
p \\
2
\end{array}\right) \cdot k^{p-1}+\left(\begin{array}{l}
p \\
3
\end{array}\right) \cdot k^{p-2}-\ldots-(-1)^{p} \cdot\left(\begin{array}{l}
p \\
p
\end{array}\right) \cdot k= \\
& =\left[1+\left(\begin{array}{l}
p \\
1
\end{array}\right)\right] \cdot k^{p}-\left(\begin{array}{l}
p \\
2
\end{array}\right) \cdot k^{p-1}+\left(\begin{array}{l}
p \\
3
\end{array}\right) \cdot k^{p-2}-\left(\begin{array}{l}
p \\
4
\end{array}\right) \cdot k^{p-3}+\ldots+(-1)^{p+1} \cdot\left(\begin{array}{l}
p \\
p
\end{array}\right) \cdot k .
\end{aligned}
$$

Mivel $\left(\begin{array}{l}p \\ 1\end{array}\right)=p$, ezért

$$
(k+1) \cdot k^{p}-k \cdot(k-1)^{p}=(p+1) \cdot k^{p}-\left(\begin{array}{l}
p \\
2
\end{array}\right) \cdot k^{p-1}+\left(\begin{array}{l}
p \\
3
\end{array}\right) \cdot k^{p-2}-\left(\begin{array}{l}
p \\
4
\end{array}\right) \cdot k^{p-3}+\ldots+(-1)^{p+1} \cdot\left(\begin{array}{l}
p \\
p
\end{array}\right) \cdot k .
$$

Ekkor

$$
\begin{aligned}
& \sum_{i=1}^{n}\left[(i+1) \cdot i^{p}-i \cdot(i-1)^{p}\right]= \\
& =\sum_{i=1}^{n}\left[(p+1) \cdot i^{p}-\left(\begin{array}{l}
p \\
2
\end{array}\right) \cdot i^{p-1}+\left(\begin{array}{l}
p \\
3
\end{array}\right) \cdot i^{p-2}-\left(\begin{array}{l}
p \\
4
\end{array}\right) \cdot i^{p-3}+\ldots+(-1)^{p+1} \cdot\left(\begin{array}{l}
p \\
p
\end{array}\right) \cdot i\right]= \\
& =(p+1) \cdot \sum_{i=1}^{n} i^{p}-\left(\begin{array}{l}
p \\
2
\end{array}\right) \cdot \sum_{i=1}^{n} i^{p-1}+\left(\begin{array}{l}
p \\
3
\end{array}\right) \cdot \sum_{i=1}^{n} i^{p-2}-\left(\begin{array}{l}
p \\
4
\end{array}\right) \cdot \sum_{i=1}^{n} i^{p-3}+\ldots+(-1)^{p+1} \cdot\left(\begin{array}{l}
p \\
p
\end{array}\right) \cdot \sum_{i=1}^{n} i .
\end{aligned}
$$

A bal oldalon egy teleszkópikus összeg található, amely az összevonások után $(n+1) n^{p}-0$ lesz, vagyis

$$
(n+1) n^{p}=(p+1) \cdot S_{p}-\left(\begin{array}{l}
p \\
2
\end{array}\right) \cdot S_{p-1}+\left(\begin{array}{l}
p \\
3
\end{array}\right) \cdot S_{p-2}-\left(\begin{array}{l}
p \\
4
\end{array}\right) \cdot S_{p-3}+\ldots+(-1)^{p+1} \cdot\left(\begin{array}{l}
p \\
p
\end{array}\right) \cdot S_{1} .
$$


Átrendezve

$$
(p+1) \cdot S_{p}=(n+1) n^{p}+\left(\begin{array}{l}
p \\
2
\end{array}\right) \cdot S_{p-1}-\left(\begin{array}{l}
p \\
3
\end{array}\right) \cdot S_{p-2}+\ldots+(-1)^{p} \cdot\left(\begin{array}{l}
p \\
p
\end{array}\right) \cdot S_{1},
$$

ahonnan

$$
S_{p}=\frac{(n+1) n^{p}+\left(\begin{array}{l}
p \\
2
\end{array}\right) \cdot S_{p-1}-\left(\begin{array}{l}
p \\
3
\end{array}\right) \cdot S_{p-2}+\ldots+(-1)^{p} \cdot\left(\begin{array}{l}
p \\
p
\end{array}\right) \cdot S_{1}}{p+1} .
$$

Látható, hogy az $S_{p}$ kiszámításához ezúttal is szükség van a megelöző $S_{1}, S_{2}, \ldots, S_{p-1}$, összegekre kapott eredményekre.

\subsubsection{A kapott összefüggés néhány konkrét esetben}

Felhasználva az $S_{1}$ és $S_{2}$ összegeket, a következőkben megállapítjuk az $S_{3}, S_{4}$ és $S_{5}$ esetén érvényes összefüggéseket.

Ha $p=3$, akkor felhasználva az $S_{1}$ és az $S_{2}$ esetén kapott eredményeket, a (3.2.1) összefüggés alapján felírható, hogy

$$
\begin{aligned}
& 4 \cdot S_{3}=(n+1) n^{3}+\left(\begin{array}{l}
3 \\
2
\end{array}\right) \cdot S_{2}-\left(\begin{array}{l}
3 \\
3
\end{array}\right) \cdot S_{1}=(n+1) n^{3}+3 \cdot \frac{n(n+1)(2 n+1)}{6}-\frac{n(n+1)}{2}= \\
& =\frac{n(n+1)}{2} \cdot\left(2 n^{2}+2 n+1-1\right)=\frac{n(n+1)}{2} \cdot\left(2 n^{2}+2 n\right)=n(n+1) n(n+1),
\end{aligned}
$$

ahonnan $S_{3}=\frac{n^{2}(n+1)^{2}}{4}$.

Tehát:

$$
S_{3}=1^{3}+2^{3}+3^{3}+\ldots+n^{3}=\frac{n^{2}(n+1)^{2}}{4}
$$

Ha $p=4$, akkor felhasználva az $S_{1}, S_{2}$ és $S_{3}$ eredményeit, a (3.2.1) összefüggés felhasználásával

$$
\begin{aligned}
& 5 \cdot S_{4}=(n+1) n^{4}+\left(\begin{array}{l}
4 \\
2
\end{array}\right) \cdot S_{3}-\left(\begin{array}{l}
4 \\
3
\end{array}\right) \cdot S_{2}+\left(\begin{array}{l}
4 \\
4
\end{array}\right) \cdot S_{1}= \\
& =(n+1) n^{4}+6 \cdot \frac{n^{2}(n+1)^{2}}{4}-4 \cdot \frac{n(n+1)(2 n+1)}{6}+\frac{n(n+1)}{2}= \\
& =\frac{n(n+1)}{6} \cdot\left[6 n^{3}+9 n(n+1)-4(2 n+1)+3\right]=\frac{n(n+1)}{6} \cdot\left(6 n^{3}+9 n^{2}+n-1\right)= \\
& =\frac{n(n+1)}{6} \cdot(2 n+1)\left(3 n^{2}+3 n-1\right) \\
& \text { ahonnan } S_{4}=\frac{n(n+1)(2 n+1)\left(3 n^{2}+3 n-1\right)}{30} .
\end{aligned}
$$


Tehát:

$$
S_{4}=1^{4}+2^{4}+3^{4}+\ldots+n^{4}=\frac{n(n+1)(2 n+1)\left(3 n^{2}+3 n-1\right)}{30} .
$$

Ha $p=5$, akkor az $S_{4}$-re kapott eredményt is felhasználva, a (3.2.1) összefüggés alapján

$$
\begin{aligned}
& 6 \cdot S_{5}=(n+1) n^{5}+\left(\begin{array}{l}
5 \\
2
\end{array}\right) \cdot S_{4}-\left(\begin{array}{l}
5 \\
3
\end{array}\right) \cdot S_{3}+\left(\begin{array}{l}
5 \\
4
\end{array}\right) \cdot S_{2}-\left(\begin{array}{l}
5 \\
5
\end{array}\right) \cdot S_{1}= \\
& =(n+1) n^{5}+10 \cdot \frac{n(n+1)(2 n+1)\left(3 n^{2}+3 n-1\right)}{30}-10 \cdot \frac{n^{2}(n+1)^{2}}{4}+5 \cdot \frac{n(n+1)(2 n+1)}{6}-\frac{n(n+1)}{2}= \\
& =\frac{n(n+1)}{6} \cdot\left[6 n^{4}+2(2 n+1)\left(3 n^{2}+3 n-1\right)-15 n(n+1)+5(2 n+1)-3\right]= \\
& =\frac{n(n+1)}{6} \cdot\left(6 n^{4}+12 n^{3}+3 n^{2}-3 n\right)=\frac{n^{2}(n+1)}{2} \cdot\left(2 n^{3}+4 n^{2}+n-1\right)= \\
& =\frac{n^{2}(n+1)}{2} \cdot(n+1)\left(2 n^{2}+2 n-1\right) \\
& \text { ahonnan } S_{5}=\frac{n^{2}(n+1)^{2}\left(2 n^{2}+2 n-1\right)}{12}
\end{aligned}
$$

Tehát:

$$
S_{5}=1^{5}+2^{5}+3^{5}+\ldots+n^{5}=\frac{n^{2}(n+1)^{2}\left(2 n^{2}+2 n-1\right)}{12} .
$$

Láthatóan ez a módszer is szépen előállítja a 3.1.2. fejezetben már levezetett képleteket, és használata szerencsére nem igényel „túl mély” kombinatorikai tudást. Épp ezért a módszer akár egyfajta „kitekintésként” alkalmazható a középiskolai oktatásban is, persze a tudásszint függvényében.

\section{Megjegyzés}

Ha a (3.2.1) összefüggést átírjuk a

$$
(p+1) \cdot S_{p}=2 \cdot S_{1} \cdot n^{p-1}+\left(\begin{array}{l}
p \\
2
\end{array}\right) \cdot S_{p-1}-\left(\begin{array}{l}
p \\
3
\end{array}\right) \cdot S_{p-2}+\ldots+(-1)^{p} \cdot\left(\begin{array}{l}
p \\
p
\end{array}\right) \cdot S_{1}
$$

alakra és rendre behelyettesítjük a $p$ megfelelö értékeit, $S_{p}$-t felírhatjuk csak az $n$ és az $S_{1}$ segítségével, s ezáltal lényegesen egyszerübbé válik az $S_{1} \mid S_{p}$ oszthatóságra vonatkozó bizonyítás is.

Így például:

$$
\begin{array}{ll}
S_{2}=\frac{2 n+1}{3} \cdot S_{1} ; & S_{3}=\frac{n(n+1)}{2} \cdot S_{1} ; \\
S_{4}=\frac{(2 n+1)\left(3 n^{2}+3 n-1\right)}{15} \cdot S_{1} ; & S_{5}=\frac{n(n+1)\left(2 n^{2}+2 n-1\right)}{6} \cdot S_{1} ;
\end{array}
$$


Az itt bemutatott összefüggések segítségével sorra megadható az $S_{p}$, csupán az $S_{1}$ és $S_{2}$ függvényében, minden $p \geq 3$ természetes szám esetén. Ezt szemlélteti az alábbi néhány felírás:

$$
S_{3}=S_{1}^{2} ; \quad S_{4}=\frac{6 \cdot S_{1}-1}{5} \cdot S_{2} ; \quad S_{5}=\frac{4 \cdot S_{1}-1}{3} \cdot S_{1}^{2} .
$$

Megemlítjük, hogy e tekintetben további eredmények találhatóak a [44]-ben.

\section{$\underline{\text { 8. Megjegyzés }}$}

Szemléletes bizonyítás az $S_{3}$ kiszámítására (3.2.1. ábra):

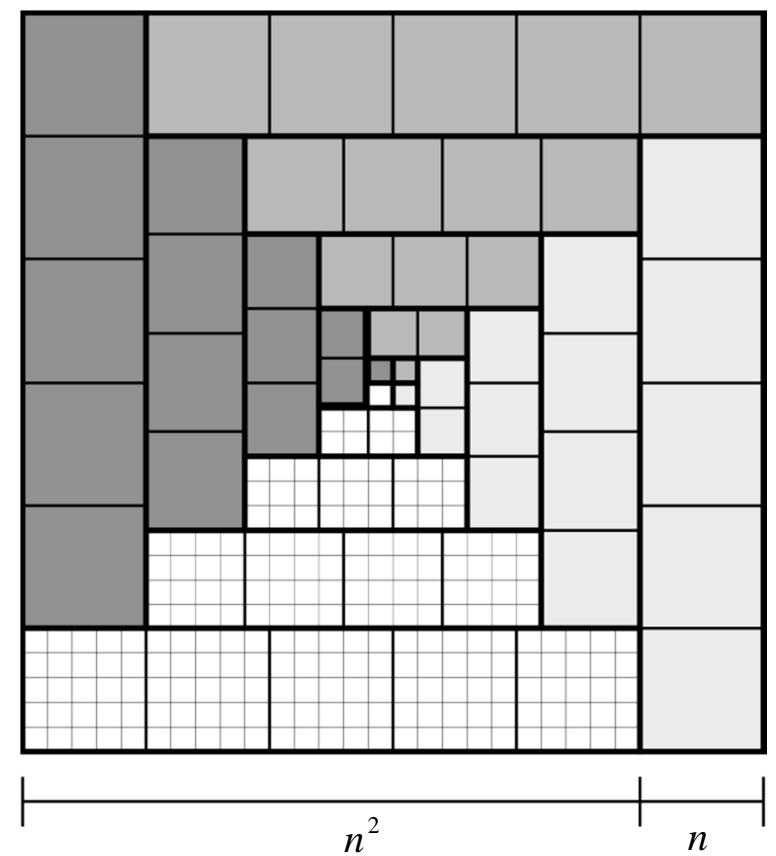

$$
1^{3}+2^{3}+3^{3}+\ldots+n^{3}=\frac{1}{4} \cdot\left(n^{2}+n\right)^{2}=\frac{n^{2}(n+1)^{2}}{4}
$$

\subsection{1. ábra}

Szemléletes bizonyítás az $S_{3}=S_{1}^{2}$ igazolására (3.2.2. ábra):
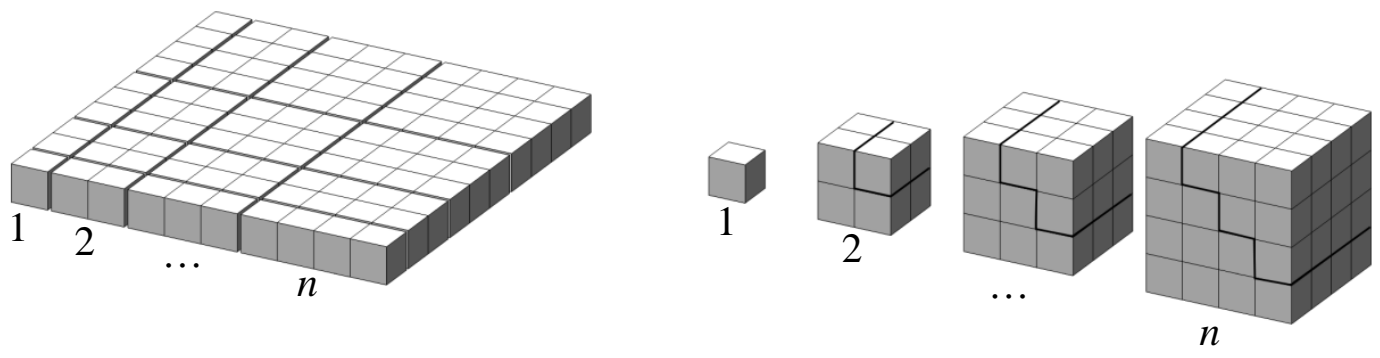

$$
(1+2+\ldots+n)^{2}=1^{3}+2^{3}+\ldots+n^{3}
$$

\subsection{2. ábra}




\subsubsection{Rekurziós összefüggések előállítása a második módszer segítségével}

Felvetődik a kérdés: nem tudnánk-e a módszer segítségével mi is újabb összefüggéseket készíteni vagy a már meglevőket bizonyítani? Az alábbiakban látni fogjuk, hogy ez lehetséges. Erre vonatkozóan a továbbiakban két eljárást mutatunk be, az egyiket a páratlan indexű, míg a másikat a páros indexü $S_{p}$-k esetére (lásd [7] 93-94. o.).

\section{$\underline{\text { Rekurzió páratlan index esetére: }}$}

Itt a gondolatmenet abban áll, hogy az adott eljárással összefüggéseket állapítunk meg a páratlan indexü $S_{i}$ hatványösszegek között, illetve kifejezzük ezeket csak az $S_{1}$ segítségével.

Induljunk ki a következő összefüggésből ( $\left.p \in Z^{+}, a \in R\right)$ :

$$
\begin{aligned}
& {[a \cdot(a+1)]^{p}-[(a-1) \cdot a]^{p}=a^{p} \cdot(a+1)^{p}-a^{p} \cdot(a-1)^{p}=a^{p} \cdot\left[(a+1)^{p}-(a-1)^{p}\right]=} \\
& =a^{p} \cdot\left[a^{p}+\left(\begin{array}{l}
p \\
1
\end{array}\right) \cdot a^{p-1}+\left(\begin{array}{l}
p \\
2
\end{array}\right) \cdot a^{p-2}+\ldots+\left(\begin{array}{l}
p \\
p
\end{array}\right)-a^{p}+\left(\begin{array}{l}
p \\
1
\end{array}\right) \cdot a^{p-1}-\left(\begin{array}{l}
p \\
2
\end{array}\right) \cdot a^{p-2}+\ldots+(-1)^{p+1} \cdot\left(\begin{array}{l}
p \\
p
\end{array}\right)\right]= \\
& =a^{p} \cdot\left[2 \cdot\left(\begin{array}{l}
p \\
1
\end{array}\right) \cdot a^{p-1}+2 \cdot\left(\begin{array}{l}
p \\
3
\end{array}\right) \cdot a^{p-3}+2 \cdot\left(\begin{array}{l}
p \\
5
\end{array}\right) \cdot a^{p-5}+\ldots\right]= \\
& =2 \cdot\left(\begin{array}{l}
p \\
1
\end{array}\right) \cdot a^{2 p-1}+2 \cdot\left(\begin{array}{l}
p \\
3
\end{array}\right) \cdot a^{2 p-3}+2 \cdot\left(\begin{array}{l}
p \\
5
\end{array}\right) \cdot a^{2 p-5}+\ldots,
\end{aligned}
$$

azaz

$$
[a \cdot(a+1)]^{p}-[(a-1) \cdot a]^{p}=2 \cdot\left(\begin{array}{l}
p \\
1
\end{array}\right) \cdot a^{2 p-1}+2 \cdot\left(\begin{array}{l}
p \\
3
\end{array}\right) \cdot a^{2 p-3}+2 \cdot\left(\begin{array}{l}
p \\
5
\end{array}\right) \cdot a^{2 p-5}+\ldots,
$$

ahol a jobb oldali utolsó tag $2 a^{p}$ vagy $2 \cdot\left(\begin{array}{c}p \\ p-1\end{array}\right) \cdot a^{p+1}$ attól függően, hogy $p$ páratlan vagy páros szám.

Ekkor a (3.2.4) egyenlőség alapján

$$
\begin{aligned}
& \sum_{i=1}^{n}\left\{[i \cdot(i+1)]^{p}-[(i-1) \cdot i]^{p}\right\}=\sum_{i=1}^{n}\left[2 \cdot\left(\begin{array}{l}
p \\
1
\end{array}\right) \cdot i^{2 p-1}+2 \cdot\left(\begin{array}{l}
p \\
3
\end{array}\right) \cdot i^{2 p-3}+2 \cdot\left(\begin{array}{l}
p \\
5
\end{array}\right) \cdot i^{2 p-5}+\ldots\right]= \\
& =2 \cdot\left(\begin{array}{l}
p \\
1
\end{array}\right) \cdot \sum_{i=1}^{n} i^{2 p-1}+2 \cdot\left(\begin{array}{l}
p \\
3
\end{array}\right) \cdot \sum_{i=1}^{n} i^{2 p-3}+2 \cdot\left(\begin{array}{l}
p \\
5
\end{array}\right) \cdot \sum_{i=1}^{n} i^{2 p-5}+\ldots
\end{aligned}
$$

A bal oldalon egy teleszkópikus összeg található, amely az összevonások után nem más, mint $[n(n+1)]^{p}-0$, vagyis

$$
[n(n+1)]^{p}=2 \cdot\left(\begin{array}{l}
p \\
1
\end{array}\right) \cdot S_{2 p-1}+2 \cdot\left(\begin{array}{l}
p \\
3
\end{array}\right) \cdot S_{2 p-3}+2 \cdot\left(\begin{array}{l}
p \\
5
\end{array}\right) \cdot S_{2 p-5}+\ldots .
$$

Figyelembe véve, hogy $n(n+1)=2 \cdot S_{1}$, így a (3.2.5) összefüggés a következőre módosul:

$$
2^{p} \cdot S_{1}^{p}=2 \cdot\left(\begin{array}{l}
p \\
1
\end{array}\right) \cdot S_{2 p-1}+2 \cdot\left(\begin{array}{l}
p \\
3
\end{array}\right) \cdot S_{2 p-3}+2 \cdot\left(\begin{array}{l}
p \\
5
\end{array}\right) \cdot S_{2 p-5}+\ldots .
$$


Innen 2-vel történő osztással kapjuk, hogy

$$
2^{p-1} \cdot S_{1}^{p}=\left(\begin{array}{c}
p \\
1
\end{array}\right) \cdot S_{2 p-1}+\left(\begin{array}{c}
p \\
3
\end{array}\right) \cdot S_{2 p-3}+\left(\begin{array}{c}
p \\
5
\end{array}\right) \cdot S_{2 p-5}+\ldots
$$

ahol a jobb oldalon az utolsó tag $S_{p}$ vagy $\left(\begin{array}{c}p \\ p-1\end{array}\right) \cdot S_{p+1}=p \cdot S_{p+1}$ attól függően, hogy $p$ páratlan vagy páros szám.

A kapott (3.2.6) formula segítségével újabb összefüggések írhatók fel az $S_{i}$ hatványösszegek között, illetve kifejezhetjük a páratlan indexű $S_{i}$-ket az $S_{1}$ segítségével. Ennek szemléltetéseként lássuk az alábbi példákat!

$\mathrm{Ha}$

$$
\begin{aligned}
& p=1 \quad S_{1}=S_{1} \\
& p=2 \quad 2 \cdot S_{1}^{2}=\left(\begin{array}{l}
2 \\
1
\end{array}\right) \cdot S_{3} \\
& S_{1}^{2}=S_{3}, \quad \text { illetve } S_{3}=S_{1}^{2} \text {. } \\
& p=3 \quad 2^{2} \cdot S_{1}^{3}=\left(\begin{array}{l}
3 \\
1
\end{array}\right) \cdot S_{5}+\left(\begin{array}{l}
3 \\
3
\end{array}\right) \cdot S_{3} \\
& 4 \cdot S_{1}^{3}=3 \cdot S_{5}+S_{3}, \quad \quad \text { illetve } \quad S_{5}=\frac{S_{1}^{2}}{3} \cdot\left(4 \cdot S_{1}-1\right) . \\
& p=4 \quad 2^{3} \cdot S_{1}^{4}=\left(\begin{array}{l}
4 \\
1
\end{array}\right) \cdot S_{7}+\left(\begin{array}{l}
4 \\
3
\end{array}\right) \cdot S_{5} \\
& 2 \cdot S_{1}^{4}=S_{7}+S_{5}, \quad \quad \text { illetve } \quad S_{7}=\frac{S_{1}^{2}}{3} \cdot\left(6 \cdot S_{1}^{2}-4 \cdot S_{1}+1\right) . \\
& p=5 \quad 2^{4} \cdot S_{1}^{5}=\left(\begin{array}{l}
5 \\
1
\end{array}\right) \cdot S_{9}+\left(\begin{array}{l}
5 \\
3
\end{array}\right) \cdot S_{7}+\left(\begin{array}{l}
5 \\
5
\end{array}\right) \cdot S_{5} \\
& 16 \cdot S_{1}^{5}=5 \cdot S_{9}+10 \cdot S_{7}+S_{5}, \quad \text { illetve } \\
& S_{9}=\frac{S_{1}^{2}}{5} \cdot\left(16 \cdot S_{1}^{3}-20 \cdot S_{1}^{2}+12 \cdot S_{1}-3\right) \text {. }
\end{aligned}
$$

\section{Megjegyzés}

A $p=4$ esetre kapott eredmény azért is érdekes, mert valamiféle "hasonlóságot” mutat a $p=2$ esettel. Míg ez utóbbi szerint a pozitív egész számok köbeinek összege mindig egy teljes négyzet lesz, addig az előbbi alapján a pozitív egész számok ötödik és hetedik hatványai összegének a fele (azaz $S_{5}$ és $S_{7}$ számtani közepe) egy egész szám negyedik hatványa lesz minden esetben, vagyis

$$
(1+2+3+\ldots+n)^{4}=\frac{\left(1^{5}+2^{5}+3^{5}+\ldots+n^{5}\right)+\left(1^{7}+2^{7}+3^{7}+\ldots+n^{7}\right)}{2}=\left(1^{3}+2^{3}+3^{3}+\ldots+n^{3}\right)^{2} \text {. }
$$


$\underline{\text { Rekurzió páros index esetére: }}$

Ahogy az a páratlan index esetében történt, az alább levezetésre kerülő eljárással összefüggéseket állítunk fel ezúttal a páros indexü $S_{i}$ hatványösszegek között, illetve kifejezzük ezeket az $S_{1}$ és $S_{2}$ segítségével.

Ezúttal induljunk ki a következő összefüggésből $\left(p \in Z^{+}, a \in R\right)$ :

$$
\begin{aligned}
& (2 a+1) \cdot[a \cdot(a+1)]^{p}-(2 a-1) \cdot[(a-1) \cdot a]^{p}= \\
& =2 a \cdot\left\{[a \cdot(a+1)]^{p}-[(a-1) \cdot a]^{p}\right\}+\left\{[a \cdot(a+1)]^{p}+[(a-1) \cdot a]^{p}\right\}= \\
& =2 \cdot a^{p+1} \cdot\left[(a+1)^{p}-(a-1)^{p}\right]+a^{p} \cdot\left[(a+1)^{p}+(a-1)^{p}\right] .
\end{aligned}
$$

Felhasználva a páratlan indexre vonatkozó eljárás során kapott részeredményeket:

$$
\begin{aligned}
& 2 \cdot a^{p+1} \cdot\left[(a+1)^{p}-(a-1)^{p}\right]=2 \cdot a^{p+1} \cdot\left[2 \cdot\left(\begin{array}{l}
p \\
1
\end{array}\right) \cdot a^{p-1}+2 \cdot\left(\begin{array}{l}
p \\
3
\end{array}\right) \cdot a^{p-3}+2 \cdot\left(\begin{array}{l}
p \\
5
\end{array}\right) \cdot a^{p-5}+\ldots\right]= \\
& =4 \cdot\left(\begin{array}{l}
p \\
1
\end{array}\right) \cdot a^{2 p}+4 \cdot\left(\begin{array}{l}
p \\
3
\end{array}\right) \cdot a^{2 p-2}+4 \cdot\left(\begin{array}{l}
p \\
5
\end{array}\right) \cdot a^{2 p-4}+\ldots,
\end{aligned}
$$

illetve

$$
\begin{aligned}
& a^{p} \cdot\left[(a+1)^{p}+(a-1)^{p}\right]=a^{p} \cdot\left[2 \cdot\left(\begin{array}{l}
p \\
0
\end{array}\right) \cdot a^{p}+2 \cdot\left(\begin{array}{l}
p \\
2
\end{array}\right) \cdot a^{p-2}+2 \cdot\left(\begin{array}{l}
p \\
4
\end{array}\right) \cdot a^{p-4}+\ldots\right]= \\
& =2 \cdot\left(\begin{array}{l}
p \\
0
\end{array}\right) \cdot a^{2 p}+2 \cdot\left(\begin{array}{l}
p \\
2
\end{array}\right) \cdot a^{2 p-2}+2 \cdot\left(\begin{array}{l}
p \\
4
\end{array}\right) \cdot a^{2 p-4}+\ldots .
\end{aligned}
$$

Mindezek alapján kapjuk:

$$
\begin{aligned}
& (2 a+1) \cdot[a \cdot(a+1)]^{p}-(2 a-1) \cdot[(a-1) \cdot a]^{p}=2 \cdot a^{2 p} \cdot\left[\left(\begin{array}{l}
p \\
0
\end{array}\right)+2 \cdot\left(\begin{array}{l}
p \\
1
\end{array}\right)\right]+ \\
& +2 \cdot a^{2 p-2} \cdot\left[\left(\begin{array}{l}
p \\
2
\end{array}\right)+2 \cdot\left(\begin{array}{l}
p \\
3
\end{array}\right)\right]+2 \cdot a^{2 p-4} \cdot\left[\left(\begin{array}{l}
p \\
4
\end{array}\right)+2 \cdot\left(\begin{array}{l}
p \\
5
\end{array}\right)\right]+\ldots,
\end{aligned}
$$

ahol a jobb oldali utolsó tag $2 \cdot a^{p}$ vagy $2 \cdot\left[\left(\begin{array}{c}p \\ p-1\end{array}\right)+2\right] \cdot a^{p+1}$ attól függően, hogy $p$ páros vagy páratlan szám.

Ekkor a (3.2.7) összefüggés alapján

$$
\begin{aligned}
& \sum_{i=1}^{n}\left\{(2 i+1) \cdot[i \cdot(i+1)]^{p}-(2 i-1) \cdot[(i-1) \cdot i]^{p}\right\}= \\
& =\sum_{i=1}^{n}\left\{2 \cdot i^{2 p} \cdot\left[\left(\begin{array}{l}
p \\
0
\end{array}\right)+2 \cdot\left(\begin{array}{l}
p \\
1
\end{array}\right)\right]+2 \cdot i^{2 p-2} \cdot\left[\left(\begin{array}{l}
p \\
2
\end{array}\right)+2 \cdot\left(\begin{array}{l}
p \\
3
\end{array}\right)\right]+2 \cdot i^{2 p-4} \cdot\left[\left(\begin{array}{l}
p \\
4
\end{array}\right)+2 \cdot\left(\begin{array}{l}
p \\
5
\end{array}\right)\right]+\ldots\right\}= \\
& =2 \cdot\left[\left(\begin{array}{l}
p \\
0
\end{array}\right)+2 \cdot\left(\begin{array}{l}
p \\
1
\end{array}\right)\right] \cdot \sum_{i=1}^{n} i^{2 p}+2 \cdot\left[\left(\begin{array}{l}
p \\
2
\end{array}\right)+2 \cdot\left(\begin{array}{l}
p \\
3
\end{array}\right)\right] \cdot \sum_{i=1}^{n} i^{2 p-2}+2 \cdot\left[\left(\begin{array}{l}
p \\
4
\end{array}\right)+2 \cdot\left(\begin{array}{l}
p \\
5
\end{array}\right)\right] \cdot \sum_{i=1}^{n} i^{2 p-4}+\ldots .
\end{aligned}
$$


A bal oldalon egy teleszkópikus összeg található, melynek eredménye az összevonások után $(2 n+1)[n(n+1)]^{p}-0$, vagyis

$$
\begin{aligned}
& (2 n+1)[n(n+1)]^{p}-0=2 \cdot\left[\left(\begin{array}{l}
p \\
0
\end{array}\right)+2 \cdot\left(\begin{array}{l}
p \\
1
\end{array}\right)\right] \cdot S_{2 p}+ \\
& +2 \cdot\left[\left(\begin{array}{l}
p \\
2
\end{array}\right)+2 \cdot\left(\begin{array}{l}
p \\
3
\end{array}\right)\right] \cdot S_{2 p-2}+2 \cdot\left[\left(\begin{array}{l}
p \\
4
\end{array}\right)+2 \cdot\left(\begin{array}{l}
p \\
5
\end{array}\right)\right] \cdot S_{2 p-4}+\ldots .
\end{aligned}
$$

Figyelembe véve, hogy $n(n+1)(2 n+1)=6 \cdot S_{2}$, illetve $n(n+1)=2 \cdot S_{1}$, a (3.2.8) összefüggés átalakul:

$$
\begin{aligned}
& 6 \cdot S_{2} \cdot 2^{p-1} \cdot S_{1}^{p-1}= \\
& =2 \cdot\left[\left(\begin{array}{l}
p \\
0
\end{array}\right)+2 \cdot\left(\begin{array}{l}
p \\
1
\end{array}\right)\right] \cdot S_{2 p}+2 \cdot\left[\left(\begin{array}{l}
p \\
2
\end{array}\right)+2 \cdot\left(\begin{array}{l}
p \\
3
\end{array}\right)\right] \cdot S_{2 p-2}+2 \cdot\left[\left(\begin{array}{l}
p \\
4
\end{array}\right)+2 \cdot\left(\begin{array}{l}
p \\
5
\end{array}\right)\right] \cdot S_{2 p-4}+\ldots,
\end{aligned}
$$

amelyből 2-vel történő osztás után kapjuk, hogy

$$
\begin{aligned}
& 3 \cdot 2^{p-1} \cdot S_{2} \cdot S_{1}^{p-1}= \\
& =\left[\left(\begin{array}{l}
p \\
0
\end{array}\right)+2 \cdot\left(\begin{array}{l}
p \\
1
\end{array}\right)\right] \cdot S_{2 p}+\left[\left(\begin{array}{l}
p \\
2
\end{array}\right)+2 \cdot\left(\begin{array}{l}
p \\
3
\end{array}\right)\right] \cdot S_{2 p-2}+\left[\left(\begin{array}{l}
p \\
4
\end{array}\right)+2 \cdot\left(\begin{array}{l}
p \\
5
\end{array}\right)\right] \cdot S_{2 p-4}+\ldots,
\end{aligned}
$$

ahol a jobb oldali utolsó tag $S_{p}$ vagy $\left[\left(\begin{array}{c}p \\ p-1\end{array}\right)+2\right] \cdot S_{p+1}=(p+2) \cdot S_{p+1}$ attól függően, hogy $p$ páros vagy páratlan szám.

A kapott (3.2.9) egyenlőség segítségével újabb összefüggések írhatók fel az $S_{i}$ hatványösszegek között, illetve kifejezhetőek a páros indexü $S_{i}$ hatványösszegek az $S_{1}$-gyel és $S_{2}$-vel. Lássunk erre néhány példát!

$\mathrm{Ha}$

$$
\begin{aligned}
& p=1 \quad 3 \cdot S_{2}=\left[\left(\begin{array}{l}
1 \\
0
\end{array}\right)+2 \cdot\left(\begin{array}{l}
1 \\
1
\end{array}\right)\right] \cdot S_{2} \\
& S_{2}=S_{2} \text {. } \\
& p=2 \quad 6 \cdot S_{2} \cdot S_{1}=\left[\left(\begin{array}{l}
2 \\
0
\end{array}\right)+2 \cdot\left(\begin{array}{l}
2 \\
1
\end{array}\right)\right] \cdot S_{4}+\left(\begin{array}{l}
2 \\
2
\end{array}\right) \cdot S_{2} \\
& 6 \cdot S_{2} \cdot S_{1}=5 \cdot S_{4}+S_{2}, \quad \text { illetve } \quad S_{4}=\frac{S_{2}}{5} \cdot\left(6 \cdot S_{1}-1\right) \\
& p=3 \quad 12 \cdot S_{2} \cdot S_{1}^{2}=\left[\left(\begin{array}{l}
3 \\
0
\end{array}\right)+2 \cdot\left(\begin{array}{l}
3 \\
1
\end{array}\right)\right] \cdot S_{6}+\left[\left(\begin{array}{l}
3 \\
2
\end{array}\right)+2 \cdot\left(\begin{array}{l}
3 \\
3
\end{array}\right)\right] \cdot S_{4} \\
& 12 \cdot S_{2} \cdot S_{1}^{2}=7 \cdot S_{6}+5 \cdot S_{4}, \quad \text { illetve } \quad S_{6}=\frac{S_{2}}{7} \cdot\left(12 \cdot S_{1}^{2}-6 \cdot S_{1}+1\right) \text {. }
\end{aligned}
$$




$$
\begin{aligned}
& p=4 \quad 24 \cdot S_{2} \cdot S_{1}^{3}=\left[\left(\begin{array}{l}
4 \\
0
\end{array}\right)+2 \cdot\left(\begin{array}{l}
4 \\
1
\end{array}\right)\right] \cdot S_{8}+\left[\left(\begin{array}{l}
4 \\
2
\end{array}\right)+2 \cdot\left(\begin{array}{l}
4 \\
3
\end{array}\right)\right] \cdot S_{6}+\left(\begin{array}{l}
4 \\
4
\end{array}\right) \cdot S_{4} \\
& 24 \cdot S_{2} \cdot S_{1}^{3}=9 \cdot S_{8}+14 \cdot S_{6}+S_{4}, \quad \text { illetve } \\
& S_{8}=\frac{S_{2}}{15} \cdot\left(40 \cdot S_{1}^{3}-40 \cdot S_{1}^{2}+18 \cdot S_{1}-3\right) . \\
& p=5 \quad 48 \cdot S_{2} \cdot S_{1}^{4}=\left[\left(\begin{array}{l}
5 \\
0
\end{array}\right)+2 \cdot\left(\begin{array}{l}
5 \\
1
\end{array}\right)\right] \cdot S_{10}+\left[\left(\begin{array}{l}
5 \\
2
\end{array}\right)+2 \cdot\left(\begin{array}{l}
5 \\
3
\end{array}\right)\right] \cdot S_{8}+\left[\left(\begin{array}{l}
5 \\
4
\end{array}\right)+2 \cdot\left(\begin{array}{l}
5 \\
5
\end{array}\right)\right] \cdot S_{6} \\
& 48 \cdot S_{2} \cdot S_{1}^{4}=11 \cdot S_{10}+30 \cdot S_{8}+7 \cdot S_{6}, \quad \text { illetve } \\
& S_{10}=\frac{S_{2}}{11} \cdot\left(48 \cdot S_{1}^{4}-80 \cdot S_{1}^{3}+68 \cdot S_{1}^{2}-30 \cdot S_{1}+5\right) .
\end{aligned}
$$

\section{Megjegyzés}

Figyelembe véve, hogy $\left(\begin{array}{c}p \\ 2 k\end{array}\right)+\left(\begin{array}{c}p \\ 2 k+1\end{array}\right)=\left(\begin{array}{c}p+1 \\ 2 k+1\end{array}\right)$, ahol $0 \leq k \leq \frac{p-1}{2}$ és $k \in N$, a (3.2.9) összefüggés átírható

$3 \cdot 2^{p-1} \cdot S_{2} \cdot S_{1}^{p-1}=\left[\left(\begin{array}{c}p \\ 1\end{array}\right)+\left(\begin{array}{c}p+1 \\ 1\end{array}\right)\right] \cdot S_{2 p}+\left[\left(\begin{array}{c}p \\ 3\end{array}\right)+\left(\begin{array}{c}p+1 \\ 3\end{array}\right)\right] \cdot S_{2 p-2}+\left[\left(\begin{array}{c}p \\ 5\end{array}\right)+\left(\begin{array}{c}p+1 \\ 5\end{array}\right)\right] \cdot S_{2 p-4}+\ldots$,

alakra is, ahol a jobb oldali utolsó tag $S_{p}$ vagy $(p+2) \cdot S_{p+1}$ attól függően, hogy $p$ páros vagy páratlan szám.

Végeredményként a fenti módszerről elmondható, hogy a rekurziós összefüggés általános alakja egy - viszonylag ritkán alkalmazott - különbség kombinatorikus kifejtéséből adódik. A $p=3 ; 4 ; 5$ pozitív egészekre felírt konkrét esetek pedig megadják az első módszer segítségével már megismert képleteket. Emellett több konkrét összeg között is megmutattunk szép összefüggéseket. Ezek közül is kiemelhető az, hogy az első $n$ pozitív természetes szám összegének 4. hatványa előáll e számok 5. hatványai és 7. hatványai összegének számtani közepeként.

\subsection{A binomiális tételen alapuló módszer}

A binomiális tétel segítségével történő rekurzió előállítás a legismertebb metodika. A legtöbb könyv, tanulmány ezzel a módszerrel számol (lásd [7] 79-80. o. vagy [17]). Értelemszerüen ennek alkalmazásához is szükségeltetnek kombinatorikai eszközök (kombinációk kiszámításának módja, Newton binomiális tétele).

A számítás gondolatmenete a következő: Newton binomiális tétele alapján kifejtjük az $(a+1)$ kifejezés $(p+1)$-edik hatványát. Az eredményt átrendezve egy olyan azonossághoz jutunk, amelybe rendre behelyettesítjük az $1,2, \ldots, n$ természetes számokat. Az így kapott összefüggéseket tagonként összeadva és az egynemü tagokat összevonva, egy rekurziós 
összefüggést kapunk. Ez a rekurziós képlet adja meg az $S_{p}$ hatványösszeget az előző összegek (vagyis $S_{1}, S_{2}, \ldots, S_{p-1}$ ) függvényében.

\subsubsection{Rekurziós összefüggés a binomiális tétel segítségével}

Induljunk ki tehát az

$$
(a+1)^{p+1}=a^{p+1}+\left(\begin{array}{c}
p+1 \\
1
\end{array}\right) \cdot a^{p}+\left(\begin{array}{c}
p+1 \\
2
\end{array}\right) \cdot a^{p-1}+\left(\begin{array}{c}
p+1 \\
3
\end{array}\right) \cdot a^{p-2}+\ldots+\left(\begin{array}{c}
p+1 \\
p
\end{array}\right) \cdot a+\left(\begin{array}{c}
p+1 \\
p+1
\end{array}\right)
$$

azonosságból, ahol $p \in N$ és $a \in R$, melyet átrendezve kapjuk, hogy

$$
(a+1)^{p+1}-a^{p+1}=\left(\begin{array}{c}
p+1 \\
1
\end{array}\right) \cdot a^{p}+\left(\begin{array}{c}
p+1 \\
2
\end{array}\right) \cdot a^{p-1}+\left(\begin{array}{c}
p+1 \\
3
\end{array}\right) \cdot a^{p-2}+\ldots+\left(\begin{array}{c}
p+1 \\
p
\end{array}\right) \cdot a+\left(\begin{array}{c}
p+1 \\
p+1
\end{array}\right) .
$$

Ekkor

$$
\begin{aligned}
& \sum_{i=1}^{n}\left[(i+1)^{p+1}-i^{p+1}\right]=\sum_{i=1}^{n}\left[\left(\begin{array}{c}
p+1 \\
1
\end{array}\right) \cdot i^{p}+\left(\begin{array}{c}
p+1 \\
2
\end{array}\right) \cdot i^{p-1}+\left(\begin{array}{c}
p+1 \\
3
\end{array}\right) \cdot i^{p-2}+\ldots+\left(\begin{array}{c}
p+1 \\
p
\end{array}\right) \cdot i+\left(\begin{array}{c}
p+1 \\
p+1
\end{array}\right)\right]= \\
& =\left(\begin{array}{c}
p+1 \\
1
\end{array}\right) \cdot \sum_{i=1}^{n} i^{p}+\left(\begin{array}{c}
p+1 \\
2
\end{array}\right) \cdot \sum_{i=1}^{n} i^{p-1}+\left(\begin{array}{c}
p+1 \\
3
\end{array}\right) \cdot \sum_{i=1}^{n} i^{p-2}+\ldots+\left(\begin{array}{c}
p+1 \\
p
\end{array}\right) \cdot \sum_{i=1}^{n} i+\left(\begin{array}{c}
p+1 \\
p+1
\end{array}\right) \cdot \sum_{i=1}^{n} 1 .
\end{aligned}
$$

A baloldalon egy teleszkópikus összeg található, amely az összevonások után $(n+1)^{p+1}-1^{p+1}$ alakra módosul, vagyis

$$
(n+1)^{p+1}-1=\left(\begin{array}{c}
p+1 \\
1
\end{array}\right) \cdot S_{p}+\left(\begin{array}{c}
p+1 \\
2
\end{array}\right) \cdot S_{p-1}+\left(\begin{array}{c}
p+1 \\
3
\end{array}\right) \cdot S_{p-2}+\ldots+\left(\begin{array}{c}
p+1 \\
p
\end{array}\right) \cdot S_{1}+\left(\begin{array}{c}
p+1 \\
p+1
\end{array}\right) \cdot n .
$$

Átrendezés után adódik, hogy

$$
\left(\begin{array}{c}
p+1 \\
1
\end{array}\right) \cdot S_{p}=(n+1)^{p+1}-\left(\begin{array}{c}
p+1 \\
2
\end{array}\right) \cdot S_{p-1}-\left(\begin{array}{c}
p+1 \\
3
\end{array}\right) \cdot S_{p-2}-\ldots-\left(\begin{array}{c}
p+1 \\
p
\end{array}\right) \cdot S_{1}-(n+1),
$$

ahonnan - felhasználva, hogy $\left(\begin{array}{c}p+1 \\ 1\end{array}\right)=p+1$ és $\left(\begin{array}{c}p+1 \\ p+1\end{array}\right)=1-$ kapjuk, hogy

$$
(p+1) \cdot S_{p}=(n+1)^{p+1}-\left(\begin{array}{c}
p+1 \\
2
\end{array}\right) \cdot S_{p-1}-\left(\begin{array}{c}
p+1 \\
3
\end{array}\right) \cdot S_{p-2}-\ldots-\left(\begin{array}{c}
p+1 \\
p
\end{array}\right) \cdot S_{1}-\left(\begin{array}{c}
p+1 \\
p+1
\end{array}\right) \cdot(n+1) \text {. }
$$

Innen

$$
S_{p}=\frac{1}{p+1} \cdot\left[(n+1)^{p+1}-\left(\begin{array}{c}
p+1 \\
2
\end{array}\right) \cdot S_{p-1}-\left(\begin{array}{c}
p+1 \\
3
\end{array}\right) \cdot S_{p-2}-\ldots-\left(\begin{array}{c}
p+1 \\
p
\end{array}\right) \cdot S_{1}-\left(\begin{array}{c}
p+1 \\
p+1
\end{array}\right) \cdot(n+1)\right] .
$$

vagy

$$
S_{p}=\frac{(n+1)^{p+1}-(n+1)-\sum_{k=2}^{p}\left(\begin{array}{c}
p+1 \\
k
\end{array}\right) \cdot S_{p+1-k}}{p+1} .
$$


Az $S_{p}$ kiszámítása láthatóan ez esetben is az $S_{1}, S_{2}, \ldots, S_{p-1}$ hatványösszegekre kapott eredmények felhasználásával történik.

\subsubsection{A kapott összefüggés néhány speciális esete}

A következőkben felhasználva az $S_{1}$ és $S_{2}$ összegekre esetén kapott eredményeket, megállapítjuk az $S_{3}, S_{4}$ és $S_{5}$ összegekre érvényes összefüggéseket.

Ha $p=3$, akkor az $S_{1}$ és $S_{2}$ eredményeit felhasználva a (3.3.1) összefüggés alapján

$$
\begin{aligned}
& 4 \cdot S_{3}=(n+1)^{4}-\left(\begin{array}{l}
4 \\
2
\end{array}\right) \cdot S_{2}-\left(\begin{array}{l}
4 \\
3
\end{array}\right) \cdot S_{1}-\left(\begin{array}{l}
4 \\
4
\end{array}\right) \cdot(n+1)= \\
& =(n+1)^{4}-6 \cdot \frac{n(n+1)(2 n+1)}{6}-4 \cdot \frac{n(n+1)}{2}-(n+1)= \\
& =(n+1) \cdot\left(n^{3}+3 n^{2}+3 n+1-2 n^{2}-n-2 n-1\right)=(n+1) \cdot\left(n^{3}+n^{2}\right)=n^{2}(n+1)^{2},
\end{aligned}
$$

ahonnan $S_{3}=\frac{n^{2}(n+1)^{2}}{4}$.

Tehát:

$$
S_{3}=1^{3}+2^{3}+3^{3}+\ldots+n^{3}=\frac{n^{2}(n+1)^{2}}{4} .
$$

Ha $p=4$, akkor az $S_{1}, S_{2}$ és $S_{3}$ eredményeit felhasználva, a (3.3.1) összefüggés szerint

$$
\begin{aligned}
& 5 \cdot S_{4}=(n+1)^{5}-\left(\begin{array}{l}
5 \\
2
\end{array}\right) \cdot S_{3}-\left(\begin{array}{l}
5 \\
3
\end{array}\right) \cdot S_{2}-\left(\begin{array}{l}
5 \\
4
\end{array}\right) \cdot S_{1}-\left(\begin{array}{l}
5 \\
5
\end{array}\right) \cdot(n+1)= \\
& =(n+1)^{5}-10 \cdot \frac{n^{2}(n+1)^{2}}{4}-10 \cdot \frac{n(n+1)(2 n+1)}{6}-5 \cdot \frac{n(n+1)}{2}-(n+1) .
\end{aligned}
$$

Kiemelve $\frac{n+1}{6}$-t, a müveletek elvégzése és az összevonások után kapjuk, hogy

$$
\begin{aligned}
& 5 \cdot S_{4}=\frac{n+1}{6} \cdot\left(6 n^{4}+9 n^{3}+n^{2}-n\right)=\frac{n(n+1)}{6} \cdot\left(6 n^{3}+9 n^{2}+n-1\right)= \\
& =\frac{n(n+1)}{6} \cdot(2 n+1)\left(3 n^{2}+3 n-1\right),
\end{aligned}
$$

ahonnan $S_{4}=\frac{n(n+1)(2 n+1)\left(3 n^{2}+3 n-1\right)}{30}$.

Tehát:

$$
S_{4}=1^{4}+2^{4}+3^{4}+\ldots+n^{4}=\frac{n(n+1)(2 n+1)\left(3 n^{2}+3 n-1\right)}{30} .
$$


Ha $p=5$, akkor az $S_{5}$-t megelőző $S_{i}$-ket felhasználva, a (3.3.1) összefüggésből kapjuk, hogy

$$
\begin{aligned}
& 6 \cdot S_{5}=(n+1)^{6}-\left(\begin{array}{l}
6 \\
2
\end{array}\right) \cdot S_{4}-\left(\begin{array}{l}
6 \\
3
\end{array}\right) \cdot S_{3}-\left(\begin{array}{l}
6 \\
4
\end{array}\right) \cdot S_{2}-\left(\begin{array}{l}
6 \\
5
\end{array}\right) \cdot S_{1}-\left(\begin{array}{l}
6 \\
6
\end{array}\right) \cdot(n+1)= \\
& =(n+1)^{6}-15 \cdot \frac{n(n+1)\left(6 n^{3}+9 n^{2}+n-1\right)}{30}-20 \cdot \frac{n^{2}(n+1)^{2}}{4}-15 \cdot \frac{n(n+1)(2 n+1)}{6}- \\
& -6 \cdot \frac{n(n+1)}{2}-(n+1) .
\end{aligned}
$$

Ezúttal $\frac{n+1}{2}$-t kiemelve, a műveletek elvégzése és az összevonások után kapjuk, hogy

$$
\begin{aligned}
& 6 \cdot S_{5}=\frac{n+1}{2} \cdot\left(2 n^{5}+4 n^{4}+n^{3}-n^{2}\right)=\frac{n^{2}(n+1)}{2} \cdot\left(2 n^{3}+4 n^{2}+n-1\right)= \\
& =\frac{n^{2}(n+1)}{2} \cdot(n+1)\left(2 n^{2}+2 n-1\right),
\end{aligned}
$$

ahonnan $S_{5}=\frac{n^{2}(n+1)^{2}\left(2 n^{2}+2 n-1\right)}{12}$.

Tehát:

$$
S_{5}=1^{5}+2^{5}+3^{5}+\ldots+n^{5}=\frac{n^{2}(n+1)^{2}\left(2 n^{2}+2 n-1\right)}{12} .
$$

A módszer nagy előnye, hogy az $S_{3}, S_{4}$ és $S_{5}$ összegek nem bonyolult és nem is hosszadalmas számításokkal viszonylag könnyen előállíthatók.

\subsection{3. Általánosítás a számtani sorozatok esetére a binomiális tételen alapuló módszer segítségével}

A fent leírt módszer segítségével elvégzünk egy általánosítást a számtani sorozatokra. Ehhez tekintsünk egy olyan $\left\{a_{n}\right\}_{n \geq 1}$ számtani sorozatot, melynek első eleme $a$, differenciája pedig $d$, ahol $a$ és $d$ valós számok. Vizsgáljuk meg, hogy mit lehet mondani a sorozat első $n$ tagja $p$ edik hatványának összegéről!

Legyen

$$
S_{p}(a, d)=a_{1}^{p}+a_{2}^{p}+a_{3}^{p}+\ldots+a_{n}^{p}=\sum_{i=1}^{n} a_{i}^{p}=\sum_{i=1}^{n}[a+(i-1) \cdot d]^{p},
$$

ahol $p=0 ; 1 ; 2 ; \ldots$.

Az $S_{0}(a, d)$ kiszámításával nem foglalkozunk külön, hiszen könnyen belátható hogy $S_{0}(a, d)=n$, mint ahogy azzal az esettel sem kell külön foglalkozni, amikor $d=0$, azaz a sorozat állandó, hiszen ilyenkor $S_{p}(a, 0)=n \cdot a_{1}^{p}=n \cdot a^{p}$.

Legyen tehát $d \neq 0$. Az alábbi gondolatmenet megegyezik az $S_{p}$ kiszámítására használt, már megismert eljárással. 
Ebben az esetben kiindulunk az

$a_{i+1}^{p+1}=\left(a_{i}+d\right)^{p+1}=a_{i}^{p+1}+\left(\begin{array}{c}p+1 \\ 1\end{array}\right) \cdot a_{i}^{p} \cdot d+\left(\begin{array}{c}p+1 \\ 2\end{array}\right) \cdot a_{i}^{p-1} \cdot d^{2}+\ldots+\left(\begin{array}{c}p+1 \\ p\end{array}\right) \cdot a_{i}^{1} \cdot d^{p}+\left(\begin{array}{c}p+1 \\ p+1\end{array}\right) \cdot d^{p+1}$

azonosságból, ahol $p \in N$ és $d \in R$, amelyet átrendezve kapjuk, hogy

$a_{i+1}^{p+1}-a_{i}^{p+1}=\left(\begin{array}{c}p+1 \\ 1\end{array}\right) \cdot a_{i}^{p} \cdot d+\left(\begin{array}{c}p+1 \\ 2\end{array}\right) \cdot a_{i}^{p-1} \cdot d^{2}+\ldots+\left(\begin{array}{c}p+1 \\ p\end{array}\right) \cdot a_{i}^{1} \cdot d^{p}+\left(\begin{array}{c}p+1 \\ p+1\end{array}\right) \cdot d^{p+1}$.

Ekkor

$$
\begin{aligned}
& \sum_{i=1}^{n}\left[a_{i+1}^{p+1}-a_{i}^{p+1}\right]=\sum_{i=1}^{n}\left[\left(\begin{array}{c}
p+1 \\
1
\end{array}\right) \cdot a_{i}^{p} \cdot d+\left(\begin{array}{c}
p+1 \\
2
\end{array}\right) \cdot a_{i}^{p-1} \cdot d^{2}+\ldots+\left(\begin{array}{c}
p+1 \\
p
\end{array}\right) \cdot a_{i}^{1} \cdot d^{p}+\left(\begin{array}{c}
p+1 \\
p+1
\end{array}\right) \cdot d^{p+1}\right]= \\
& =\left(\begin{array}{c}
p+1 \\
1
\end{array}\right) \cdot d \cdot \sum_{i=1}^{n} a_{i}^{p}+\left(\begin{array}{c}
p+1 \\
2
\end{array}\right) \cdot d^{2} \cdot \sum_{i=1}^{n} a_{i}^{p-1}+\ldots+\left(\begin{array}{c}
p+1 \\
p
\end{array}\right) \cdot d^{p} \cdot \sum_{i=1}^{n} a_{i}^{1}+\left(\begin{array}{c}
p+1 \\
p+1
\end{array}\right) \cdot d^{p+1} \cdot \sum_{i=0}^{n-1} 1
\end{aligned}
$$

A baloldalon egy teleszkópikus összeg található, amely az összevonások után nem lesz más, mint $a_{n+1}^{p+1}-a_{1}^{p+1}=(a+n d)^{p+1}-a^{p+1}$, vagyis

$$
(a+n d)^{p+1}-a^{p+1}=d \cdot\left(\begin{array}{c}
p+1 \\
1
\end{array}\right) \cdot S_{p}(a, d)+\ldots+d^{p} \cdot\left(\begin{array}{c}
p+1 \\
p
\end{array}\right) \cdot S_{1}(a, d)+d^{p+1} \cdot\left(\begin{array}{c}
p+1 \\
p+1
\end{array}\right) \cdot n .
$$

Figyelembe véve, hogy $S_{0}(a, d)=n$ és átrendezve az egyenlőséget

$$
\begin{aligned}
& d \cdot\left(\begin{array}{c}
p+1 \\
1
\end{array}\right) \cdot S_{p}(a, d)=(a+n d)^{p+1}-a^{p+1}-\sum_{k=2}^{p+1}\left[d^{k} \cdot\left(\begin{array}{c}
p+1 \\
k
\end{array}\right) \cdot S_{p+1-k}(a, d)\right]=(a+n d)^{p+1}-a^{p+1}- \\
& -d^{2} \cdot\left(\begin{array}{c}
p+1 \\
2
\end{array}\right) \cdot S_{p-1}(a, d)-\ldots-d^{p} \cdot\left(\begin{array}{c}
p+1 \\
p
\end{array}\right) \cdot S_{1}(a, d)-d^{p+1} \cdot\left(\begin{array}{c}
p+1 \\
p+1
\end{array}\right) \cdot S_{0}(a, d) \text {. }
\end{aligned}
$$

Felhasználva, hogy $\left(\begin{array}{c}p+1 \\ 1\end{array}\right)=p+1$ kapjuk, hogy

$$
\begin{aligned}
& (p+1) \cdot d \cdot S_{p}(a, d)=(a+n d)^{p+1}-a^{p+1}-\sum_{k=2}^{p+1}\left[d^{k} \cdot\left(\begin{array}{c}
p+1 \\
k
\end{array}\right) \cdot S_{p+1-k}(a, d)\right]=(a+n d)^{p+1}-a^{p+1}- \\
& -d^{2} \cdot\left(\begin{array}{c}
p+1 \\
2
\end{array}\right) \cdot S_{p-1}(a, d)-\ldots-d^{p} \cdot\left(\begin{array}{c}
p+1 \\
p
\end{array}\right) \cdot S_{1}(a, d)-d^{p+1} \cdot\left(\begin{array}{c}
p+1 \\
p+1
\end{array}\right) \cdot S_{0}(a, d),
\end{aligned}
$$

ahonnan

$$
S_{p}(a, d)=\frac{(a+n d)^{p+1}-a^{p+1}-d^{2} \cdot\left(\begin{array}{c}
p+1 \\
2
\end{array}\right) \cdot S_{p-1}(a, d)-\ldots-d^{p+1} \cdot\left(\begin{array}{c}
p+1 \\
p+1
\end{array}\right) \cdot S_{0}(a, d)}{(p+1) \cdot d} .
$$

Tehát:

$S_{p}(a, d)=\frac{(a+n d)^{p+1}-a^{p+1}-d^{2} \cdot\left(\begin{array}{c}p+1 \\ 2\end{array}\right) \cdot S_{p-1}(a, d)-\ldots-d^{p+1} \cdot\left(\begin{array}{c}p+1 \\ p+1\end{array}\right) \cdot S_{0}(a, d)}{(p+1) \cdot d}$

vagy 


$$
S_{p}(a, d)=\frac{(a+n d)^{p+1}-a^{p+1}-\sum_{k=2}^{p+1}\left[d^{k} \cdot\left(\begin{array}{c}
p+1 \\
k
\end{array}\right) \cdot S_{p+1-k}(a, d)\right]}{d \cdot(p+1)} .
$$

Végeredményben ismételten egy hasznos formulát tudtunk adni a hatványösszegekre, és az is belátható, hogy az $S_{p}(a, d)$ kiszámításához - akárcsak az $S_{i}$ összegek esetén - ezúttal is szükség van az előző, azaz az $S_{1}(a, d), S_{2}(a, d), \ldots, S_{p-1}(a, d)$ összegekre vonatkozó eredményekre.

A továbbiakban lássunk a formula alkalmazására néhány érdekes példát.

\subsubsection{Speciális esetek a számtani sorozatokra vonatkozóan kapott rekurziós összefüggésre}

A speciális esetek vizsgálatát logikailag a következőképpen végezzük: a $d=1 ; 2 ; 3$-ra történik a fö felosztás, majd ezen belül megnézzük a kitevők $p=1 ; 2 ; 3$ eseteit, $\mathrm{s}$ harmadikként ez utóbbiakon belül felírjuk az $a=1 ; 2 ; n+1$ eseteket.

Legyen tehát először $d=1$, ekkor:

$$
\begin{aligned}
& S_{p}(a, 1)=\frac{(a+n)^{p+1}-a^{p+1}-\sum_{k=2}^{p+1}\left[1^{k} \cdot\left(\begin{array}{c}
p+1 \\
k
\end{array}\right) \cdot S_{p+1-k}(a, 1)\right]}{1 \cdot(p+1)}= \\
& =\frac{(a+n)^{p+1}-a^{p+1}-\sum_{k=2}^{p+1}\left[\left(\begin{array}{c}
p+1 \\
k
\end{array}\right) \cdot S_{p+1-k}(a, 1)\right]}{p+1} .
\end{aligned}
$$

Figyeljük meg, hogy mit kapunk eredményül néhány konkrét $p$ érték esetén!

Ha $p=1$, akkor

$$
S_{1}(a, 1)=\frac{(a+n)^{2}-a^{2}-\left(\begin{array}{l}
2 \\
2
\end{array}\right) \cdot S_{0}(a, 1)}{2}=\frac{a^{2}+2 a n+n^{2}-a^{2}-n}{2}=\frac{n(2 a-1+n)}{2},
$$

$\operatorname{azaz} S_{1}(a, 1)=a+(a+1)+\ldots+(a+n-1)=\frac{n}{2} \cdot(n+2 a-1)$.

Ezen belül speciális esetek:

Ha $a=1$, akkor $S_{1}(1,1)=S_{1}=1+2+\ldots+n=\frac{n(n+1)}{2}$.

Ha $a=2$, akkor $S_{1}(2,1)=2+3+\ldots+(n+1)=\frac{n(n+3)}{2}$.

Ha $a=n+1$, akkor $S_{1}(n+1,1)=(n+1)+(n+2)+\ldots+(2 n)=\frac{n(3 n+1)}{2}$. 


\section{Megjegyzés}

Szemléletes bizonyítás az $S_{1}(1,1)$ kiszámítására (3.3.1. ábra):

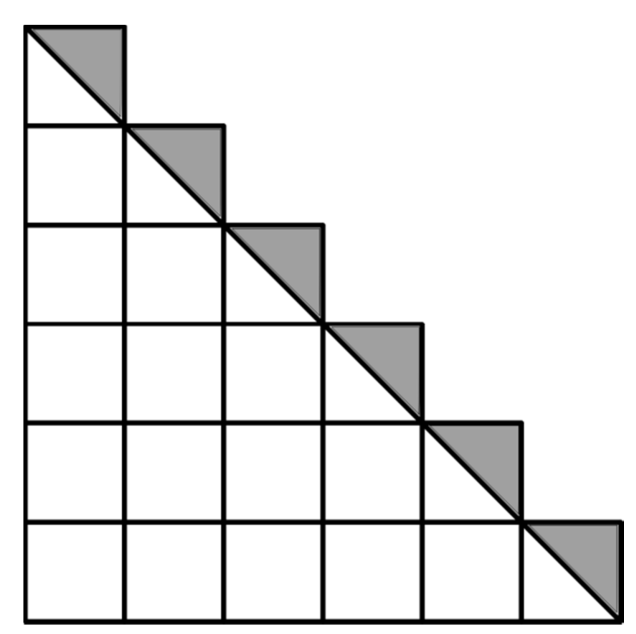

$$
1+2+\ldots+n=\frac{n^{2}}{2}+\frac{n}{2}
$$

\subsection{1. ábra}

Ha $p=2$, akkor

$$
S_{2}(a, 1)=\frac{(a+n)^{3}-a^{3}-\left(\begin{array}{l}
3 \\
2
\end{array}\right) \cdot S_{1}(a, 1)-\left(\begin{array}{l}
3 \\
3
\end{array}\right) \cdot S_{0}(a, 1)}{3}=
$$

$=\frac{3 a^{2} n+3 a n^{2}+n^{3}-3 \cdot \frac{n}{2} \cdot(n+2 a-1)-n}{3}=\frac{n}{6} \cdot\left[2 n^{2}+3 n(2 a-1)+6 a^{2}-6 a+1\right]$,

$\operatorname{azaz} S_{2}(a, 1)=a^{2}+(a+1)^{2}+\ldots+(a+n-1)^{2}=\frac{n}{6} \cdot\left[2 n^{2}+3 n(2 a-1)+6 a^{2}-6 a+1\right]$.

Itt a speciális esetek a következők:

Ha $a=1$, akkor $S_{2}(1,1)=S_{2}=1^{2}+2^{2}+\ldots+n^{2}=\frac{n}{6} \cdot\left(2 n^{2}+3 n+1\right)=\frac{n(n+1)(2 n+1)}{6}$.

Ha $a=2$, akkor $S_{2}(2,1)=2^{2}+3^{2}+\ldots+(n+1)^{2}=\frac{n}{6} \cdot\left(2 n^{2}+9 n+13\right)$.

Ha $a=n+1$, akkor

$$
S_{2}(n+1,1)=(n+1)^{2}+(n+2)^{2}+\ldots+(2 n)^{2}=\frac{n}{6} \cdot\left(14 n^{2}+9 n+1\right)=\frac{n(2 n+1)(7 n+1)}{6} .
$$

Ha $p=3$, akkor

$$
S_{3}(a, 1)=\frac{(a+n)^{4}-a^{4}-\left(\begin{array}{l}
4 \\
2
\end{array}\right) \cdot S_{2}(a, 1)-\left(\begin{array}{l}
4 \\
3
\end{array}\right) \cdot S_{1}(a, 1)-\left(\begin{array}{l}
4 \\
4
\end{array}\right) \cdot S_{0}(a, 1)}{4}=
$$


$=\frac{4 a^{3} n+6 a^{2} n^{2}+4 a n^{3}+n^{4}-6 \cdot \frac{n}{6} \cdot\left[2 n^{2}+3 n(2 a-1)+6 a^{2}-6 a+1\right]-4 \cdot \frac{n}{2} \cdot(n+2 a-1)-n}{4}$.

A zárójelek felbontása és az összevonások után kapjuk, hogy

$$
S_{3}(a, 1)=\frac{n}{4} \cdot\left[n^{3}+2 n^{2}(2 a-1)+n\left(6 a^{2}-6 a+1\right)+4 a^{3}-6 a^{2}+2 a\right]
$$

azaz

$$
S_{3}(a, 1)=a^{3}+(a+1)^{3}+\ldots+(a+n-1)^{3}=\frac{n}{4} \cdot\left[n^{3}+2 n^{2}(2 a-1)+n\left(6 a^{2}-6 a+1\right)+4 a^{3}-6 a^{2}+2 a\right] .
$$

Ezen felírás speciális esetei:

Ha $a=1$, akkor $S_{3}(1,1)=S_{3}=1^{3}+2^{3}+\ldots+n^{3}=\frac{n}{4} \cdot\left(n^{3}+2 n^{2}+n\right)=\frac{n^{2}(n+1)^{2}}{4}$.

Ha $a=2$, akkor

$$
S_{3}(2,1)=2^{3}+3^{3}+\ldots+(n+1)^{3}=\frac{n}{4} \cdot\left(n^{3}+6 n^{2}+13 n+12\right)=\frac{n(n+3)\left(n^{2}+3 n+4\right)}{4} .
$$

Ha $a=n+1$, akkor

$$
S_{3}(n+1,1)=(n+1)^{3}+(n+2)^{3}+\ldots+(2 n)^{3}=\frac{n^{2}}{4} \cdot\left(15 n^{2}+14 n+3\right)=\frac{n^{2}(3 n+1)(5 n+3)}{4} .
$$

Legyen $d=2$, ekkor az összefüggésünk az alábbi alakot ölti:

$$
S_{p}(a, 2)=\frac{(a+2 n)^{p+1}-a^{p+1}-\sum_{k=2}^{p+1}\left[2^{k} \cdot\left(\begin{array}{c}
p+1 \\
k
\end{array}\right) \cdot S_{p+1-k}(a, 2)\right]}{2 \cdot(p+1)} .
$$

Ez esetben is figyeljük meg, hogy mit kapunk eredményül néhány konkrét $p$ érték mellett!

Ha $p=1$, akkor

$$
\begin{aligned}
& S_{1}(a, 2)=\frac{(a+2 n)^{2}-a^{2}-2^{2} \cdot\left(\begin{array}{l}
2 \\
2
\end{array}\right) \cdot S_{0}(a, 2)}{2 \cdot 2}=\frac{a^{2}+4 a n+4 n^{2}-a^{2}-4 n}{4}=n(n+a-1), \\
& \text { azaz } S_{1}(a, 2)=a+(a+2)+\ldots+(a+2 n-2)=n(n+a-1) .
\end{aligned}
$$

Ekkor a speciális esetek az alábbiak szerint következnek:

Ha $a=1$, akkor $S_{1}(1,2)=1+3+\ldots+(2 n-1)=n^{2}$.

Ha $a=2$, akkor $S_{1}(2,2)=2+4+\ldots+(2 n)=n(n+1)$.

Ha $a=n+1$, akkor $S_{1}(n+1,2)=(n+1)+(n+3)+\ldots+(3 n-1)=2 n^{2}$. 


\section{Megjegyzés}

Szemléletes bizonyítás az $S_{1}(1,2)$ kiszámítására (3.3.2. ábra):

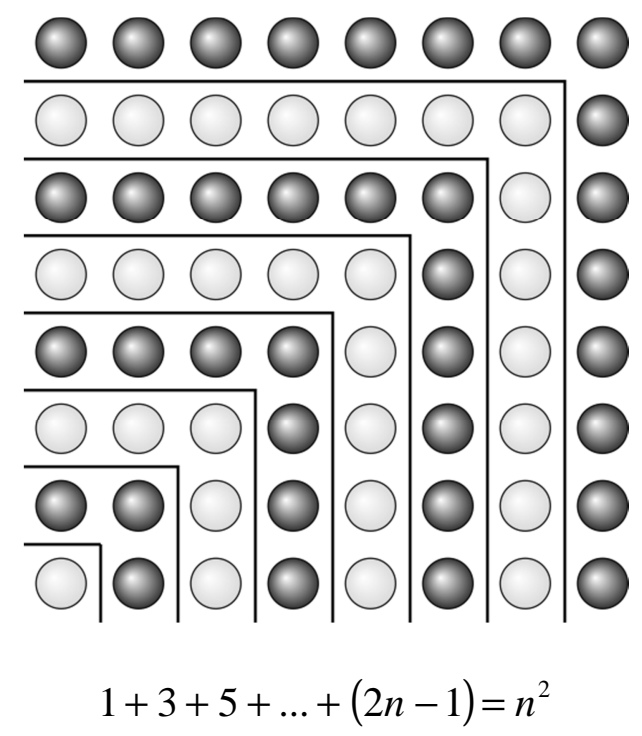

\subsection{2. ábra}

\section{Megjegyzés}

Az $S_{1}(a, 2)$ eredményének felhasználásával a pozitív páratlan számokhoz kapcsolódóan két igen érdekes tulajdonság bizonyítható egyszerủen, éspedig:

1) az első $n$ darab pozitív páratlan szám összegének és $(n+1)$-töl kezdödően minden második szám (szintén n darab) összegének aránya állandó.

Azt kell belátnunk, hogy az $\frac{1+3+\ldots+(2 n-1)}{(n+1)+(n+3)+\ldots+(3 n-1)}$ tört értéke minden pozitív egész $n$ esetén állandó. Mivel

$\frac{1+3+\ldots+(2 n-1)}{(n+1)+(n+3)+\ldots+(3 n-1)}=\frac{S_{1}(1,2)}{S_{1}(n+1,2)}=\frac{n(n+1-1)}{n(n+n+1-1)}=\frac{n}{2 n}=\frac{1}{2}$,

így tehát az állandó értéke $\frac{1}{2}$.

2) az első $2 n$ darab pozitív páratlan egész szám esetén, az első n darab szám összegének és az utolsó $n$ darab szám összegének aránya állandó.

Tehát azt kell belátnunk, hogy az $\frac{1+3+\ldots+(2 n-1)}{(2 n+1)+(2 n+3)+\ldots+(4 n-1)}$ tört értéke minden pozitív egész $n$ esetén állandó. Ez könnyen bizonyítható, mivel

$$
\frac{1+3+\ldots+(2 n-1)}{(2 n+1)+(2 n+3)+\ldots+(4 n-1)}=\frac{S_{1}(1,2)}{S_{1}(2 n+1,2)}=\frac{n(n+1-1)}{n(n+2 n+1-1)}=\frac{n}{3 n}=\frac{1}{3} \text {, }
$$

azaz a keresett állandó értéke $\frac{1}{3}$ lesz.

A pozitív páratlan számok ez utóbbi tulajdonságának szemléletes bizonyítása (3.3.3. ábra): 

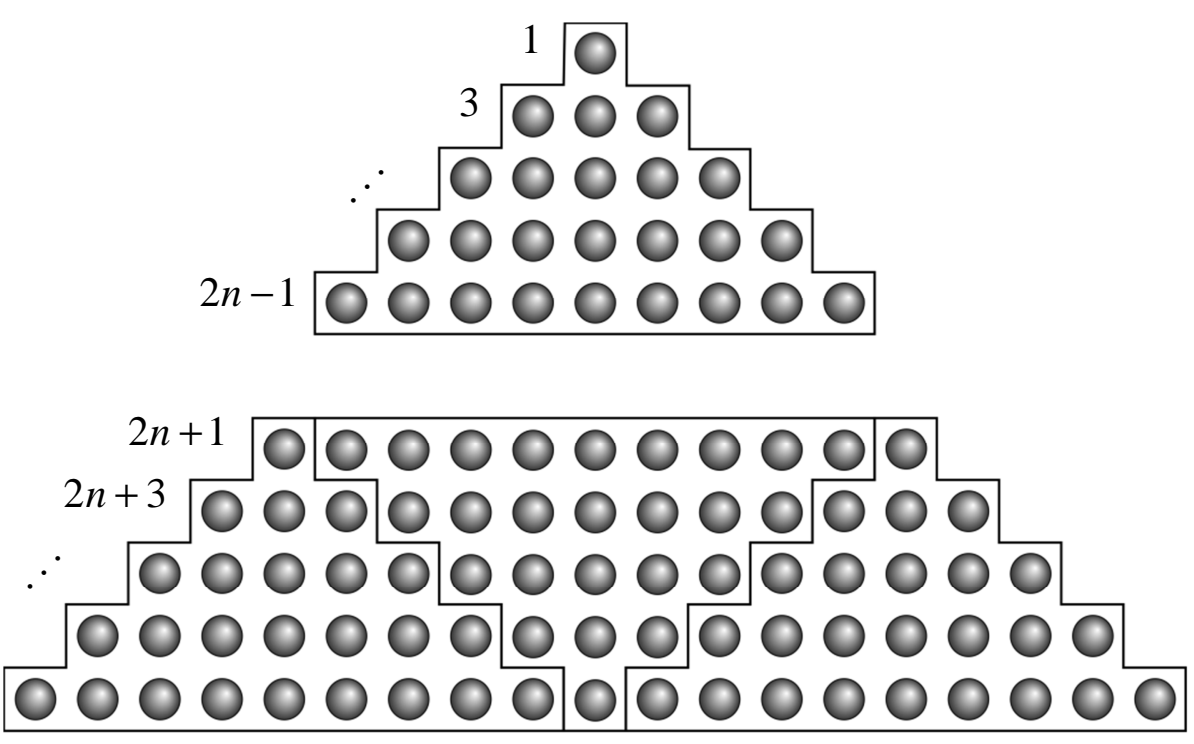

$$
\frac{1+3+\ldots+(2 n-1)}{(2 n+1)+(2 n+3)+\ldots+(4 n-1)}=\frac{1}{3}
$$

3.3.3. ábra

Ha $p=2$, akkor

$$
\begin{aligned}
& S_{2}(a, 2)=\frac{(a+2 n)^{3}-a^{3}-2^{2} \cdot\left(\begin{array}{l}
3 \\
2
\end{array}\right) \cdot S_{1}(a, 2)-2^{3} \cdot\left(\begin{array}{l}
3 \\
3
\end{array}\right) \cdot S_{0}(a, 2)}{2 \cdot 3}= \\
& =\frac{6 a^{2} n+12 a n^{2}+8 n^{3}-12 n(n+a-1)-8 n}{6}=\frac{n}{3} \cdot\left[4 n^{2}+6 n(a-1)+3 a^{2}-6 a+2\right],
\end{aligned}
$$

$\operatorname{azaz} S_{2}(a, 2)=a^{2}+(a+2)^{2}+\ldots+(a+2 n-2)^{2}=\frac{n}{3} \cdot\left[4 n^{2}+6 n(a-1)+3 a^{2}-6 a+2\right]$.

E változat speciális esetei:

Ha $a=1$, akkor $S_{2}(1,2)=1^{2}+3^{2}+\ldots+(2 n-1)^{2}=\frac{n}{3} \cdot\left(4 n^{2}-1\right)=\frac{n(2 n+1)(2 n-1)}{3}$.

Ha $a=2$, akkor $S_{2}(2,2)=2^{2}+4^{2}+\ldots+(2 n)^{2}=\frac{n}{3} \cdot\left(4 n^{2}+6 n+2\right)=\frac{2 n(n+1)(2 n+1)}{3}$.

Ha $a=n+1$, akkor $S_{2}(n+1,2)=(n+1)^{2}+(n+3)^{2}+\ldots+(3 n-1)^{2}=\frac{n}{3} \cdot\left(13 n^{2}-1\right)$.

Ha $p=3$, akkor

$$
\begin{aligned}
& S_{3}(a, 2)=\frac{(a+2 n)^{4}-a^{4}-2^{2} \cdot\left(\begin{array}{l}
4 \\
2
\end{array}\right) \cdot S_{2}(a, 2)-2^{3} \cdot\left(\begin{array}{l}
4 \\
3
\end{array}\right) \cdot S_{1}(a, 2)-2^{4} \cdot\left(\begin{array}{l}
4 \\
4
\end{array}\right) \cdot S_{0}(a, 2)}{2 \cdot 4}= \\
& =\frac{8 a^{3} n+24 a^{2} n^{2}+32 a n^{3}+16 n^{4}-8 n\left[4 n^{2}+6 n(a-1)+3 a^{2}-6 a+2\right]-32 n(n+a-1)-16 n}{8} .
\end{aligned}
$$


A zárójelek felbontása és az összevonások után, $n$ hatványai szerint rendezve kapjuk, hogy

$S_{3}(a, 2)=n\left[2 n^{3}+4 n^{2}(a-1)+n\left(3 a^{2}-6 a+2\right)+a^{3}-3 a^{2}+2 a\right]$,

azaz

$S_{3}(a, 2)=a^{3}+(a+2)^{3}+\ldots+(a+2 n-2)^{3}=$

$=n\left[2 n^{3}+4 n^{2}(a-1)+n\left(3 a^{2}-6 a+2\right)+a^{3}-3 a^{2}+2 a\right]$.

Itt a speciális esetekre vonatkozó „elágazások” az alábbiak:

Ha $a=1$, akkor $S_{3}(1,2)=1^{3}+3^{3}+\ldots+(2 n-1)^{3}=n\left(2 n^{3}-n\right)=n^{2}\left(2 n^{2}-1\right)$.

Ha $a=2$, akkor $S_{3}(2,2)=2^{3}+4^{3}+\ldots+(2 n)^{3}=n\left(2 n^{3}+4 n^{2}+2 n\right)=2 n^{2}(n+1)^{2}$.

Ha $a=n+1$, akkor $S_{3}(n+1,2)=(n+1)^{3}+(n+3)^{3}+\ldots+(3 n-1)^{3}=2 n^{2}\left(5 n^{2}-1\right)$.

Legyen $d=3$. Ennél a változatnál az összefüggés az alábbi lesz:

$S_{p}(a, 3)=\frac{(a+3 n)^{p+1}-a^{p+1}-\sum_{k=2}^{p+1}\left[3^{k} \cdot\left(\begin{array}{c}p+1 \\ k\end{array}\right) \cdot S_{p+1-k}(a, 3)\right]}{3 \cdot(p+1)}$.

Ebben az esetben az első három pozitív egész $p$ értékre vonatkozóan a következő eredményeket kapjuk:

Ha $p=1$, akkor

$S_{1}(a, 3)=\frac{(a+3 n)^{2}-a^{2}-3^{2} \cdot\left(\begin{array}{l}2 \\ 2\end{array}\right) \cdot S_{0}(a, 3)}{3 \cdot 2}=\frac{a^{2}+6 a n+9 n^{2}-a^{2}-9 n}{6}=\frac{n(3 n+2 a-3)}{2}$,

$\operatorname{azaz} S_{1}(a, 3)=a+(a+3)+\ldots+(a+3 n-3)=\frac{n}{2} \cdot(3 n+2 a-3)$.

Az ide tartozó három speciális eset:

Ha $a=1$, akkor $S_{1}(1,3)=1+4+\ldots+(3 n-2)=\frac{n(3 n-1)}{2}$.

Ha $a=2$, akkor $S_{1}(2,3)=2+5+\ldots+(3 n-1)=\frac{n(3 n+1)}{2}$.

Ha $a=n+1$, akkor $S_{1}(n+1,3)=(n+1)+(n+4)+\ldots+(4 n-2)=\frac{n(5 n-1)}{2}$.

Ha $p=2$, akkor

$S_{2}(a, 3)=\frac{(a+3 n)^{3}-a^{3}-3^{2} \cdot\left(\begin{array}{l}3 \\ 2\end{array}\right) \cdot S_{1}(a, 3)-3^{3} \cdot\left(\begin{array}{l}3 \\ 3\end{array}\right) \cdot S_{0}(a, 3)}{3 \cdot 3}=$ 
$=\frac{9 a^{2} n+27 a n^{2}+27 n^{3}-27 \cdot \frac{n(3 n+2 a-3)}{2}-27 n}{9}=\frac{n}{2} \cdot\left[6 n^{2}+3 n(2 a-3)+2 a^{2}-6 a+3\right]$,

azaz $S_{2}(a, 3)=a^{2}+(a+3)^{2}+\ldots+(a+3 n-3)^{2}=\frac{n}{2} \cdot\left[6 n^{2}+3 n(2 a-3)+2 a^{2}-6 a+3\right]$.

Ennek speciális változatai:

Ha $a=1$, akkor $S_{2}(1,3)=1^{2}+4^{2}+\ldots+(3 n-2)^{2}=\frac{n}{2} \cdot\left(6 n^{2}-3 n-1\right)$.

Ha $a=2$, akkor $S_{2}(2,3)=2^{2}+5^{2}+\ldots+(3 n-1)^{2}=\frac{n}{2} \cdot\left(6 n^{2}+3 n-1\right)$.

Ha $a=n+1$, akkor

$$
S_{2}(n+1,3)=(n+1)^{2}+(n+4)^{2}+\ldots+(4 n-2)^{2}=\frac{n}{2} \cdot\left(14 n^{2}-5 n-1\right)=\frac{n(2 n-1)(7 n+1)}{2} .
$$

S végül, ha $p=3$, akkor

$S_{3}(a, 3)=\frac{(a+3 n)^{4}-a^{4}-3^{2} \cdot\left(\begin{array}{l}4 \\ 2\end{array}\right) \cdot S_{2}(a, 3)-3^{3} \cdot\left(\begin{array}{l}4 \\ 3\end{array}\right) \cdot S_{1}(a, 3)-3^{4} \cdot\left(\begin{array}{l}4 \\ 4\end{array}\right) \cdot S_{0}(a, 3)}{3 \cdot 4}=$
$=\frac{12 a^{3} n+54 a^{2} n^{2}+108 a n^{3}+81 n^{4}-27 n\left[6 n^{2}+3 n(2 a-3)+2 a^{2}-6 a+3\right]-54 n(3 n+2 a-3)-81 n}{12}$.

A mủveletek elvégzése és az összevonások után, ismét $n$ hatványai szerint rendezünk. Így

$S_{3}(a, 3)=\frac{n}{4} \cdot\left[27 n^{3}+18 n^{2}(2 a-3)+9 n\left(2 a^{2}-6 a+3\right)+4 a^{3}-18 a^{2}+18 a\right]$,

azaz

$$
\begin{aligned}
& S_{3}(a, 3)=a^{3}+(a+3)^{3}+\ldots+(a+3 n-3)^{3}= \\
& =\frac{n}{4} \cdot\left[27 n^{3}+18 n^{2}(2 a-3)+9 n\left(2 a^{2}-6 a+3\right)+4 a^{3}-18 a^{2}+18 a\right] .
\end{aligned}
$$

Az ehhez tartozó speciális esetek a következők:

Ha $a=1$, akkor

$$
S_{3}(1,3)=1^{3}+4^{3}+\ldots+(3 n-2)^{3}=\frac{n}{4} \cdot\left(27 n^{3}-18 n^{2}-9 n+4\right)=\frac{n(3 n-1)\left(9 n^{2}-3 n-4\right)}{4} .
$$

Ha $a=2$, akkor

$$
S_{3}(2,3)=2^{3}+5^{3}+\ldots+(3 n-1)^{3}=\frac{n}{4} \cdot\left(27 n^{3}+18 n^{2}-9 n-4\right)=\frac{n(3 n+1)\left(9 n^{2}+3 n-4\right)}{4} .
$$

Ha $a=n+1$, akkor

$$
\begin{aligned}
& S_{3}(n+1,3)=(n+1)^{3}+(n+4)^{3}+\ldots+(4 n-2)^{3}=\frac{n}{4} \cdot\left(85 n^{3}-42 n^{2}-15 n+4\right)= \\
& =\frac{n(5 n-1)\left(17 n^{2}-5 n-4\right)}{4}
\end{aligned}
$$


Habár „csak” a legkisebb pozitív $d$-kre, $p$-kre és három $a$-ra írtunk fel összesen 27 esetet, mégis több nevezetes összegképlet ,köszönt vissza”. Például, hogy az első $n$ darab pozitív páratlan szám összege teljes négyzet, az első $n$ darab pozitív páros szám köbeinek összege egy teljes négyzet kétszerese stb. További $d$-kre, $p$-kre és $a$-kra felírva az összegzési képleteket újabb szép összefüggéseket lehetne meghatározni.

\subsubsection{A binomiális tételen alapuló módszer alkalmazása alternáló összeg esetére}

Az első módszer leírásánál a 3.1.3. fejezetben már volt szó az első $n$ pozitív egész szám $p$ edik hatványa váltakozó előjelü összegének kiszámításáról, vagyis az

$$
S_{p}^{*}=1^{p}-2^{p}+3^{p}-4^{p}+\ldots+(-1)^{n-1} \cdot n^{p}=\sum_{k=1}^{n}(-1)^{k-1} \cdot k^{p}
$$

összeg meghatározásáról. A megjelölt fejezetben két módszert is bemutattunk az ezen összegek kiszámításához szükséges rekurziók felírására.

A továbbiakban egy újabb módszert mutatunk be az $S_{p}^{*}$ kiszámítására, amelynek gondolatmenete hasonlít a 3.3.1. fejezetben ismertetetthez, az $S_{p}$ kiszámításánál bemutatottra. Itt is egy rekurziós összefüggést állítunk fel, ezúttal az $S_{p}^{*}$ kifejezések között. Vagyis az eredményekhez - akárcsak a 3.1.3. fejezetben bemutatott egyik módszer esetén - a most tárgyalandó metodikánál sincs szükség az $S_{p}$ sorozat tagjaira.

Legyen $p \in N$ és $a \in R$. A levezetéshez induljunk ki az

$$
(a+2)^{p+1}-a^{p+1}=\left(\begin{array}{c}
p+1 \\
1
\end{array}\right) \cdot a^{p} \cdot 2+\left(\begin{array}{c}
p+1 \\
2
\end{array}\right) \cdot a^{p-1} \cdot 2^{2}+\ldots+\left(\begin{array}{c}
p+1 \\
p
\end{array}\right) \cdot a^{1} \cdot 2^{p}+\left(\begin{array}{c}
p+1 \\
p+1
\end{array}\right) \cdot 2^{p+1}
$$

azonosságból és helyettesítsük be az $a$ helyére rendre a természetes számokat 1-től $n$-ig. Ekkor adódik, hogy

$$
\begin{aligned}
& 3^{p+1}-1^{p+1}=\left(\begin{array}{c}
p+1 \\
1
\end{array}\right) \cdot 1^{p} \cdot 2+\left(\begin{array}{c}
p+1 \\
2
\end{array}\right) \cdot 1^{p-1} \cdot 2^{2}+\ldots+\left(\begin{array}{c}
p+1 \\
p
\end{array}\right) \cdot 1^{1} \cdot 2^{p}+\left(\begin{array}{c}
p+1 \\
p+1
\end{array}\right) \cdot 2^{p+1} \\
& 4^{p+1}-2^{p+1}=\left(\begin{array}{c}
p+1 \\
1
\end{array}\right) \cdot 2^{p} \cdot 2+\left(\begin{array}{c}
p+1 \\
2
\end{array}\right) \cdot 2^{p-1} \cdot 2^{2}+\ldots+\left(\begin{array}{c}
p+1 \\
p
\end{array}\right) \cdot 2^{1} \cdot 2^{p}+\left(\begin{array}{c}
p+1 \\
p+1
\end{array}\right) \cdot 2^{p+1} \\
& 5^{p+1}-3^{p+1}=\left(\begin{array}{c}
p+1 \\
1
\end{array}\right) \cdot 3^{p} \cdot 2+\left(\begin{array}{c}
p+1 \\
2
\end{array}\right) \cdot 3^{p-1} \cdot 2^{2}+\ldots+\left(\begin{array}{c}
p+1 \\
p
\end{array}\right) \cdot 3^{1} \cdot 2^{p}+\left(\begin{array}{c}
p+1 \\
p+1
\end{array}\right) \cdot 2^{p+1} \\
& 6^{p+1}-4^{p+1}=\left(\begin{array}{c}
p+1 \\
1
\end{array}\right) \cdot 4^{p} \cdot 2+\left(\begin{array}{c}
p+1 \\
2
\end{array}\right) \cdot 4^{p-1} \cdot 2^{2}+\ldots+\left(\begin{array}{c}
p+1 \\
p
\end{array}\right) \cdot 4^{1} \cdot 2^{p}+\left(\begin{array}{c}
p+1 \\
p+1
\end{array}\right) \cdot 2^{p+1}
\end{aligned}
$$

$$
\begin{aligned}
& (n+1)^{p+1}-(n-1)^{p+1}=\left(\begin{array}{c}
p+1 \\
1
\end{array}\right) \cdot(n-1)^{p} \cdot 2+\left(\begin{array}{c}
p+1 \\
2
\end{array}\right) \cdot(n-1)^{p-1} \cdot 2^{2}+\ldots+\left(\begin{array}{c}
p+1 \\
p+1
\end{array}\right) \cdot 2^{p+1} \\
& (n+2)^{p+1}-n^{p+1}=\left(\begin{array}{c}
p+1 \\
1
\end{array}\right) \cdot n^{p} \cdot 2+\left(\begin{array}{c}
p+1 \\
2
\end{array}\right) \cdot n^{p-1} \cdot 2^{2}+\ldots+\left(\begin{array}{c}
p+1 \\
p
\end{array}\right) \cdot n^{1} \cdot 2^{p}+\left(\begin{array}{c}
p+1 \\
p+1
\end{array}\right) \cdot 2^{p+1}
\end{aligned}
$$


Szorozzuk meg a felírt összefüggéseket felváltva 1-gyel és (-1)-gyel (az elsőt 1-gyel szorozva), majd összegezzük az így kapottakat. Így a baloldalon egy teleszkópikus összeghez jutunk és az összevonások után a következő eredményeket kapjuk:

Ha $n$ páros, akkor $(n+1)^{p+1}-1-(n+2)^{p+1}+2^{p+1}=\left(\begin{array}{c}p+1 \\ 1\end{array}\right) \cdot S_{p}^{*} \cdot 2+\left(\begin{array}{c}p+1 \\ 2\end{array}\right) \cdot S_{p-1}^{*} \cdot 2^{2}+\ldots+\left(\begin{array}{c}p+1 \\ p\end{array}\right) \cdot S_{1}^{*} \cdot 2^{p}$, amelyet átrendezve és felhasználva a $\left(\begin{array}{c}p+1 \\ 1\end{array}\right)=p+1$ egyenlőséget, kapjuk hogy $2 \cdot(p+1) \cdot S_{p}^{*}=(n+1)^{p+1}-1-(n+2)^{p+1}+2^{p+1}-\left(\begin{array}{c}p+1 \\ 2\end{array}\right) \cdot S_{p-1}^{*} \cdot 2^{2}-\ldots-\left(\begin{array}{c}p+1 \\ p\end{array}\right) \cdot S_{1}^{*} \cdot 2^{p}$.

Ha $n$ páratlan, akkor $(n+2)^{p+1}-1-(n+1)^{p+1}+2^{p+1}=\left(\begin{array}{c}p+1 \\ 1\end{array}\right) \cdot S_{p}^{*} \cdot 2+\left(\begin{array}{c}p+1 \\ 2\end{array}\right) \cdot S_{p-1}^{*} \cdot 2^{2}+\ldots+\left(\begin{array}{c}p+1 \\ p\end{array}\right) \cdot S_{1}^{*} \cdot 2^{p}+2^{p+1}$, amelyet szintén átrendezve és itt is felhasználva a $\left(\begin{array}{c}p+1 \\ 1\end{array}\right)=p+1$ egyenlőséget, adódik hogy $2 \cdot(p+1) \cdot S_{p}^{*}=(n+2)^{p+1}-1-(n+1)^{p+1}-\left(\begin{array}{c}p+1 \\ 2\end{array}\right) \cdot S_{p-1}^{*} \cdot 2^{2}-\ldots-\left(\begin{array}{c}p+1 \\ p\end{array}\right) \cdot S_{1}^{*} \cdot 2^{p}$.

Összegezve:

$$
\begin{aligned}
& 2 \cdot(p+1) \cdot S_{p}^{*}=(-1)^{n-1} \cdot\left[(n+2)^{p+1}-(n+1)^{p+1}-2^{p}\right]+2^{p}-1- \\
& -\left(\begin{array}{c}
p+1 \\
2
\end{array}\right) \cdot S_{p-1}^{*} \cdot 2^{2}-\left(\begin{array}{c}
p+1 \\
3
\end{array}\right) \cdot S_{p-2}^{*} \cdot 2^{3}-\ldots-\left(\begin{array}{c}
p+1 \\
p
\end{array}\right) \cdot S_{1}^{*} \cdot 2^{p},
\end{aligned}
$$

ami másképpen felírva

$$
2 \cdot(p+1) \cdot S_{p}^{*}=(-1)^{n-1} \cdot\left[(n+2)^{p+1}-(n+1)^{p+1}-2^{p}\right]+2^{p}-1-\sum_{k=2}^{p}\left(\begin{array}{c}
p+1 \\
k
\end{array}\right) \cdot S_{p+1-k}^{*} \cdot 2^{k}
$$

egyenlőségbe megy át.

Mint látható, ezúttal is egy olyan rekurziós összefüggést kaptunk, ahol az $S_{p}^{*}$ kiszámítása az $S_{1}^{*}, S_{2}^{*}, \ldots, S_{p-1}^{*}$ összegekre vonatkozó eredmények felhasználásával történhet.

A továbbiakban alkalmazva a 3.1.4. fejezetben levezetett, az $S_{1}^{*}$ és $S_{2}^{*}$ összegekre megadott eredményeket, a (3.3.5) összefüggés alapján kiszámítjuk az $S_{3}^{*}$ és $S_{4}^{*}$ összegeket.

\subsubsection{Az alternáló összegre kapott összefüggés speciális esetei}

E részfejezetben az alternáló összegre levezetett rekurziós képlet segítségével két konkrét esetet mutatunk be, éspedig a $p=3$ és $p=4$ eseteket. 
Ha $p=3$, akkor

$$
\begin{aligned}
& 2 \cdot 4 \cdot S_{3}^{*}=(-1)^{n-1} \cdot\left[(n+2)^{4}-(n+1)^{4}-2^{3}\right]+2^{3}-1-\left(\begin{array}{l}
4 \\
2
\end{array}\right) \cdot S_{2}^{*} \cdot 2^{2}-\left(\begin{array}{l}
4 \\
3
\end{array}\right) \cdot S_{1}^{*} \cdot 2^{3}= \\
& =(-1)^{n-1} \cdot\left(n^{4}+8 n^{3}+24 n^{2}+32 n+16-n^{4}-4 n^{3}-6 n^{2}-4 n-1-8\right)+7- \\
& -24 \cdot(-1)^{n-1} \cdot \frac{n(n+1)}{2}-32 \cdot \frac{(-1)^{n-1} \cdot(2 n+1)+1}{4} .
\end{aligned}
$$

A zárójelek felbontása, az összevonások és a megfelelő csoportosítások után, kapjuk hogy

$8 \cdot S_{3}^{*}=(-1)^{n-1} \cdot\left(4 n^{3}+6 n^{2}-1\right)-1$.

Tehát:

$$
S_{3}^{*}=\frac{(-1)^{n-1} \cdot\left(4 n^{3}+6 n^{2}-1\right)-1}{8} .
$$

Említsük meg, hogy az $S_{3}^{*}$ átírható $S_{3}^{*}=\frac{(-1)^{n-1} \cdot(2 n+1)\left(2 n^{2}+2 n-1\right)-1}{8}$ alakra is.

Ha $p=4$, akkor

$$
\begin{aligned}
& 2 \cdot 5 \cdot S_{4}^{*}=(-1)^{n-1} \cdot\left[(n+2)^{5}-(n+1)^{5}-2^{4}\right]+2^{4}-1-\left(\begin{array}{l}
5 \\
2
\end{array}\right) \cdot S_{3}^{*} \cdot 2^{2}-\left(\begin{array}{l}
5 \\
3
\end{array}\right) \cdot S_{2}^{*} \cdot 2^{3}-\left(\begin{array}{l}
5 \\
4
\end{array}\right) \cdot S_{1}^{*} \cdot 2^{4}= \\
& =(-1)^{n-1} \cdot\left(n^{5}+10 n^{4}+40 n^{3}+80 n^{2}+80 n+32-n^{5}-5 n^{4}-10 n^{3}-10 n^{2}-5 n-1-16\right)+15- \\
& -40 \cdot \frac{(-1)^{n-1} \cdot\left(4 n^{3}+6 n^{2}-1\right)-1}{8}-80 \cdot(-1)^{n-1} \cdot \frac{n(n+1)}{2}-80 \cdot \frac{(-1)^{n-1} \cdot(2 n+1)+1}{4} .
\end{aligned}
$$

A műveletek elvégzése és az összevonások után a következő összefüggéshez jutunk:

$10 \cdot S_{4}^{*}=(-1)^{n-1} \cdot\left(5 n^{4}+10 n^{3}-5 n\right)=(-1)^{n-1} \cdot 5 n\left(n^{3}+2 n^{2}-1\right)$.

Tehát:

$$
S_{4}^{*}=(-1)^{n-1} \cdot \frac{n\left(n^{3}+2 n^{2}-1\right)}{2} .
$$

Itt is megemlíthetjük, hogy az $S_{4}^{*}$ átírható $S_{4}^{*}=(-1)^{n-1} \cdot \frac{n(n+1)\left(n^{2}+n-1\right)}{2}$ alakra is.

\subsection{7. Általánosítás a binomiális tételen alapuló módszer használatával a számtani sorozat alternáló összegére}

A következőkben ötvözve a számtani sorozatnál és a váltakozó előjelü összegzésnél leírtakat, az e fejezetrészeknél alkalmazottakhoz hasonló gondolatmenettel általánosítunk, s így jutunk el a számtani sorozat alternáló összegére megadható rekurzióhoz.

Mindenekelőtt tekintsünk egy számtani sorozatot, és vizsgáljuk meg, hogy mit tudunk mondani a sorozat első $n$ tagja $p$-edik hatványának váltakozó előjelü összegéről. 
Legyen $\left\{a_{n}\right\}_{n \geq 1}$ egy számtani sorozat, amelynek az első eleme $a_{1}=a$ és differenciája $d$, ahol $a, d \in R$.

Legyen továbbá $S_{p}^{*}(a, d)=a_{1}^{p}-a_{2}^{p}+a_{3}^{p}-a_{4}^{p}+\ldots+(-1)^{n-1} \cdot a_{n}^{p}=\sum_{k=1}^{n}(-1)^{k-1} \cdot a_{k}^{p}$.

A $p=0$, illetve $d=0$ triviális esetekkel külön nem foglalkozunk, hiszen könnyen belátható, hogy

$S_{0}^{*}(a, d)=\left\{\begin{array}{ll}0, & \text { ha } n \text { páros } \\ 1, & \text { ha } n \text { páratlan, }\end{array} \quad\right.$ illetve $S_{p}^{*}(a, 0)= \begin{cases}0, & \text { ha } n \text { páros } \\ a^{p}, & \text { ha } n \text { páratlan } .\end{cases}$

Legyen tehát $d \neq 0$. Induljunk ki az

$a_{i+2}^{p+1}=a_{i}^{p+1}+\left(\begin{array}{c}p+1 \\ 1\end{array}\right) \cdot a_{i}^{p} \cdot(2 d)^{1}+\left(\begin{array}{c}p+1 \\ 2\end{array}\right) \cdot a_{i}^{p-1} \cdot(2 d)^{2}+\ldots+\left(\begin{array}{c}p+1 \\ p\end{array}\right) \cdot a_{i}^{1} \cdot(2 d)^{p}+\left(\begin{array}{c}p+1 \\ p+1\end{array}\right) \cdot(2 d)^{p+1}$

azonosságból - ahol $i, p \in N^{+}$és $a_{i+2}=a_{i}+2 d-$, melyet átrendezve kapjuk, hogy

$$
a_{i+2}^{p+1}-a_{i}^{p+1}=\left(\begin{array}{c}
p+1 \\
1
\end{array}\right) \cdot a_{i}^{p} \cdot(2 d)^{1}+\left(\begin{array}{c}
p+1 \\
2
\end{array}\right) \cdot a_{i}^{p-1} \cdot(2 d)^{2}+\ldots+\left(\begin{array}{c}
p+1 \\
p
\end{array}\right) \cdot a_{i}^{1} \cdot(2 d)^{p}+\left(\begin{array}{c}
p+1 \\
p+1
\end{array}\right) \cdot(2 d)^{p+1} .
$$

Helyettesítsük be az $i$ helyére rendre a természetes számokat 1-től $n$-ig. Így $n \mathrm{db}$ összefüggést kapunk a következőképpen:

$$
\begin{aligned}
& a_{3}^{p+1}-a_{1}^{p+1}=\left(\begin{array}{c}
p+1 \\
1
\end{array}\right) \cdot a_{1}^{p} \cdot(2 d)^{1}+\left(\begin{array}{c}
p+1 \\
2
\end{array}\right) \cdot a_{1}^{p-1} \cdot(2 d)^{2}+\ldots+\left(\begin{array}{c}
p+1 \\
p
\end{array}\right) \cdot a_{1}^{1} \cdot(2 d)^{p}+\left(\begin{array}{c}
p+1 \\
p+1
\end{array}\right) \cdot(2 d)^{p+1} \\
& a_{4}^{p+1}-a_{2}^{p+1}=\left(\begin{array}{c}
p+1 \\
1
\end{array}\right) \cdot a_{2}^{p} \cdot(2 d)^{1}+\left(\begin{array}{c}
p+1 \\
2
\end{array}\right) \cdot a_{2}^{p-1} \cdot(2 d)^{2}+\ldots+\left(\begin{array}{c}
p+1 \\
p
\end{array}\right) \cdot a_{2}^{1} \cdot(2 d)^{p}+\left(\begin{array}{c}
p+1 \\
p+1
\end{array}\right) \cdot(2 d)^{p+1} \\
& a_{5}^{p+1}-a_{3}^{p+1}=\left(\begin{array}{c}
p+1 \\
1
\end{array}\right) \cdot a_{3}^{p} \cdot(2 d)^{1}+\left(\begin{array}{c}
p+1 \\
2
\end{array}\right) \cdot a_{3}^{p-1} \cdot(2 d)^{2}+\ldots+\left(\begin{array}{c}
p+1 \\
p
\end{array}\right) \cdot a_{3}^{1} \cdot(2 d)^{p}+\left(\begin{array}{c}
p+1 \\
p+1
\end{array}\right) \cdot(2 d)^{p+1} \\
& a_{6}^{p+1}-a_{4}^{p+1}=\left(\begin{array}{c}
p+1 \\
1
\end{array}\right) \cdot a_{4}^{p} \cdot(2 d)^{1}+\left(\begin{array}{c}
p+1 \\
2
\end{array}\right) \cdot a_{4}^{p-1} \cdot(2 d)^{2}+\ldots+\left(\begin{array}{c}
p+1 \\
p
\end{array}\right) \cdot a_{4}^{1} \cdot(2 d)^{p}+\left(\begin{array}{c}
p+1 \\
p+1
\end{array}\right) \cdot(2 d)^{p+1} \\
& --\left(\begin{array}{c}
p+1 \\
2
\end{array}\right) \cdot a_{n-1}^{p-1} \cdot(2 d)^{2}+\ldots+\left(\begin{array}{c}
p+1 \\
p
\end{array}\right) \cdot a_{n-1}^{1} \cdot(2 d)^{p}+\left(\begin{array}{c}
p+1 \\
p+1
\end{array}\right) \cdot(2 d)^{p+1} \\
& a_{n+1}^{p+1}-a_{n-1}^{p+1}=\left(\begin{array}{c}
p+1 \\
1
\end{array}\right) \cdot a_{n-1}^{p} \cdot(2 d)^{1}+\left(\begin{array}{c}
p+1 \\
p
\end{array}\right) \cdot a_{n}^{1} \cdot(2 d)^{p}+\left(\begin{array}{c}
p+1 \\
p+1
\end{array}\right) \cdot(2 d)^{p+1} \\
& a_{n+2}^{p+1}-a_{n}^{p+1}=\left(\begin{array}{c}
p+1 \\
1
\end{array}\right) \cdot a_{n}^{p} \cdot(2 d)^{1}+\left(\begin{array}{c}
p+1 \\
2
\end{array}\right) \cdot(2 d)^{2}+\ldots+\left(\begin{array}{c}
p \\
p
\end{array}\right.
\end{aligned}
$$

Szorozzuk meg a felírt egyenlőségeket felváltva 1-gyel és (-1)-gyel (az elsőt 1-gyel szorozva), majd összegezzük a kapottakat. A baloldalon így egy teleszkópikus összeghez jutunk. Az összevonások után a következő eredmények lehetségesek:

Ha $n$ páros, akkor

$$
\begin{aligned}
& -a_{n+2}^{p+1}+a_{2}^{p+1}+a_{n+1}^{p+1}-a_{1}^{p+1}=\left(\begin{array}{c}
p+1 \\
1
\end{array}\right) \cdot S_{p}^{*}(a, d) \cdot(2 d)^{1}+\left(\begin{array}{c}
p+1 \\
2
\end{array}\right) \cdot S_{p-1}^{*}(a, d) \cdot(2 d)^{2}+\ldots+ \\
& +\left(\begin{array}{c}
p+1 \\
p
\end{array}\right) \cdot S_{1}^{*}(a, d) \cdot(2 d)^{p}=\left(\begin{array}{c}
p+1 \\
1
\end{array}\right) \cdot S_{p}^{*}(a, d) \cdot(2 d)+\sum_{k=2}^{p}\left(\begin{array}{c}
p+1 \\
k
\end{array}\right) \cdot S_{p+1-k}^{*}(a, d) \cdot(2 d)^{k},
\end{aligned}
$$


amelyet átrendezve - és a $\left(\begin{array}{c}p+1 \\ 1\end{array}\right)=p+1$ egyenlőséget is figyelembe véve - kapjuk, hogy

$2 d \cdot(p+1) \cdot S_{p}^{*}(a, d)=-a_{n+2}^{p+1}+a_{n+1}^{p+1}+a_{2}^{p+1}-a_{1}^{p+1}-\sum_{k=2}^{p}\left(\begin{array}{c}p+1 \\ k\end{array}\right) \cdot S_{p+1-k}^{*}(a, d) \cdot(2 d)^{k}$.

Ha $n$ páratlan, akkor

$$
\begin{aligned}
& a_{n+2}^{p+1}-a_{1}^{p+1}-a_{n+1}^{p+1}+a_{2}^{p+1}=\left(\begin{array}{c}
p+1 \\
1
\end{array}\right) \cdot S_{p}^{*}(a, d) \cdot(2 d)^{1}+\left(\begin{array}{c}
p+1 \\
2
\end{array}\right) \cdot S_{p-1}^{*}(a, d) \cdot(2 d)^{2}+\ldots+ \\
& +\left(\begin{array}{c}
p+1 \\
p
\end{array}\right) \cdot S_{1}^{*}(a, d) \cdot(2 d)^{p}+(2 d)^{p+1}=(2 d)^{p+1}+2 d \cdot\left(\begin{array}{c}
p+1 \\
1
\end{array}\right) \cdot S_{p}^{*}(a, d)+\sum_{k=2}^{p}\left(\begin{array}{c}
p+1 \\
k
\end{array}\right) \cdot S_{p+1-k}^{*}(a, d) \cdot(2 d)^{k},
\end{aligned}
$$

amelyet átrendezve - és itt is figyelembe véve a $\left(\begin{array}{c}p+1 \\ 1\end{array}\right)=p+1$ egyenlöséget - adódik, hogy $2 d \cdot(p+1) \cdot S_{p}^{*}(a, d)=a_{n+2}^{p+1}-a_{n+1}^{p+1}+a_{2}^{p+1}-a_{1}^{p+1}-(2 d)^{p+1}-\sum_{k=2}^{p}\left(\begin{array}{c}p+1 \\ k\end{array}\right) \cdot S_{p+1-k}^{*}(a, d) \cdot(2 d)^{k}$.

Összegezve:

$$
\begin{aligned}
& 2 d \cdot(p+1) \cdot S_{p}^{*}(a, d)=(-1)^{n-1} \cdot\left\lfloor a_{n+2}^{p+1}-a_{n+1}^{p+1}-d \cdot(2 d)^{p}\right\rfloor+ \\
& +a_{2}^{p+1}-a_{1}^{p+1}-d \cdot(2 d)^{p}-\sum_{k=2}^{p}\left(\begin{array}{c}
p+1 \\
k
\end{array}\right) \cdot S_{p+1-k}^{*}(a, d) \cdot(2 d)^{k},
\end{aligned}
$$

ahonnan

$S_{p}^{*}(a, d)=\frac{(-1)^{n-1} \cdot\left[a_{n+2}^{p+1}-a_{n+1}^{p+1}-d \cdot(2 d)^{p}\right]+a_{2}^{p+1}-a_{1}^{p+1}-d \cdot(2 d)^{p}-\sum_{k=2}^{p}\left(\begin{array}{c}p+1 \\ k\end{array}\right) \cdot S_{p+1-k}^{*}(a, d) \cdot(2 d)^{k}}{2 d \cdot(p+1)}$.

A kapott formuláról látható, hogy ezúttal is egy rekurziós összefüggést kaptunk, azaz $S_{p}^{*}(a, d)$ kiszámítása az $S_{1}^{*}(a, d), S_{2}^{*}(a, d), \ldots, S_{p-1}^{*}(a, d)$ összegekre vonatkozó eredmények felhasználásával lehetséges.

\subsubsection{Speciális esetek a számtani sorozat alternáló összege esetén kapott összefüggésre}

A továbbiakban a számtani sorozat alternáló összegével kapcsolatban lássunk néhány érdekes konkrét esetet.

Ha $p=1$, akkor

$$
\begin{aligned}
& 2 d \cdot 2 \cdot S_{1}^{*}(a, d)=(-1)^{n-1} \cdot\left\lfloor a_{n+2}^{2}-a_{n+1}^{2}-d \cdot(2 d)^{1}\right\rfloor+a_{2}^{2}-a_{1}^{2}-d \cdot(2 d)^{1}= \\
& =(-1)^{n-1} \cdot\left\{[a+(n+1) d]^{2}-(a+n d)^{2}-2 d^{2}\right\}+(a+d)^{2}-a^{2}-2 d^{2} .
\end{aligned}
$$

A müveletek elvégzése és az összevonások után kapjuk, hogy

$$
4 d \cdot S_{1}^{*}(a, d)=(-1)^{n-1} \cdot\left(2 a d+2 n d^{2}-d^{2}\right)+2 a d-d^{2}=d \cdot\left[(-1)^{n-1} \cdot(2 a+2 n d-d)+2 a-d\right],
$$


ahonnan

$$
S_{1}^{*}(a, d)=\frac{(-1)^{n-1} \cdot(2 n d+2 a-d)+2 a-d}{4} .
$$

A kapott változat néhány speciális esete:

$$
\begin{array}{ll}
a=1, d=1 \text { esetén: } & S_{1}^{*}(1,1)=S_{1}^{*}=\frac{(-1)^{n-1} \cdot(2 n+1)+1}{4} . \\
a=1, d=2 \text { esetén: } & S_{1}^{*}(1,2)=\frac{(-1)^{n-1} \cdot 4 n}{4}=(-1)^{n-1} \cdot n . \\
a=1, d=3 \text { esetén: } & S_{1}^{*}(1,3)=\frac{(-1)^{n-1} \cdot(6 n-1)-1}{4} . \\
a=2, d=3 \text { esetén: } & S_{1}^{*}(2,3)=\frac{(-1)^{n-1} \cdot(6 n+1)+1}{4} .
\end{array}
$$

Ha $p=2$, akkor

$2 d \cdot 3 \cdot S_{2}^{*}(a, d)=(-1)^{n-1} \cdot\left[a_{n+2}^{3}-a_{n+1}^{3}-d \cdot(2 d)^{2}\right\rfloor+a_{2}^{3}-a_{1}^{3}-d \cdot(2 d)^{2}-$

$-\left(\begin{array}{l}3 \\ 2\end{array}\right) \cdot S_{1}^{*}(a, d) \cdot(2 d)^{2}=(-1)^{n-1} \cdot\left\{[a+(n+1) d]^{3}-(a+n d)^{3}-4 d^{3}\right\}+(a+d)^{3}-a^{3}-4 d^{3}-$

$-12 d^{2} \cdot \frac{(-1)^{n-1} \cdot(2 n d+2 a-d)+2 a-d}{4}$.

A zárójelek felbontása és az összevonások után

$$
\begin{aligned}
& 6 d \cdot S_{2}^{*}(a, d)=(-1)^{n-1} \cdot\left(3 a^{2} d+6 a n d^{2}+3 a d^{2}+3 n^{2} d^{3}+3 n d^{3}-3 d^{3}\right)+ \\
& +3 a^{2} d+3 a d^{2}-3 d^{3}-(-1)^{n-1} \cdot\left(6 a d^{2}+6 n d^{3}-3 d^{3}\right)-6 a d^{2}+3 d^{3}= \\
& =3 d \cdot\left[(-1)^{n-1} \cdot\left(n^{2} d^{2}+2 a n d-n d^{2}+a^{2}-a d\right)+a^{2}-a d\right],
\end{aligned}
$$

ahonnan figyelembe véve, hogy $d \neq 0$ kapjuk, hogy

$$
S_{2}^{*}(a, d)=\frac{(-1)^{n-1} \cdot\left(n^{2} d^{2}+2 a n d-n d^{2}+a^{2}-a d\right)+a^{2}-a d}{2},
$$

illetve az $n$ hatványai szerint rendezve

$$
S_{2}^{*}(a, d)=\frac{(-1)^{n-1} \cdot\left[n^{2} d^{2}+n d(2 a-d)+a^{2}-a d\right]+a^{2}-a d}{2} .
$$

Az itteni felírásnak négy speciális esete az alábbi:

$$
\begin{array}{ll}
a=1, d=1 \text { esetén: } & S_{2}^{*}(1,1)=S_{2}^{*}=\frac{(-1)^{n-1} \cdot\left(n^{2}+n\right)}{2}=(-1)^{n-1} \cdot \frac{n(n+1)}{2} . \\
a=1, d=2 \text { esetén: } & S_{2}^{*}(1,2)=\frac{(-1)^{n-1} \cdot\left(4 n^{2}-1\right)-1}{2}=\frac{(-1)^{n-1} \cdot(2 n-1)(2 n+1)-1}{2} . \\
a=1, d=3 \text { esetén: } & S_{2}^{*}(1,3)=\frac{(-1)^{n-1} \cdot\left(9 n^{2}-3 n-2\right)-2}{2}=\frac{(-1)^{n-1} \cdot(3 n-2)(3 n+1)}{2}-1 .
\end{array}
$$




$$
a=2, d=3 \text { esetén: } S_{2}^{*}(2,3)=\frac{(-1)^{n-1} \cdot\left(9 n^{2}+3 n-2\right)-2}{2}=\frac{(-1)^{n-1} \cdot(3 n+2)(3 n-1)}{2}-1 .
$$

Ha $p=3$, akkor

$$
\begin{aligned}
& 2 d \cdot 4 \cdot S_{3}^{*}(a, d)=(-1)^{n-1} \cdot\left[a_{n+2}^{4}-a_{n+1}^{4}-d \cdot(2 d)^{3}\right]+a_{2}^{4}-a_{1}^{4}-d \cdot(2 d)^{3}- \\
& -\left(\begin{array}{l}
4 \\
2
\end{array}\right) \cdot S_{2}^{*}(a, d) \cdot(2 d)^{2}-\left(\begin{array}{l}
4 \\
3
\end{array}\right) \cdot S_{1}^{*}(a, d) \cdot(2 d)^{3}=(-1)^{n-1} \cdot\left\{[a+(n+1) d]^{4}-(a+n d)^{4}-8 d^{4}\right\}+ \\
& +(a+d)^{3}-a^{3}-8 d^{4}-24 d^{2} \cdot \frac{(-1)^{n-1} \cdot\left(n^{2} d^{2}+2 a n d-n d^{2}+a^{2}-a d\right)+a^{2}-a d}{2}- \\
& -32 d^{3} \cdot \frac{(-1)^{n-1} \cdot(2 n d+2 a-d)+2 a-d}{4} .
\end{aligned}
$$

A lehetséges egyszerüsítések elvégzése és a zárójelek felbontása után $8 d \cdot S_{3}^{*}(a, d)=$ $=(-1)^{n-1} \cdot\left(4 a^{3} d+12 a^{2} n d^{2}+6 a^{2} d^{2}+12 a n^{2} d^{3}+12 a n d^{3}+4 a d^{3}+4 n^{3} d^{4}+6 n^{2} d^{4}+4 n d^{4}-7 d^{4}\right)+$ $+4 a^{3} d+6 a^{2} d^{2}+4 a d^{3}-7 d^{4}-(-1)^{n-1} \cdot\left(12 n^{2} d^{4}+24 n a d^{3}-12 n d^{4}+12 a^{2} d^{2}-12 a d^{3}\right)-$ $-12 a^{2} d^{2}+12 a d^{3}-(-1)^{n-1} \cdot\left(16 n d^{4}+16 a d^{3}-8 d^{4}\right)-16 a d^{3}+8 d^{4}=$ $=d \cdot\left[(-1)^{n-1} \cdot\left(4 n^{3} d^{3}+12 a n^{2} d^{2}-6 n^{2} d^{3}+12 a^{2} n d-12 a n d^{2}+4 a^{3}-6 a^{2} d+d^{3}\right)+4 a^{3}-6 a^{2} d+d^{3}\right]$, ahonnan

$$
\begin{aligned}
& S_{3}^{*}(a, d)=(-1)^{n-1} \cdot \frac{4 n^{3} d^{3}+12 a n^{2} d^{2}-6 n^{2} d^{3}+12 a^{2} n d-12 a n d^{2}+4 a^{3}-6 a^{2} d+d^{3}}{8}+ \\
& +\frac{4 a^{3}-6 a^{2} d+d^{3}}{8}
\end{aligned}
$$

vagy az $n$ hatványai szerint rendezve

$$
S_{3}^{*}(a, d)=\frac{(-1)^{n-1} \cdot\left[4 n^{3} d^{3}+6 n^{2} d^{2}(2 a-d)+12 a n d(a-d)+4 a^{3}-6 a^{2} d+d^{3}\right]+4 a^{3}-6 a^{2} d+d^{3}}{8} \text {. }
$$

A fenti összefüggés négy konkrét alesete:

$$
\begin{array}{ll}
a=1, d=1 \text { esetén: } & S_{3}^{*}(1,1)=S_{3}^{*}=\frac{(-1)^{n-1} \cdot\left(4 n^{3}+6 n^{2}-1\right)-1}{8} . \\
a=1, d=2 \text { esetén: } & S_{3}^{*}(1,2)=\frac{(-1)^{n-1} \cdot\left(32 n^{3}-24 n\right)}{8}=(-1)^{n-1} \cdot n\left(4 n^{2}-3\right) . \\
a=1, d=3 \text { esetén: } & S_{3}^{*}(1,3)=\frac{(-1)^{n-1} \cdot\left(108 n^{3}-54 n^{2}-72 n+13\right)+13}{8} . \\
a=2, d=3 \text { esetén: } & S_{3}^{*}(2,3)=\frac{(-1)^{n-1} \cdot\left(108 n^{3}+54 n^{2}-72 n-13\right)-13}{8} .
\end{array}
$$

\section{Megjegyzés}

Megemlítjük, hogy a tizennyolcadik hatványig bezárólag az $S_{p}^{*}(1,2)$ speciális eset eredményei megtalálhatóak a [48]-ban. 
Az e fejezetben tárgyaltak rövid összegzése az alábbi: az $S_{p}$ hatványösszegek kiszámítására vonatkozó rekurziót a binomiális tétel segítségével állítottuk elő, bemutatva a képlet néhány speciális esetét. A módszer alkalmazásával rekurziós formulát vezettünk le a számtani sorozatok első $n$ tagjának azonos kitevőjü hatványösszegeire, továbbá felírtuk 27 konkrét esetben a kapott eredményeket. A bemutatott módszer segítségével rekurziós összefüggést írtunk fel az első $n$ pozitív egész szám $p$-edik hatványa váltakozó előjelű összegének kiszámításához, majd a fejezet végén a számtani sorozatra bemutatott általánosítást elvégeztük a számtani sorozat alternáló hatványösszegeire is, közreadva 12 konkrét eset formuláit. Mindezekből a legfontosabb leszürhető tanulság, hogy mind a rekurzió általános képletei, mind pedig a speciális esetek szemléletesen igazolják azt, hogy a binomiális tételen alapuló rekurziós eljárás széleskörüen és hatékonyan alkalmazható. A módszer kitünő lehetőséget biztosít bizonyos összegzési feladatok viszonylag egyszerü és gyors megoldására, illetve ezek kapcsán érdekes összefüggések feltárására.

\subsection{Rekurziós összefüggés levezetése a szimmetria felhasználásával}

A hatványösszeg kiszámítására alkalmas rekurzió felírására vezető negyedik módszer nem igényel különösebb ismereteket a kombinatorika területéről, de a rekurziók és a teleszkópikus összegek elméletéből igen.

Ennél a problémamegközelítésnél a gondolatmenet a következö: először egy adott sorozat tagjai között állapítunk meg rekurziós kapcsolatot, majd a kapott eredményt felhasználva a sorozat tagjait összegezzük. Így egy teleszkópikus összeghez jutunk. A teleszkópikus összeg eredményével és az $1,2, \ldots,(p-1)$ számokhoz rendelt szimmetrikus összegek segítségével végül rekurziós összefüggést állapítunk meg az $S_{1}, S_{2}, \ldots, S_{p-1}$ között.

\subsubsection{A rekurziós összefüggés előállítása}

Mielőtt magával a problémával foglalkoznánk elöször egy definíciót, majd egy tételt ismertetünk: ezek szükséges „kellékek” mind a rekurziós probléma megoldásához, mind pedig a később bevezetésre kerülő ún. Stirling- és Bell-számok tárgyalásához.

Vezessük be a következő fogalmakat és jelöléseket:

\section{$\underline{1 . \text { Definíció }}$}

Ha $i$ és $k$ természetes számok, akkor legyen

$$
[i]^{k}=i(i+1)(i+2) \ldots(i+k-1) \text { és }[i]_{k}=i(i-1)(i-2) \ldots(i-k+1)
$$

úgy, hogy definíció szerint $[i]^{0}=[i]_{0}=1$.

$\mathrm{Az}[i]^{k}$ szorzatot emelkedő faktoriálisnak, míg $[i]_{k}$-t süllyedő faktoriálisnak nevezzük.

Az értelmezés alapján belátható, hogy $\left(\begin{array}{l}i \\ k\end{array}\right)=\frac{[i]_{k}}{k !}$.

Mielött rátérnénk a rekurziós összefüggés levezetésére, lássunk egy fontos tulajdonságot az emelkedő és süllyedő faktoriálissal kapcsolatban. 


\section{Tétel}

Teljesülnek a következő egyenlöségek:
a) $[x+y]_{n}=\sum_{k=0}^{n}\left(\begin{array}{l}n \\ k\end{array}\right) \cdot[x]_{k} \cdot[y]_{n-k}$.
b) $[x+y]^{n}=\sum_{k=0}^{n}\left(\begin{array}{l}n \\ k\end{array}\right) \cdot[x]^{n} \cdot[y]^{n-k}$.

Bizonyítás:

Az állítás igazolása mindkét esetben a teljes indukció módszerével történik $n$ szerint.

a) Ha $n=1$, akkor

$$
[x+y]_{1}=x+y=1 \cdot y+x \cdot 1=[x]_{0} \cdot[y]_{1}+[x]_{1} \cdot[y]_{0}=\sum_{k=0}^{1}\left(\begin{array}{l}
1 \\
k
\end{array}\right) \cdot[x]_{k} \cdot[y]_{1-k},
$$

tehát az egyenlőség igaz.

Tegyük fel, hogy az a) összefüggés teljesül minden $1 \leq n \leq m-1$ esetben, ahol $m \geq 2$.

Ekkor

$$
\begin{aligned}
& {[x+y]_{m}=[x+y]_{m-1} \cdot(x+y-m+1)=\sum_{k=0}^{m-1}\left(\begin{array}{c}
m-1 \\
k
\end{array}\right) \cdot[x]_{k} \cdot[y]_{m-1-k} \cdot(x+y-m+1)=} \\
& =\sum_{k=0}^{m-1}\left(\begin{array}{c}
m-1 \\
k
\end{array}\right) \cdot[x]_{k} \cdot[y]_{m-1-k} \cdot(x-k+y-m+k+1)= \\
& =\sum_{k=0}^{m-1}\left(\begin{array}{c}
m-1 \\
k
\end{array}\right) \cdot[x]_{k} \cdot[y]_{m-1-k} \cdot(x-k)+\sum_{k=0}^{m-1}\left(\begin{array}{c}
m-1 \\
k
\end{array}\right) \cdot[x]_{k} \cdot[y]_{m-1-k} \cdot(y-m+k+1)= \\
& =\sum_{k=0}^{m-1}\left(\begin{array}{c}
m-1 \\
k
\end{array}\right) \cdot[x]_{k+1} \cdot[y]_{m-1-k}+\sum_{k=0}^{m-1}\left(\begin{array}{c}
m-1 \\
k
\end{array}\right) \cdot[x]_{k} \cdot[y]_{m-k}= \\
& =\left(\begin{array}{c}
m-1 \\
m-1
\end{array}\right) \cdot[x]_{m} \cdot[y]_{0}+\sum_{k=1}^{m-1}\left[\left(\begin{array}{c}
m-1 \\
k-1
\end{array}\right)+\left(\begin{array}{c}
m-1 \\
k
\end{array}\right)\right] \cdot[x]_{k} \cdot[y]_{m-k}+\left(\begin{array}{c}
m-1 \\
0
\end{array}\right) \cdot[x]_{0} \cdot[y]_{m}= \\
& =\left(\begin{array}{c}
m \\
m
\end{array}\right) \cdot[x]_{m} \cdot[y]_{0}+\sum_{k=1}^{m-1}\left(\begin{array}{c}
m \\
k
\end{array}\right) \cdot[x]_{k} \cdot[y]_{m-k}+\left(\begin{array}{c}
m \\
0
\end{array}\right) \cdot[x]_{0} \cdot[y]_{m}=\sum_{k=0}^{m}\left(\begin{array}{c}
m \\
k
\end{array}\right) \cdot[x]_{k} \cdot[y]_{m-k} \cdot
\end{aligned}
$$

b) Ha $n=1$, akkor

$$
[x+y]^{1}=x+y=1 \cdot y+x \cdot 1=[x]^{0} \cdot[y]^{1}+[x]^{1} \cdot[y]^{0}=\sum_{k=0}^{1}\left(\begin{array}{l}
1 \\
k
\end{array}\right) \cdot[x]^{k} \cdot[y]^{1-k},
$$

tehát az egyenlőség igaz.

Tegyük fel, hogy a b) összefüggés teljesül minden $1 \leq n \leq m-1$ esetben, ahol $m \geq 2$.

Ekkor

$$
\begin{aligned}
& {[x+y]^{m}=[x+y]^{m-1} \cdot(x+y+m-1)=\sum_{k=0}^{m-1}\left(\begin{array}{c}
m-1 \\
k
\end{array}\right) \cdot[x]^{k} \cdot[y]^{m-1-k} \cdot(x+y+m-1)=} \\
& =\sum_{k=0}^{m-1}\left(\begin{array}{c}
m-1 \\
k
\end{array}\right) \cdot[x]^{k} \cdot[y]^{m-1-k} \cdot(x+k+y+m-k-1)= \\
& =\sum_{k=0}^{m-1}\left(\begin{array}{c}
m-1 \\
k
\end{array}\right) \cdot[x]^{k} \cdot[y]^{m-1-k} \cdot(x+k)+\sum_{k=0}^{m-1}\left(\begin{array}{c}
m-1 \\
k
\end{array}\right) \cdot[x]^{k} \cdot[y]^{m-1-k} \cdot(y+m-k-1)=
\end{aligned}
$$




$$
\begin{aligned}
& =\sum_{k=0}^{m-1}\left(\begin{array}{c}
m-1 \\
k
\end{array}\right) \cdot[x]^{k+1} \cdot[y]^{m-1-k}+\sum_{k=0}^{m-1}\left(\begin{array}{c}
m-1 \\
k
\end{array}\right) \cdot[x]^{k} \cdot[y]^{m-k}= \\
& =\left(\begin{array}{c}
m-1 \\
m-1
\end{array}\right) \cdot[x]^{m} \cdot[y]^{0}+\sum_{k=1}^{m-1}\left[\left(\begin{array}{c}
m-1 \\
k-1
\end{array}\right)+\left(\begin{array}{c}
m-1 \\
k
\end{array}\right)\right] \cdot[x]^{k} \cdot[y]^{m-k}+\left(\begin{array}{c}
m-1 \\
0
\end{array}\right) \cdot[x]^{0} \cdot[y]^{m}= \\
& =\left(\begin{array}{c}
m \\
m
\end{array}\right) \cdot[x]^{m} \cdot[y]^{0}+\sum_{k=1}^{m-1}\left(\begin{array}{c}
m \\
k
\end{array}\right) \cdot[x]^{k} \cdot[y]^{m-k}+\left(\begin{array}{c}
m \\
0
\end{array}\right) \cdot[x]^{0} \cdot[y]^{m}=\sum_{k=0}^{m}\left(\begin{array}{c}
m \\
k
\end{array}\right) \cdot[x]^{k} \cdot[y]^{m-k} .
\end{aligned}
$$

Q.e.d.

Ezek után térjünk rá a rekurziós összefüggés levezetésére!

Legyen az $A_{k}=\sum_{i=1}^{n}[i]^{k+1}$, ahol $k=0 ; 1 ; 2 ; \ldots$ és $i=1 ; 2 ; \ldots$.

Ha az $i=0$, akkor nyilvánvaló, hogy $[0]^{k+1}=0$.

$\mathrm{Az} A_{k}$ könnyebb kiszámítása érdekében vegyük észre az $[i]^{k+1}$ megfelelő tagjai között az alábbi rekurziót:

$$
\begin{aligned}
& {[i]^{k+1}=i(i+1)(i+2) \ldots(i+k)=\frac{1}{k+2} \cdot i(i+1)(i+2) \ldots(i+k)(k+2)=} \\
& =\frac{1}{k+2} \cdot i(i+1)(i+2) \ldots(i+k)[(i+k+1)-(i-1)]= \\
& =\frac{1}{k+2} \cdot[i(i+1)(i+2) \ldots(i+k)(i+k+1)-(i-1) i(i+1)(i+2) \ldots(i+k)]= \\
& =\frac{1}{k+2} \cdot\left([i]^{k+2}-[i-1]^{k+2}\right) .
\end{aligned}
$$

Tehát:

$$
[i]^{k+1}=\frac{1}{k+2} \cdot\left([i]^{k+2}-[i-1]^{k+2}\right) .
$$

Ezek alapján felírható, hogy $A_{k}=\sum_{i=1}^{n}[i]^{k+1}=\frac{1}{k+2} \cdot \sum_{i=1}^{n}\left([i]^{k+2}-[i-1]^{k+2}\right)$.

A $\sum_{i=1}^{n}\left([i]^{k+2}-[i-1]^{k+2}\right)$ egy teleszkópikus összeg, amely az összevonások után $[n]^{k+2}-[0]^{k+2}$ lesz, és így

$$
A_{k}=\frac{1}{k+2} \cdot\left([n]^{k+2}-[0]^{k+2}\right)=\frac{1}{k+2} \cdot\left([n]^{k+2}-0\right)=\frac{[n]^{k+2}}{k+2}=\frac{n(n+1)(n+2) \ldots(n+k+1)}{k+2},
$$

azaz

$$
A_{k}=\sum_{i=1}^{n}[i]^{k+1}=\sum_{i=1}^{n}[i(i+1)(i+2) \ldots(i+k)]=\frac{n(n+1)(n+2) \ldots(n+k+1)}{k+2},
$$

ahol $k=0 ; 1 ; 2 ; \ldots$.

Ha $k=0$, akkor $A_{0}=\sum_{i=1}^{n}[i]^{1}=\sum_{i=1}^{n} i=S_{1}$, de $A_{0}=\frac{n(n+1)}{2}$, ezért $S_{1}=\frac{n(n+1)}{2}$. 


\section{Megjegyzés}

A $k=1$ eset két szemléletes bizonyítása:

- elöször a $\sum_{i=1}^{n-1}[i]^{2}$ esetre (3.4.1. ábra),

(i)

$$
\gtrless_{11}^{2}=\frac{111^{2}}{3}
$$

(ii)

$$
\frac{n-1 \quad n+1}{3}+\sum_{1}^{n-1}=\frac{111}{3} n+1
$$

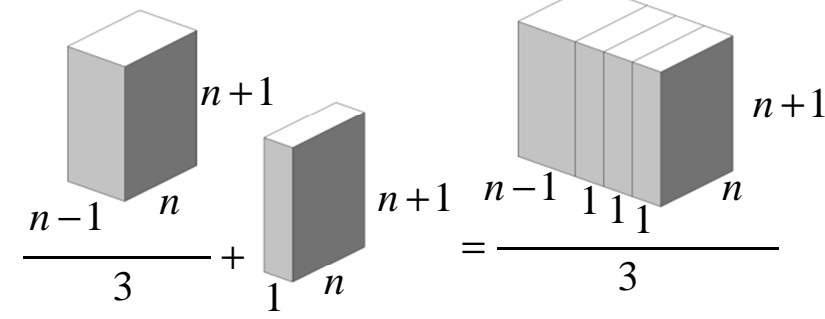

\subsection{1. ábra}

- $\quad$ majd a $\sum_{i=1}^{n}[i]^{2}$ esetre (3.4.2. ábra).

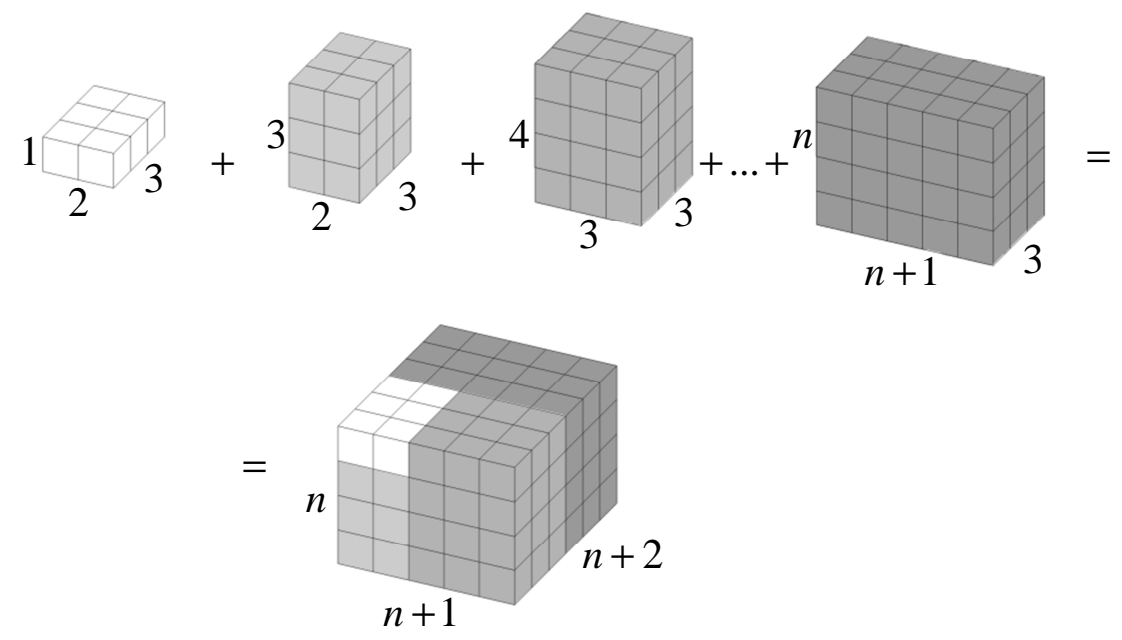

$3 \cdot \sum_{i=1}^{n}[i]^{2}=3 \cdot[1 \cdot 2+2 \cdot 3+3 \cdot 4+\ldots+n(n+1)]=n(n+1)(n+2)$

\subsection{2. ábra}


Legyen $p \geq 2$ egész és jelölje $s_{1}, s_{2}, \ldots, s_{p-1}$ az $1,2, \ldots,(p-1)$ számokhoz rendelt alábbi ún. szimmetrikus összegeket:

$$
\left\{\begin{array}{l}
s_{1}=1+2+3+\ldots+(p-1) \\
s_{2}=1 \cdot 2+1 \cdot 3+\ldots+(p-2) \cdot(p-1) \\
------------------- \\
s_{p-1}=1 \cdot 2 \cdot 3 \cdot \ldots \cdot(p-1)
\end{array}\right.
$$

Ekkor

$$
\begin{aligned}
& A_{p-1}=\sum_{i=1}^{n}[i]^{p}=\sum_{i=1}^{n}[i(i+1)(i+2) \ldots(i+p-1)]= \\
& =\sum_{i=1}^{n}\left(i^{p}+s_{1} \cdot i^{p-1}+s_{2} \cdot i^{p-2}+\ldots+s_{p-2} \cdot i^{2}+s_{p-1} \cdot i\right)= \\
& =\sum_{i=1}^{n} i^{p}+s_{1} \cdot \sum_{i=1}^{n} i^{p-1}+s_{2} \cdot \sum_{i=1}^{n} i^{p-2}+\ldots+s_{p-2} \cdot \sum_{i=1}^{n} i^{2}+s_{p-1} \cdot \sum_{i=1}^{n} i= \\
& =S_{p}+s_{1} \cdot S_{p-1}+s_{2} \cdot S_{p-2}+\ldots+s_{p-2} \cdot S_{2}+s_{p-1} \cdot S_{1} .
\end{aligned}
$$

Innen

$$
S_{p}=A_{p-1}-s_{1} \cdot S_{p-1}-s_{2} \cdot S_{p-2}-\ldots-s_{p-2} \cdot S_{2}-s_{p-1} \cdot S_{1}=A_{p-1}-\sum_{i=1}^{p-1} s_{i} \cdot S_{p-i}
$$

vagyis

$$
S_{p}=A_{p-1}-\sum_{i=1}^{p-1} s_{i} \cdot S_{p-i}=\frac{[n]^{p+1}}{p+1}-\sum_{i=1}^{p-1} s_{i} \cdot S_{p-i}=\frac{n(n+1)(n+2) \ldots(n+p)}{p+1}-\sum_{i=1}^{p-1} s_{i} \cdot S_{p-i} .
$$

Összefoglalva a rekurziós összefüggés az alábbiakban áll elő:

$$
S_{p}=\frac{[n]^{p+1}}{p+1}-\sum_{i=1}^{p-1} s_{i} \cdot S_{p-i}=\frac{n(n+1)(n+2) \ldots(n+p)}{p+1}-\sum_{i=1}^{p-1} s_{i} \cdot S_{p-i},
$$

ahol az $s_{1}, s_{2}, \ldots, s_{p-1}$ szimmetrikus összegek a (3.4.5) összefüggések szerintiek.

Belátható, hogy az $S_{p}$ kiszámítása az $A_{p-1}$, illetve az $S_{1}, S_{2}, \ldots, S_{p-1}$ eredményeinek felhasználásával történik.

\section{Megjegyzés}

Felhasználva, hogy az $S_{1}=\frac{n(n+1)}{2}$, azaz $2 \cdot S_{1}=n(n+1)$, a (3.4.6) egyenlőség átírható az alábbi alakra:

$$
S_{p}=\frac{2 \cdot S_{1} \cdot(n+2)(n+3) \ldots(n+p)}{p+1}-\sum_{i=1}^{p-1} s_{i} \cdot S_{p-i} .
$$

Bebizonyítható (például a teljes indukció módszerét felhasználva), hogy

a) az $S_{1} \mid S_{p}$ minden $p$ pozitív természetes szám esetén (a 3.2.2. fejezet 7. megjegyzésében már felírtunk egy másik összefüggést ezen oszthatóság bizonyítására); 
b) az $S_{p}$ egy $(p+1)$-edfokú polinom $n$-ben, amelynek főegyütthatója $\frac{1}{p+1}$, a $p$-edfokú tag együtthatója $\frac{1}{2}$ és a konstans tag 0.

Ugyancsak teljes indukcióval bebizonyítható, hogy ha $p \in N^{+}$és $p$ páros szám, akkor $S_{p}=n(n+1)(2 n+1) \cdot Q(n)$

alakú, ahol $Q(n)$ egy $(p-2)$-edfokú polinom $n$-ben.

\subsubsection{A kapott összefüggés néhány speciális esete}

Az alábbiakban felhasználva az $S_{1}$ és $S_{2}$ összegeket, megállapítjuk az $S_{3}, S_{4}$ és $S_{5}$ összegekre érvényes formulákat.

Ha $p=3$, akkor

$$
\left\{\begin{array}{l}
s_{1}=1+2=3 \\
s_{2}=1 \cdot 2=2
\end{array}\right.
$$

Felhasználva a (3.4.6) alatti összefüggést és az $S_{1}, S_{2}$ eredményeit, kapjuk hogy

$$
\begin{aligned}
& S_{3}=A_{2}-3 \cdot S_{2}-2 \cdot S_{1}=\frac{n(n+1)(n+2)(n+3)}{4}-3 \cdot \frac{n(n+1)(2 n+1)}{6}-2 \cdot \frac{n(n+1)}{2}= \\
& =\frac{n(n+1)}{4} \cdot[(n+2)(n+3)-2(2 n+1)-4]=\frac{n(n+1)}{4} \cdot\left(n^{2}+5 n+6-4 n-2-4\right)= \\
& =\frac{n(n+1)}{4} \cdot\left(n^{2}+n\right)=\frac{n^{2}(n+1)^{2}}{4} .
\end{aligned}
$$

Tehát az első $n$ pozitív egész szám köbeinek összege:

$$
S_{3}=1^{3}+2^{3}+3^{3}+\ldots+n^{3}=\frac{n^{2}(n+1)^{2}}{4} .
$$

Ha $p=4$, akkor

$$
\left\{\begin{array}{l}
s_{1}=1+2+3=6 \\
s_{2}=1 \cdot 2+1 \cdot 3+2 \cdot 3=11 \\
s_{3}=1 \cdot 2 \cdot 3=6
\end{array}\right.
$$

Ismét csak felhasználva a (3.4.6) összefüggést és az $S_{1}, S_{2}, S_{3}$ eredményeit, kapjuk hogy

$$
\begin{aligned}
& S_{4}=A_{3}-6 \cdot S_{3}-11 \cdot S_{2}-6 \cdot S_{1}=\frac{n(n+1)(n+2)(n+3)(n+4)}{5}-6 \cdot \frac{n^{2}(n+1)^{2}}{4}-11 \cdot \frac{n(n+1)(2 n+1)}{6}- \\
& -6 \cdot \frac{n(n+1)}{2}=\frac{n(n+1)}{30} \cdot[6(n+2)(n+3)(n+4)-45 n(n+1)-55(2 n+1)-90]=
\end{aligned}
$$




$$
\begin{aligned}
& =\frac{n(n+1)}{30} \cdot\left(6 n^{3}+54 n^{2}+156 n+144-45 n^{2}-45 n-110 n-55-90\right)= \\
& =\frac{n(n+1)}{30} \cdot\left(6 n^{3}+9 n^{2}+n-1\right)=\frac{n(n+1)}{30} \cdot(2 n+1)\left(3 n^{2}+3 n-1\right) .
\end{aligned}
$$

Tehát adódik, hogy:

$$
S_{4}=1^{4}+2^{4}+3^{4}+\ldots+n^{4}=\frac{n(n+1)(2 n+1)\left(3 n^{2}+3 n-1\right)}{30} .
$$

Ha $p=5$, akkor

$$
\left\{\begin{array}{l}
s_{1}=1+2+3+4=10 \\
s_{2}=1 \cdot 2+1 \cdot 3+1 \cdot 4+2 \cdot 3+2 \cdot 4+3 \cdot 4=35 \\
s_{3}=1 \cdot 2 \cdot 3+1 \cdot 2 \cdot 4+1 \cdot 3 \cdot 4+2 \cdot 3 \cdot 4=50 \\
s_{4}=1 \cdot 2 \cdot 3 \cdot 4=24
\end{array}\right.
$$

A kapott értékeket behelyettesítve a (3.4.6) összefüggésbe és az $S_{1}, S_{2}, S_{3}, S_{4}$ eredményeit felhasználva

$$
\begin{aligned}
& S_{5}=A_{4}-10 \cdot S_{4}-35 \cdot S_{3}-50 \cdot S_{2}-24 \cdot S_{1}=\frac{n(n+1)(n+2)(n+3)(n+4)(n+5)}{6}- \\
& -10 \cdot \frac{n(n+1)(2 n+1)\left(3 n^{2}+3 n-1\right)}{30}-35 \cdot \frac{n^{2}(n+1)^{2}}{4}-50 \cdot \frac{n(n+1)(2 n+1)}{6}-24 \cdot \frac{n(n+1)}{2}= \\
& =\frac{n(n+1)}{12} \cdot\left[2(n+2)(n+3)(n+4)(n+5)-4(2 n+1)\left(3 n^{2}+3 n-1\right)-105 n(n+1)-100(2 n+1)-144\right] .
\end{aligned}
$$

A müveletek elvégzése és az összevonások után, kapjuk hogy

$$
\begin{aligned}
& S_{5}=\frac{n(n+1)}{12} \cdot\left(2 n^{4}+4 n^{3}+n^{2}-n\right)=\frac{n^{2}(n+1)}{12} \cdot\left(2 n^{3}+4 n^{2}+n-1\right)= \\
& =\frac{n^{2}(n+1)}{12} \cdot(n+1)\left(2 n^{2}+2 n-1\right) .
\end{aligned}
$$

Tehát:

$$
S_{5}=1^{5}+2^{5}+3^{5}+\ldots+n^{5}=\frac{n^{2}(n+1)^{2}\left(2 n^{2}+2 n-1\right)}{12} .
$$

Ez a módszer - mely mint látható, a középiskolai tananyagon túlnyúló ismereteket is igényel - egy kissé hosszabb levezetést vár el, de szintén szépen előállítja a kívánt rekurziót.

\subsubsection{A Bell- és Stirling-számok megjelenése}

Az emelkedő és a süllyedő faktoriálisok nemcsak az első $n$ pozitív egész szám azonos hatványainak kiszámításához szükséges rekurzióban jelenhetnek meg. Fontos szerepet játszanak például abban, hogy hogyan lehet egy $k$ hatványai szerint felírt polinomot átalakítani binomiális együtthatókkal felírt polinommá. Az ebben a transzformációban szereplö együtthatókat nevezik Stirling-számoknak. 
Az ún. elsőfajú és másodfajú Stirling-számok értelmezését megelőzően bevezetünk néhány szükséges fogalmat.

Legyen $A$ egy tetszőleges véges halmaz és legyen $B_{1}, B_{2}, \ldots, B_{p}$ az $A$ halmaz valamely diszjunkt felbontása, vagyis $A$-nak egy olyan felbontása, amelyben az említettek olyan nem üres részhalmazok, amelyek egyesítése az $A$ halmaz és közülük bármely kettőnek a metszete az üres halmaz (páronként diszjunktak). Ebben az esetben azt mondjuk, hogy $B_{1}, B_{2}, \ldots, B_{p}$ halmazok az A halmaz egy osztályfelbontását (vagy partícióját) alkotják. A $B_{i}$ részhalmazokat osztályoknak vagy blokkoknak nevezzük.

Legyen $A$ egy $n$ elemü (véges) halmaz. Az $A$ bármely permutációja egy $\sigma: A \rightarrow A$ bijekció. Minden $n$-edfokú permutáció fixen hagyhat egyeseket az $1,2, \ldots, n$ elemek közül, míg másokat ténylegesen áthelyezhet. Ciklusnak nevezünk egy olyan permutációt, amelyet elég sokszor megismételve az általa ténylegesen áthelyezett elemek mindegyikét átvihetjük ezen elemek bármelyikébe.

Minden $n$-edfokú permutáció felbontható ciklusokra és ez a felbontás egyértelmü, eltekintve a ciklusok sorrendjétől és a ciklusok kezdőelemétől.

Azt mondjuk, hogy a $\sigma$ n-edfokú permutáció típusa $\left(k_{1}, k_{2}, \ldots, k_{n}\right)$, ha $\sigma$ felbontható $k_{1}$ darab 1 hosszúságú, $k_{2}$ darab 2 hosszúságú, ..., $k_{n}$ darab $n$ hosszúságú diszjunkt ciklusra, ahol $k_{1}+2 \cdot k_{2}+\ldots+n \cdot k_{n}=n$.

Tétel (Cauchy)

A $\left(k_{1}, k_{2}, \ldots, k_{n}\right)$ típusú $n$-edfokú permutációk száma:

$$
T\left(k_{1}, k_{2}, \ldots, k_{n}\right)=\frac{n !}{k_{1} ! k_{2} ! \ldots \cdot k_{n} ! 1^{k_{1}} \cdot 2^{k_{2}} \cdot \ldots \cdot n^{k_{n}}} .
$$

(a tétel bizonyítása [14] 32. o.)

Ezek után rátérünk a Stirling-számok értelmezésére (lásd [14] 30-35. o.).

\section{Definíció}

Legyen $1 \leq k \leq n$. Elsőfajú Stirling-számnak nevezzük azoknak az n-edfokú permutációknak a számát, amelyek $k$ darab ciklust tartalmaznak. Jelölése: $s(n, k)$.

\section{$\underline{\text { 3. Definíció }}$}

Legyenek $n \geq 1$ és $k \geq 1$. Másodfajú Stirling-számnak nevezzük egy $n$-elemü halmaz $k$ részhalmazra való osztályfelbontásainak számát. Jelölése: $S(n, k)$.

\section{Definíció}

Az összes partíciók száma a $B(n)$-nel jelölt ún. Bell-szám, amelyre $B(n)=\sum_{k=1}^{n} S(n, k)($ a $B(n)$ voltaképpen nem más, mint egy $n$ elemü halmazon értelmezhető ekvivalenciarelációk száma).

A 2. definícióból azonnal következik, hogy $s(n, n)=1$ (az identikus permutáció, amelyben minden elem a helyén marad). 
Teljesül továbbá egyfelöl, hogy $s(n, 1)=(n-1)$ ! (mert, ha egy ciklus van, azaz ciklikus permutációról van szó, akkor a típus $(0,0, \ldots, 0,1)$ és a Cauchy-tétel alapján $\left.T(0,0, \ldots, 0,1)=\frac{n !}{n}=(n-1) !\right)$.

Másrészt $s(n, n-1)=\left(\begin{array}{l}n \\ 2\end{array}\right)$, hiszen, ha a ciklusok száma $n-1$, akkor a típus $(n-2,1, \ldots, 0,0)$ és a Cauchy-tétel alapján $T(n-2,1, \ldots, 0,0)=\frac{n !}{(n-2) ! 2^{1}}=\frac{n(n-1)}{2}=\left(\begin{array}{l}n \\ 2\end{array}\right)$.

Megállapodás szerint $s(n, 0)=0$, minden $n \geq 1$ esetén és $s(0,0)=1$.

Az elsőfajú Stirling-szám értelmezéséből következik, hogy $\sum_{k=1}^{n} s(n, k)=n$ !, ahol $n \geq 1$.

Megállapodás szerint $S(n, 0)=0$, minden $n \geq 1$ esetén és $S(0,0)=1$.

Az előbbiek alapján $B(0)=S(0,0)=1$.

A másodfajú Stirling-szám definíciójából azonnal következik, hogy ha $n<k$, akkor $S(n, k)=0$. Fennállnak továbbá az $S(n, 1)=1$ és $S(n, n)=1$ egyenlőségek, ha $n \geq 1$.

Megemlítjük, hogy az elsőfajú Stirling-számok $n$ elem $k$ ciklusba való rendezhetőségeinek számát adják meg, míg a másodfajú Stirling-számok $n$ elem $k$ nemüres részhalmazba történő elrendezéseinek számát mutatják.

2. Tétel

Ha $n \geq 2$, akkor

a) $S(n, 2)=2^{n-1}-1$.

b) $S(n, n-1)=\left(\begin{array}{l}n \\ 2\end{array}\right)$.

Bizonyítás:

a) $\mathrm{Az} A$ halmazt két nemüres valódi részhalmazra kell bontanunk. Egy valódi részhalmazt $\left(2^{n}-2\right)$-féleképpen lehet kiválasztani (az üres halmaz és az $A$ nem jók), ekkor a másik (kiegészítö) részhalmaz meghatározott. Azonban a két részhalmaz sorrendje nem lényeges, ezért a lehetőségek száma $2^{n}-2$ fele lesz, azaz $2^{n-1}-1$.

b) Hasonló módon eljárva, $A$ minden $n-1$ osztályból álló partíciója tartalmaz egy kételemű és $n-2$ darab egyelemü osztályt. Figyelembe véve, hogy $n$ elemből két elem $\left(\begin{array}{l}n \\ 2\end{array}\right)$ módon választható ki, megkapjuk a bizonyítandó összefüggést.

Q.e.d.

Példák két részhalmazra történő partícionálásra:

1) Ha $A=\{a, b, c\}$, akkor a partíciók $\{a\} \cup\{b, c\},\{b\} \cup\{a, c\},\{c\} \cup\{a, b\}$, ezek száma $2^{3-1}-1=3$.

2) Ha $A=\{a, b, c, d\}$, akkor a partíciók $\{a\} \cup\{b, c, d\}, \quad\{b\} \cup\{a, c, d\}, \quad\{c\} \cup\{a, b, d\}$, $\{d\} \cup\{a, b, c\},\{a, b\} \cup\{c, d\},\{a, c\} \cup\{b, d\},\{a, d\} \cup\{b, c\}$, ezek száma $2^{4-1}-1=7$. 


\section{Tétel}

Ha $1 \leq k \leq n$, akkor

$$
s(n, k)=(n-1) \cdot s(n-1, k)+s(n-1, k-1) .
$$

Bizonyítás:

Ha $k=1$, akkor $s(n, 1)=(n-1) \cdot s(n-1,1)+s(n-1,0)$ kell, hogy teljesüljön.

Ha $n=1$, akkor $s(1,1)=1=0+1$, tehát igaz.

Ha $n \geq 2$, akkor $s(n, 1)=(n-1) !=(n-1) \cdot(n-2) !+0=(n-1) \cdot s(n-1,1)+s(n-1,0)$, tehát igaz.

Legyen $2 \leq k \leq n$.

Tekintsük a $k$ ciklust tartalmazó $n$-edfokú permutációkat. Számoljuk meg ezeket az alapján, hogy $n$ fixpont-e (azaz $(n)$ ciklus-e), vagy sem.

Ha $(n)$ ciklus, akkor marad $n-1$ elem, amely $k-1$ ciklust alkot. Az ilyen permutációk száma $s(n-1, k-1)$.

Ha $(n)$ nem ciklus, akkor az $n$ tagja egy legalább 2 hosszúságú ciklusnak. Legyen $\sigma$ egy $k$ ciklusú $(n-1)$-edfokú permutáció. Az $n$ ilyenkor beírható bármely $x$ szám után a $\sigma$ ciklusokra való felbontásában és így egy $n$-edfokú permutációt kapunk, amelyben az $n$ nem fixpont. Ilyenkor $s(n-1, k)$ lehetőség van a $\sigma$ kiválasztására és $(n-1)$ lehetőség van az $x$ szám megválasztására. Az ilyen permutációk száma tehát $(n-1) \cdot s(n-1, k)$. Összefoglalva, tehát a $k$ ciklust tartalmazó $n$-edfokú permutációk száma egyenlő $s(n-1, k-1)+(n-1) \cdot s(n-1, k)$.

Q.e.d.

A 3.4.1. táblázatban az elsőfajú Stirling-számok szerepelnek, a $0 \leq k, n \leq 6$ esetén,

\begin{tabular}{|c|c|c|c|c|c|c|c|}
\hline$s(n, k)$ & $k=0$ & $k=1$ & $k=2$ & $k=3$ & $k=4$ & $k=5$ & $k=6$ \\
\hline$n=0$ & 1 & 0 & 0 & 0 & 0 & 0 & 0 \\
\hline$n=1$ & 0 & 1 & 0 & 0 & 0 & 0 & 0 \\
\hline$n=2$ & 0 & 1 & 1 & 0 & 0 & 0 & 0 \\
\hline$n=3$ & 0 & 2 & 3 & 1 & 0 & 0 & 0 \\
\hline$n=4$ & 0 & 6 & 11 & 6 & 1 & 0 & 0 \\
\hline$n=5$ & 0 & 24 & 50 & 35 & 10 & 1 & 0 \\
\hline$n=6$ & 0 & 120 & 274 & 225 & 85 & 15 & 1 \\
\hline
\end{tabular}

3.4.1. táblázat Elsőfajú Stirling-számok $0 \leq k, n \leq 6$ esetén

illetve a 3.4.2. táblázatban ugyancsak az elsőfajú Stirling-számok az $1 \leq k, n \leq 6$ esetén, ezúttal a nullák elhagyásával. 


\begin{tabular}{|c|c|c|c|c|c|c|}
\hline$n$ & $s(n, 1)$ & $s(n, 2)$ & $s(n, 3)$ & $s(n, 4)$ & $s(n, 5)$ & $s(n, 6)$ \\
\hline 1 & 1 & & & & & \\
\hline 2 & 1 & 1 & & & & \\
\hline 3 & 2 & 3 & 1 & & & \\
\hline 4 & 6 & 11 & 6 & 1 & & \\
\hline 5 & 24 & 50 & 35 & 10 & 1 & \\
\hline 6 & 120 & 274 & 225 & 85 & 15 & 1 \\
\hline
\end{tabular}

3.4.2. táblázat Elsőfajú Stirling-számok $1 \leq k, n \leq 6$ esetén a nullák elhagyásával

\section{Megjegyzés}

Az elsőfajú Stirling-számoknál kapott rekurzív képlet nagyon hasonlít a binomiális együtthatók addíciós képletéhez, itt azonban megjelenik egy $(n-1)$-es szorzótényező is.

A (3.4.11) rekurzív képlet alapján minden $s(n, k)$ „belső szám” egyenlő a felette álló szám $(n-1)$-szeresének és annak baloldali szomszédjával vett összegével.

A „fóátló” minden eleme 1, míg a „főátló alatti átló” elemei a háromszögszámok.

\section{Tétel}

Ha $1 \leq k \leq n$, akkor

$$
S(n, k)=k \cdot S(n-1, k)+S(n-1, k-1) .
$$

Bizonyítás:

Ha $k=1$, akkor $S(n, 1)=1 \cdot S(n-1,1)+S(n-1,0)$ kell hogy teljesüljön.

Ha $n=1$, akkor $S(1,1)=1=0+1=S(0,1)+S(0,0)$, tehát igaz.

Ha $n \geq 2$, akkor $S(n, 1)=1=1+0=S(n-1,1)+S(n-1,0)$, tehát igaz.

Legyen $2 \leq k \leq n$.

Tekintsük egy $n$ elemű halmaz $k$ részhalmazra $(k$ blokkra) való osztályfelbontásait. Az $\{n\}$ vagy egy blokk, vagy nem.

Ha $\{n\}$ egy blokk, akkor $n-1$ elemet kell még $k-1$ blokkra osztani és ez $S(n-1, k-1)$ féleképpen lehetséges.

Ha $\{n\}$ nem blokk, akkor particionáljuk először az $\{1,2, \ldots, n-1\}$ halmazt $k$ blokkra , ezt $S(n-1, k)$-féleképpen lehet megtenni. Aztán minden blokkhoz vegyük hozzá az $n$ elemet, ezt pedig $k$-féleképpen tudjuk megtenni.

Összefoglalva a partíciók száma $S(n-1, k-1)+k \cdot S(n-1, k)$.

Q.e.d. 
A 3.4.3. táblázatban a másodfajú Stirling-számok szerepelnek, a $0 \leq k, n \leq 6$ esetekben,

\begin{tabular}{|c|c|c|c|c|c|c|c|}
\hline$S(n, k)$ & $k=0$ & $k=1$ & $k=2$ & $k=3$ & $k=4$ & $k=5$ & $k=6$ \\
\hline$n=0$ & 1 & 0 & 0 & 0 & 0 & 0 & 0 \\
\hline$n=1$ & 0 & 1 & 0 & 0 & 0 & 0 & 0 \\
\hline$n=2$ & 0 & 1 & 1 & 0 & 0 & 0 & 0 \\
\hline$n=3$ & 0 & 1 & 3 & 1 & 0 & 0 & 0 \\
\hline$n=4$ & 0 & 1 & 7 & 6 & 1 & 0 & 0 \\
\hline$n=5$ & 0 & 1 & 15 & 25 & 10 & 1 & 0 \\
\hline$n=6$ & 0 & 1 & 31 & 90 & 65 & 15 & 1 \\
\hline
\end{tabular}

3.4.3. táblázat Másodfajú Stirling-számok $0 \leq k, n \leq 6$ esetén

illetve a 3.4.4. táblázatban ismét a másodfajú Stirling-számok találhatók az $1 \leq k, n \leq 6$ esetén, a nullák elhagyásával.

\begin{tabular}{|c|c|c|c|c|c|c|}
\hline$n$ & $S(n, 1)$ & $S(n, 2)$ & $S(n, 3)$ & $S(n, 4)$ & $S(n, 5)$ & $S(n, 6)$ \\
\hline 1 & 1 & & & & & \\
\hline 2 & 1 & 1 & & & & \\
\hline 3 & 1 & 3 & 1 & & & \\
\hline 4 & 1 & 7 & 6 & 1 & & \\
\hline 5 & 1 & 15 & 25 & 10 & 1 & \\
\hline 6 & 1 & 31 & 90 & 65 & 15 & 1 \\
\hline
\end{tabular}

3.4.4. táblázat Másodfajú Stirling-számok $1 \leq k, n \leq 6$ esetén a nullák elhagyásával

\section{Megjegyzés}

Akárcsak az elsőfajú Stirling-számoknál, a másodfajú Stirling-számok esetén kapott rekurzív képlet is nagyon hasonlít a binomiális együtthatók addíciós képletéhez, itt azonban megjelent egy $k$ szorzótényező is. A (3.4.12) rekurzív képlet alapján minden $S(n, k)$ „belső szám” a felette álló szám $k$-szorosa és annak baloldali szomszédja összegével egyenlő.

A „főátló” minden eleme 1, míg a „fóátló alatti átló” elemei a háromszögszámok lesznek.

A folytatásban a Bell-számokra mutatunk be egy rekurziót.

\section{Tétel}

Ha $n \geq 0$, akkor

$$
B(n+1)=\sum_{k=0}^{n}\left(\begin{array}{l}
n \\
k
\end{array}\right) \cdot B(k) \text {. }
$$

Bizonyítás:

Vizsgáljuk meg az $\{1,2, \ldots, n, n+1\}$ halmaz partícióit az alapján, hogy az $(n+1)$-edik elem blokkja hány elemet is tartalmaz! 
Tegyük fel, hogy az $(n+1)$-edik elem blokkjában az elemek száma $i$, ahol $1 \leq i \leq n+1$. Ilyenkor a blokk többi $i-1$ elemét $\left(\begin{array}{c}n \\ i-1\end{array}\right)$-féleképpen lehet kiválasztani. Ha ez megtörtént, akkor a további $n+1-i$ elemet $B(n+1-i)$-féleképpen lehet particionálni (ha az $i=n+1$, akkor $n+1-i=0$, ezért van szükség a $B(0)=1-$ re). Figyelembe véve azt is, hogy $\left(\begin{array}{c}n \\ i-1\end{array}\right)=\left(\begin{array}{c}n \\ n+1-i\end{array}\right)$, az alábbi ,hármas” egyenlőséget kapjuk:

$$
B(n+1)=\sum_{i=1}^{n+1}\left(\begin{array}{c}
n \\
i-1
\end{array}\right) \cdot B(n+1-i)=\sum_{i=1}^{n+1}\left(\begin{array}{c}
n \\
n+1-i
\end{array}\right) \cdot B(n+1-i)=\sum_{k=0}^{n}\left(\begin{array}{l}
n \\
k
\end{array}\right) \cdot B(k),
$$

ahol az utolsó a $k=n+1-i$ indexcserének megfelelően adódott.

Q.e.d.

A 3.4.5. táblázat az első tíz Bell-szám értékét tartalmazza.

\begin{tabular}{|l|c|c|c|c|c|c|c|c|c|c|}
\hline & $n=0$ & $n=1$ & $n=2$ & $n=3$ & $n=4$ & $n=5$ & $n=6$ & $n=7$ & $n=8$ & $n=9$ \\
\hline$B(n)$ & 1 & 1 & 2 & 5 & 15 & 52 & 203 & 877 & 4140 & 21147 \\
\hline
\end{tabular}

3.4.5. táblázat Az első tíz Bell-szám

\section{$\underline{\text { 6. Tétel }}$}

Ha $n \geq 1$, akkor

$$
[x]_{n}=\sum_{k=1}^{n}(-1)^{n-k} \cdot s(n, k) \cdot x^{k},
$$

ahol $[x]_{n}=x(x-1) \ldots(x-n+1)$.

Bizonyítás:

Az összefüggés igazolása a teljes indukció módszerével történik.

Ha $n=1 \quad[x]_{1}=s(1,1) \cdot x^{1}$, azaz $x=1 \cdot x$, ami igaz, tehát $n=1$ esetben teljesül.

Ha $n=2 \quad[x]_{2}=-s(2,1) \cdot x^{1}+s(2,2) \cdot x^{2}, \quad$ vagyis $\quad x(x-1)=-1 \cdot x+1 \cdot x^{2}, \quad$ ami $\quad$ egy azonosság, tehát $n=2$ esetben szintén igaz.

Tegyük fel, hogy az összefüggés igaz $(n-1)$-re, azaz fennáll, hogy $[x]_{n-1}=\sum_{k=1}^{n-1}(-1)^{n-1-k} \cdot s(n-1, k) \cdot x^{k}$. Igazoljuk, hogy hasonló teljesül $n$-re is.

Felhasználva a (3.4.11) összefüggést és azt is, hogy $s(n, 0)=0$, minden $n \geq 1$ esetén a következőket kapjuk:

$$
\begin{aligned}
& \sum_{k=1}^{n}(-1)^{n-k} \cdot s(n, k) \cdot x^{k}=s(n, n) \cdot x^{n}+\sum_{k=1}^{n-1}(-1)^{n-k} \cdot s(n, k) \cdot x^{k}= \\
& =s(n, n) \cdot x^{n}+\sum_{k=1}^{n-1}(-1)^{n-k} \cdot[(n-1) \cdot s(n-1, k)+s(n-1, k-1)] \cdot x^{k}= \\
& =s(n, n) \cdot x^{n}+\sum_{k=2}^{n-1}(-1)^{n-k} \cdot s(n-1, k-1) \cdot x^{k}+(n-1) \cdot \sum_{k=1}^{n-1}(-1)^{n-k} \cdot s(n-1, k) \cdot x^{k} .
\end{aligned}
$$


Figyelembe véve, hogy $n \geq 1$ esetén $s(n, n)=s(n-1, n-1)=1$ és a (3.4.15) összefüggésben a $j=k-1$ egyenlőség szerint cserélve:

$$
\begin{aligned}
& \sum_{k=1}^{n}(-1)^{n-k} \cdot s(n, k) \cdot x^{k}=\sum_{k=2}^{n}(-1)^{n-k} \cdot s(n-1, k-1) \cdot x^{k}+(n-1) \cdot \sum_{k=1}^{n-1}(-1)^{n-k} \cdot s(n-1, k) \cdot x^{k}= \\
& =\sum_{j=1}^{n-1}(-1)^{n-j-1} \cdot s(n-1, j) \cdot x^{j+1}+(n-1) \cdot \sum_{k=1}^{n-1}(-1)^{n-k} \cdot s(n-1, k) \cdot x^{k}= \\
& =x \cdot \sum_{j=1}^{n-1}(-1)^{n-1-j} \cdot s(n-1, j) \cdot x^{j}-(n-1) \cdot \sum_{k=1}^{n-1}(-1)^{n-1-k} \cdot s(n-1, k) \cdot x^{k}= \\
& =(x-n+1) \cdot \sum_{k=1}^{n-1}(-1)^{n-1-k} \cdot s(n-1, k) \cdot x^{k}=(x-n+1) \cdot[x]_{n-1}=[x]_{n},
\end{aligned}
$$

ahol felhasználtuk azt is, hogy az indukciós feltétel szerint $\sum_{k=1}^{n-1}(-1)^{n-1-k} \cdot s(n-1, k) \cdot x^{k}=[x]_{n-1}$.

Q.e.d.

\section{Megjegyzés}

Egyes szerzők a $(-1)^{n-k} \cdot s(n, k)$ számokat elsőfajú Stirling-számoknak, míg az $s(n, k)$ számokat elsőfajú abszolút Stirling-számoknak nevezik.

\section{Tétel}

Ha $n \geq 1$, akkor

$$
[x]^{n}=\sum_{k=1}^{n} s(n, k) \cdot x^{k},
$$

ahol $[x]^{n}=x(x+1) \ldots(x+n-1)$.

\section{Bizonyítás:}

A (3.4.14) összefüggésben az $x$ helyére írjunk $(-x)$-et: $[-x]_{n}=\sum_{k=1}^{n}(-1)^{n-k} \cdot s(n, k) \cdot(-x)^{k}$.

Azonban

$$
[-x]_{n}=(-x)(-x-1)(-x-2) \ldots(-x-n+1)=(-1)^{n} \cdot x(x+1)(x+2) \ldots(x+n-1)=(-1)^{n} \cdot[x]^{n},
$$

illetve

$$
\begin{aligned}
& \sum_{k=1}^{n}(-1)^{n-k} \cdot s(n, k) \cdot(-x)^{k}=\sum_{k=1}^{n}(-1)^{n-k} \cdot s(n, k) \cdot(-1)^{k} \cdot x^{k}=\sum_{k=1}^{n}(-1)^{n} \cdot s(n, k) \cdot x^{k}= \\
& =(-1)^{n} \cdot \sum_{k=1}^{n} s(n, k) \cdot x^{k} .
\end{aligned}
$$

Mindezek alapján

$$
\begin{aligned}
& (-1)^{n} \cdot[x]^{n}=[-x]_{n}=\sum_{k=1}^{n}(-1)^{n-k} \cdot s(n, k) \cdot(-x)^{k}=(-1)^{n} \cdot \sum_{k=1}^{n} s(n, k) \cdot x^{k} . \\
& (-1)^{n} \cdot[x]^{n}=(-1)^{n} \cdot \sum_{k=1}^{n} s(n, k) \cdot x^{k} \\
& \text { ahonnan }[x]^{n}=\sum_{k=1}^{n} s(n, k) \cdot x^{k} .
\end{aligned}
$$

Q.e.d. 


\section{Tétel}

Ha $n \geq 1$, akkor

$$
x^{n}=\sum_{k=1}^{n} S(n, k) \cdot[x]_{k},
$$

ahol $[x]_{k}=x(x-1) \ldots(x-k+1)$.

\section{Bizonyítás:}

Az összefüggés igazolása a teljes indukció módszerével történik.

Ha $n=1 \quad x^{1}=S(1,1) \cdot[x]_{1}$, vagyis $x=1 \cdot x$, tehát $n=1$ esetben igaz.

Ha $n=2 \quad x^{2}=S(2,1) \cdot[x]_{1}+S(2,2) \cdot[x]_{2}, \quad$ vagyis $\quad x^{2}=1 \cdot x+1 \cdot x(x-1), \quad$ ami $\quad$ egy azonosság, tehát $n=2$ esetén szintén igaz.

Tegyük fel, hogy az összefüggés igaz $(n-1)$-re, tehát $x^{n-1}=\sum_{k=1}^{n-1} S(n-1, k) \cdot[x]_{k}$. Igazolandó, hogy hasonló teljesül $n$-re is.

Felhasználva a (3.4.12) összefüggést és azt, hogy $S(n, 0)=0$, minden $n \geq 1$ esetén

$$
\begin{aligned}
& \sum_{k=1}^{n} S(n, k) \cdot[x]_{k}=S(n, n) \cdot[x]_{n}+\sum_{k=1}^{n-1} S(n, k) \cdot[x]_{k}= \\
& =S(n, n) \cdot[x]_{n}+\sum_{k=1}^{n-1}(k \cdot S(n-1, k)+S(n-1, k-1)) \cdot[x]_{k}= \\
& =S(n, n) \cdot[x]_{n}+\sum_{k=1}^{n-1} k \cdot S(n-1, k) \cdot[x]_{k}+\sum_{k=2}^{n-1} S(n-1, k-1) \cdot[x]_{k} .
\end{aligned}
$$

Mivel $n \geq 1$ esetén $S(n, n)=S(n-1, n-1)=1$ és $[x]_{k}=[x]_{k-1} \cdot(x-k+1)$, ezért a (3.4.18) összefüggés átírható a következőképpen:

$$
\begin{aligned}
& \sum_{k=1}^{n} S(n, k) \cdot[x]_{k}=S(n-1, n-1) \cdot[x]_{n}+\sum_{k=1}^{n-1} k \cdot S(n-1, k) \cdot[x]_{k}+\sum_{k=2}^{n-1} S(n-1, k-1) \cdot[x]_{k-1} \cdot(x-k+1)= \\
& =\sum_{k=1}^{n-1} k \cdot S(n-1, k) \cdot[x]_{k}+S(n-1, n-1) \cdot[x]_{n}+\sum_{k=2}^{n-1} S(n-1, k-1) \cdot[x]_{k-1} \cdot(x-k+1) .
\end{aligned}
$$

A (3.4.19) összefüggésben a $j=k-1$ egyenlőség szerint cserélve az alábbiakat kapjuk:

$$
\begin{aligned}
& \sum_{k=1}^{n} S(n, k) \cdot[x]_{k}=\sum_{k=1}^{n-1} k \cdot S(n-1, k) \cdot[x]_{k}+S(n-1, n-1) \cdot[x]_{n}+\sum_{j=1}^{n-2} S(n-1, j) \cdot[x]_{j} \cdot(x-j)= \\
& =\sum_{k=1}^{n-1} k \cdot S(n-1, k) \cdot[x]_{k}+\sum_{j=1}^{n-1} S(n-1, j) \cdot[x]_{j} \cdot(x-j)= \\
& =\sum_{k=1}^{n-1} k \cdot S(n-1, k) \cdot[x]_{k}+x \cdot \sum_{j=1}^{n-1} S(n-1, j) \cdot[x]_{j}-\sum_{j=1}^{n-1} j \cdot S(n-1, j) \cdot[x]_{j}=x \cdot \sum_{j=1}^{n-1} S(n-1, j) \cdot[x]_{j}= \\
& =x \cdot x^{n-1}=x^{n},
\end{aligned}
$$

ahol felhasználtuk azt a tényt, hogy az indukciós feltétel szerint $\sum_{j=1}^{n-1} S(n-1, j) \cdot[x]_{j}=x^{n-1}$.

Q.e.d. 


\section{Tétel}

Ha $n \geq 1$, akkor

$$
H_{n}=\frac{1}{n !} \cdot s(n+1,2) \text {, }
$$

ahol $H_{n}=1+\frac{1}{2}+\frac{1}{3}+\ldots+\frac{1}{n}$ jelöli az ún. harmonikus számokat.

Bizonyítás:

Az összefüggés igazolása a teljes indukció módszerével történik.

Ha $n=1 \quad H_{1}=\frac{1}{1 !} \cdot s(2,2)=1 \cdot 1=1$, tehát igaz.

Ha $n=2 \quad H_{2}=\frac{1}{2 !} \cdot s(3,2)=\frac{1}{2} \cdot 3=1+\frac{1}{2}$, tehát igaz.

Tegyük fel, hogy az összefüggés igaz $(n-1)$-re, tehát $H_{n-1}=\frac{1}{(n-1) !} \cdot s(n, 2)$. Bizonyítandó, hogy hasonló teljesül $n$-re is, azaz fennáll a $H_{n}=\frac{1}{n !} \cdot s(n+1,2)$ egyenlőség.

Felírható, hogy $H_{n}=H_{n-1}+\frac{1}{n}=\frac{1}{(n-1) !} \cdot s(n, 2)+\frac{1}{n}=\frac{n \cdot s(n, 2)+(n-1) !}{n !}$.

Felhasználva azt, hogy $s(n, 1)=(n-1)$ !, a (3.4.11) összefüggés alapján

$$
H_{n}=\frac{n \cdot s(n, 2)+(n-1) !}{n !}=\frac{n \cdot s(n, 2)+s(n, 1)}{n !}=\frac{s(n+1,2)}{n !}
$$

és ez az, amit bizonyítani akartunk.

Q.e.d.

\section{Megjegyzés}

A Bell- és a Stirling-féle számokkal kapcsolatban további tulajdonságok és összefüggések találhatóak, a [3]-ban 49-52. o. és 65-72. o., valamint [13]-ban 45-54. o. és 138-142. o. .

\section{Megjegyzés}

Ha $H_{n}^{*}$ jelöli az első $n$ pozitív egész szám reciprokainak alternáló összegét - vagyis $H_{n}^{*}=\sum_{k=1}^{n}(-1)^{k-1} \cdot \frac{1}{k}-$, akkor teljesül az ún. Catalan-összefüggés:

$$
H_{2 n}^{*}=H_{2 n}-H_{n},
$$

azaz

$$
1-\frac{1}{2}+\frac{1}{3}-\frac{1}{4}+\ldots+\frac{1}{2 n-1}-\frac{1}{2 n}=\frac{1}{n+1}+\frac{1}{n+2}+\ldots+\frac{1}{2 n} .
$$

A Catalan-összefüggés bizonyítása, néhány alkalmazása és különböző általánosítások megtalálhatók [23]-ban és [24]-ben. 
Ebben a fejezetben először bevezettük az emelkedő és süllyedő faktoriálisok fogalmát. Az emelkedő faktoriális, valamint a szimmetrikus összegek segítségével levezettük a hatványösszegek közötti rekurziót, továbbá három konkrét eset vizsgálatával „kipróbáltuk” a kapott összefüggést. Bevezettuik a Bell-számok és a Stirling-féle (elsőfajú és másodfajú) számokat, majd ezekre ismét felírtunk egy-egy rekurziót. Ezután kapcsolatot teremtettünk a Stirling-féle számok, valamint az emelkedő/süllyedő faktoriálisok között. Az emelkedő faktoriális segítségével egyrészt fel tudtuk írni az $S_{p}$ összeget megadó rekurziós összefüggést, másrészt az emelkedő és a süllyedő faktoriális felhasználásával eljutottunk a Stirling- és Bellszámokhoz, melyek a matematika egy másik részterületének fontos alkotó elemei. S végül említsük meg, hogy e részvizsgálatok kisebb, de fontos hozadéka, hogy kapcsolatot teremtettünk a matematika két különbözö területe között. Az ilyen fajta összeköttetések, „hidak" felfedezése mind a középiskolai, mind pedig a felsőfokú matematikaoktatásban fontos gondolkodás- és szemléletformáló tényező.

\subsection{Rekurziós összefüggés felírása deriválással}

A következőkben némi kombinatorikai és függvénytani ismeretek, valamint a differenciálszámítás felhasználásával kíséreljük meg a korábbiakban már megismert rekurziós összefüggéseket meghatározni.

A levezetés gondolatmenete a következő: egy speciális szorzatfüggvénynek vesszük a $(p+1)$ edrendủ deriváltját, melyet a szorzatfüggvényre vonatkozó Leibniz-féle összefüggéssel írunk fel. A lehetséges összevonások után a kapott összefüggésben az $x$ helyébe nullát írunk és a binomiális együtthatók közötti azonosságokat felhasználva jutunk el a kívánt rekurzióhoz.

\subsubsection{Rekurziós összefüggés előállítása differenciálszámítás segítségével}

Az ismertetésre kerülő módszer levezetése előtt két tételt mutatunk be, melyekre szükségünk lesz a számításainkban.

\section{$\underline{10 . ~ T e ́ t e l ~}$}

Ha $c \neq 0$ egy valós szám, akkor az $f: R \rightarrow R^{+}, f(x)=e^{c \cdot x}$ függvény $m$-szer deriválható az $R$-n és $f^{(m)}(x)=c^{m} \cdot e^{c \cdot x}$, ahol $m$ egy tetszőleges pozitív egész.

\section{Tétel (Leibniz)}

Legyenek $g$ és $h m$-szer deriválható függvények $R$-n. Akkor a $g \cdot h: R \rightarrow R$ szorzatfüggvény szintén $m$-szer deriválható az $R$-n és teljesül a Leibniz-féle összefüggés:

$$
(g \cdot h)^{(m)}=\sum_{i=0}^{m}\left(\begin{array}{c}
m \\
i
\end{array}\right) \cdot g^{(m-i)} \cdot h^{(i)},
$$

bármely $m \in N$ esetén.

A tételek bizonyítása, mely a teljes indukció módszerével történik megtalálható a [10] 201. o., illetve [11] 134. o. .

Ezek után térjünk rá a rekurziós összefüggés levezetésére. 
Legyen adott a következö függvény: $F_{n}: R \rightarrow R^{+}, F_{n}(x)=\sum_{l=1}^{n} e^{l \cdot x}$, ahol $n \in Z^{+}$.

Ekkor $\left(e^{x}-1\right) \cdot F_{n}(x)=\left(e^{x}-1\right) \cdot \sum_{l=1}^{n} e^{l \cdot x}=\sum_{l=1}^{n}\left[e^{(l+1) \cdot x}-e^{l \cdot x}\right]$.

A $\sum_{l=1}^{n}\left[e^{(l+1) \cdot x}-e^{l \cdot x}\right]$ egy teleszkópikus összeg, amely az összevonások után $e^{(n+1) \cdot x}-e^{x}$ és így

$$
\left(e^{x}-1\right) \cdot F_{n}(x)=e^{(n+1) \cdot x}-e^{x},
$$

minden $n$ pozitív egész szám esetén.

Ha a (3.5.2) összefüggés mindkét oldalán szereplő függvényeknek vesszük a $(p+1)$-edrendü deriváltját, ahol $p \in N$, akkor a (3.5.1) figyelembevételével felírható, hogy

$$
(n+1)^{p+1} \cdot e^{(n+1) \cdot x}-e^{x}=\sum_{i=0}^{p+1}\left(\begin{array}{c}
p+1 \\
i
\end{array}\right) \cdot\left(e^{x}-1\right)^{(p+1-i)} \cdot\left[F_{n}(x)\right]^{(i)} .
$$

Egyfelöl $\left(e^{x}-1\right)^{(p+1-i)}=e^{x}$, ha $p+1-i \geq 1-$ azaz $0 \leq i \leq p-$ és $\left(e^{x}-1\right)^{(p+1-i)}=e^{x}-1$, ha $i=p+1$, másrészt pedig

$$
\left[F_{n}(x)\right]^{(i)}=\left(e^{x}+e^{2 \cdot x}+e^{3 \cdot x}+\ldots+e^{n \cdot x}\right)^{(i)}=e^{x}+2^{i} \cdot e^{2 \cdot x}+3^{i} \cdot e^{3 \cdot x}+\ldots+n^{i} \cdot e^{n \cdot x}=\sum_{k=1}^{n} k^{i} \cdot e^{k \cdot x} .
$$

Mindezek alapján és figyelembe véve, hogy $\left(\begin{array}{l}p+1 \\ p+1\end{array}\right)=1$, a (3.5.3) összefüggés átalakul

$$
\begin{aligned}
& (n+1)^{p+1} \cdot e^{(n+1) \cdot x}-e^{x}=\sum_{i=0}^{p+1}\left[\left(\begin{array}{c}
p+1 \\
i
\end{array}\right) \cdot\left(e^{x}-1\right)^{(p+1-i)} \cdot\left(\sum_{k=1}^{n} k^{i} \cdot e^{k \cdot x}\right)\right]= \\
& =\sum_{i=0}^{p}\left[\left(\begin{array}{c}
p+1 \\
i
\end{array}\right) \cdot\left(e^{x}-1\right)^{(p+1-i)} \cdot\left(\sum_{k=1}^{n} k^{i} \cdot e^{k \cdot x}\right)\right]+\left(\begin{array}{c}
p+1 \\
p+1
\end{array}\right) \cdot\left(e^{x}-1\right) \cdot\left(\sum_{k=1}^{n} k^{p+1} \cdot e^{k \cdot x}\right)= \\
& =\sum_{i=0}^{p}\left[\left(\begin{array}{c}
p+1 \\
i
\end{array}\right) \cdot e^{x} \cdot\left(\sum_{k=1}^{n} k^{i} \cdot e^{k \cdot x}\right)\right]+\left(e^{x}-1\right) \cdot\left(\sum_{k=1}^{n} k^{p+1} \cdot e^{k \cdot x}\right)= \\
& =\sum_{i=0}^{p} \sum_{k=1}^{n}\left(\begin{array}{c}
p+1 \\
i
\end{array}\right) \cdot k^{i} \cdot e^{k \cdot x} \cdot e^{x}+\left(e^{x}-1\right) \cdot\left(\sum_{k=1}^{n} k^{p+1} \cdot e^{k \cdot x}\right) .
\end{aligned}
$$

Tehát:

$$
(n+1)^{p+1} \cdot e^{(n+1) \cdot x}-e^{x}=\sum_{i=0}^{p} \sum_{k=1}^{n}\left(\begin{array}{c}
p+1 \\
i
\end{array}\right) \cdot k^{i} \cdot e^{(k+1) \cdot x}+\left(e^{x}-1\right) \cdot\left(\sum_{k=1}^{n} k^{p+1} \cdot e^{k \cdot x}\right) .
$$

Ha a (3.5.4) összefüggésben az $x$ helyébe 0 -t írunk és felhasználva, hogy $e^{0}=1$ kapjuk hogy

$$
\begin{aligned}
& (n+1)^{p+1} \cdot 1-1=\sum_{i=0}^{p} \sum_{k=1}^{n}\left(\begin{array}{c}
p+1 \\
i
\end{array}\right) \cdot k^{i} \cdot 1+(1-1) \cdot\left(\sum_{k=1}^{n} k^{p+1} \cdot 1\right), \\
& (n+1)^{p+1}-1=\sum_{i=0}^{p} \sum_{k=1}^{n}\left(\begin{array}{c}
p+1 \\
i
\end{array}\right) \cdot k^{i}=\sum_{i=0}^{p}\left[\left(\begin{array}{c}
p+1 \\
i
\end{array}\right) \cdot\left(\sum_{k=1}^{n} k^{i}\right)\right]=\sum_{i=0}^{p}\left(\begin{array}{c}
p+1 \\
i
\end{array}\right) \cdot S_{i},
\end{aligned}
$$

azaz 


$$
(n+1)^{p+1}-1=\left(\begin{array}{c}
p+1 \\
0
\end{array}\right) \cdot S_{0}+\left(\begin{array}{c}
p+1 \\
1
\end{array}\right) \cdot S_{1}+\left(\begin{array}{c}
p+1 \\
2
\end{array}\right) \cdot S_{2}+\ldots+\left(\begin{array}{c}
p+1 \\
p-1
\end{array}\right) \cdot S_{p-1}+\left(\begin{array}{c}
p+1 \\
p
\end{array}\right) \cdot S_{p}
$$

Mivel $S_{0}=n,\left(\begin{array}{c}p+1 \\ 0\end{array}\right)=1$ és $\left(\begin{array}{c}p+1 \\ p\end{array}\right)=p+1$, átrendezés után

$$
(p+1) \cdot S_{p}=(n+1)^{p+1}-(n+1)-\left(\begin{array}{c}
p+1 \\
1
\end{array}\right) \cdot S_{1}-\left(\begin{array}{c}
p+1 \\
2
\end{array}\right) \cdot S_{2}-\ldots-\left(\begin{array}{c}
p+1 \\
p-1
\end{array}\right) \cdot S_{p-1} .
$$

Figyelembe véve, hogy $\left(\begin{array}{c}p+1 \\ p+1\end{array}\right)=1$, illetve $\left(\begin{array}{c}p+1 \\ i\end{array}\right)=\left(\begin{array}{c}p+1 \\ p+1-i\end{array}\right)$, ahol $i=1,2, \ldots, p$, a (3.5.5) összefüggés átírható az alábbi alakra is:

$$
(p+1) \cdot S_{p}=(n+1)^{p+1}-\left(\begin{array}{c}
p+1 \\
2
\end{array}\right) \cdot S_{p-1}-\left(\begin{array}{c}
p+1 \\
3
\end{array}\right) \cdot S_{p-2}-\ldots-\left(\begin{array}{c}
p+1 \\
p
\end{array}\right) \cdot S_{1}-\left(\begin{array}{c}
p+1 \\
p+1
\end{array}\right) \cdot(n+1),
$$

ami pontosan a 3.3.1. fejezet (3.3.1) összefüggése.

\subsection{2. Általánosítás a differenciálszámításon alapuló módszer segítségével a számtani sorozatok esetén}

A fent leírt módszer segítségével a következőkben általánosítunk a számtani sorozatok esetére.

Ehhez tekintsünk egy olyan $\left\{a_{n}\right\}_{n \geq 1}$ számtani sorozatot, melynek az első eleme $a$ és a differenciája pedig $d$, ahol $a, d \in R$. Vizsgáljuk meg, mit tudunk mondani a sorozat első $n$ tagja $p$-edik hatványainak összegéről, vagyis egy $p$-edrendủ számtani sorozat egymást követő tagjainak összegéről!

Legyen

$S_{p}(a, d)=a_{1}^{p}+a_{2}^{p}+a_{3}^{p}+\ldots+a_{n}^{p}=\sum_{i=1}^{n} a_{i}^{p}=\sum_{i=1}^{n}[a+(i-1) \cdot d]^{p}$,

ahol $p=0 ; 1 ; 2 ; \ldots$.

$S_{0}(a, d)$ kiszámításával ezúttal sem kell külön foglalkoznunk, hiszen könnyen belátható, hogy $S_{0}(a, d)=n$.

Az az eset, amikor $d=0$, tehát amikor a sorozat állandó, szintén könnyen elintézhető, hiszen ilyenkor $S_{p}(a, 0)=n \cdot a_{1}^{p}=n \cdot a^{p}$.

Legyen tehát $d \neq 0$. Az alábbi gondolatmenet megegyezik az $S_{p}$ kiszámítására az előzőekben már részletesen bemutatott eljárással.

Legyen adott a következő függvény: $F_{n}: R \rightarrow R^{+}, F_{n}(x)=\sum_{l=1}^{n} e^{a_{l} \cdot x}$, ahol $n \in Z^{+}$.

Ekkor $\left(e^{d \cdot x}-1\right) \cdot F_{n}(x)=\left(e^{d \cdot x}-1\right) \cdot \sum_{l=1}^{n} e^{a_{l} \cdot x}=\sum_{l=1}^{n}\left[e^{\left(a_{l}+d\right) \cdot x}-e^{a_{l} \cdot x}\right]=\sum_{l=1}^{n}\left[e^{a_{l+1} \cdot x}-e^{a_{l} \cdot x}\right]$. 
A $\sum_{l=1}^{n}\left[e^{a_{l+1} \cdot x}-e^{a_{l} \cdot x}\right]$ egy teleszkópikus összeg, amely az összevonások után $e^{a_{n+1} \cdot x}-e^{a_{1} \cdot x}=e^{(a+n d) \cdot x}-e^{a \cdot x}$ alakot ölti és így

$$
\left(e^{d \cdot x}-1\right) \cdot F_{n}(x)=e^{(a+n d) \cdot x}-e^{a \cdot x},
$$

minden $n$ pozitív egész szám esetén.

Ha a (3.5.6) összefüggés mindkét oldalán szereplő függvényeknek vesszük a $(p+1)$-edrendü deriváltját, ahol $p \in N$, akkor a (3.5.1) figyelembe vételével adódik, hogy

$$
(a+n d)^{p+1} \cdot e^{(a+n d) \cdot x}-a^{p+1} \cdot e^{a \cdot x}=\sum_{i=0}^{p+1}\left(\begin{array}{c}
p+1 \\
i
\end{array}\right) \cdot\left(e^{d \cdot x}-1\right)^{(p+1-i)} \cdot\left[F_{n}(x)\right]^{(i)} .
$$

Egyrészt $\left(e^{d \cdot x}-1\right)^{(p+1-i)}=d^{p+1-i} \cdot e^{d \cdot x}$, ha $p+1-i \geq 1-$ azaz $0 \leq i \leq p-$ és

$\left(e^{d \cdot x}-1\right)^{(p+1-i)}=e^{d \cdot x}-1$, ha $i=p+1$, másrészt pedig

$\left[F_{n}(x)\right]^{(i)}=\left(e^{a_{1} \cdot x}+e^{a_{2} \cdot x}+e^{a_{3} \cdot x}+\ldots+e^{a_{n} \cdot x}\right)^{(i)}=$

$=a_{1}^{i} \cdot e^{a_{1} \cdot x}+a_{2}^{i} \cdot e^{a_{2} \cdot x}+a_{3}^{i} \cdot e^{a_{3} \cdot x}+\ldots+a_{n}^{i} \cdot e^{a_{n} \cdot x}=\sum_{k=1}^{n} a_{k}^{i} \cdot e^{a_{k} \cdot x}$.

Mindezeket és azt figyelembe véve, hogy $\left(\begin{array}{c}p+1 \\ p+1\end{array}\right)=1$, a (3.5.7) összefüggés átalakul a következők szerint:

$$
\begin{aligned}
& (a+n d)^{p+1} \cdot e^{(a+n d) \cdot x}-a^{p+1} \cdot e^{a \cdot x}=\sum_{i=0}^{p+1}\left[\left(\begin{array}{c}
p+1 \\
i
\end{array}\right) \cdot\left(e^{d \cdot x}-1\right)^{(p+1-i)} \cdot\left(\sum_{k=1}^{n} a_{k}^{i} \cdot e^{a_{k} \cdot x}\right)\right]= \\
& =\sum_{i=0}^{p}\left[\left(\begin{array}{c}
p+1 \\
i
\end{array}\right) \cdot\left(e^{d \cdot x}-1\right)^{(p+1-i)} \cdot\left(\sum_{k=1}^{n} a_{k}^{i} \cdot e^{a_{k} \cdot x}\right)\right]+\left(\begin{array}{c}
p+1 \\
p+1
\end{array}\right) \cdot\left(e^{d \cdot x}-1\right) \cdot\left(\sum_{k=1}^{n} a_{k}^{p+1} \cdot e^{a_{k} \cdot x}\right)= \\
& =\sum_{i=0}^{p}\left[\left(\begin{array}{c}
p+1 \\
i
\end{array}\right) \cdot d^{p+1-i} \cdot e^{d \cdot x} \cdot\left(\sum_{k=1}^{n} a_{k}^{i} \cdot e^{a_{k} \cdot x}\right)\right]+\left(e^{d \cdot x}-1\right) \cdot\left(\sum_{k=1}^{n} a_{k}^{p+1} \cdot e^{a_{k} \cdot x}\right)= \\
& =\sum_{i=0}^{p} \sum_{k=1}^{n}\left(\begin{array}{c}
p+1 \\
i
\end{array}\right) \cdot d^{p+1-i} \cdot a_{k}^{i} \cdot e^{a_{k} \cdot x} \cdot e^{d \cdot x}+\left(e^{d \cdot x}-1\right) \cdot\left(\sum_{k=1}^{n} a_{k}^{p+1} \cdot e^{a_{k} \cdot x}\right) .
\end{aligned}
$$

Tehát felírható, hogy

$$
\begin{aligned}
& (a+n d)^{p+1} \cdot e^{(a+n d) \cdot x}-a^{p+1} \cdot e^{a \cdot x}= \\
& =\sum_{i=0}^{p} \sum_{k=1}^{n}\left(\begin{array}{c}
p+1 \\
i
\end{array}\right) \cdot d^{p+1-i} \cdot a_{k}^{i} \cdot e^{a_{k+1} \cdot x}+\left(e^{d \cdot x}-1\right) \cdot\left(\sum_{k=1}^{n} a_{k}^{p+1} \cdot e^{a_{k} \cdot x}\right) .
\end{aligned}
$$

Ha a (3.5.8) összefüggésben az $x$ helyébe 0-t írunk és felhasználva, hogy $e^{0}=1$ kapjuk hogy

$$
(a+n d)^{p+1} \cdot 1-a^{p+1} \cdot 1=\sum_{i=0}^{p} \sum_{k=1}^{n}\left(\begin{array}{c}
p+1 \\
i
\end{array}\right) \cdot d^{p+1-i} \cdot a_{k}^{i} \cdot 1+(1-1) \cdot\left(\sum_{k=1}^{n} a_{k}^{p+1} \cdot 1\right) .
$$




$$
\begin{aligned}
& (a+n d)^{p+1}-a^{p+1}=\sum_{i=0}^{p} \sum_{k=1}^{n}\left(\begin{array}{c}
p+1 \\
i
\end{array}\right) \cdot d^{p+1-i} \cdot a_{k}^{i}=\sum_{i=0}^{p}\left[\left(\begin{array}{c}
p+1 \\
i
\end{array}\right) \cdot d^{p+1-i} \cdot\left(\sum_{k=1}^{n} a_{k}^{i}\right)\right]= \\
& =\sum_{i=0}^{p}\left(\begin{array}{c}
p+1 \\
i
\end{array}\right) \cdot d^{p+1-i} \cdot S_{i}(a, d)
\end{aligned}
$$

azaz

$$
\begin{aligned}
& (a+n d)^{p+1}-a^{p+1}=\left(\begin{array}{c}
p+1 \\
0
\end{array}\right) \cdot d^{p+1} \cdot S_{0}(a, d)++\left(\begin{array}{c}
p+1 \\
1
\end{array}\right) \cdot d^{p} \cdot S_{1}(a, d)+\ldots+ \\
& +\left(\begin{array}{c}
p+1 \\
p-2
\end{array}\right) \cdot d^{3} \cdot S_{p-2}(a, d)+\left(\begin{array}{c}
p+1 \\
p-1
\end{array}\right) \cdot d^{2} \cdot S_{p-1}(a, d)+\left(\begin{array}{c}
p+1 \\
p
\end{array}\right) \cdot d \cdot S_{p}(a, d) .
\end{aligned}
$$

Mivel $\left(\begin{array}{c}p+1 \\ p\end{array}\right)=p+1$, átrendezés után a következő egyenlőséghez jutunk:

$$
\begin{aligned}
& (p+1) \cdot d \cdot S_{p}(a, d)=(a+n d)^{p+1}-a^{p+1}-\left(\begin{array}{c}
p+1 \\
p-1
\end{array}\right) \cdot d^{2} \cdot S_{p-1}(a, d)- \\
& -\left(\begin{array}{c}
p+1 \\
p-2
\end{array}\right) \cdot d^{3} \cdot S_{p-2}(a, d)-\ldots-\left(\begin{array}{c}
p+1 \\
1
\end{array}\right) \cdot d^{p} \cdot S_{1}(a, d)-\left(\begin{array}{c}
p+1 \\
0
\end{array}\right) \cdot d^{p+1} \cdot S_{0}(a, d) .
\end{aligned}
$$

Felhasználva, hogy $\left(\begin{array}{c}p+1 \\ i\end{array}\right)=\left(\begin{array}{c}p+1 \\ p+1-i\end{array}\right)$, ahol $i=0,1, \ldots, p-1$, ennek következtében a (3.5.9) összefüggés átírható az alábbi alakra is:

$$
\begin{aligned}
& (p+1) \cdot d \cdot S_{p}(a, d)=(a+n d)^{p+1}-a^{p+1}-\left(\begin{array}{c}
p+1 \\
2
\end{array}\right) \cdot d^{2} \cdot S_{p-1}(a, d)- \\
& -\left(\begin{array}{c}
p+1 \\
3
\end{array}\right) \cdot d^{3} \cdot S_{p-2}(a, d)-\ldots-\left(\begin{array}{c}
p+1 \\
p
\end{array}\right) \cdot d^{p} \cdot S_{1}(a, d)-\left(\begin{array}{c}
p+1 \\
p+1
\end{array}\right) \cdot d^{p+1} \cdot S_{0}(a, d),
\end{aligned}
$$

ami pontosan a 3.3.3. fejezet (3.3.3) összefüggése.

\subsubsection{A differenciálszámítást felhasználó módszer alkalmazása az alternáló összeg esetére}

Mind az elsőként leírt módszer esetén a 3.1.3. fejezetben, mind pedig a harmadikként tárgyalt módszernél a 3.3.5. fejezetben már volt szó az első $n$ pozitív egész szám $p$-edik hatványa váltakozó előjelü összegének kiszámításáról, vagyis az

$$
S_{p}^{*}=1^{p}-2^{p}+3^{p}-4^{p}+\ldots+(-1)^{n-1} \cdot n^{p}=\sum_{k=1}^{n}(-1)^{k-1} \cdot k^{p}
$$

összeg meghatározásáról. Ezekben a fejezetekben már bemutattunk olyan módszereket, melyek segítségével az alternáló összegek kiszámításához szükséges rekurziókat fel tudjuk írni.

A továbbiakban egy újabb módszert mutatunk be az $S_{p}^{*}$ kiszámítására, $\mathrm{s}$ ennek gondolatmenete is hasonlít - a 3.5.1. fejezetben már ismertetett -, az $S_{p}$ kiszámításánál 
bemutatottra. Itt is egy rekurziós összefüggést állítunk fel, ezúttal is csak az $S_{p}^{*}$ kifejezések között, tehát az eredményekhez ismételten nincs szükségünk az $S_{p}$ sorozat tagjaira.

Legyen adott a következö függvény: $F_{n}: R \rightarrow R, F_{n}(x)=\sum_{l=1}^{n}(-1)^{l-1} \cdot e^{l \cdot x}$, ahol $n \in Z^{+}$.

Ekkor $\left(e^{2 \cdot x}-1\right) \cdot F_{n}(x)=\left(e^{2 \cdot x}-1\right) \cdot \sum_{l=1}^{n}(-1)^{l-1} \cdot e^{l \cdot x}=\sum_{l=1}^{n}\left[(-1)^{l-1} \cdot e^{(l+2) \cdot x}-(-1)^{l-1} \cdot e^{l \cdot x}\right]$.

A $\sum_{l=1}^{n}\left[(-1)^{l-1} \cdot e^{(l+2) \cdot x}-(-1)^{l-1} \cdot e^{l \cdot x}\right]$ egy teleszkópikus összeg, amely az összevonások után $(-1)^{n-1} \cdot e^{(n+2) \cdot x}+(-1)^{n-2} \cdot e^{(n+1) \cdot x}+e^{2 \cdot x}-e^{x}$ lesz és így

$$
\left(e^{2 \cdot x}-1\right) \cdot F_{n}(x)=-e^{x}+e^{2 \cdot x}+(-1)^{n-2} \cdot e^{(n+1) \cdot x}+(-1)^{n-1} \cdot e^{(n+2) \cdot x},
$$

minden $n$ pozitív egész szám esetén.

Ha a (3.5.10) összefüggés mindkét oldalán szereplő függvényeknek vesszük a $(p+1)$-edrendủ deriváltját, ahol $p \in N$, akkor a (3.5.1) figyelembe vételével

$$
\begin{aligned}
& -e^{x}+2^{p+1} \cdot e^{2 \cdot x}+(-1)^{n-2} \cdot(n+1)^{p+1} \cdot e^{(n+1) \cdot x}+(-1)^{n-1} \cdot(n+2)^{p+1} \cdot e^{(n+2) \cdot x}= \\
& =\sum_{i=0}^{p+1}\left(\begin{array}{c}
p+1 \\
i
\end{array}\right) \cdot\left(e^{2 \cdot x}-1\right)^{(p+1-i)} \cdot\left[F_{n}(x)\right]^{(i)} .
\end{aligned}
$$

Egyfelől $\left(e^{2 \cdot x}-1\right)^{(p+1-i)}=2^{p+1-i} \cdot e^{2 \cdot x}$, ha $\quad p+1-i \geq 1 \quad-\quad$ azaz $\quad 0 \leq i \leq p \quad-\quad$ és $\left(e^{2 \cdot x}-1\right)^{(p+1-i)}=e^{2 \cdot x}-1$, ha $i=p+1$, másrészt pedig

$\left[F_{n}(x)\right]^{(i)}=\left[e^{x}-e^{2 \cdot x}+e^{3 \cdot x}-e^{4 \cdot x}+\ldots+(-1)^{n-1} \cdot e^{n \cdot x}\right]^{(i)}=$

$=e^{x}-2^{i} \cdot e^{2 \cdot x}+3^{i} \cdot e^{3 \cdot x}-4^{i} \cdot e^{4 \cdot x}+\ldots+(-1)^{n-1} \cdot n^{i} \cdot e^{n \cdot x}=\sum_{k=1}^{n}(-1)^{k-1} \cdot k^{i} \cdot e^{k \cdot x}$.

Mindezekre tekintettel és azt is figyelembe véve, hogy $\left(\begin{array}{c}p+1 \\ p+1\end{array}\right)=1$, a (3.5.11) összefüggés átalakul és adódik hogy

$$
\begin{aligned}
& -e^{x}+2^{p+1} \cdot e^{2 \cdot x}+(-1)^{n-2} \cdot(n+1)^{p+1} \cdot e^{(n+1) \cdot x}+(-1)^{n-1} \cdot(n+2)^{p+1} \cdot e^{(n+2) \cdot x}= \\
& =\sum_{i=0}^{p+1}\left[\left(\begin{array}{c}
p+1 \\
i
\end{array}\right) \cdot\left(e^{2 \cdot x}-1\right)^{(p+1-i)} \cdot\left(\sum_{k=1}^{n}(-1)^{k-1} \cdot k^{i} \cdot e^{k \cdot x}\right)\right]= \\
& =\sum_{i=0}^{p}\left[\left(\begin{array}{c}
p+1 \\
i
\end{array}\right) \cdot\left(e^{2 \cdot x}-1\right)^{(p+1-i)} \cdot\left(\sum_{k=1}^{n}(-1)^{k-1} \cdot k^{i} \cdot e^{k \cdot x}\right)\right]+\left(\begin{array}{c}
p+1 \\
p+1
\end{array}\right) \cdot\left(e^{2 \cdot x}-1\right) \cdot\left[\sum_{k=1}^{n}(-1)^{k-1} \cdot k^{p+1} \cdot e^{k \cdot x}\right]= \\
& =\sum_{i=0}^{p}\left[\left(\begin{array}{c}
p+1 \\
i
\end{array}\right) \cdot 2^{p+1-i} \cdot e^{2 \cdot x} \cdot\left(\sum_{k=1}^{n}(-1)^{k-1} \cdot k^{i} \cdot e^{k \cdot x}\right)\right]+\left(e^{2 \cdot x}-1\right) \cdot\left[\sum_{k=1}^{n}(-1)^{k-1} \cdot k^{p+1} \cdot e^{k \cdot x}\right]= \\
& =\sum_{i=0}^{p} \sum_{k=1}^{n}\left(\begin{array}{c}
p+1 \\
i
\end{array}\right) \cdot(-1)^{k-1} \cdot 2^{p+1-i} \cdot k^{i} \cdot e^{(k+2) \cdot x}+\left(e^{2 \cdot x}-1\right) \cdot\left[\sum_{k=1}^{n}(-1)^{k-1} \cdot k^{p+1} \cdot e^{k \cdot x}\right] .
\end{aligned}
$$


Tehát felírható, hogy

$$
\begin{aligned}
& -e^{x}+2^{p+1} \cdot e^{2 \cdot x}+(-1)^{n-2} \cdot(n+1)^{p+1} \cdot e^{(n+1) \cdot x}+(-1)^{n-1} \cdot(n+2)^{p+1} \cdot e^{(n+2) \cdot x}= \\
& =\sum_{i=0}^{p} \sum_{k=1}^{n}\left(\begin{array}{c}
p+1 \\
i
\end{array}\right) \cdot(-1)^{k-1} \cdot 2^{p+1-i} \cdot k^{i} \cdot e^{(k+2) \cdot x}+\left(e^{2 \cdot x}-1\right) \cdot\left[\sum_{k=1}^{n}(-1)^{k-1} \cdot k^{p+1} \cdot e^{k \cdot x}\right] .
\end{aligned}
$$

Ha a (3.5.12) összefüggésben az $x$ helyébe 0 -t írunk és felhasználva, hogy $e^{0}=1$ kapjuk hogy

$$
\begin{aligned}
& -1+2^{p+1} \cdot 1+(-1)^{n-2} \cdot(n+1)^{p+1} \cdot 1+(-1)^{n-1} \cdot(n+2)^{p+1} \cdot 1= \\
& =\sum_{i=0}^{p} \sum_{k=1}^{n}\left(\begin{array}{c}
p+1 \\
i
\end{array}\right) \cdot(-1)^{k-1} \cdot 2^{p+1-i} \cdot k^{i} \cdot 1+(1-1) \cdot\left[\sum_{k=1}^{n}(-1)^{k-1} \cdot k^{p+1} \cdot 1\right] \\
& -1+2^{p+1}+(-1)^{n-2} \cdot(n+1)^{p+1}+(-1)^{n-1} \cdot(n+2)^{p+1}=\sum_{i=0}^{p} \sum_{k=1}^{n}\left(\begin{array}{c}
p+1 \\
i
\end{array}\right) \cdot(-1)^{k-1} \cdot 2^{p+1-i} \cdot k^{i}= \\
& =\sum_{i=0}^{p}\left[\sum_{k=1}^{n}(-1)^{k-1} \cdot k^{i}\right] \cdot\left(\begin{array}{c}
p+1 \\
i
\end{array}\right) \cdot 2^{p+1-i}=\sum_{i=0}^{p} S_{i}^{*} \cdot\left(\begin{array}{c}
p+1 \\
i
\end{array}\right) \cdot 2^{p+1-i},
\end{aligned}
$$

azaz

$$
\begin{aligned}
& -1+2^{p+1}-(-1)^{n-1} \cdot(n+1)^{p+1}+(-1)^{n-1} \cdot(n+2)^{p+1}= \\
& =\left(\begin{array}{c}
p+1 \\
0
\end{array}\right) \cdot 2^{p+1} \cdot S_{0}^{*}+\left(\begin{array}{c}
p+1 \\
1
\end{array}\right) \cdot 2^{p} \cdot S_{1}^{*}+\ldots+\left(\begin{array}{c}
p+1 \\
p-1
\end{array}\right) \cdot 2^{2} \cdot S_{p-1}^{*}+\left(\begin{array}{c}
p+1 \\
p
\end{array}\right) \cdot 2 \cdot S_{p}^{*} .
\end{aligned}
$$

Mivel $\left(\begin{array}{c}p+1 \\ 0\end{array}\right)=1$ és $S_{0}^{*}=\frac{1+(-1)^{n-1}}{2}$, így

$\left(\begin{array}{c}p+1 \\ 0\end{array}\right) \cdot 2^{p+1} \cdot S_{0}^{*}=2^{p+1} \cdot \frac{1+(-1)^{n-1}}{2}=2^{p}+(-1)^{n-1} \cdot 2^{p}$.

Fentieket felhasználva és figyelembe véve, hogy $\left(\begin{array}{c}p+1 \\ p\end{array}\right)=p+1$, a (3.5.13) összefüggés átrendezés után átírható az alábbi alakra:

$2 \cdot(p+1) \cdot S_{p}^{*}=$

$$
=-1+2^{p+1}+(-1)^{n-1} \cdot\left[(n+2)^{p+1}-(n+1)^{p+1}\right]-2^{p}-(-1)^{n-1} \cdot 2^{p}-\sum_{i=1}^{p-1}\left(\begin{array}{c}
p+1 \\
i
\end{array}\right) \cdot 2^{p+1-i} \cdot S_{i}^{*},
$$

mely összefüggés az összevonások után és felhasználva, hogy

$$
\sum_{i=1}^{p-1}\left(\begin{array}{c}
p+1 \\
i
\end{array}\right) \cdot 2^{p+1-i} \cdot S_{i}^{*}=\sum_{i=1}^{p-1}\left(\begin{array}{c}
p+1 \\
p-i
\end{array}\right) \cdot 2^{i+1} \cdot S_{p-i}^{*}=\sum_{i=1}^{p-1}\left(\begin{array}{c}
p+1 \\
i+1
\end{array}\right) \cdot S_{p-i}^{*} \cdot 2^{i+1}=\sum_{k=2}^{p}\left(\begin{array}{c}
p+1 \\
k
\end{array}\right) \cdot S_{p+1-k}^{*} \cdot 2^{k}
$$

átalakul és a következő végső - kívánt - alakot ölti:

$$
2 \cdot(p+1) \cdot S_{p}^{*}=(-1)^{n-1} \cdot\left[(n+2)^{p+1}-(n+1)^{p+1}-2^{p}\right]+2^{p}-1-\sum_{k=2}^{p}\left(\begin{array}{c}
p+1 \\
k
\end{array}\right) \cdot S_{p+1-k}^{*} \cdot 2^{k},(3.5 .14)
$$

ami pontosan a 3.3.5. fejezet (3.3.6) összefüggése. 


\subsection{4. Általánosítás a deriválást alkalmazó módszer segítségével a számtani sorozat alternáló összegére}

A következőkben ötvözve a számtani sorozatnál és a váltakozó elöjelű összegzésnél már leírtakat, ebben a fejezetben a korábbi - ide illeszkedő - részeknél megismerthez hasonló gondolatmenettel általánosítunk.

Kiindulásként tekintsünk egy számtani sorozatot, és vizsgáljuk meg, hogy mit tudunk mondani a sorozat első $n$ tagja $p$-edik hatványának váltakozó előjelü összegéről!

Legyen $\left\{a_{n}\right\}_{n \geq 1}$ egy számtani sorozat, amelynek első eleme $a$ és differenciája $d$, ahol $a, d \in R$.

Legyen továbbá $S_{p}^{*}(a, d)=a_{1}^{p}-a_{2}^{p}+a_{3}^{p}-a_{4}^{p}+\ldots+(-1)^{n-1} \cdot a_{n}^{p}=\sum_{k=1}^{n}(-1)^{k-1} \cdot a_{k}^{p}$.

A $p=0$, illetve $d=0$ esetekkel külön nem foglalkozunk, hiszen könnyen belátható, hogy

$$
S_{0}^{*}(a, d)=\frac{1+(-1)^{n-1}}{2}=\left\{\begin{array}{ll}
0, & \text { ha } n \text { páros } \\
1, & \text { ha } n \text { páratlan, }
\end{array} \quad \text { illetve } S_{p}^{*}(a, 0)= \begin{cases}0, & \text { ha } n \text { páros } \\
a^{p}, & \text { ha } n \text { páratlan. }\end{cases}\right.
$$

Tegyük fel tehát, hogy $d \neq 0$. Az előző fejezetekhez hasonlóan ismét keressünk egy megfelelö függvényt, mely segítségével előállíthatjuk a kívánt rekurziós összefüggést.

Legyen adott a következő függvény: $F_{n}: R \rightarrow R, F_{n}(x)=\sum_{l=1}^{n}(-1)^{l-1} \cdot e^{a_{l} \cdot x}$, ahol $n \in Z^{+}$.

Ekkor

$$
\begin{aligned}
& \left(e^{2 d \cdot x}-1\right) \cdot F_{n}(x)=\left(e^{2 d \cdot x}-1\right) \cdot \sum_{l=1}^{n}(-1)^{l-1} \cdot e^{a_{l} \cdot x}=\sum_{l=1}^{n}\left[(-1)^{l-1} \cdot e^{\left(a_{l}+2 d\right) \cdot x}-(-1)^{l-1} \cdot e^{a_{l} \cdot x}\right]= \\
& =\sum_{l=1}^{n}\left[(-1)^{l-1} \cdot e^{a_{l+2} \cdot x}-(-1)^{l-1} \cdot e^{a_{l} \cdot x}\right]=\sum_{l=1}^{n}\left[(-1)^{l-1} \cdot\left(e^{a_{l+2} \cdot x}-e^{a_{l} \cdot x}\right)\right] .
\end{aligned}
$$

A $\sum_{l=1}^{n}\left[(-1)^{l-1} \cdot\left(e^{a_{l+2} \cdot x}-e^{a_{l} \cdot x}\right)\right]$ egy teleszkópikus összeg, amely az összevonások után $-e^{a_{1} \cdot x}+e^{a_{2} \cdot x}+(-1)^{n-2} \cdot e^{a_{n+1} \cdot x}+(-1)^{n-1} \cdot e^{a_{n+2} \cdot x}$ alakra írható és így

$$
\left(e^{2 d \cdot x}-1\right) \cdot F_{n}(x)=-e^{a_{1} \cdot x}+e^{a_{2} \cdot x}+(-1)^{n-1} \cdot\left(e^{a_{n+2} \cdot x}-e^{a_{n+1} \cdot x}\right),
$$

minden $n$ pozitív egész szám esetén.

Ha a (3.5.15) összefüggés mindkét oldalán szereplő függvényeknek vesszük a $(p+1)$-edrendủ deriváltját, ahol $p \in N$, akkor a (3.5.1) figyelembe vételével

$$
\begin{aligned}
& -a_{1}^{p+1} \cdot e^{a_{1} \cdot x}+a_{2}^{p+1} \cdot e^{a_{2} \cdot x}+(-1)^{n-1} \cdot\left(a_{n+2}^{p+1} \cdot e^{a_{n+2} \cdot x}-a_{n+1}^{p+1} \cdot e^{a_{n+1} \cdot x}\right)= \\
& =\sum_{i=0}^{p+1}\left(\begin{array}{c}
p+1 \\
i
\end{array}\right) \cdot\left(e^{2 d \cdot x}-1\right)^{(p+1-i)} \cdot\left[F_{n}(x)\right]^{(i)} .
\end{aligned}
$$

Egyfelől $\left(e^{2 d \cdot x}-1\right)^{(p+1-i)}=(2 d)^{p+1-i} \cdot e^{2 d \cdot x}$, ha $\quad p+1-i \geq 1 \quad-\quad$ azaz $0 \leq i \leq p \quad-$ és $\left(e^{2 d \cdot x}-1\right)^{(p+1-i)}=e^{2 d \cdot x}-1$, ha $i=p+1$, másrészt pedig

$\left[F_{n}(x)\right]^{(i)}=\left[e^{a_{1} \cdot x}-e^{a_{2} \cdot x}+e^{a_{3} \cdot x}-e^{a_{4} \cdot x}+\ldots+(-1)^{n-1} \cdot e^{a_{n} \cdot x}\right]^{(i)}=$

$=a_{1}^{i} \cdot e^{a_{1} \cdot x}-a_{2}^{i} \cdot e^{a_{2} \cdot x}+a_{3}^{i} \cdot e^{a_{3} \cdot x}-a_{4}^{i} \cdot e^{a_{4} \cdot x}+\ldots+(-1)^{n-1} \cdot a_{n}^{i} \cdot e^{a_{n} \cdot x}=\sum_{k=1}^{n}(-1)^{k-1} \cdot a_{k}^{i} \cdot e^{a_{k} \cdot x}$. 
Mindezek alapján és felhasználva, hogy $\left(\begin{array}{c}p+1 \\ p+1\end{array}\right)=1$, a (3.5.16) összefüggés átalakul

$-a_{1}^{p+1} \cdot e^{a_{1} \cdot x}+a_{2}^{p+1} \cdot e^{a_{2} \cdot x}+(-1)^{n-1} \cdot\left(a_{n+2}^{p+1} \cdot e^{a_{n+2} \cdot x}-a_{n+1}^{p+1} \cdot e^{a_{n+1} \cdot x}\right)=$

$=\sum_{i=0}^{p+1}\left[\left(\begin{array}{c}p+1 \\ i\end{array}\right) \cdot\left(e^{2 d \cdot x}-1\right)^{(p+1-i)} \cdot\left(\sum_{k=1}^{n}(-1)^{k-1} \cdot a_{k}^{i} \cdot e^{a_{k} \cdot x}\right)\right]=$

$=\sum_{i=0}^{p}\left[\left(\begin{array}{c}p+1 \\ i\end{array}\right) \cdot\left(e^{2 d \cdot x}-1\right)^{(p+1-i)} \cdot\left(\sum_{k=1}^{n}(-1)^{k-1} \cdot a_{k}^{i} \cdot e^{a_{k} \cdot x}\right)\right]+\left(\begin{array}{c}p+1 \\ p+1\end{array}\right) \cdot\left(e^{2 d \cdot x}-1\right) \cdot\left(\sum_{k=1}^{n}(-1)^{k-1} \cdot a_{k}^{p+1} \cdot e^{a_{k} \cdot x}\right)=$

$=\sum_{i=0}^{p}\left[\left(\begin{array}{c}p+1 \\ i\end{array}\right) \cdot(2 d)^{p+1-i} \cdot e^{2 d \cdot x} \cdot\left(\sum_{k=1}^{n}(-1)^{k-1} \cdot a_{k}^{i} \cdot e^{a_{k} \cdot x}\right)\right]+\left(e^{2 d \cdot x}-1\right) \cdot\left(\sum_{k=1}^{n}(-1)^{k-1} \cdot a_{k}^{p+1} \cdot e^{a_{k} \cdot x}\right)=$

$=\sum_{i=0}^{p} \sum_{k=1}^{n}\left(\begin{array}{c}p+1 \\ i\end{array}\right) \cdot(2 d)^{p+1-i} \cdot(-1)^{k-1} \cdot a_{k}^{i} \cdot e^{a_{k} \cdot x} \cdot e^{2 d \cdot x}+\left(e^{2 d \cdot x}-1\right) \cdot\left(\sum_{k=1}^{n}(-1)^{k-1} \cdot a_{k}^{p+1} \cdot e^{a_{k} \cdot x}\right)$.

Tehát:

$$
\begin{aligned}
& -a_{1}^{p+1} \cdot e^{a_{1} \cdot x}+a_{2}^{p+1} \cdot e^{a_{2} \cdot x}+(-1)^{n-1} \cdot\left(a_{n+2}^{p+1} \cdot e^{a_{n+2} \cdot x}-a_{n+1}^{p+1} \cdot e^{a_{n+1} \cdot x}\right)= \\
& =\sum_{i=0}^{p} \sum_{k=1}^{n}\left(\begin{array}{c}
p+1 \\
i
\end{array}\right) \cdot(2 d)^{p+1-i} \cdot(-1)^{k-1} \cdot a_{k}^{i} \cdot e^{\left(a_{k}+2 d\right) \cdot x}+\left(e^{2 d \cdot x}-1\right) \cdot\left(\sum_{k=1}^{n}(-1)^{k-1} \cdot a_{k}^{p+1} \cdot e^{a_{k} \cdot x}\right)
\end{aligned}
$$

Ha a (3.5.17) összefüggésben az $x$ helyébe 0 -t írunk és felhasználva, hogy $e^{0}=1$ kapjuk hogy

$$
\begin{aligned}
& -a_{1}^{p+1} \cdot 1+a_{2}^{p+1} \cdot 1+(-1)^{n-1} \cdot\left(a_{n+2}^{p+1} \cdot 1-a_{n+1}^{p+1} \cdot 1\right)= \\
& =\sum_{i=0}^{p} \sum_{k=1}^{n}\left(\begin{array}{c}
p+1 \\
i
\end{array}\right) \cdot(2 d)^{p+1-i} \cdot(-1)^{k-1} \cdot a_{k}^{i} \cdot 1+(1-1) \cdot\left(\sum_{k=1}^{n}(-1)^{k-1} \cdot a_{k}^{p+1} \cdot 1\right) . \\
& -a_{1}^{p+1}+a_{2}^{p+1}+(-1)^{n-1} \cdot\left(a_{n+2}^{p+1}-a_{n+1}^{p+1}\right)=\sum_{i=0}^{p} \sum_{k=1}^{n}\left(\begin{array}{c}
p+1 \\
i
\end{array}\right) \cdot(2 d)^{p+1-i} \cdot(-1)^{k-1} \cdot a_{k}^{i}= \\
& =\sum_{i=0}^{p}\left[\left(\sum_{k=1}^{n}(-1)^{k-1} \cdot a_{k}^{i}\right) \cdot\left(\begin{array}{c}
p+1 \\
i
\end{array}\right) \cdot(2 d)^{p+1-i}\right]=\sum_{i=0}^{p}\left[S_{i}^{*}(a, d) \cdot\left(\begin{array}{c}
p+1 \\
i
\end{array}\right) \cdot(2 d)^{p+1-i}\right],
\end{aligned}
$$

azaz

$$
\begin{aligned}
& -a_{1}^{p+1}+a_{2}^{p+1}+(-1)^{n-1} \cdot\left(a_{n+2}^{p+1}-a_{n+1}^{p+1}\right)=\left(\begin{array}{c}
p+1 \\
0
\end{array}\right) \cdot(2 d)^{p+1} \cdot S_{0}^{*}(a, d)+ \\
& +\left(\begin{array}{c}
p+1 \\
1
\end{array}\right) \cdot(2 d)^{p} \cdot S_{1}^{*}(a, d)+\ldots+\left(\begin{array}{c}
p+1 \\
p-1
\end{array}\right) \cdot(2 d)^{2} \cdot S_{p-1}^{*}(a, d)+\left(\begin{array}{c}
p+1 \\
p
\end{array}\right) \cdot(2 d) \cdot S_{p}^{*}(a, d) .
\end{aligned}
$$

Mivel $\left(\begin{array}{c}p+1 \\ 0\end{array}\right)=1$ és $S_{0}^{*}(a, d)=S_{0}^{*}=\frac{1+(-1)^{n-1}}{2}$, így

$\left(\begin{array}{c}p+1 \\ 0\end{array}\right) \cdot(2 d)^{p+1} \cdot S_{0}^{*}(a, d)=(2 d)^{p+1} \cdot \frac{1+(-1)^{n-1}}{2}=2^{p} \cdot d^{p+1}+(-1)^{n-1} \cdot 2^{p} \cdot d^{p+1}$. 
Mindezek felhasználásával és azt is figyelembe véve, hogy $\left(\begin{array}{c}p+1 \\ p\end{array}\right)=p+1$, a

összefüggés átrendezés után átírható az alábbi alakra:

$$
\begin{aligned}
& 2 d \cdot(p+1) \cdot S_{p}^{*}(a, d)=-a_{1}^{p+1}+a_{2}^{p+1}+(-1)^{n-1} \cdot\left(a_{n+2}^{p+1}-a_{n+1}^{p+1}\right)-2^{p} \cdot d^{p+1}- \\
& -(-1)^{n-1} \cdot 2^{p} \cdot d^{p+1}-\sum_{i=1}^{p-1}\left[\left(\begin{array}{c}
p+1 \\
i
\end{array}\right) \cdot(2 d)^{p+1-i} \cdot S_{i}^{*}(a, d)\right] .
\end{aligned}
$$

Ez az összefüggés az összevonások után és felhasználva, hogy

$$
\begin{aligned}
& \sum_{i=1}^{p-1}\left(\begin{array}{c}
p+1 \\
i
\end{array}\right) \cdot(2 d)^{p+1-i} \cdot S_{i}^{*}(a, d)=\sum_{i=1}^{p-1}\left(\begin{array}{c}
p+1 \\
p-i
\end{array}\right) \cdot(2 d)^{i+1} \cdot S_{p-i}^{*}(a, d)= \\
& =\sum_{i=1}^{p-1}\left(\begin{array}{c}
p+1 \\
i+1
\end{array}\right) \cdot S_{p-i}^{*}(a, d) \cdot(2 d)^{i+1}=\sum_{k=2}^{p}\left(\begin{array}{c}
p+1 \\
k
\end{array}\right) \cdot S_{p+1-k}^{*}(a, d) \cdot(2 d)^{k},
\end{aligned}
$$

átalakul a következő szerint:

$$
\begin{aligned}
& 2 d \cdot(p+1) \cdot S_{p}^{*}(a, d)= \\
& =(-1)^{n-1} \cdot\left[a_{n+2}^{p+1}-a_{n+1}^{p+1}-d \cdot(2 d)^{p}\right]+a_{2}^{p+1}-a_{1}^{p+1}-d \cdot(2 d)^{p}-\sum_{k=2}^{p}\left(\begin{array}{c}
p+1 \\
k
\end{array}\right) \cdot S_{p+1-k}^{*}(a, d) \cdot(2 d)^{k},
\end{aligned}
$$

ami pontosan a 3.3.7. fejezet (3.3.7) összefüggése.

Ennek a fejezetnek lényege abban foglalható össze, hogy egy speciális függvény és a differenciálszámítás felhasználásával előállítunk egy olyan összefüggést, amelyben a változó helyére 0-t írva, viszonylag egyszerü és rövid számolással a kívánt rekurziós formulához jutunk. A módszer hasznosságát, szélesebb körü alkalmazhatóságát mutatja, hogy általánosítható az alternáló összegre is, valamint a számtani sorozatok normál és alternáló összegére is.

Végezetül a disszertáció rekurziókkal foglalkozó része az alábbi általános gondolatokkal zárható:

1. a hatványösszegzés problematikájának megoldására jól használható metodikának bizonyulnak a rekurzióra vezető módszerek,

2. rekurziós összefüggések a gondolkodás sokféle útján, számos, egymástól nagyon eltérő matematikai tudásanyag felhasználásával nyerhetők,

3. a rekurziós módszerek egy része jól általánosítható a számtani sorozatokra, ezek alternáló összegére, valamint a hatványösszegek között fennálló további összefüggések előállítására is. 


\section{Nem rekurziós módszerek}

Számos olyan matematikai feladat létezik, amely megoldható mind rekurziós formulákkal, mind pedig azok nélkül. A nem rekurzióra vezető módszertani eljárások alkalmazása azért is nagyon fontos a matematikában, mert ezek segítségével azonnal „kész” eredményekhez jutunk. Ezeknek a módszereknek pontosan az a legnagyobb előnye a rekurziókhoz képest, hogy itt nem kell megelőző tagok - gyakran hosszadalmas - kiszámításával „,vesződni”, a kapott eredmény egyből megadja a probléma végleges megoldását.

A hatványösszegek kiszámításának problematikája - mint alább látható lesz majd szerencsére olyan természetü, hogy a megoldásban nem rekurziós módszerek is jól alkalmazhatók. A következőkben két ilyen módszert mutatunk be.

\section{1. Összefüggés levezetése a differenciasorozatok segítségével}

Hatványösszegek kiszámítására alkalmas összefüggés felírható az ún. differenciasorozatok felhasználásával is. Az alább bemutatásra kerülő módszer részleteiben a kombinatorikai alapfogalmak, a számtani sorozatok és a differenciasorozatok fontosabb tulajdonságainak ismeretét igényli.

$\mathrm{Az}$ ismertetendő metodika gondolatmenete a következő: először megismerkedünk a differenciasorozat fogalmával, majd annak néhány tulajdonságával, ezután bemutatjuk egy tetszőleges $p$-edrendű számtani sorozat általános tagjának felírását a hozzárendelt differenciasorozat segítségével (lásd [12] 82-87. o.). Végül egy olyan (nem rekurziós) összefüggést adunk meg, melynek segítségével kiszámolható egy tetszőleges $p$-edrendü számtani sorozat első $n$ tagjának összege az egymás után következő differenciasorozatok kezdő tagjainak segítségével.

\subsubsection{Bevezetés a differenciasorozatok vizsgálatába}

Legyen adott az $\left\{a_{n}\right\}_{n \geq 1}$ valós számsorozat. Képezzük azt a sorozatot, amely a szomszédos tagok $a_{i+1}-a_{i}$ szerint számított különbségeiből áll, azaz állítsuk elő az

$$
a_{2}-a_{1}=\Delta a_{1} ; a_{3}-a_{2}=\Delta a_{2} ; \ldots ; a_{k+1}-a_{k}=\Delta a_{k} ; \ldots
$$

speciális sorozatot.

Ha a kapott számsorozat mindegyik tagja ugyanazzal a nullától különböző valós számmal egyenlő, akkor az $\left\{a_{n}\right\}_{n \geq 1}$ sorozatot elsőrendü számtani sorozatnak nevezzük (ha a (4.1.1) által képzett sorozat minden tagja nulla, vagyis az $\left\{a_{n}\right\}_{n \geq 1}$ sorozat tagjai egyenlőek egymással, akkor O-adrendü számtani sorozatról beszélünk).

Nevezzük el a (4.1.1) szerint előálló sorozatot, az adott $\left\{a_{n}\right\}_{n \geq 1}$ sorozat első differenciasorozatának. Hasonló elgondolással képezhetjük a (4.1.1) sorozat differenciasorozatát is, melynek tagjai 


$$
\Delta a_{2}-\Delta a_{1}=\Delta\left(\Delta a_{1}\right)=\Delta^{2} a_{1} ; \Delta a_{3}-\Delta a_{2}=\Delta^{2} a_{2} ; \ldots ; \Delta a_{k+1}-\Delta a_{k}=\Delta^{2} a_{k} ; \ldots
$$

Az így kapott (4.1.2) sorozat az $\left\{a_{n}\right\}_{n \geq 1}$ sorozat második differenciasorozata.

Hasonlóan értelmezhetjük a harmadik, negyedik stb. differenciasorozatot is azzal a megállapodással, hogy ha már a $(p-1)$-edik differenciasorozat értelmezve van, akkor ennek első differenciasorozatát nevezzük az eredeti sorozat $p$-edik differenciasorozatának.

Példaként tekintsük a pozitív egész számok négyzeteinek sorozatát:

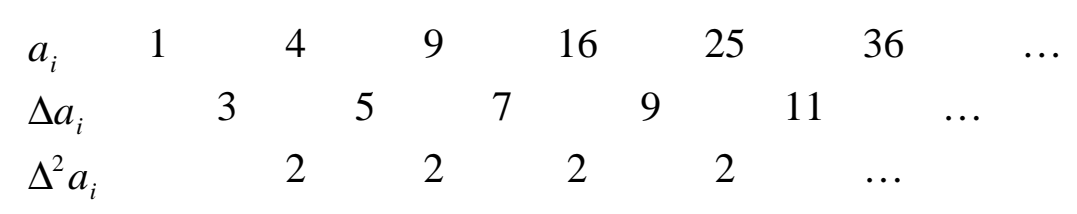

Észrevehető, hogy itt a második differenciasorozat már állandó és így a harmadik (valamint minden magasabb rendü) differenciasorozat mindegyik tagja nulla.

A felírt sorozatra könnyen bebizonyítható ez az adott jelenség, hiszen ebben az esetben az adott sorozat $k$-adik tagja $k^{2}$, ezáltal az első differenciasorozat $k$-adik tagja $(k+1)^{2}-k^{2}=2 k+1$, a második differenciasorozat $k$-adik tagja pedig $2(k+1)+1-(2 k+1)=2$, bármely $k \in Z^{+}$esetén.

\section{$\underline{\text { 1. Definíció }}$}

Az olyan számsorozatot, amely p-edik differenciasorozatának minden tagja ugyanazzal a zérótól különböző számmal egyenlő, p-edrendü számtani sorozatnak nevezzük.

\section{Megjegyzés}

Fenti példánk szerint a négyzetszámok sorozata másodrendủ számtani sorozat, mert a második differenciasorozat minden tagja 2.

A példában leírt gondolatmenettel teljesen analóg módon belátható, hogy minden olyan sorozat, amelynek $k$-adik tagja $k$-nak egy

$$
f(k)=c_{p} k^{p}+c_{p-1} k^{p-1}+\ldots+c_{2} k^{2}+c_{1} k+c_{0}, c_{i} \in R
$$

p-edfokú polinomjával adott, azzal a tulajdonsággal rendelkezik, hogy a sorozat $p$-edik differenciasorozata állandó - ezért a $p$-nél magasabb rendủ differenciasorozatok mindegyik tagja 0 lesz - azaz az a számsorozat, amelynek $k$-adik tagja a (4.1.3) összefüggéssel van megadva, egy $p$-edrendü számtani sorozat (feltéve, ha $c_{p} \neq 0$ ).

Hasonló módon az is kijelenthető, hogy ha $P(x)$ egy $p$-edfokú polinom és az $a_{1}, a_{2}, \ldots, a_{n}, \ldots$ egy olyan számtani sorozat, melynek differenciája $d$, akkor a $P\left(a_{1}\right), P\left(a_{2}\right), \ldots, P\left(a_{n}\right), \ldots$ sorozat $p$-edik differenciasorozata állandó és ennek az állandónak az értéke $p ! d^{p} \cdot A_{p}$, ahol $A_{p}$ az $x^{p}$ együtthatója a $P(x)$ polinomban.

A továbbiakban bebizonyítunk egy tételt, amely egy p-edrendủ számtani sorozat általános tagjára vonatkozik. 


\section{Tétel}

Bármely $p$-edrendủ számtani sorozat $k$-adik tagja $k$-nak egy $p$-edfokú polinomjával adható meg.

\section{Bizonyítás:}

Az adott állítást úgy fogjuk bizonyítani, hogy kiszámítjuk egy tetszőleges $p$-edrendủ számtani sorozat $k$-adik tagját.

Belátható, hogy a $p$-edrendủ számtani sorozat egyértelműen meghatározott az

$$
a_{1} ; \Delta a_{1} ; \Delta^{2} a_{1} ; \ldots ; \Delta^{p} a_{1} ;
$$

számokkal. E számok ismerete annyit jelent, hogy elrendezésük mindegyik sorának kezdő tagja egy adott szám. Az utolsó sort azonnal felírhatjuk, hiszen ennek minden tagja megegyezik a kezdő taggal. Az utolsó előtti sor második tagját megkapjuk, ha összeadjuk az ugyanabban a sorban és az alatta lévő sorban tőle közvetlenül balra álló - már ismert - két számot. Ugyanígy kaphatjuk meg a az utolsó elötti sor többi tagját is, majd ha már ezeket megkaptuk, akkor a felette álló sor tagjait stb.

Lássuk most számításokkal is a tetszőleges $a_{1}, a_{2}, \ldots, a_{k}, \ldots$ p-edrendü számtani sorozat ezen felírását a (4.1.4) által adott számokkal!

A magasabbrendủ számtani sorozat értelmezéséből következik, hogy az első sorban az adott $a_{1}, a_{2}, \ldots, a_{k}, \ldots p$-edrendü, a másodikban a $\Delta a_{1}, \Delta a_{2}, \ldots, \Delta a_{k}, \ldots(p-1)$-edrendü, és így tovább, a $(p-l+1)$-edik sorban pedig a $\Delta^{p-l} a_{1}, \Delta^{p-l} a_{2}, \ldots, \Delta^{p-l} a_{k}, \ldots$ l-edrendü számtani sorozat áll, ahol $l=0,1, \ldots, p$. Azért, hogy megállapításunk az $l=p$ esetben formailag is érvényes maradjon, az első sort $\Delta^{0} a_{1}, \Delta^{0} a_{2}, \ldots, \Delta^{0} a_{k}, \ldots$ alakban írjuk fel (hiszen az adott sorozatot tekinthetjük önmaga 0 -adik differenciasorozataként is).

$\mathrm{Az}(p+1)$-edik sorban álló 0 -adrendű számtani sorozat minden tagja egyenlő az első taggal.

Állapodjunk meg abban, hogy $0 \leq u<v$ esetén $\left(\begin{array}{l}u \\ v\end{array}\right)=0$ legyen. Így a p-edik sorban álló elsőrendű számtani sorozat $k$-adik tagja

$$
\Delta^{p-1} a_{k}=\Delta^{p-1} a_{1}+(k-1) \cdot \Delta^{p} a_{1}=\left(\begin{array}{c}
k-1 \\
0
\end{array}\right) \cdot \Delta^{p-1} a_{1}+\left(\begin{array}{c}
k-1 \\
1
\end{array}\right) \cdot \Delta^{p} a_{1},
$$

ahol $k=1,2, \ldots$ (a (4.1.5) alatti képlet helyes eredményt ad, ha $k=1$ és minden további tagot e sorozatban úgy kapunk meg az előző tagból, hogy hozzáadunk $\Delta^{p} a_{1}$-et).

Az a sejtésünk, hogy a $(p-l+1)$-edik sorban álló $l$-edrendủ számtani sorozat $k$-adik tagja

$$
\Delta^{p-l} a_{k}=\left(\begin{array}{c}
k-1 \\
0
\end{array}\right) \cdot \Delta^{p-l} a_{1}+\left(\begin{array}{c}
k-1 \\
1
\end{array}\right) \cdot \Delta^{p-l+1} a_{1}+\ldots+\left(\begin{array}{c}
k-1 \\
l
\end{array}\right) \cdot \Delta^{p} a_{1}
$$

képlettel számítható. Mivel ez a képlet az $l=0$ és $l=1$ esetekben (bármely $k$-ra) igaznak bizonyult, ezért a fent felírt ,sejtés” bizonyítását $l$ szerinti teljes indukcióval végezzük.

Tegyük fel, hogy a (4.1.6) rögzített $l$ esetén (bármely $k$-ra) igaz, és vizsgáljuk meg a helyességét $(l+1)$-re, azaz hogy teljesül-e a 


$$
\Delta^{p-l-1} a_{k}=\left(\begin{array}{c}
k-1 \\
0
\end{array}\right) \cdot \Delta^{p-l-1} a_{1}+\left(\begin{array}{c}
k-1 \\
1
\end{array}\right) \cdot \Delta^{p-l} a_{1}+\ldots+\left(\begin{array}{c}
k-1 \\
l+1
\end{array}\right) \cdot \Delta^{p} a_{1}
$$

összefüggés (bármely $k$ esetén).

A (4.1.7) igaz $k=1$ esetén, ezért a (4.1.7) általános igazolására újabb teljes indukciót alkalmazhatunk - ezúttal $k$ szerint - feltételezve, hogy a (4.1.7) $(k-1)$-re már igaznak bizonyult (ahol $k \geq 2$ ), azaz teljesül, hogy

$$
\Delta^{p-l-1} a_{k-1}=\left(\begin{array}{c}
k-2 \\
0
\end{array}\right) \cdot \Delta^{p-l-1} a_{1}+\left(\begin{array}{c}
k-2 \\
1
\end{array}\right) \cdot \Delta^{p-l} a_{1}+\ldots+\left(\begin{array}{c}
k-2 \\
l+1
\end{array}\right) \cdot \Delta^{p} a_{1} .
$$

Mivel a különbségképzés elve szerint $\Delta^{p-l} a_{k-1}=\Delta\left(\Delta^{p-l-1} a_{k-1}\right)=\Delta^{p-l-1} a_{k}-\Delta^{p-l-1} a_{k-1}$, innen $\Delta^{p-l-1} a_{k}=\Delta^{p-l-1} a_{k-1}+\Delta^{p-l} a_{k-1}$, ahol a jobboldalon szereplő mindkét tagot az indukciós feltevés értelmében már helyes képlet adja. A jobboldali első tag értékét a (4.1.8)-ból, míg a második tagét a (4.1.6)-ból kaphatjuk meg, ez utóbbit úgy, hogy a $k$ helyébe $(k-1)$-et helyettesítünk. Mindezek alapján

$$
\begin{aligned}
& \Delta^{p-l-1} a_{k}=\Delta^{p-l-1} a_{k-1}+\Delta^{p-l} a_{k-1}=\left(\begin{array}{c}
k-2 \\
0
\end{array}\right) \cdot \Delta^{p-l-1} a_{1}+\left(\begin{array}{c}
k-2 \\
1
\end{array}\right) \cdot \Delta^{p-l} a_{1}+\left(\begin{array}{c}
k-2 \\
2
\end{array}\right) \cdot \Delta^{p-l+1} a_{1}+\ldots+ \\
& +\left(\begin{array}{c}
k-2 \\
l+1
\end{array}\right) \cdot \Delta^{p} a_{1}+\left(\begin{array}{c}
k-2 \\
0
\end{array}\right) \cdot \Delta^{p-l} a_{1}+\left(\begin{array}{c}
k-2 \\
1
\end{array}\right) \cdot \Delta^{p-l+1} a_{1}+\left(\begin{array}{c}
k-2 \\
2
\end{array}\right) \cdot \Delta^{p-l+2} a_{1}+\ldots+\left(\begin{array}{c}
k-2 \\
l
\end{array}\right) \cdot \Delta^{p} a_{1}= \\
& =\left(\begin{array}{c}
k-2 \\
0
\end{array}\right) \cdot \Delta^{p-l-1} a_{1}+\left[\left(\begin{array}{c}
k-2 \\
1
\end{array}\right)+\left(\begin{array}{c}
k-2 \\
0
\end{array}\right)\right] \cdot \Delta^{p-l} a_{1}+\left[\left(\begin{array}{c}
k-2 \\
2
\end{array}\right)+\left(\begin{array}{c}
k-2 \\
1
\end{array}\right)\right] \cdot \Delta^{p-l+1} a_{1}+\ldots+ \\
& \left.+\left(\begin{array}{c}
k-2 \\
l+1
\end{array}\right)+\left(\begin{array}{c}
k-2 \\
l
\end{array}\right)\right] \cdot \Delta^{p} a_{1}= \\
& =\left(\begin{array}{c}
k-1 \\
0
\end{array}\right) \cdot \Delta^{p-l-1} a_{1}+\left(\begin{array}{c}
k-1 \\
1
\end{array}\right) \cdot \Delta^{p-l} a_{1}+\left(\begin{array}{c}
k-1 \\
2
\end{array}\right) \cdot \Delta^{p-l+1} a_{1}+\ldots+\left(\begin{array}{c}
k-1 \\
l+1
\end{array}\right) \cdot \Delta^{p} a_{1},
\end{aligned}
$$

ahol felhasználtuk, hogy $\left(\begin{array}{c}k-2 \\ 0\end{array}\right)=\left(\begin{array}{c}k-1 \\ 0\end{array}\right)$, illetve hogy $\left(\begin{array}{c}u \\ v+1\end{array}\right)+\left(\begin{array}{l}u \\ v\end{array}\right)=\left(\begin{array}{l}u+1 \\ v+1\end{array}\right)$.

Ez éppen azt jelenti, hogy $(k-1)$-ről $k$-ra a (4.1.7) helyessége következik, azaz a (4.1.7) összefüggés bármely $k$ esetén igaz. Ezzel egyidőben pedig befejeztük a (4.1.6) összefüggés bizonyítását is bármely $l$ értékre, mivel azt kaptuk, hogy a (4.1.6)-ból következik a (4.1.7), vagyis a (4.1.6) helyessége is teljesül $(l+1)$-re.

Ha a (4.1.6) összefüggésben az $l$ helyébe $p$-t írunk, akkor azt kapjuk, hogy

$$
\Delta^{0} a_{k}=\left(\begin{array}{c}
k-1 \\
0
\end{array}\right) \cdot \Delta^{0} a_{1}+\left(\begin{array}{c}
k-1 \\
1
\end{array}\right) \cdot \Delta^{1} a_{1}+\left(\begin{array}{c}
k-1 \\
2
\end{array}\right) \cdot \Delta^{2} a_{1}+\ldots+\left(\begin{array}{c}
k-1 \\
p
\end{array}\right) \cdot \Delta^{p} a_{1},
$$

azaz

$$
a_{k}=\left(\begin{array}{c}
k-1 \\
0
\end{array}\right) \cdot a_{1}+\left(\begin{array}{c}
k-1 \\
1
\end{array}\right) \cdot \Delta a_{1}+\left(\begin{array}{c}
k-1 \\
2
\end{array}\right) \cdot \Delta^{2} a_{1}+\ldots+\left(\begin{array}{c}
k-1 \\
p
\end{array}\right) \cdot \Delta^{p} a_{1} .
$$


Összefoglalva tehát a fent leírtakat: ha ismerjük az egymás után következő differenciasorozatok (4.1.4) által megadott kezdő tagjait, akkor az általuk meghatározott $p$ edrendű számtani sorozat $k$-adik tagját a (4.1.9) összefüggés alapján számíthatjuk ki. Az is belátható, hogy ha a (4.1.4) alatti számokat tetszés szerint írjuk fel, akkor a (4.1.9) alatti összefüggés segítségével előállított számsorozat mindig $p$-edrendü lesz, ha a $\Delta^{p} a_{1} \neq 0$ ( $\Delta^{p} a_{1}=0$ esetén a számtani sorozat rendje kisebb lesz, mint $p$ ).

Ha a (4.1.9) alatti összefüggést átírjuk az

$$
a_{k}=a_{1}+(k-1) \cdot \Delta a_{1}+\frac{(k-1)(k-2)}{2 !} \cdot \Delta^{2} a_{1}+\ldots+\frac{(k-1)(k-2) \ldots(k-p)}{p !} \cdot \Delta^{p} a_{1}
$$

alakra, akkor belátható, hogy a tetszőleges $p$-edrendủ számtani sorozat $a_{k}$ tagját a kijelölt müveletek elvégzése után ténylegesen egy (4.1.3) alatti alakra hozható, $k$-ban $p$-edfokú polinom adja meg.

Q.e.d.

Az itt ismertetett elmélet gyakorlati alkalmazására az alábbiakban közreadunk két példát.

1) Tekintsük azt a másodrendủ számtani sorozatot, ahol $a_{1}=1 ; \Delta a_{1}=3 ; \Delta^{2} a_{1}=2$.

Ekkor

$$
\begin{aligned}
& a_{k}=1+3 \cdot\left(\begin{array}{c}
k-1 \\
1
\end{array}\right)+2 \cdot\left(\begin{array}{c}
k-1 \\
2
\end{array}\right)=1+3(k-1)+2 \cdot \frac{(k-1)(k-2)}{2}= \\
& =1+3 k-3+k^{2}-2 k-k+2=k^{2} .
\end{aligned}
$$

Tehát a másodrendű számtani sorozat épp a pozitív egész számok négyzeteinek sorozata.

\section{Megjegyzés}

Az előbbiek alapján az is belátható, hogy tetszőleges $a_{1}, a_{2}, \ldots, a_{p}$ számok esetén, mindig van olyan legfeljebb $p$-edrendủ számtani sorozat, amelynek első $p$ tagja éppen az adott $p$ szám.

2) Keressük meg azt a legfeljebb harmadrendü számtani sorozatot, amelynek első 4 tagja: $2 ; 3 ;-1 ;-1$.

Az alábbi „táblázat” (véges differenciatábla) segítségével kiszámítjuk a differencia sorozatok kezdő tagjait:

$\begin{array}{ccccccc}2 & & 3 & & -1 & & -1 \\ & 1 & & -4 & & 0 & \\ & & -5 & & 4 & & \end{array}$

Azt kaptuk, hogy $a_{1}=2 ; \Delta a_{1}=1 ; \Delta^{2} a_{1}=-5 ; \Delta^{3} a_{1}=9$. Így a (4.1.9) összefüggés alapján:

$$
\begin{aligned}
& a_{k}=2+1 \cdot\left(\begin{array}{c}
k-1 \\
1
\end{array}\right)-5 \cdot\left(\begin{array}{c}
k-1 \\
2
\end{array}\right)+9 \cdot\left(\begin{array}{c}
k-1 \\
3
\end{array}\right)=2+k-1-5 \cdot \frac{(k-1)(k-2)}{2}+9 \cdot \frac{(k-1)(k-2)(k-3)}{6}= \\
& =k+1-5 \cdot \frac{k^{2}-3 k+2}{2}+3 \cdot \frac{k^{3}-6 k^{2}+11 k-6}{2}=
\end{aligned}
$$




$$
=\frac{2 k+2-5 k^{2}+15 k-10+3 k^{3}-18 k^{2}+33 k-18}{2}=\frac{3}{2} k^{3}-\frac{23}{2} k^{2}+25 k-13 .
$$

Tehát a keresett sorozat $k$-adik tagja: $a_{k}=\frac{3}{2} k^{3}-\frac{23}{2} k^{2}+25 k-13$.

\section{Megjegyzés}

A véges differenciatáblákról, általában a differenciaoperátorról és ezek kapcsolatáról a 3.4.3. fejezetben bemutatott Stirling-számokkal, többet is megtudhatunk a [3]-ból 72-76. o. .

\subsubsection{A módszer segítségével előállítható összefüggés}

A továbbiakban megvizsgáljuk, hogy - hasonló elgondolás alapján - hogyan nyerhető összefüggés a magasabb rendü számtani sorozat első $n$ tagjának összegére.

Jelöljük a (4.1.9) által adott $a_{1}, a_{2}, \ldots, a_{k}, \ldots p$-edrendü számtani sorozat első $n$ tagjának összegét $\sigma_{n ; p}$-vel, azaz legyen $\sigma_{n ; p}=a_{1}+a_{2}+\ldots+a_{n}$, illetve legyen $\sigma_{0 ; p}=0$.

Ekkor $\Delta \sigma_{k-1 ; p}=\sigma_{k ; p}-\sigma_{k-1 ; p}=a_{k}$, ahol $k=1,2, \ldots$, ami azt jelenti, hogy a $\sigma_{0 ; p}, \sigma_{1 ; p}, \sigma_{2 ; p}, \ldots$ sorozat első differencia sorozata éppen a kiindulásul szolgáló $a_{1}, a_{2}, \ldots, a_{k}, \ldots p$-edrendü számtani sorozat. Azt kaptuk, hogy a $\sigma_{0 ; p}, \sigma_{1 ; p}, \sigma_{2 ; p}, \ldots$ sorozat $(p+1)$-edrendü számtani sorozat, amelyhez a következő, a (4.1.4) felírás szerinti meghatározó adatok tartoznak, összesen $(p+2)$ darab:

$$
\sigma_{0 ; p}=0 ; \Delta \sigma_{0 ; p}=a_{1} ; \Delta^{2} \sigma_{0 ; p}=\Delta a_{1} ; \ldots ; \Delta^{p+1} \sigma_{0 ; p}=\Delta^{p} a_{1} .
$$

Ezek segítségével a keresett $\sigma_{0 ; p}, \sigma_{1 ; p}, \sigma_{2 ; p}, \ldots$ sorozat $(n+1)$-edik tagja a (4.1.9) alapján azonnal felírható:

$$
\sigma_{n ; p}=\left(\begin{array}{c}
n \\
0
\end{array}\right) \cdot \sigma_{0 ; p}+\left(\begin{array}{c}
n \\
1
\end{array}\right) \cdot \Delta \sigma_{0 ; p}+\left(\begin{array}{l}
n \\
2
\end{array}\right) \cdot \Delta^{2} \sigma_{0 ; p}+\ldots+\left(\begin{array}{c}
n \\
p+1
\end{array}\right) \cdot \Delta^{p+1} \sigma_{0 ; p},
$$

ahonnan

$$
\sigma_{n ; p}=\left(\begin{array}{l}
n \\
1
\end{array}\right) \cdot a_{1}+\left(\begin{array}{l}
n \\
2
\end{array}\right) \cdot \Delta a_{1}+\left(\begin{array}{l}
n \\
3
\end{array}\right) \cdot \Delta^{2} a_{1}+\ldots+\left(\begin{array}{c}
n \\
p+1
\end{array}\right) \cdot \Delta^{p} a_{1} .
$$

Tehát a (4.1.4) alatti adatokkal meghatározott $p$-edrendủ számtani sorozat első $n$ tagjának összegét a (4.1.11) összefüggés adja meg, azaz ha ismerjük az egymás után következő differenciasorozatok kezdő tagjait, ezek segítségével kiszámíthatjuk a $\sigma_{n ; p}$-t.

Belátható, hogy a $\sigma_{n ; p}$ kiszámításánál nincs szükség az őt megelőző $\sigma_{n ; 1}, \sigma_{n ; 2}, \ldots, \sigma_{n ; p-1}$ összegekre és így ebben rejlik az ismertetett módszer előnye az előző fejezetekben bemutatott módszerekhez képest, azaz nem kell „,bajlódni” a megelőző összegek kiszámításával, hiszen sikerült egy zárt formulát felállítani a $\sigma_{n ; p}$ kiszámítására. 


\subsubsection{Speciális esetek a kapott összefüggésre}

A kapott összefüggés az előző fejezetekben már megismert hatványösszegek „egyszerübb” kiszámítását teszi lehetővé. Ehhez lássuk néhány konkrét $p$ érték esetén azt az esetet, mikor a $\sigma_{n ; p}=S_{p}=1^{p}+2^{p}+3^{p}+\ldots+n^{p}$.

Ha $p=3$, akkor

$\begin{array}{lcccccccc}a_{i} & 1 & & 8 & & 27 & & 64 & \\ \Delta a_{i} & & 7 & & 19 & & 37 & & 61 \\ \Delta^{2} a_{i} & & & 12 & & 18 & & 24 & \\ \Delta^{3} a_{i} & & & & 6 & & 6 & & \end{array}$

vagyis $a_{1}=1 ; \Delta a_{1}=7 ; \Delta^{2} a_{1}=12 ; \Delta^{3} a_{1}=6$.

$$
\begin{aligned}
& S_{3}=\sigma_{n ; 3}=\left(\begin{array}{l}
n \\
1
\end{array}\right) \cdot a_{1}+\left(\begin{array}{l}
n \\
2
\end{array}\right) \cdot \Delta a_{1}+\left(\begin{array}{l}
n \\
3
\end{array}\right) \cdot \Delta^{2} a_{1}+\left(\begin{array}{l}
n \\
4
\end{array}\right) \cdot \Delta^{3} a_{1}=\left(\begin{array}{l}
n \\
1
\end{array}\right) \cdot 1+\left(\begin{array}{l}
n \\
2
\end{array}\right) \cdot 7+\left(\begin{array}{l}
n \\
3
\end{array}\right) \cdot 12+\left(\begin{array}{l}
n \\
4
\end{array}\right) \cdot 6= \\
& =n+\frac{n(n-1)}{2} \cdot 7+\frac{n(n-1)(n-2)}{6} \cdot 12+\frac{n(n-1)(n-2)(n-3)}{24} \cdot 6= \\
& =\frac{n}{4} \cdot\left(4+14 n-14+8 n^{2}-24 n+16+n^{3}-6 n^{2}+11 n-6\right)=\frac{n}{4} \cdot\left(n^{3}+2 n^{2}+n\right)= \\
& =\frac{n^{2}}{4} \cdot\left(n^{2}+2 n+1\right)=\frac{n^{2}(n+1)^{2}}{4} .
\end{aligned}
$$

Tehát:

$$
S_{3}=1^{3}+2^{3}+3^{3}+\ldots+n^{3}=\frac{n^{2}(n+1)^{2}}{4} .
$$

Ha $p=4$, akkor

$\begin{array}{llllllllllll}a_{i} & 1 & & 16 & & 81 & & 256 & & 625 & & 1296 \\ \Delta a_{i} & & 15 & & 65 & & 175 & & 369 & & 671 & \\ \Delta^{2} a_{i} & & & 50 & & 110 & & 194 & & 302 & & \\ \Delta^{3} a_{i} & & & & 60 & & 84 & & 108 & & \\ \Delta^{4} a_{i} & & & & & 24 & & 24 & & & & \end{array}$

vagyis $a_{1}=1 ; \Delta a_{1}=15 ; \Delta^{2} a_{1}=50 ; \Delta^{3} a_{1}=60 ; \Delta^{4} a_{1}=24$.

$$
\begin{aligned}
& S_{4}=\sigma_{n ; 4}=\left(\begin{array}{l}
n \\
1
\end{array}\right) \cdot a_{1}+\left(\begin{array}{l}
n \\
2
\end{array}\right) \cdot \Delta a_{1}+\left(\begin{array}{l}
n \\
3
\end{array}\right) \cdot \Delta^{2} a_{1}+\left(\begin{array}{l}
n \\
4
\end{array}\right) \cdot \Delta^{3} a_{1}+\left(\begin{array}{l}
n \\
5
\end{array}\right) \cdot \Delta^{4} a_{1}= \\
& =\left(\begin{array}{l}
n \\
1
\end{array}\right) \cdot 1+\left(\begin{array}{l}
n \\
2
\end{array}\right) \cdot 15+\left(\begin{array}{l}
n \\
3
\end{array}\right) \cdot 50+\left(\begin{array}{l}
n \\
4
\end{array}\right) \cdot 60+\left(\begin{array}{l}
n \\
5
\end{array}\right) \cdot 24= \\
& =n+\frac{n(n-1)}{2} \cdot 15+\frac{n(n-1)(n-2)}{6} \cdot 50+\frac{n(n-1)(n-2)(n-3)}{24} \cdot 60+\frac{n(n-1)(n-2)(n-3)(n-4)}{120} \cdot 24 .
\end{aligned}
$$

A zárójelek felbontása és az összevonások után kapjuk, hogy 


$$
S_{4}=\frac{n(n+1)}{30} \cdot\left(6 n^{3}+9 n^{2}+n-1\right)=\frac{n(n+1)}{30} \cdot(2 n+1)\left(3 n^{2}+3 n-1\right) .
$$

Tehát:

$$
S_{4}=1^{4}+2^{4}+3^{4}+\ldots+n^{4}=\frac{n(n+1)(2 n+1)\left(3 n^{2}+3 n-1\right)}{30} .
$$

\begin{tabular}{|c|c|c|c|c|c|c|c|c|c|c|c|}
\hline$a_{i} \quad 1$ & & 32 & & 243 & & 1024 & & 3125 & & 7776 & \\
\hline$\Delta a_{i}$ & 31 & & 211 & & 781 & & 2101 & & 4651 & & 9031 \\
\hline$\Delta^{2} a_{i}$ & & 180 & & 570 & & 1320 & & 2550 & & 4380 & \\
\hline$\Delta^{3} a_{i}$ & & & 390 & & 750 & & 1230 & & 1830 & & \\
\hline$\Delta^{4} a_{i}$ & & & & 360 & & 480 & & 600 & & & \\
\hline$\Delta^{5} a_{i}$ & & & & & 120 & & 120 & & & & \\
\hline
\end{tabular}

Ha $p=5$, akkor

vagyis $a_{1}=1 ; \Delta a_{1}=31 ; \Delta^{2} a_{1}=180 ; \Delta^{3} a_{1}=390 ; \Delta^{4} a_{1}=360 ; \Delta^{5} a_{1}=120$.

$$
\begin{aligned}
& S_{5}=\sigma_{n ; 5}=\left(\begin{array}{l}
n \\
1
\end{array}\right) \cdot a_{1}++\left(\begin{array}{l}
n \\
2
\end{array}\right) \cdot \Delta a_{1}+\left(\begin{array}{l}
n \\
3
\end{array}\right) \cdot \Delta^{2} a_{1}+\left(\begin{array}{l}
n \\
4
\end{array}\right) \cdot \Delta^{3} a_{1}+\left(\begin{array}{l}
n \\
5
\end{array}\right) \cdot \Delta^{4} a_{1}+\left(\begin{array}{l}
n \\
6
\end{array}\right) \cdot \Delta^{5} a_{1}= \\
& =\left(\begin{array}{l}
n \\
1
\end{array}\right) \cdot 1+\left(\begin{array}{l}
n \\
2
\end{array}\right) \cdot 31+\left(\begin{array}{l}
n \\
3
\end{array}\right) \cdot 180+\left(\begin{array}{l}
n \\
4
\end{array}\right) \cdot 390+\left(\begin{array}{l}
n \\
5
\end{array}\right) \cdot 360+\left(\begin{array}{l}
n \\
6
\end{array}\right) \cdot 120= \\
& =n+\frac{n(n-1)}{2} \cdot 31+\frac{n(n-1)(n-2)}{6} \cdot 180+\frac{n(n-1)(n-2)(n-3)}{24} \cdot 390+ \\
& +\frac{n(n-1)(n-2)(n-3)(n-4)}{120} \cdot 360+\frac{n(n-1)(n-2)(n-3)(n-4)(n-5)}{720} \cdot 120 .
\end{aligned}
$$

A műveletek elvégzése és az összevonások után kapjuk, hogy

$$
S_{5}=\frac{n^{2}(n+1)}{12} \cdot\left(2 n^{3}+4 n^{2}+n-1\right)=\frac{n^{2}(n+1)^{2}}{12} \cdot\left(2 n^{2}+2 n-1\right) .
$$

Tehát:

$$
S_{5}=1^{5}+2^{5}+3^{5}+\ldots+n^{5}=\frac{n^{2}(n+1)^{2}\left(2 n^{2}+2 n-1\right)}{12} .
$$




\subsubsection{Speciális esetek a kapott összefüggésre számtani sorozatok esetén}

A következőkben az első néhány $p$ érték mellett tanulmányozni fogjuk azt az esetet, amikor $\sigma_{n ; p}=S_{p}(a, d)=a_{1}^{p}+a_{2}^{p}+a_{3}^{p}+\ldots+a_{n}^{p}=\sum_{k=1}^{n}[a+(k-1) \cdot d]^{p}$,

ahol $\left\{a_{n}\right\}_{n \geq 1}$ egy számtani sorozat, melynek első tagja $a$, differenciája $d$ és $a, d \in R$.

A speciális esetek vizsgálatát logikailag a következőképpen végezzük: a $p=1 ; 2 ; 3$ kitevőkre történik a fö felosztás, majd ezen belül megnézzük az $a=1$ esetben a $d=1 ; 2$ eseteket, majd harmadikként az $a=2, d=3$, míg negyedikként az $a=5, d=6$ eset eredményeit írjuk fel.

Ha $p=1$, akkor

$\begin{array}{llllll}a_{i} & a & & a+d & & a+2 d \\ \Delta a_{i} & & d & & d & \end{array}$

vagyis $a_{1}=a ; \Delta a_{1}=d$.

Ekkor

$$
\begin{aligned}
& \sigma_{n ; 1}=\left(\begin{array}{l}
n \\
1
\end{array}\right) \cdot a_{1}+\left(\begin{array}{l}
n \\
2
\end{array}\right) \cdot \Delta a_{1}=\left(\begin{array}{l}
n \\
1
\end{array}\right) \cdot a+\left(\begin{array}{l}
n \\
2
\end{array}\right) \cdot d=n a+\frac{n(n-1)}{2} \cdot d= \\
& =\frac{n}{2} \cdot[2 a+(n-1) d]=\frac{n}{2} \cdot(n d+2 a-d) .
\end{aligned}
$$

Tehát:

$$
S_{1}(a, d)=\sigma_{n ; 1}=\frac{n}{2} \cdot(n d+2 a-d) .
$$

\section{$\underline{\text { 4. Megjegyzés }}$}

Szemléletes bizonyítás az $S_{1}(a, d)$ kiszámítására (4.1.1. ábra):

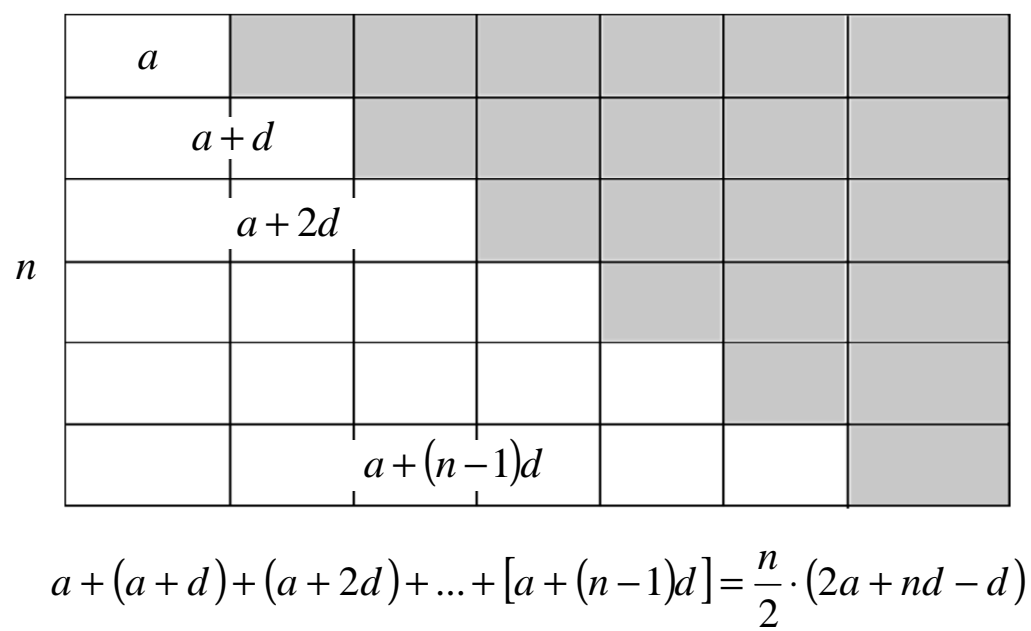

\subsection{1. ábra}

Ezen összefüggés speciális esetei:

$$
\begin{aligned}
& a=1, d=1 \\
& S_{1}(1,1)=1+2+3+\ldots+n=\frac{n}{2} \cdot(n+1) .
\end{aligned}
$$




$$
\begin{aligned}
& a=1, d=2 \\
& S_{1}(1,2)=1+3+5+\ldots+(2 n-1)=\frac{n}{2} \cdot 2 n=n^{2} . \\
& a=2, d=3 \\
& S_{1}(2,3)=2+5+8+\ldots+(3 n-1)=\frac{n}{2} \cdot(3 n+1) . \\
& a=5, d=6 \\
& S_{1}(5,6)=5+11+17+\ldots+(6 n-1)=\frac{n}{2} \cdot(6 n+4)=3 n^{2}+2 n .
\end{aligned}
$$

\section{$\underline{5 . \text { Megjegyzés }}$}

Szemléletes bizonyítás az $S_{1}(1,2)$ kiszámítására (4.1.2. ábra):

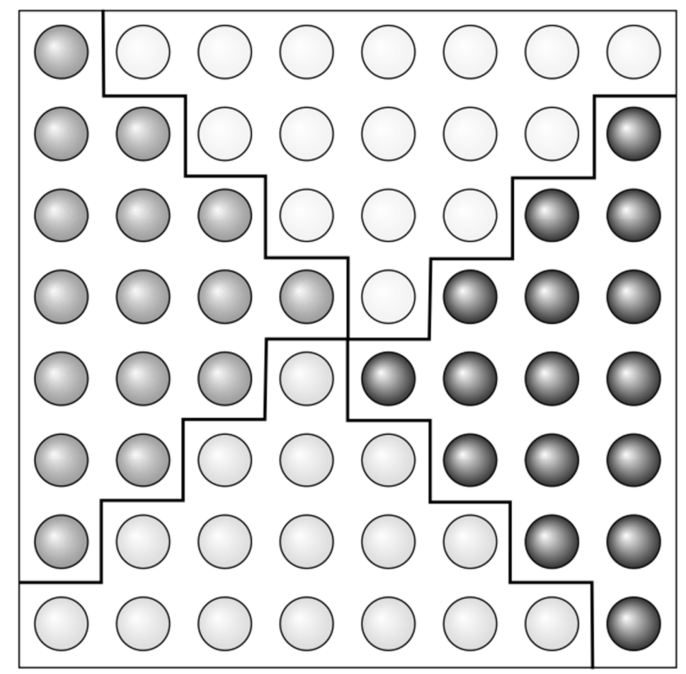

$$
1+3+5+\ldots+(2 n-1)=\frac{1}{4} \cdot(2 n)^{2}=n^{2}
$$

\subsection{2. ábra}

Ha $p=2$, akkor

$$
\begin{aligned}
& \begin{array}{lllll}
a_{i} & a^{2} & (a+d)^{2} & (a+2 d)^{2} & (a+3 d)^{2}
\end{array} \\
& \Delta a_{i} \quad 2 a d+d^{2} \quad 2 a d+3 d^{2} \quad 2 a d+5 d^{2} \\
& \Delta^{2} a_{i} \quad 2 d^{2} \quad 2 d^{2}
\end{aligned}
$$

vagyis $a_{1}=a^{2} ; \Delta a_{1}=2 a d+d^{2} ; \Delta^{2} a_{1}=2 d^{2}$.

Ekkor

$$
\begin{aligned}
& \sigma_{n ; 2}=\left(\begin{array}{l}
n \\
1
\end{array}\right) \cdot a_{1}+\left(\begin{array}{l}
n \\
2
\end{array}\right) \cdot \Delta a_{1}+\left(\begin{array}{l}
n \\
3
\end{array}\right) \cdot \Delta^{2} a_{1}=\left(\begin{array}{l}
n \\
1
\end{array}\right) \cdot a^{2}+\left(\begin{array}{l}
n \\
2
\end{array}\right) \cdot\left(2 a d+d^{2}\right)+\left(\begin{array}{l}
n \\
3
\end{array}\right) \cdot 2 d^{2}= \\
& =n \cdot a^{2}+\frac{n(n-1)}{2} \cdot\left(2 a d+d^{2}\right)+\frac{n(n-1)(n-2)}{6} \cdot 2 d^{2}= \\
& =\frac{n}{6} \cdot\left[6 a^{2}+3(n-1)\left(2 a d+d^{2}\right)+2\left(n^{2}-3 n+2\right) d^{2}\right] .
\end{aligned}
$$


A müveletek elvégzése és az összevonások után kapjuk, hogy

$$
\sigma_{n ; 2}=\frac{n}{6} \cdot\left[2 n^{2} d^{2}+3 n d(2 a-d)+6 a^{2}-6 a d+d^{2}\right] .
$$

Tehát:

$$
S_{2}(a, d)=\sigma_{n ; 2}=\frac{n}{6} \cdot\left[2 n^{2} d^{2}+3 n d(2 a-d)+6 a^{2}-6 a d+d^{2}\right] .
$$

A kapott felírás speciális esetei:

$$
\begin{aligned}
& a=1, d=1 \\
& S_{2}(1,1)=1^{2}+2^{2}+3^{2}+\ldots+n^{2}=\frac{n}{6} \cdot\left(2 n^{2}+3 n+1\right)=\frac{n(n+1)(2 n+1)}{6} . \\
& a=1, d=2 \\
& S_{2}(1,2)=1^{2}+3^{2}+5^{2}+\ldots+(2 n-1)^{2}=\frac{n}{6} \cdot\left(8 n^{2}-2\right)=\frac{n\left(4 n^{2}-1\right)}{3} . \\
& a=2, d=3 \\
& S_{2}(2,3)=2^{2}+5^{2}+8^{2}+\ldots+(3 n-1)^{2}=\frac{n}{6} \cdot\left(18 n^{2}+9 n-3\right)=\frac{n}{2} \cdot\left(6 n^{2}+3 n-1\right) . \\
& a=5, d=6 \\
& S_{2}(5,6)=5^{2}+11^{2}+17^{2}+\ldots+(6 n-1)^{2}=\frac{n}{6} \cdot\left(72 n^{2}+72 n+6\right)=n\left(12 n^{2}+12 n+1\right) .
\end{aligned}
$$

\section{$\underline{\text { 6. Megjegyzés }}$}

Szemléletes bizonyítás az $S_{2}(1,1)$ kiszámítására (4.1.3. ábra):

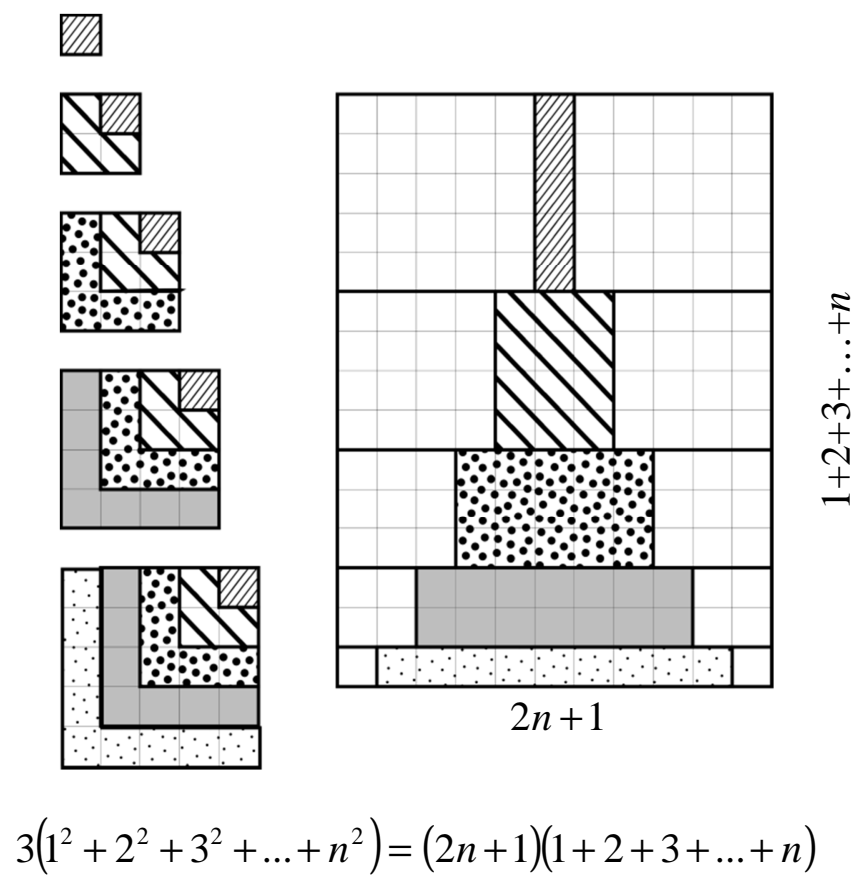

4.1.3. ábra 
Ha $p=3$, akkor

$$
\begin{aligned}
& \begin{array}{lllll}
a_{i} & a^{3} & (a+d)^{3} & (a+2 d)^{3} & (a+3 d)^{3}
\end{array} \\
& \Delta a_{i} \quad 3 a^{2} d+3 a d^{2}+d^{3} \quad 3 a^{2} d+9 a d^{2}+7 d^{3} \quad 3 a^{2} d+15 a d^{2}+19 d^{3} \\
& \Delta^{2} a_{i} \quad 6 a d^{2}+6 d^{3} \quad 6 a d^{2}+12 d^{3}
\end{aligned}
$$

vagyis $a_{1}=a^{3} ; \Delta a_{1}=3 a^{2} d+3 a d^{2}+d^{3} ; \Delta^{2} a_{1}=6 a d^{2}+6 d^{3} ; \Delta^{3} a_{1}=6 d^{3}$.

Ekkor

$$
\begin{aligned}
& \sigma_{n ; 3}=\left(\begin{array}{l}
n \\
1
\end{array}\right) \cdot a_{1}+\left(\begin{array}{l}
n \\
2
\end{array}\right) \cdot \Delta a_{1}+\left(\begin{array}{l}
n \\
3
\end{array}\right) \cdot \Delta^{2} a_{1}+\left(\begin{array}{l}
n \\
4
\end{array}\right) \cdot \Delta^{3} a_{1}= \\
& =\left(\begin{array}{l}
n \\
1
\end{array}\right) \cdot a^{3}+\left(\begin{array}{l}
n \\
2
\end{array}\right) \cdot\left(3 a^{2} d+3 a d^{2}+d^{3}\right)+\left(\begin{array}{l}
n \\
3
\end{array}\right) \cdot\left(6 a d^{2}+6 d^{3}\right)+\left(\begin{array}{l}
n \\
4
\end{array}\right) \cdot 6 d^{3}= \\
& =n \cdot a^{3}+\frac{n(n-1)}{2} \cdot\left(3 a^{2} d+3 a d^{2}+d^{3}\right)+\frac{n(n-1)(n-2)}{6} \cdot\left(6 a d^{2}+6 d^{3}\right)+\frac{n(n-1)(n-2)(n-3)}{24} \cdot 6 d^{3}= \\
& =\frac{n}{4} \cdot\left[4 a^{3}+2(n-1)\left(3 a^{2} d+3 a d^{2}+d^{3}\right)+4\left(n^{2}-3 n+2\right)\left(a d^{2}+d^{3}\right)+\left(n^{3}-6 n^{2}+11 n-6\right) d^{3}\right] .
\end{aligned}
$$

A müveletek elvégzése és az összevonások után kapjuk, hogy

$$
\sigma_{n ; 3}=\frac{n}{4} \cdot\left[n^{3} d^{3}+2 n^{2} d^{2}(2 a-d)+n d\left(6 a^{2}-6 a d+d^{2}\right)+4 a^{3}-6 a^{2} d+2 a d^{2}\right] .
$$

Tehát:

$$
S_{3}(a, d)=\sigma_{n ; 3}=\frac{n}{4} \cdot\left[n^{3} d^{3}+2 n^{2} d^{2}(2 a-d)+n d\left(6 a^{2}-6 a d+d^{2}\right)+4 a^{3}-6 a^{2} d+2 a d^{2}\right] .
$$

A kapott összefüggés speciális esetei:

$$
\begin{aligned}
& a=1, d=1 \\
& S_{3}(1,1)=1^{3}+2^{3}+3^{3}+\ldots+n^{3}=\frac{n}{4} \cdot\left(n^{3}+2 n^{2}+n\right)=\frac{n^{2}(n+1)^{2}}{4} . \\
& a=1, d=2 \\
& S_{3}(1,2)=1^{3}+3^{3}+5^{3}+\ldots+(2 n-1)^{3}=\frac{n}{4} \cdot\left(8 n^{3}-4 n\right)=n^{2}\left(2 n^{2}-1\right) . \\
& a=2, d=3 \\
& S_{3}(2,3)=2^{3}+5^{3}+8^{3}+\ldots+(3 n-1)^{3}=\frac{n}{4} \cdot\left(27 n^{3}+18 n^{2}-9 n-4\right)=\frac{n(3 n+1)\left(9 n^{2}+3 n-4\right)}{4} . \\
& a=5, d=6 \\
& S_{3}(5,6)=5^{3}+11^{3}+17^{3}+\ldots+(6 n-1)^{3}=\frac{n}{4} \cdot\left(216 n^{3}+288 n^{2}+36 n-40\right)= \\
& =n(3 n+2)\left(18 n^{2}+12 n-5\right) \text {. }
\end{aligned}
$$




\section{Megjegyzés}

Szemléletes bizonyítás az $S_{3}(1,2)$ kiszámítására (4.1.4. ábra):

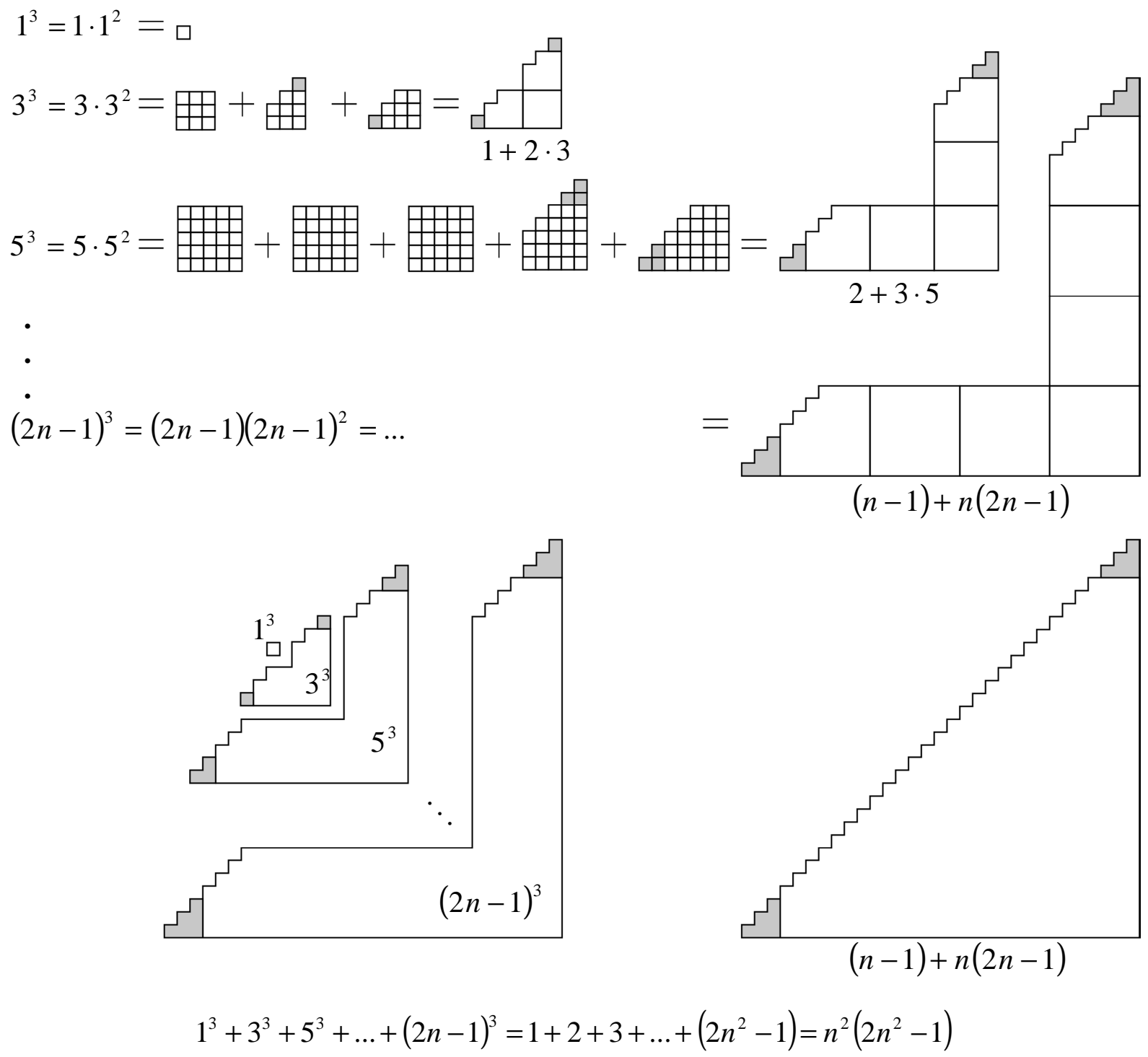

\subsection{4. ábra}

A korábbi fejezetekben leírtakra való tekintettel itt nyilván csak a $p=1 ; 2 ; 3$ kitevőkre felírt összesen 12 sajátos esetet mutattunk be, mégis több érdekes eredményt kaptunk. Ezek közül megemlítjük például, hogy az első $n$, hattal osztva maradékul egyet adó pozitív egészek négyzeteinek és köbeinek az összege mindig osztható $n$-nel, az első $n$ páratlan szám négyzeteinek összege három egymást követő egész szám szorzatának a hatoda stb. További $p$ kre, $a$-kra és $d$-kre felírva az összegzési képleteket újabb szép összefüggéseket lehetne meghatározni.

Az e fejezetben tárgyaltak fő mondanivalója abban foglalható össze, hogy a differenciasorozat fogalmának bevezetése után először leírtuk, hogy hogyan értelmezzük a $p$-edrendủ számtani sorozatot, majd bebizonyítottunk egy fontos tételt, belátva azt, hogy egy $p$-edrendủ számtani sorozat $k$-adik tagját egy $k$-ban $p$-edfokú polinom adja meg. Ezután megadtunk egy 
összefüggést a magasabb rendủ számtani sorozat első $n$ tagja összegének kiszámítására, leírtuk a képlet alkalmazását három speciális esetre $(p=3 ; 4 ; 5)$, s végezetül felírtuk a számtani sorozatra való alkalmazás 12 speciális esetét. Ez a módszer azért nagyon hasznos, mert a végeredmény megadásához nincs szükségünk az adott összeget megelőző összegek eredményeire, azaz sikerült megadni a hatványösszegek ún. zárt alakos felírását.

\section{2. Összefüggés levezetése lineáris algebrai eszközökkel}

A hatványösszegek kiszámítása megvalósítható lineáris algebrai eszközökkel is. A következőkben a lineáris egyenletrendszerekre vonatkozó ismeretek és a Cramer-szabály segítségével fogjuk a meghatározandó összegek kiszámítására szolgáló összefüggéseket megkeresni ([15]). Az említettek mellett ide már a determinánsokra vonatkozó alapvető ismeretek is szükségeltetnek.

Ez a módszer akár középiskolában - természetesen elsősorban emelt szintű csoportokban, tagozatos osztályokban vagy szakkörön - is bemutatható és tárgyalható a diákok tudásszintjének függvényében.

\subsection{1. Összefüggés felírása lineáris algebrai eszközök segítségével}

Legyen $k$ egy természetes szám és $a$ egy tetszőleges valós szám.

Induljunk ki az

$$
(a+1)^{k+1}=\left(\begin{array}{c}
k+1 \\
0
\end{array}\right) \cdot a^{k+1}+\left(\begin{array}{c}
k+1 \\
1
\end{array}\right) \cdot a^{k}+\left(\begin{array}{c}
k+1 \\
2
\end{array}\right) \cdot a^{k-1}+\ldots+\left(\begin{array}{c}
k+1 \\
k
\end{array}\right) \cdot a+\left(\begin{array}{c}
k+1 \\
k+1
\end{array}\right)
$$

azonosságból, melyet átrendezve és felhasználva, hogy $\left(\begin{array}{c}k+1 \\ 0\end{array}\right)=1$ kapjuk hogy:

$$
(a+1)^{k+1}-a^{k+1}=\left(\begin{array}{c}
k+1 \\
1
\end{array}\right) \cdot a^{k}+\left(\begin{array}{c}
k+1 \\
2
\end{array}\right) \cdot a^{k-1}+\ldots+\left(\begin{array}{c}
k+1 \\
k
\end{array}\right) \cdot a+\left(\begin{array}{c}
k+1 \\
k+1
\end{array}\right) .
$$

A kapott (4.2.1) összefüggésben rendre helyettesítsük be az $a$ helyére az $1,2, \ldots, n$ természetes számokat, majd a kapott egyenlőségeket oldalanként összegezzük.

Ekkor

$$
\begin{aligned}
& \sum_{i=1}^{n}\left[(i+1)^{k+1}-i^{k+1}\right]=\sum_{i=1}^{n}\left[\left(\begin{array}{c}
k+1 \\
1
\end{array}\right) \cdot i^{k}+\left(\begin{array}{c}
k+1 \\
2
\end{array}\right) \cdot i^{k-1}+\ldots+\left(\begin{array}{c}
k+1 \\
k
\end{array}\right) \cdot i+\left(\begin{array}{c}
k+1 \\
k+1
\end{array}\right)\right]= \\
& =\left(\begin{array}{c}
k+1 \\
1
\end{array}\right) \cdot \sum_{i=1}^{n} i^{k}+\left(\begin{array}{c}
k+1 \\
2
\end{array}\right) \cdot \sum_{i=1}^{n} i^{k-1}+\ldots+\left(\begin{array}{c}
k+1 \\
k
\end{array}\right) \cdot \sum_{i=1}^{n} i+\left(\begin{array}{c}
k+1 \\
k+1
\end{array}\right) \cdot \sum_{i=1}^{n} 1 .
\end{aligned}
$$

A baloldalon egy teleszkópikus összeg található, amely az összevonások után $(n+1)^{k+1}-1^{k+1}$ lesz, vagyis

$$
(n+1)^{k+1}-1=\left(\begin{array}{c}
k+1 \\
1
\end{array}\right) \cdot S_{k}+\left(\begin{array}{c}
k+1 \\
2
\end{array}\right) \cdot S_{k-1}+\ldots+\left(\begin{array}{c}
k+1 \\
k
\end{array}\right) \cdot S_{1}+\left(\begin{array}{c}
k+1 \\
k+1
\end{array}\right) \cdot n .
$$

Átrendezve kapjuk, hogy 


$$
(n+1)^{k+1}=\left(\begin{array}{c}
k+1 \\
k+1
\end{array}\right) \cdot(n+1)+\left(\begin{array}{c}
k+1 \\
k
\end{array}\right) \cdot S_{1}+\ldots+\left(\begin{array}{c}
k+1 \\
2
\end{array}\right) \cdot S_{k-1}+\left(\begin{array}{c}
k+1 \\
1
\end{array}\right) \cdot S_{k} .
$$

Vezessük be a következő jelölést: legyen $X_{0}=n+1$.

Rendeljünk a (4.2.2) összefüggéshez egy lineáris egyenletrendszert, amelyet úgy kapunk, hogy $k$-nak rendre $0,1,2, \ldots, p$ értékeket adunk. Így az alábbi egyenletrendszerhez jutunk:

$$
\left\{\begin{array}{l}
n+1=\left(\begin{array}{l}
1 \\
1
\end{array}\right) \cdot X_{0} \\
(n+1)^{2}=\left(\begin{array}{l}
2 \\
2
\end{array}\right) \cdot X_{0}+\left(\begin{array}{l}
2 \\
1
\end{array}\right) \cdot S_{1} \\
(n+1)^{3}=\left(\begin{array}{l}
3 \\
3
\end{array}\right) \cdot X_{0}+\left(\begin{array}{l}
3 \\
2
\end{array}\right) \cdot S_{1}+\left(\begin{array}{l}
3 \\
1
\end{array}\right) \cdot S_{2} \\
---------------------------- \\
(n+1)^{p}=\left(\begin{array}{l}
p \\
p
\end{array}\right) \cdot X_{0}+\left(\begin{array}{c}
p \\
p-1
\end{array}\right) \cdot S_{1}+\ldots+\left(\begin{array}{c}
p \\
2
\end{array}\right) \cdot S_{p-2}+\left(\begin{array}{c}
p \\
1
\end{array}\right) \cdot S_{p-1} \\
(n+1)^{p+1}=\left(\begin{array}{c}
p+1 \\
p+1
\end{array}\right) \cdot X_{0}+\left(\begin{array}{c}
p+1 \\
p
\end{array}\right) \cdot S_{1}+\ldots+\left(\begin{array}{c}
p+1 \\
2
\end{array}\right) \cdot S_{p-1}+\left(\begin{array}{c}
p+1 \\
1
\end{array}\right) \cdot S_{p} .
\end{array} .\right.
$$

Az így kapott $(p+1)$ egyenletből álló egyenletrendszerben tekintsük ismeretleneknek az $X_{0}, S_{1}, S_{2}, \ldots, S_{p}$,szimbólumokat”. Az $X_{0}$-t csak azért tekintjük ismeretlennek, mert ezáltal „,egyszerübb” az egyenletrendszer felírása, megoldása pedig könnyebben algoritmizálható. Így az egyenletrendszer együtthatómátrixa egy alsó háromszögmátrix, melynek determinánsa:

$$
\begin{aligned}
& D=\left|\begin{array}{lccccc}
\left(\begin{array}{l}
1 \\
1
\end{array}\right) & 0 & 0 & \ldots & 0 & 0 \\
\left(\begin{array}{l}
2 \\
2
\end{array}\right) & \left(\begin{array}{l}
2 \\
1
\end{array}\right) & 0 & \ldots & 0 & 0 \\
\left(\begin{array}{l}
3 \\
3
\end{array}\right) & \left(\begin{array}{l}
3 \\
2
\end{array}\right) & \left(\begin{array}{l}
3 \\
1
\end{array}\right) & \ldots & 0 & 0 \\
\hdashline\left(\begin{array}{l}
p \\
p
\end{array}\right) & \left(\begin{array}{c}
p \\
p-1
\end{array}\right) & \left(\begin{array}{c}
p \\
p-2
\end{array}\right) & \ldots & --- & --- \\
\left(\begin{array}{c}
p \\
p+1 \\
p+1
\end{array}\right) & \left(\begin{array}{c}
p+1 \\
p
\end{array}\right) & \left(\begin{array}{c}
p+1 \\
p-1
\end{array}\right) & \ldots & \left(\begin{array}{c}
p+1 \\
2
\end{array}\right) & \left(\begin{array}{c}
p+1 \\
1
\end{array}\right)
\end{array}\right|= \\
& =\left(\begin{array}{l}
1 \\
1
\end{array}\right) \cdot\left(\begin{array}{l}
2 \\
1
\end{array}\right) \cdot\left(\begin{array}{l}
3 \\
1
\end{array}\right) \cdot \ldots \cdot\left(\begin{array}{c}
p \\
1
\end{array}\right) \cdot\left(\begin{array}{c}
p+1 \\
1
\end{array}\right)=(p+1) ! .
\end{aligned}
$$

Mivel $D=(p+1) ! \neq 0$, alkalmazható a Cramer-szabály. A megfelelő ismeretlenekhez hozzárendelt determinánsokat megkapjuk, ha $D$-ben az oszlopvektorokat rendre a szabad tagok oszlopvektorával helyettesítjük. Így minden $p$ esetén a megfelelő determinánsokat 
kiszámítva, megkapjuk nemcsak az $S_{p}$-t, hanem az összes $p$-nél kisebb indexü $\left(X_{0}, S_{1}, S_{2}, \ldots, S_{p-1}\right)$ összegeket is.

Belátható, azonban az is, hogy ha rendre minden $p$ esetén csak az $S_{p}$-t számoljuk ki, akkor ennek eredményét megkaphatjuk úgy is, hogy a többi összeget nem ismerjük. Itt mutatkozik meg a módszer előnye a 3. fejezetben tárgyalt módszerekhez képest, ugyanis itt az $S_{p}$ kiszámításához nem kell ismernünk a megelőző $S_{1}, S_{2}, \ldots, S_{p-1}$ összegeket, azaz nincs szükség rekurziós összefüggés felírására.

Az $S_{p}$-nek megfelelő determináns:

$$
D_{p}=\left|\begin{array}{lccccc}
\left(\begin{array}{l}
1 \\
1
\end{array}\right) & 0 & 0 & \ldots & 0 & n+1 \\
\left(\begin{array}{l}
2 \\
2
\end{array}\right) & \left(\begin{array}{l}
2 \\
1
\end{array}\right) & 0 & \ldots & 0 & (n+1)^{2} \\
\left(\begin{array}{l}
3 \\
3
\end{array}\right) & \left(\begin{array}{l}
3 \\
2
\end{array}\right) & \left(\begin{array}{l}
3 \\
1
\end{array}\right) & \ldots & 0 & (n+1)^{3} \\
\hdashline-- & --- & --- & --- & --- & --- \\
\left(\begin{array}{l}
p \\
p
\end{array}\right) & \left(\begin{array}{c}
p \\
p-1
\end{array}\right) & \left(\begin{array}{c}
p \\
p-2
\end{array}\right) & \ldots & \left(\begin{array}{c}
p \\
1
\end{array}\right) & (n+1)^{p} \\
\left(\begin{array}{l}
p+1 \\
p+1
\end{array}\right) & \left(\begin{array}{c}
p+1 \\
p
\end{array}\right) & \left(\begin{array}{c}
p+1 \\
p-1
\end{array}\right) & \ldots & \left(\begin{array}{c}
p+1 \\
2
\end{array}\right) & (n+1)^{p+1}
\end{array}\right| .
$$

A Cramer-szabály szerint:

$S_{p}=\frac{D_{p}}{D}=\frac{1}{(p+1) !} \cdot D_{p}$,

ahol $p=1 ; 2 ; 3 ; \ldots$ (az $X_{0}$ kiszámításával nem foglalkozunk).

Tehát:

$$
S_{p}=\frac{1}{(p+1) !} \cdot\left|\begin{array}{cccccc}
\left(\begin{array}{l}
1 \\
1
\end{array}\right) & 0 & 0 & \ldots & 0 & n+1 \\
\left(\begin{array}{l}
2 \\
2
\end{array}\right) & \left(\begin{array}{l}
2 \\
1
\end{array}\right) & 0 & \ldots & 0 & (n+1)^{2} \\
\left(\begin{array}{l}
3 \\
3
\end{array}\right) & \left(\begin{array}{l}
3 \\
2
\end{array}\right) & \left(\begin{array}{l}
3 \\
1
\end{array}\right) & \ldots & 0 & (n+1)^{3} \\
--- & --- & --- & --- & --- & --- \\
\left(\begin{array}{l}
p \\
p
\end{array}\right) & \left(\begin{array}{c}
p \\
p-1
\end{array}\right) & \left(\begin{array}{c}
p \\
p-2
\end{array}\right) & \ldots & \left(\begin{array}{c}
p \\
1
\end{array}\right) & (n+1)^{p} \\
\left(\begin{array}{l}
p+1 \\
p+1
\end{array}\right) & \left(\begin{array}{c}
p+1 \\
p
\end{array}\right) & \left(\begin{array}{c}
p+1 \\
p-1
\end{array}\right) & \ldots & \left(\begin{array}{c}
p+1 \\
2
\end{array}\right) & (n+1)^{p+1}
\end{array}\right|,
$$

ahol $p=1 ; 2 ; 3 ; \ldots$. 


\subsubsection{Speciális esetek a kapott összefüggésre}

Vizsgáljunk meg három konkrét esetet az előbbiekben felírt formulára.

Ha $p=3$, akkor

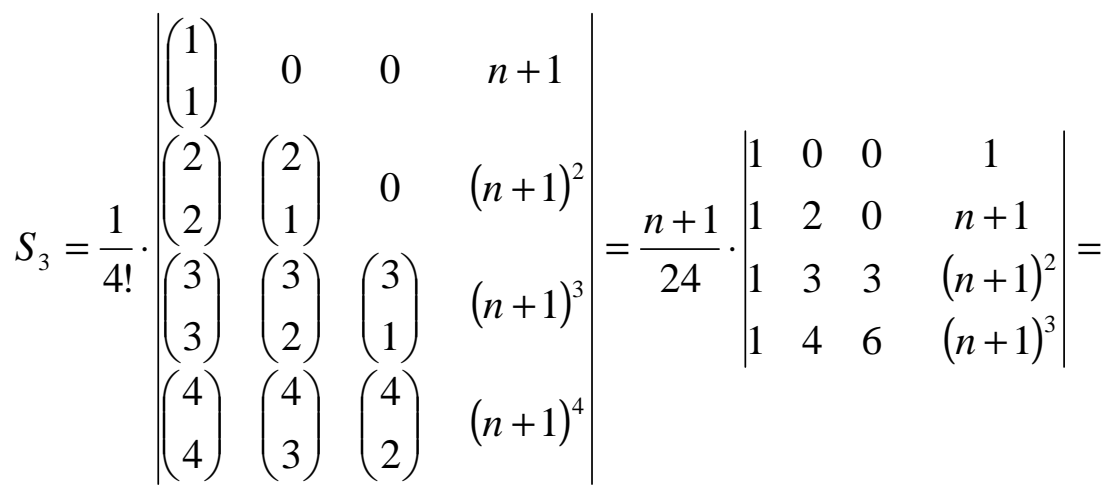

$$
\begin{aligned}
& =\frac{n+1}{24} \cdot\left|\begin{array}{cccc}
1 & 0 & 0 & 1 \\
0 & 2 & 0 & n \\
0 & 1 & 3 & n(n+1) \\
0 & 1 & 3 & n(n+1)^{2}
\end{array}\right|=\frac{n+1}{24} \cdot\left|\begin{array}{ccc}
2 & 0 & n \\
1 & 3 & n(n+1) \\
1 & 3 & n(n+1)^{2}
\end{array}\right|=\frac{n(n+1)}{8} \cdot\left|\begin{array}{ccc}
2 & 0 & 1 \\
1 & 1 & n+1 \\
1 & 1 & (n+1)^{2}
\end{array}\right|= \\
& =\frac{n(n+1)}{8} \cdot\left|\begin{array}{ccc}
2 & 0 & 1 \\
1 & 1 & n+1 \\
0 & 0 & n(n+1)
\end{array}\right|=\frac{n(n+1)}{8} \cdot\left|\begin{array}{cc}
2 & 1 \\
0 & n(n+1)
\end{array}\right|=\frac{n(n+1)}{8} \cdot[2 n(n+1)-0]=\frac{n^{2}(n+1)^{2}}{4} \text {. }
\end{aligned}
$$

Tehát:

$$
S_{3}=1^{3}+2^{3}+3^{3}+\ldots+n^{3}=\frac{n^{2}(n+1)^{2}}{4} .
$$

Ha $p=4$, akkor

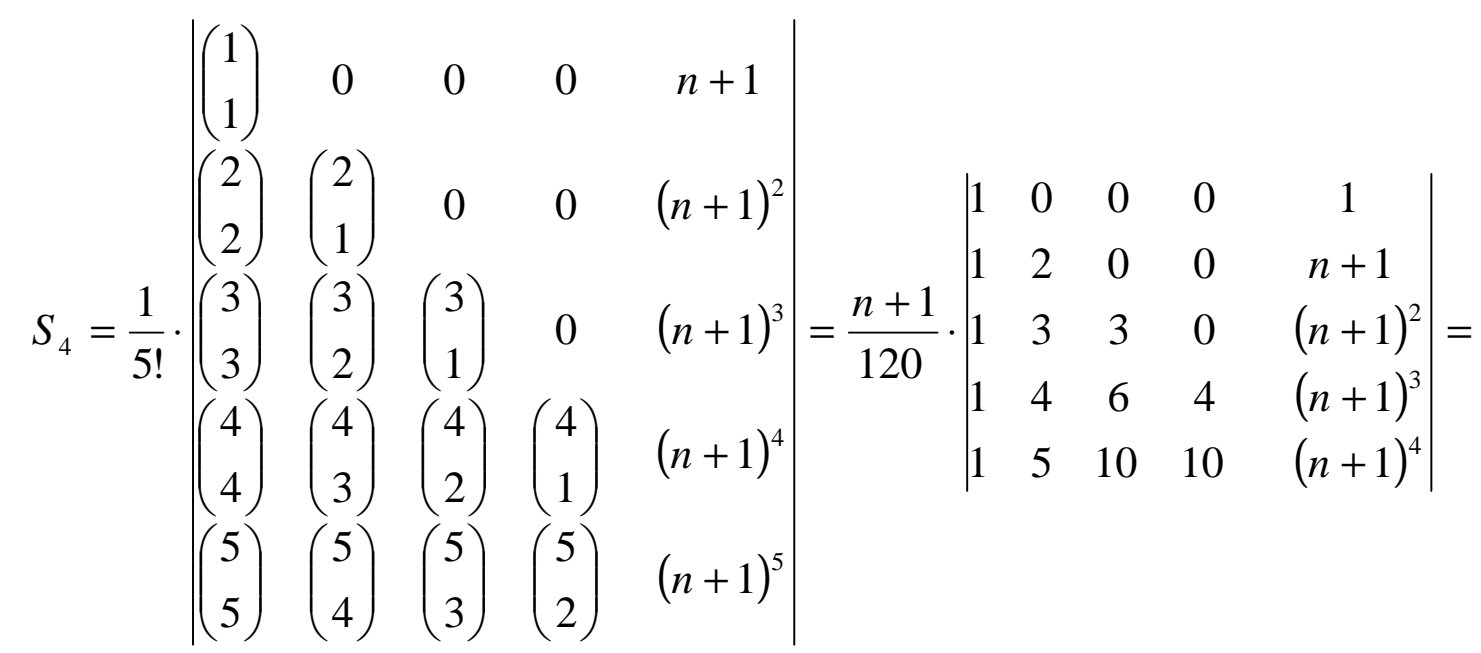




$$
\begin{aligned}
& =\frac{n+1}{120} \cdot\left|\begin{array}{ccccc}
1 & 0 & 0 & 0 & 1 \\
0 & 2 & 0 & 0 & n \\
0 & 1 & 3 & 0 & n(n+1) \\
0 & 1 & 3 & 4 & n(n+1)^{2} \\
0 & 1 & 4 & 6 & n(n+1)^{3}
\end{array}\right|=\frac{n+1}{120} \cdot\left|\begin{array}{cccc}
2 & 0 & 0 & n \\
1 & 3 & 0 & n(n+1) \\
1 & 3 & 4 & n(n+1)^{2} \\
1 & 4 & 6 & n(n+1)^{3}
\end{array}\right|= \\
& =\frac{n(n+1)}{120} \cdot\left|\begin{array}{cccc}
2 & 0 & 0 & 1 \\
1 & 3 & 0 & n+1 \\
1 & 3 & 4 & (n+1)^{2} \\
1 & 4 & 6 & (n+1)^{3}
\end{array}\right|=\frac{n(n+1)}{120} \cdot\left|\begin{array}{cccc}
2 & 0 & 0 & 1 \\
-1 & 3 & 0 & n \\
0 & 0 & 4 & n(n+1) \\
0 & 1 & 2 & n(n+1)^{2}
\end{array}\right|= \\
& =\frac{n(n+1)}{60} \cdot\left|\begin{array}{rrrc}
2 & 0 & 0 & 1 \\
-1 & 3 & 0 & n \\
0 & 0 & 2 & n(n+1) \\
0 & 1 & 1 & n(n+1)^{2}
\end{array}\right|=\frac{n(n+1)}{60} \cdot\left|\begin{array}{cccc}
0 & 6 & 0 & 2 n+1 \\
-1 & 3 & 0 & n \\
0 & 0 & 2 & n(n+1) \\
0 & 1 & 1 & n(n+1)^{2}
\end{array}\right|= \\
& =\frac{n(n+1)}{60} \cdot(-1) \cdot(-1) \cdot\left|\begin{array}{ccc}
6 & 0 & 2 n+1 \\
0 & 2 & n(n+1) \\
1 & 1 & n(n+1)^{2}
\end{array}\right|=\frac{n(n+1)}{60} \cdot\left|\begin{array}{ccc}
6 & 0 & 2 n+1 \\
-2 & 0 & -n(n+1)(2 n+1) \\
1 & 1 & n(n+1)^{2}
\end{array}\right|= \\
& =\frac{n(n+1)}{60} \cdot(-1) \cdot\left|\begin{array}{cc}
6 & 2 n+1 \\
-2 & -n(n+1)(2 n+1)
\end{array}\right|=-\frac{n(n+1)}{60} \cdot 2 \cdot(-1) \cdot(2 n+1) \cdot\left|\begin{array}{cc}
3 & 1 \\
1 & n(n+1)
\end{array}\right|= \\
& =\frac{n(n+1)(2 n+1)}{30} \cdot\left(3 n^{2}+3 n-1\right) \text {. }
\end{aligned}
$$

Tehát:

$$
S_{4}=1^{4}+2^{4}+3^{4}+\ldots+n^{4}=\frac{n(n+1)(2 n+1)\left(3 n^{2}+3 n-1\right)}{30} .
$$

Ha $p=5$, akkor

$$
\begin{aligned}
& \left(\begin{array}{l}
1 \\
1
\end{array}\right) \quad 0 \quad 000001 \mid
\end{aligned}
$$

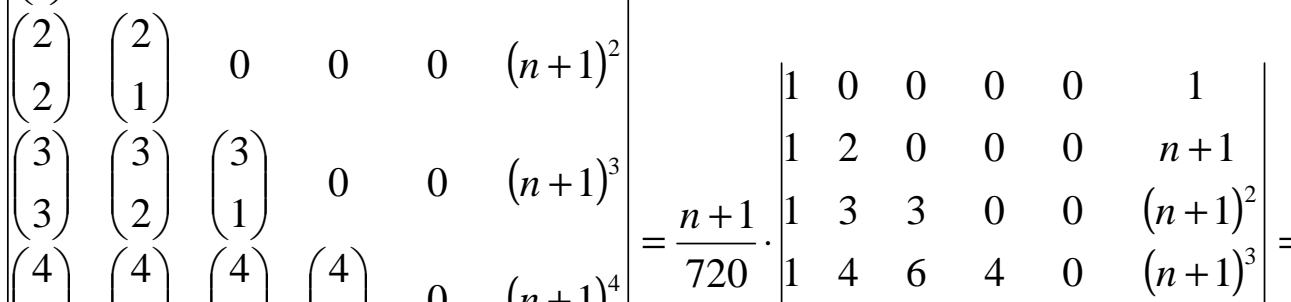

$$
\begin{aligned}
& \left(\begin{array}{l}
4 \\
4
\end{array}\right)\left(\begin{array}{l}
4 \\
3
\end{array}\right)\left(\begin{array}{l}
4 \\
2
\end{array}\right)\left(\begin{array}{l}
4 \\
1
\end{array}\right) \quad 0 \quad(n+1)^{4}\left(\begin{array}{l}
720 \\
1
\end{array} \begin{array}{cccccc}
1 & 4 & 6 & 4 & 0 & (n+1)^{3} \\
1 & 5 & 10 & 10 & 5 & (n+1)^{4}
\end{array} \mid=\right. \\
& \left(\begin{array}{l}
5 \\
5
\end{array}\right)\left(\begin{array}{l}
5 \\
4
\end{array}\right)\left(\begin{array}{l}
5 \\
3
\end{array}\right)\left(\begin{array}{l}
5 \\
2
\end{array}\right)\left(\begin{array}{l}
5 \\
1
\end{array}\right)(n+1)^{5}\left(\begin{array}{llllll}
1 & 6 & 15 & 20 & 15 & (n+1)^{5}
\end{array}\right. \\
& \left(\begin{array}{l}
6 \\
6
\end{array}\right)\left(\begin{array}{l}
6 \\
5
\end{array}\right)\left(\begin{array}{l}
6 \\
4
\end{array}\right)\left(\begin{array}{l}
6 \\
3
\end{array}\right)\left(\begin{array}{l}
6 \\
2
\end{array}\right)(n+1)^{6}
\end{aligned}
$$




$$
\begin{aligned}
& =\frac{n+1}{720} \cdot\left|\begin{array}{cccccc}
1 & 0 & 0 & 0 & 0 & 1 \\
0 & 2 & 0 & 0 & 0 & n \\
0 & 1 & 3 & 0 & 0 & n(n+1) \\
0 & 1 & 3 & 4 & 0 & n(n+1)^{2} \\
0 & 1 & 4 & 6 & 5 & n(n+1)^{3} \\
0 & 1 & 5 & 10 & 10 & n(n+1)^{4}
\end{array}\right|=\frac{n+1}{720} \cdot\left|\begin{array}{ccccc}
2 & 0 & 0 & 0 & n \\
1 & 3 & 0 & 0 & n(n+1) \\
1 & 3 & 4 & 0 & n(n+1)^{2} \\
1 & 4 & 6 & 5 & n(n+1)^{3} \\
1 & 5 & 10 & 10 & n(n+1)^{4}
\end{array}\right|= \\
& =\frac{n(n+1)}{720} \cdot\left|\begin{array}{ccccc}
2 & 0 & 0 & 0 & 1 \\
1 & 3 & 0 & 0 & n+1 \\
1 & 3 & 4 & 0 & (n+1)^{2} \\
1 & 4 & 6 & 5 & (n+1)^{3} \\
1 & 5 & 10 & 10 & (n+1)^{4}
\end{array}\right|=\frac{n(n+1)}{720} \cdot\left|\begin{array}{ccccc}
2 & 0 & 0 & 0 & 1 \\
-1 & 3 & 0 & 0 & n \\
0 & 0 & 4 & 0 & n(n+1) \\
0 & 1 & 2 & 5 & n(n+1)^{2} \\
0 & 1 & 4 & 5 & n(n+1)^{3}
\end{array}\right|= \\
& =\frac{n(n+1)}{720} \cdot 2 \cdot 5 \cdot\left|\begin{array}{ccccc}
2 & 0 & 0 & 0 & 1 \\
-1 & 3 & 0 & 0 & n \\
0 & 0 & 2 & 0 & n(n+1) \\
0 & 1 & 1 & 1 & n(n+1)^{2} \\
0 & 1 & 2 & 1 & n(n+1)^{3}
\end{array}\right|=\frac{n(n+1)}{72} \cdot\left|\begin{array}{ccccc}
0 & 6 & 0 & 0 & 2 n+1 \\
-1 & 3 & 0 & 0 & n \\
0 & 0 & 2 & 0 & n(n+1) \\
0 & 1 & 1 & 1 & n(n+1)^{2} \\
0 & 1 & 2 & 1 & n(n+1)^{3}
\end{array}\right|= \\
& =\frac{n(n+1)}{72} \cdot(-1) \cdot(-1) \cdot\left|\begin{array}{cccc}
6 & 0 & 0 & 2 n+1 \\
0 & 2 & 0 & n(n+1) \\
1 & 1 & 1 & n(n+1)^{2} \\
1 & 2 & 1 & n(n+1)^{3}
\end{array}\right|=\frac{n(n+1)}{72} \cdot\left|\begin{array}{cccc}
6 & 0 & 0 & 2 n+1 \\
0 & 2 & 0 & n(n+1) \\
1 & 1 & 1 & n(n+1)^{2} \\
0 & 1 & 0 & n^{2}(n+1)^{2}
\end{array}\right|= \\
& =\frac{n(n+1)}{72} \cdot 1 \cdot 1 \cdot\left|\begin{array}{ccc}
6 & 0 & 2 n+1 \\
0 & 2 & n(n+1) \\
0 & 1 & n^{2}(n+1)^{2}
\end{array}\right|=\frac{n(n+1)}{72} \cdot 6 \cdot\left|\begin{array}{ccc}
1 & 0 & 2 n+1 \\
0 & 2 & n(n+1) \\
0 & 1 & n^{2}(n+1)^{2}
\end{array}\right|= \\
& =\frac{n(n+1)}{12} \cdot\left|\begin{array}{cc}
2 & n(n+1) \\
1 & n^{2}(n+1)^{2}
\end{array}\right|=\frac{n^{2}(n+1)^{2}}{12} \cdot\left|\begin{array}{cc}
2 & 1 \\
1 & n(n+1)
\end{array}\right|=\frac{n^{2}(n+1)^{2}}{12} \cdot\left(2 n^{2}+2 n-1\right) \text {. }
\end{aligned}
$$

Tehát:

$$
S_{5}=1^{5}+2^{5}+3^{5}+\ldots+n^{5}=\frac{n^{2}(n+1)^{2}\left(2 n^{2}+2 n-1\right)}{12} .
$$

A módszerrel kissé hosszadalmas és „helyigényes” számításokkal ugyan, de előállíthatók az előzőleg már ismertetett eljárások segítségével levezetett összefüggések.

\section{$\underline{\text { 8. Megjegyzés }}$}

Létezik olyan eljárás, amelyben lineáris egyenletrendszer által határozzuk meg egy adott polinom együtthatóit, majd a kapott polinom határozott integrálját véve eljutunk a megfelelő formuláig ([20]), illetve van olyan is amikor az egyenletrendszer révén kiszámított együtthatók segítségével közvetlenül felírhatjuk n-nek azt a polinomját, amely a kívánt hatványösszegnek megfelelő összefüggést adja meg ([28]). 


\subsubsection{A módszer általánosítása számtani sorozatok esetére}

A továbbiakban bemutatjuk azt, hogy mi történik akkor, ha egy tetszőleges számtani sorozat egymást követő tagjaival dolgozunk.

Tekintsünk egy olyan $\left\{a_{n}\right\}_{n \geq 1}$ számtani sorozatot, melynek első eleme $a$, differenciája pedig $d$, ahol $a$ és $d$ valós számok. Vizsgáljuk meg, mit tudunk mondani a sorozat első $n$ tagja $p$-edik hatványainak összegéről, vagyis egy p-edrendű számtani sorozat egymást követő tagjainak összegéről!

\section{Legyen}

$$
S_{p}(a, d)=a_{1}^{p}+a_{2}^{p}+a_{3}^{p}+\ldots+a_{n}^{p}=\sum_{i=1}^{n} a_{i}^{p}=\sum_{i=1}^{n}[a+(i-1) \cdot d]^{p},
$$

ahol $p=0 ; 1 ; 2 ; \ldots$.

$S_{0}(a, d)$ kiszámításával ezúttal sem kell külön foglalkoznunk, hiszen könnyen belátható hogy $S_{0}(a, d)=n$.

Azzal az esettel, amikor $d=0$, azaz a sorozat állandó, szintén nem kell külön foglalkozni, hiszen ilyenkor $S_{p}(a, 0)=n \cdot a_{1}^{p}=n \cdot a^{p}$.

Legyen tehát $d \neq 0$. Az alábbi gondolatmenet megegyezik az $S_{p}$ kiszámítására az előzőekben, már részletesen bemutatott eljárással.

Tekintsük tehát az

$$
a_{i+1}^{k+1}=\left(a_{i}+d\right)^{k+1}=\left(\begin{array}{c}
k+1 \\
0
\end{array}\right) \cdot a_{i}^{k+1}+\left(\begin{array}{c}
k+1 \\
1
\end{array}\right) \cdot a_{i}^{k} \cdot d+\ldots+\left(\begin{array}{c}
k+1 \\
k
\end{array}\right) \cdot a_{i}^{1} \cdot d^{k}+\left(\begin{array}{c}
k+1 \\
k+1
\end{array}\right) \cdot d^{k+1}
$$

azonosságot, melyet átrendezve és felhasználva hogy $\left(\begin{array}{c}k+1 \\ 0\end{array}\right)=1$ kapjuk, hogy:

$$
a_{i+1}^{k+1}-a_{i}^{k+1}=\left(\begin{array}{c}
k+1 \\
1
\end{array}\right) \cdot a_{i}^{k} \cdot d+\left(\begin{array}{c}
k+1 \\
2
\end{array}\right) \cdot a_{i}^{k-1} \cdot d^{2}+\ldots+\left(\begin{array}{c}
k+1 \\
k
\end{array}\right) \cdot a_{i}^{1} \cdot d^{k}+\left(\begin{array}{c}
k+1 \\
k+1
\end{array}\right) \cdot d^{k+1},(4.2
$$

ahol $i=1,2, \ldots, n$ és $k$ tetszőleges természetes szám.

Ekkor

$$
\begin{aligned}
& \sum_{i=1}^{n}\left[a_{i+1}^{k+1}-a_{i}^{k+1}\right]=\sum_{i=1}^{n}\left[\left(\begin{array}{c}
k+1 \\
1
\end{array}\right) \cdot a_{i}^{k} \cdot d+\left(\begin{array}{c}
k+1 \\
2
\end{array}\right) \cdot a_{i}^{k-1} \cdot d^{2}+\ldots+\left(\begin{array}{c}
k+1 \\
k
\end{array}\right) \cdot a_{i}^{1} \cdot d^{k}+\left(\begin{array}{c}
k+1 \\
k+1
\end{array}\right) \cdot d^{k+1}\right]= \\
& =\left(\begin{array}{c}
k+1 \\
1
\end{array}\right) \cdot d \cdot \sum_{i=1}^{n} a_{i}^{k}+\left(\begin{array}{c}
k+1 \\
2
\end{array}\right) \cdot d^{2} \cdot \sum_{i=1}^{n} a_{i}^{k-1}+\ldots+\left(\begin{array}{c}
k+1 \\
k
\end{array}\right) \cdot d^{k} \cdot \sum_{i=1}^{n} a_{i}^{1}+\left(\begin{array}{c}
k+1 \\
k+1
\end{array}\right) \cdot d^{k+1} \cdot \sum_{i=0}^{n} 1 .
\end{aligned}
$$

A baloldalon egy teleszkópikus összeg található, amely az összevonások után $a_{n+1}^{k+1}-a_{1}^{k+1}=(a+n d)^{k+1}-a^{k+1}$ alakot ölt, vagyis

$$
(a+n d)^{k+1}-a^{k+1}=d \cdot\left(\begin{array}{c}
k+1 \\
1
\end{array}\right) \cdot S_{k}(a, d)+\ldots+d^{k} \cdot\left(\begin{array}{c}
k+1 \\
k
\end{array}\right) \cdot S_{1}(a, d)+d^{k+1} \cdot\left(\begin{array}{c}
k+1 \\
k+1
\end{array}\right) \cdot S_{0}(a, d) .
$$


Átrendezve a kapott egyenlőséget, felírható, hogy:

$$
\begin{aligned}
& (a+n d)^{k+1}-a^{k+1}= \\
& =\left(\begin{array}{c}
k+1 \\
k+1
\end{array}\right) \cdot S_{0}(a, d) \cdot d^{k+1}+\left(\begin{array}{c}
k+1 \\
k
\end{array}\right) \cdot S_{1}(a, d) \cdot d^{k}+\ldots+\left(\begin{array}{c}
k+1 \\
1
\end{array}\right) \cdot S_{k}(a, d) \cdot d
\end{aligned}
$$

Rendeljünk a (4.2.6) összefüggéshez egy lineáris egyenletrendszert, amelyet úgy kapunk, hogy $k$-nak rendre $0,1,2, \ldots, p$ értékeket adunk. Így az alábbi egyenletrendszerhez jutunk:

$$
\left\{\begin{array}{l}
(a+n d)^{1}-a^{1}=\left(\begin{array}{l}
1 \\
1
\end{array}\right) \cdot S_{0}(a, d) \cdot d \\
(a+n d)^{2}-a^{2}=\left(\begin{array}{l}
2 \\
2
\end{array}\right) \cdot S_{0}(a, d) \cdot d^{2}+\left(\begin{array}{l}
2 \\
1
\end{array}\right) \cdot S_{1}(a, d) \cdot d \\
(a+n d)^{3}-a^{3}=\left(\begin{array}{l}
3 \\
3
\end{array}\right) \cdot S_{0}(a, d) \cdot d^{3}+\left(\begin{array}{l}
3 \\
2
\end{array}\right) \cdot S_{1}(a, d) \cdot d^{2}+\left(\begin{array}{l}
3 \\
1
\end{array}\right) \cdot S_{2}(a, d) \cdot d \\
--------------------------------------- \\
(a+n d)^{p}-a^{p}=\left(\begin{array}{l}
p \\
p
\end{array}\right) \cdot S_{0}(a, d) \cdot d^{p}+\left(\begin{array}{c}
p \\
p-1
\end{array}\right) \cdot S_{1}(a, d) \cdot d^{p-1}+\ldots+\left(\begin{array}{c}
p \\
1
\end{array}\right) \cdot S_{p-1}(a, d) \cdot d \\
(a+n d)^{p+1}-a^{p+1}=\left(\begin{array}{c}
p+1 \\
p+1
\end{array}\right) \cdot S_{0}(a, d) \cdot d^{p+1}+\left(\begin{array}{c}
p+1 \\
p
\end{array}\right) \cdot S_{1}(a, d) \cdot d^{p}+\ldots+\left(\begin{array}{c}
p+1 \\
1
\end{array}\right) \cdot S_{p}(a, d) \cdot d
\end{array}\right.
$$

Az így kapott $(p+1)$ egyenletből álló egyenletrendszerben tekintsük ismeretleneknek az $S_{0}(a, d), S_{1}(a, d), S_{2}(a, d), \ldots, S_{p}(a, d) \quad$ „szimbólumokat”. $\quad \mathrm{Az} \quad$ egyenletrendszer együtthatómátrixának determinánsa:

$$
\begin{aligned}
& D^{\prime}=\left|\begin{array}{lccccc}
\left(\begin{array}{l}
1 \\
1
\end{array}\right) \cdot d & 0 & 0 & \ldots & 0 & 0 \\
\left(\begin{array}{l}
2 \\
2
\end{array}\right) \cdot d^{2} & \left(\begin{array}{l}
2 \\
1
\end{array}\right) \cdot d & 0 & \ldots & 0 & 0 \\
\left(\begin{array}{l}
3 \\
3
\end{array}\right) \cdot d^{3} & \left(\begin{array}{l}
3 \\
2
\end{array}\right) \cdot d^{2} & \left(\begin{array}{l}
3 \\
1
\end{array}\right) \cdot d & \ldots & 0 & 0 \\
\hdashline--- & --- & ---- & ---- & ---- & ---- \\
\left(\begin{array}{l}
p \\
p
\end{array}\right) \cdot d^{p} & \left(\begin{array}{c}
p \\
p-1
\end{array}\right) \cdot d^{p-1} & \left(\begin{array}{c}
p \\
p-2
\end{array}\right) \cdot d^{p-2} & \ldots & \left(\begin{array}{c}
p \\
1
\end{array}\right) \cdot d & 0 \\
\left(\begin{array}{l}
p+1 \\
p+1
\end{array}\right) \cdot d^{p+1} & \left(\begin{array}{c}
p+1 \\
p
\end{array}\right) \cdot d^{p} & \left(\begin{array}{c}
p+1 \\
p-1
\end{array}\right) \cdot d^{p-1} & \ldots & \left(\begin{array}{c}
p+1 \\
2
\end{array}\right) \cdot d^{2} & \left(\begin{array}{c}
p+1 \\
1
\end{array}\right) \cdot d
\end{array}\right|= \\
& =\left(\begin{array}{l}
1 \\
1
\end{array}\right) \cdot d \cdot\left(\begin{array}{l}
2 \\
1
\end{array}\right) \cdot d \cdot\left(\begin{array}{l}
3 \\
1
\end{array}\right) \cdot d \cdot \ldots \cdot\left(\begin{array}{l}
p \\
1
\end{array}\right) \cdot d \cdot\left(\begin{array}{c}
p+1 \\
1
\end{array}\right) \cdot d=(p+1) ! \cdot d^{p+1} \text {. }
\end{aligned}
$$

Mivel $D^{\prime}=(p+1) ! \cdot d^{p+1} \neq 0$, alkalmazható a Cramer-szabály. 
Az $S_{p}(a, d)$-nek megfelelő determináns:

$$
D_{p}^{\prime}=\left|\begin{array}{ccccc}
\left(\begin{array}{l}
1 \\
1
\end{array}\right) \cdot d & 0 & \ldots & 0 & (a+n d)^{1}-a^{1} \\
\left(\begin{array}{l}
2 \\
2
\end{array}\right) \cdot d^{2} & \left(\begin{array}{l}
2 \\
1
\end{array}\right) \cdot d & \ldots & 0 & (a+n d)^{2}-a^{2} \\
\left(\begin{array}{l}
3 \\
3
\end{array}\right) \cdot d^{3} & \left(\begin{array}{l}
3 \\
2
\end{array}\right) \cdot d^{2} & \ldots & 0 & (a+n d)^{3}-a^{3} \\
---- & ---- & --- & ----- & ----- \\
\left(\begin{array}{l}
p \\
p
\end{array}\right) \cdot d^{p} & \left(\begin{array}{c}
p \\
p-1
\end{array}\right) \cdot d^{p-1} & \cdots & \left(\begin{array}{c}
p \\
1
\end{array}\right) \cdot d & (a+n d)^{p}-a^{p} \\
\left(\begin{array}{l}
p+1 \\
p+1
\end{array}\right) \cdot d^{p+1} & \left(\begin{array}{c}
p+1 \\
p
\end{array}\right) \cdot d^{p} & \ldots & \left(\begin{array}{c}
p+1 \\
2
\end{array}\right) \cdot d^{2} & (a+n d)^{p+1}-a^{p+1}
\end{array}\right| .
$$

A Cramer-szabály alapján

$$
S_{p}(a, d)=\frac{D_{p}^{\prime}}{D^{\prime}}=\frac{1}{(p+1) ! d^{p+1}} \cdot D_{p}^{\prime},
$$

ahol $p=0 ; 1 ; 2 ; 3 ; \ldots$.

Jóllehet a (4.2.7) képlet talán egy kissé „ijesztőnek” tünik, azonban a konkrét számításokban könnyen és hatékonyan alkalmazható.

\section{Megjegyzés}

Az $S_{p}(a, d)$ kiszámítása a $p=2$ esetére, valamint négy speciális eset felírása megtalálható [26]-ban.

\subsubsection{A Bernoulli-számok megjelenése}

A Bernoulli-számok fontos szerepet játszanak többek között az analitikus számelméletben, a kombinatorikában és az approximációelméletben. Épp ezért meghatározásuk fontos matematikai számítási részterület. A hatványösszegek kiszámításánál alkalmazott lineáris algebrai módszer felhasználható a Bernoulli-számok meghatározásához. Ugyanis az első $n$ pozitív egész szám azonos hatványai összegének kiszámításánál felhasznált lineáris egyenletrendszerhez hasonló egyenletrendszer megoldására van szükségünk a Bernoulliszámok kiszámításához is.

\section{Definíció}

Tekintsük az $\frac{x}{e^{x}-1}$ függvény hatványsorba fejtését, vagyis:

$$
\frac{x}{e^{x}-1}=\sum_{k=0}^{\infty} \frac{B_{k}}{k !} \cdot x^{k}
$$

A hatványsor együtthatóiban szereplő $B_{k}-\mathrm{k}$ az úgynevezett Bernoulli-számok.

(lásd [4] 128-133. o.). 


\section{Definíció}

Az első $(p+1)$ Bernoulli-szám $\left(B_{0}, B_{1}, B_{2}, \ldots, B_{p}\right)$ értékét megkapjuk, ha megoldjuk az alábbi egyenletrendszert:

$$
\left\{\begin{array}{l}
1=\left(\begin{array}{l}
1 \\
1
\end{array}\right) \cdot B_{0} \\
0=\left(\begin{array}{l}
2 \\
2
\end{array}\right) \cdot B_{0}+\left(\begin{array}{l}
2 \\
1
\end{array}\right) \cdot B_{1} \\
0=\left(\begin{array}{l}
3 \\
3
\end{array}\right) \cdot B_{0}+\left(\begin{array}{l}
3 \\
2
\end{array}\right) \cdot B_{1}+\left(\begin{array}{l}
3 \\
1
\end{array}\right) \cdot B_{2} \\
-------------------------- \\
0=\left(\begin{array}{l}
p \\
p
\end{array}\right) \cdot B_{0}+\left(\begin{array}{c}
p \\
p-1
\end{array}\right) \cdot B_{1}+\left(\begin{array}{c}
p \\
p-2
\end{array}\right) \cdot B_{2}+\ldots+\left(\begin{array}{c}
p \\
2
\end{array}\right) \cdot B_{p-2}+\left(\begin{array}{c}
p \\
1
\end{array}\right) \cdot B_{p-1} \\
0=\left(\begin{array}{c}
p+1 \\
p+1
\end{array}\right) \cdot B_{0}+\left(\begin{array}{c}
p+1 \\
p
\end{array}\right) \cdot B_{1}+\left(\begin{array}{c}
p+1 \\
p-1
\end{array}\right) \cdot B_{2}+\ldots+\left(\begin{array}{c}
p+1 \\
2
\end{array}\right) \cdot B_{p-1}+\left(\begin{array}{c}
p+1 \\
1
\end{array}\right) \cdot B_{p} .
\end{array}\right.
$$

(lásd [11] 680-685. o.).

A (4.2.9) egyenletrendszerhez rendelt mátrix determinánsa megegyezik a összefüggések által felírt egyenletrendszernek megfelelö mátrix determinánsával, azaz

$$
\begin{aligned}
& D^{\prime \prime}=\left|\begin{array}{lccccc}
\left(\begin{array}{l}
1 \\
1
\end{array}\right) & 0 & 0 & \ldots & 0 & 0 \\
\left(\begin{array}{l}
2 \\
2
\end{array}\right) & \left(\begin{array}{l}
2 \\
1
\end{array}\right) & 0 & \ldots & 0 & 0 \\
\left(\begin{array}{l}
3 \\
3
\end{array}\right) & \left(\begin{array}{l}
3 \\
2
\end{array}\right) & \left(\begin{array}{l}
3 \\
1
\end{array}\right) & \ldots & 0 & 0 \\
\hdashline-- & --- & --- & --- & --- & --- \\
\left(\begin{array}{l}
p \\
p
\end{array}\right) & \left(\begin{array}{c}
p \\
p-1
\end{array}\right) & \left(\begin{array}{c}
p \\
p-2
\end{array}\right) & \ldots & \left(\begin{array}{c}
p \\
1
\end{array}\right) & 0 \\
\left(\begin{array}{l}
p+1 \\
p+1
\end{array}\right) & \left(\begin{array}{c}
p+1 \\
p
\end{array}\right) & \left(\begin{array}{c}
p+1 \\
p-1
\end{array}\right) & \cdots & \left(\begin{array}{c}
p+1 \\
2
\end{array}\right) & \left(\begin{array}{c}
p+1 \\
1
\end{array}\right)
\end{array}\right|= \\
& =\left(\begin{array}{l}
1 \\
1
\end{array}\right) \cdot\left(\begin{array}{l}
2 \\
1
\end{array}\right) \cdot\left(\begin{array}{l}
3 \\
1
\end{array}\right) \cdot \ldots \cdot\left(\begin{array}{l}
p \\
1
\end{array}\right) \cdot\left(\begin{array}{c}
p+1 \\
1
\end{array}\right)=(p+1) ! .
\end{aligned}
$$

Mivel $D^{\prime \prime}=(p+1) ! \neq 0$, alkalmazható a Cramer-szabály. 
A $B_{p}$-nek megfelelő determináns:

$$
D_{p}^{\prime \prime}=\left|\begin{array}{lccccc}
\left(\begin{array}{l}
1 \\
1
\end{array}\right) & 0 & 0 & \ldots & 0 & 1 \\
\left(\begin{array}{l}
2 \\
2
\end{array}\right) & \left(\begin{array}{l}
2 \\
1
\end{array}\right) & 0 & \ldots & 0 & 0 \\
\left(\begin{array}{l}
3 \\
3
\end{array}\right) & \left(\begin{array}{l}
3 \\
2
\end{array}\right) & \left(\begin{array}{l}
3 \\
1
\end{array}\right) & \cdots & 0 & 0 \\
--- & --- & --- & --- & --- & --- \\
\left(\begin{array}{c}
p \\
p
\end{array}\right) & \left(\begin{array}{c}
p \\
p-1
\end{array}\right) & \left(\begin{array}{c}
p \\
p-2
\end{array}\right) & \cdots & \left(\begin{array}{c}
p \\
1
\end{array}\right) & 0 \\
\left(\begin{array}{l}
p+1 \\
p+1
\end{array}\right) & \left(\begin{array}{c}
p+1 \\
p
\end{array}\right) & \left(\begin{array}{c}
p+1 \\
p-1
\end{array}\right) & \cdots & \left(\begin{array}{c}
p+1 \\
2
\end{array}\right) & 0
\end{array}\right| .
$$

Így a Cramer-szabály szerint:

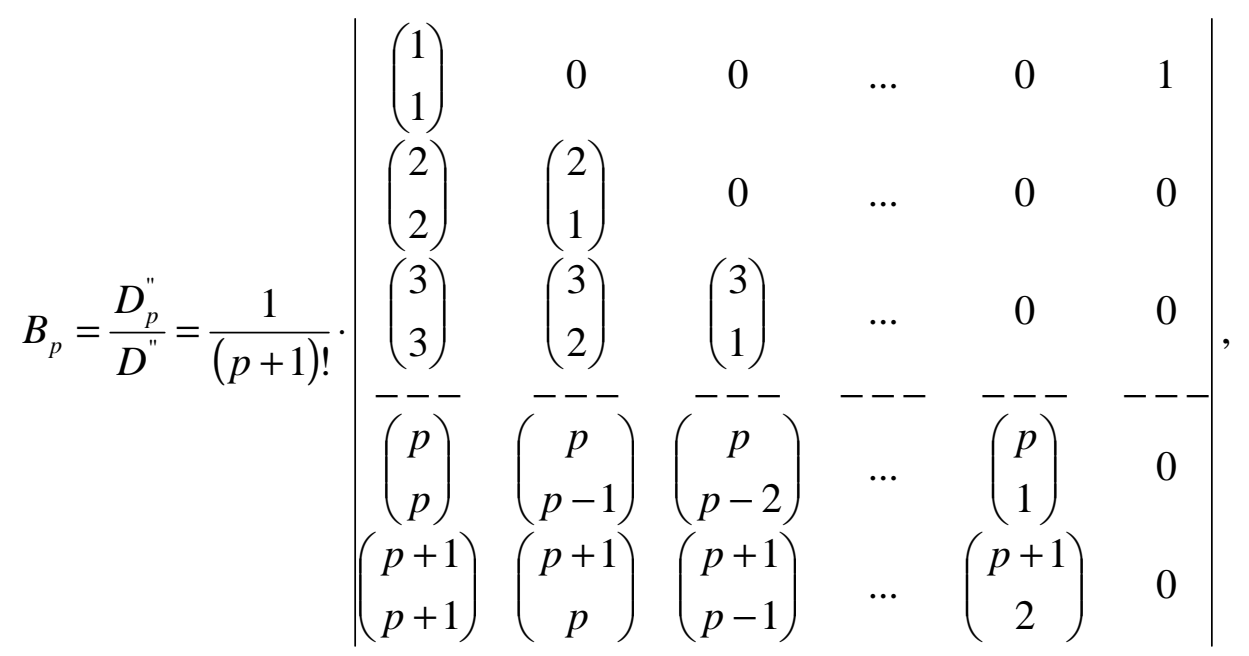

ahol $p=0 ; 1 ; 2 ; 3 ; \ldots$ (a $B_{0}$ kiszámításával külön nem kell foglalkoznunk, hiszen az első egyenletböl azonnal következik, hogy $B_{0}=1$ ).

Példaként lássuk két konkrét esetben a megfelelő Bernoulli-szám kiszámítását, jelesül számítsuk ki $B_{4}$ és $B_{5}$ értékét!

$$
\begin{aligned}
& \left|\begin{array}{lcccc}
\left(\begin{array}{l}
1 \\
1
\end{array}\right) & 0 & 0 & 0 & 1 \\
\left(\begin{array}{l}
2 \\
2
\end{array}\right) & \left(\begin{array}{l}
2 \\
1
\end{array}\right) & 0 & 0 & 0
\end{array}\right| \\
& B_{4}=\frac{1}{5 !} \cdot\left(\begin{array}{l}
3 \\
3
\end{array}\right)\left(\begin{array}{l}
3 \\
2
\end{array}\right) \quad\left(\begin{array}{l}
3 \\
1
\end{array}\right) \quad 0 \quad 0 \quad=\frac{1}{120} \cdot\left|\begin{array}{llll}
1 & 2 & 0 & 0 \\
1 & 3 & 3 & 0 \\
1 & 4 & 6 & 4
\end{array}\right|=\frac{1}{120} \cdot\left|\begin{array}{llll}
1 & 2 & 0 & 0 \\
0 & 1 & 3 & 0 \\
0 & 2 & 6 & 4
\end{array}\right|= \\
& \left(\begin{array}{l}
4 \\
4
\end{array}\right)\left(\begin{array}{l}
4 \\
3
\end{array}\right)\left(\begin{array}{l}
4 \\
2
\end{array}\right)\left(\begin{array}{l}
4 \\
1
\end{array}\right) \quad 0 \quad\left[\begin{array}{llcc}
1 & 5 & 10 & 10
\end{array}|\quad| \begin{array}{llcc}
0 & 3 & 10 & 10
\end{array} \mid\right. \\
& \left(\begin{array}{l}
5 \\
5
\end{array}\right)\left(\begin{array}{l}
5 \\
4
\end{array}\right)\left(\begin{array}{l}
5 \\
3
\end{array}\right)\left(\begin{array}{l}
5 \\
2
\end{array}\right) \quad 0
\end{aligned}
$$


$=\frac{1}{120} \cdot\left|\begin{array}{ccc}1 & 3 & 0 \\ 2 & 6 & 4 \\ 3 & 10 & 10\end{array}\right|=\frac{1}{120} \cdot\left|\begin{array}{ccc}1 & 0 & 0 \\ 2 & 0 & 4 \\ 3 & 1 & 10\end{array}\right|=\frac{1}{120} \cdot\left|\begin{array}{cc}0 & 4 \\ 1 & 10\end{array}\right|=\frac{1}{120} \cdot(0-4)=-\frac{1}{30}$.

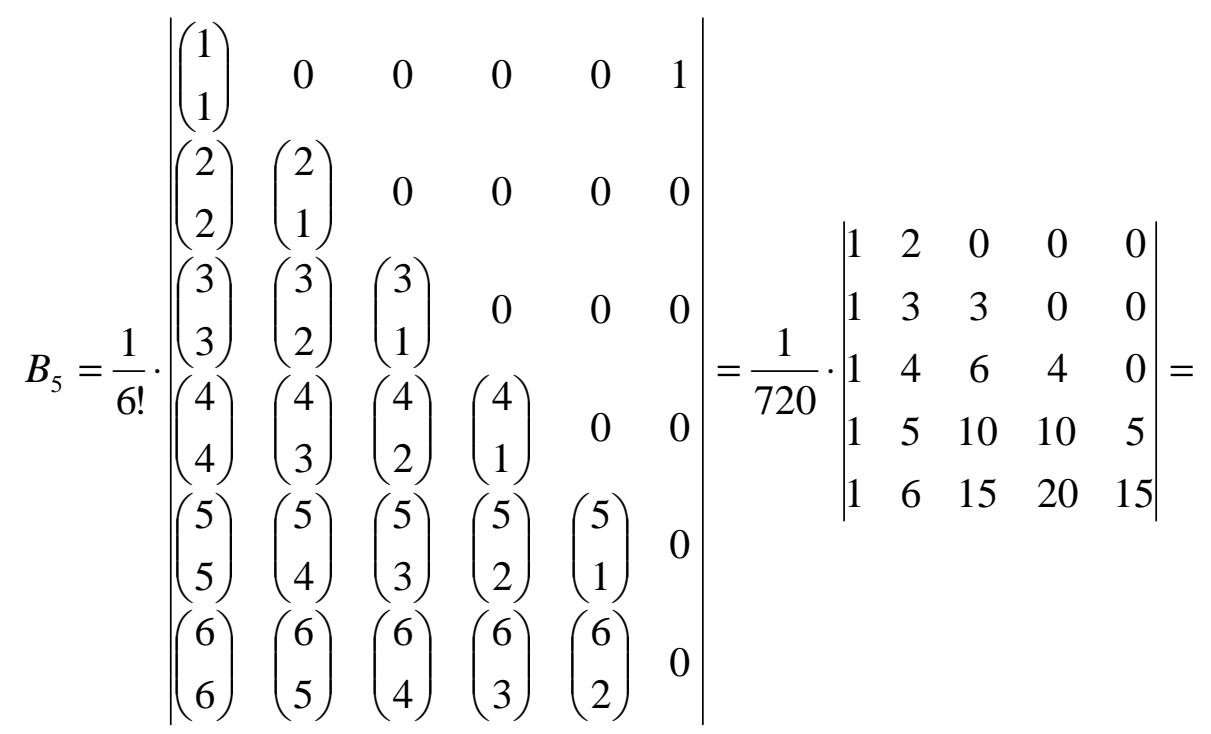

$=\frac{1}{720} \cdot\left|\begin{array}{ccccc}1 & 2 & 0 & 0 & 0 \\ 0 & 1 & 3 & 0 & 0 \\ 0 & 2 & 6 & 4 & 0 \\ 0 & 3 & 10 & 10 & 5 \\ 0 & 4 & 15 & 20 & 15\end{array}\right|=\frac{1}{720} \cdot\left|\begin{array}{cccc}1 & 3 & 0 & 0 \\ 2 & 6 & 4 & 0 \\ 3 & 10 & 10 & 5 \\ 4 & 15 & 20 & 15\end{array}\right|=\frac{1}{720} \cdot\left|\begin{array}{cccc}1 & 0 & 0 & 0 \\ 2 & 0 & 4 & 0 \\ 3 & 1 & 10 & 5 \\ 4 & 3 & 20 & 15\end{array}\right|=0$,

ugyanis az utolsó determináns második és negyedik oszlopa arányos.

Az első néhány Bernoulli-szám értéke:

$B_{0}=1 ; B_{1}=-\frac{1}{2} ; B_{2}=\frac{1}{6} ; B_{3}=0 ; B_{4}=-\frac{1}{30} ; B_{5}=0 ; B_{6}=\frac{1}{42} ; B_{7}=0 ; B_{8}=-\frac{1}{30}$.

Úgy tünik, hogy a páratlan indexü Bernoulli-számok, az első kivételével mind nullák.

Bebizonyítható, hogy ez az állítás igaz.

2. Tétel

A $B_{1}$ kivételével minden páratlan indexü Bernoulli-szám 0.

Bizonyítás:

Mivel

$\frac{x}{e^{x}-1}+\frac{x}{2}=\frac{1}{2} \cdot \frac{x\left(e^{x}+1\right)}{e^{x}-1}=\frac{1}{2} \cdot \frac{x \cdot e^{x} \cdot\left(1+\frac{1}{e^{x}}\right)}{e^{x} \cdot\left(1-\frac{1}{e^{x}}\right)}=\frac{1}{2} \cdot \frac{x\left(1+e^{-x}\right)}{1-e^{-x}}=\frac{1}{2} \cdot \frac{-x\left(1+e^{-x}\right)}{e^{-x}-1}$,

ezáltal belátható, hogy az $\frac{x}{e^{x}-1}+\frac{x}{2}$ függvény páros. 
A 2. Definíció alapján az $\frac{x}{e^{x}-1}=\sum_{k=0}^{\infty} \frac{B_{k}}{k !} \cdot x^{k}$, melyet kifejtve kapjuk hogy $\frac{x}{e^{x}-1}+\frac{x}{2}=B_{0}+\left(B_{1}+\frac{1}{2}\right) \cdot \frac{x}{1 !}+B_{2} \cdot \frac{x^{2}}{2 !}+B_{3} \cdot \frac{x^{3}}{3 !}+B_{4} \cdot \frac{x^{4}}{4 !}+B_{5} \cdot \frac{x^{5}}{5 !}+B_{6} \cdot \frac{x^{6}}{6 !}+\ldots$.

Felhasználva az $\frac{x}{e^{x}-1}+\frac{x}{2}$ függvény páros voltát kapjuk, hogy a páratlan fokszámú tagok együtthatói mind zérók, azaz $B_{1}+\frac{1}{2}=B_{3}=B_{5}=B_{7}=\ldots=0$.

Q.e.d.

A $B_{p}$-nek létezik másik determináns segítségével felírt alakja is ([45]), azonban bebizonyítható, hogy a két felírás egyenértékü.

\section{Tétel}

$$
B_{p}=\frac{1}{p_{i}} \cdot\left|\begin{array}{cccccc}
1 i & 0 & 0 & \ldots & 0 & 1 \\
2 i & 1 i & 0 & \ldots & 0 & 0 \\
3 i & 2 i & 1 i & \ldots & 0 & 0 \\
--- & --- & --- & --- & --- & ---- \\
p_{i} & (p-1)_{i} & (p-2)_{i} & \ldots & 2 i & 0 \\
(p+1)_{i} & p_{i} & (p-1)_{i} & \ldots & 1 i & 0
\end{array}\right|
$$

ahol $n_{i}$ az $n$ ! reciprokát jelöli, azaz $n_{i}=\frac{1}{n !}$.

Bizonyítás:

Induljunk ki a (4.2.10) összefüggésből:

$B_{p}=\frac{1}{(p+1) !} \cdot\left|\begin{array}{cccccc}\left(\begin{array}{l}1 \\ 1\end{array}\right) & 0 & 0 & \ldots & 0 & 1 \\ \left(\begin{array}{l}2 \\ 2\end{array}\right) & \left(\begin{array}{l}2 \\ 1\end{array}\right) & 0 & \ldots & 0 & 0 \\ \left(\begin{array}{l}3 \\ 3\end{array}\right) & \left(\begin{array}{l}3 \\ 2\end{array}\right) & \left(\begin{array}{l}3 \\ 1\end{array}\right) & \ldots & 0 & 0 \\ --- & --- & --- & --- & --- & --- \\ \left(\begin{array}{l}p \\ p\end{array}\right) & \left(\begin{array}{c}p \\ p-1\end{array}\right) & \left(\begin{array}{c}p \\ p-2\end{array}\right) & \ldots & \left(\begin{array}{c}p \\ 1\end{array}\right) & 0 \\ \left(\begin{array}{l}p+1 \\ p+1\end{array}\right) & \left(\begin{array}{c}p+1 \\ p\end{array}\right) & \left(\begin{array}{c}p+1 \\ p-1\end{array}\right) & \ldots & \left(\begin{array}{c}p+1 \\ 2\end{array}\right) & 0\end{array}\right|=$ 


$$
=\frac{1}{(p+1) !} \cdot\left|\begin{array}{cccccc}
\frac{1 !}{1 ! \cdot 0 !} & 0 & 0 & \ldots & 0 & 1 \\
\frac{2 !}{2 ! \cdot 0 !} & \frac{2 !}{1 ! \cdot 1 !} & 0 & \ldots & 0 & 0 \\
\frac{3 !}{3 ! \cdot 0 !} & \frac{3 !}{2 ! \cdot 1 !} & \frac{3 !}{1 ! \cdot 2 !} & \ldots & 0 & 0 \\
--- & --- & --- & --- & --- & --- \\
\frac{p !}{p ! \cdot 0 !} & \frac{p !}{(p-1) ! \cdot 1 !} & \frac{p !}{(p-2) ! \cdot 2 !} & \ldots & \frac{p !}{1 ! \cdot(p-1) !} & 0 \\
\frac{(p+1) !}{(p+1) ! \cdot 0 !} & \frac{(p+1) !}{p ! \cdot 1 !} & \frac{(p+1) !}{(p-1) ! \cdot 2 !} & \ldots & \frac{(p+1) !}{2 ! \cdot(p-1) !} & 0
\end{array}\right| .
$$

Minden sorból és minden oszlopból - az utolsó kivételével - emeljünk ki a következőképpen: az $i$-edik sorból emeljünk ki $i$--t, ahol $i=1,2,3, \ldots,(p+1)$, a j-edik oszlopból pedig $\frac{1}{(j-1) !}$-t, ahol $j=1,2,3, \ldots, p$.

Így adódik, hogy:

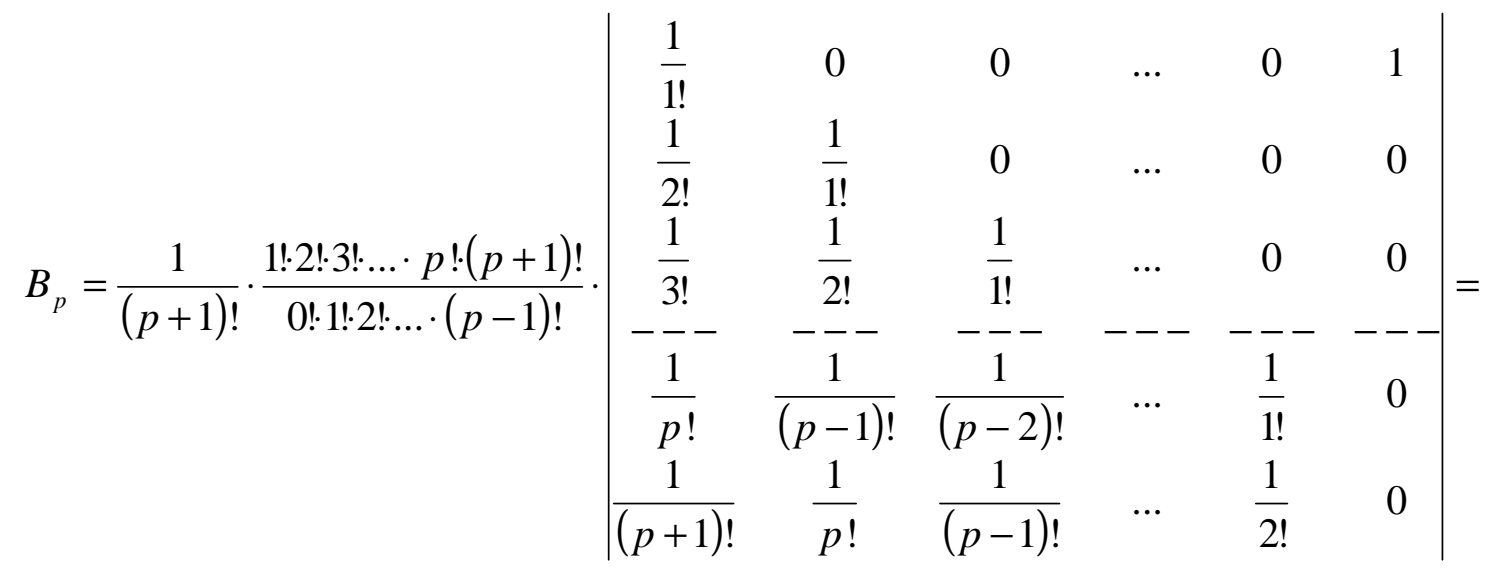

$$
\begin{aligned}
& =\frac{p !}{0 !} \cdot\left|\begin{array}{cccccc}
1 i & 0 & 0 & \ldots & 0 & 1 \\
2 i & 1 i & 0 & \ldots & 0 & 0 \\
3 i & 2 i & 1 i & \ldots & 0 & 0 \\
--- & --- & --- & --- & --- & --- \\
p_{i} & (p-1) i & (p-2) i & \ldots & 2 i & 0 \\
(p+1)_{i} & p_{i} & (p-1)_{i} & \ldots & 1 i & 0
\end{array}\right|= \\
& =\frac{1}{p_{i}} \cdot\left|\begin{array}{cccccc}
1_{i} & 0 & 0 & \ldots & 0 & 1 \\
2 i & 1 i & 0 & \ldots & 0 & 0 \\
3 i & 2 i & 1 i & \ldots & 0 & 0 \\
--- & --- & --- & --- & --- & ---- \\
p_{i} & (p-1)_{i} & (p-2)_{i} & \ldots & 2 i & 0 \\
(p+1)_{i} & p_{i} & (p-1)_{i} & \ldots & 1 i & 0
\end{array}\right|,
\end{aligned}
$$

ahol felhasználtuk, hogy $0 !=1$ és azt, hogy az $n_{i}=\frac{1}{n !}$ jelölést vezettük be.

Q.e.d. 


\section{Megjegyzés}

A Bernoulli-számok között különböző rekurziós összefüggések állíthatók fel (lásd [45]). A teljesség igénye nélkül néhány példa:

Ha $n \geq 1$, akkor teljesülnek
1) $\frac{1}{n} \cdot \sum_{k=1}^{n}\left(\begin{array}{l}n \\ k\end{array}\right) \cdot B_{k} \cdot B_{n-k}+B_{n-1}=-B_{n} \quad$ (Euler)
2) $\sum_{k=0}^{n}\left(\begin{array}{c}n+1 \\ k\end{array}\right) \cdot(n+k+1) \cdot B_{n+k}=0 \quad$ (von Ettingshausen)
3) $B_{n}=-\sum_{k=1}^{n+1} \frac{(-1)^{k}}{k} \cdot\left(\begin{array}{c}n+1 \\ k\end{array}\right) \cdot \sum_{j=1}^{n} j^{n} \quad$ (Kronecker)
4) $\sum_{k=0}^{n}\left(\begin{array}{l}n \\ k\end{array}\right) \cdot \frac{B_{k}}{n-k+2}=\frac{B_{n+1}}{n+1}$.

\subsubsection{A Stirling- és Bernoulli-számok közötti kapcsolat}

A 3.4.3. fejezetben definiált Stirling-féle számok és a Bernoulli-számok között kapcsolat teremthető (lásd [18], [45]), éspedig:

ha $n \geq 0$, akkor teljesülnek a következők:

$$
B_{n}=\sum_{k=0}^{n}(-1)^{k} \cdot \frac{k !}{k+1} \cdot S(n+1, k+1),
$$

illetve

$$
\sum_{k=0}^{n}(-1)^{k} \cdot s(n+1, k+1) \cdot B_{k}=\frac{n !}{n+1},
$$

ahol $S(n, k)$ a másodfajú Stirling-számot, míg $s(n, k)$ az elsőfajú Stirling-számot jelöli, azzal a megjegyzéssel, hogy ez utóbbi összefüggés $B_{1}=\frac{1}{2}$-et ad eredményül.

Létezik más összefüggés is az elsőfajú Stirling-számok és a Bernoulli-számok között, éspedig:

ha $n \geq 0$ és $m \geq 0$, akkor

$$
\frac{1}{m !} \cdot \sum_{k=0}^{m}(-1)^{k} \cdot s(m+1, k+1) \cdot B_{n+k}=A_{n, m},
$$

ahol $A_{n, m}$ az ún. Akiyama-Tanigawa szám (lásd [16], [18], [45]).

Az Akiyama-Tanigawa számokat a következő rekurzióval kapjuk:

$$
A_{0, m}=\frac{1}{m+1} \text { és } A_{n+1, m}=(m+1) \cdot\left(A_{n, m}-A_{n, m+1}\right),
$$

ahol $n, m \in N$. 
Az első néhány Akiyama-Tanigawa szám a 4.2.1. táblázatban látható:

\begin{tabular}{|c|c|c|c|c|}
\hline$n \backslash m$ & 0 & 1 & 2 & 3 \\
\hline 0 & 1 & $\frac{1}{2}$ & $\frac{1}{3}$ & $\frac{1}{4}$ \\
\hline 1 & $\frac{1}{2}$ & $\frac{1}{3}$ & $\frac{1}{4}$ & $\frac{1}{5}$ \\
\hline 2 & $\frac{1}{6}$ & $\frac{1}{6}$ & $\frac{3}{20}$ & $\frac{2}{15}$ \\
\hline 3 & 0 & $\frac{1}{30}$ & $\frac{1}{20}$ & $\frac{2}{35}$ \\
\hline 4 & $-\frac{1}{30}$ & $-\frac{1}{30}$ & $-\frac{3}{140}$ & $-\frac{1}{105}$ \\
\hline 5 & 0 & $-\frac{1}{42}$ & $-\frac{1}{28}$ & $-\frac{4}{105}$ \\
\hline 6 & $\frac{1}{42}$ & $\frac{1}{42}$ & $\frac{1}{140}$ & $-\frac{1}{105}$ \\
\hline
\end{tabular}

4.2.1. táblázat Az első néhány Akiyama-Tanigawa szám

Az adott (4.2.15) rekurzió segítségével előállított számok közül az $A_{n, 0}$-k pontosan a $B_{n}-\mathrm{t}$ adják eredményül, azzal a megjegyzéssel, hogy akárcsak a (4.2.13) esetén ebben az esetben is a $B_{1}$ értéke $\frac{1}{2}$ lesz.

\subsubsection{Kapcsolat az első $n$ pozitív egész szám $p$-edik hatványának összege és a Bernoulli-számok között}

A következő állítás kapcsolatot teremt az $S_{p}$ és a Bernoulli-számok között.

\section{Tétel (Jakob Bernoulli)}

Az első $n$ pozitív egész szám $p$-edik $(p \geq 1)$ hatványának összege előállítható a következőképpen:

$$
S_{p}=\sum_{i=1}^{n} i^{p}=\frac{1}{p+1} \cdot \sum_{k=0}^{p}\left(\begin{array}{c}
p+1 \\
k
\end{array}\right) \cdot B_{k} \cdot(n+1)^{p+1-k} .
$$

Bizonyítás:

A bizonyítás $p$ szerinti teljes indukcióval történik.

Legyen $p=1$.

$$
\begin{aligned}
& S_{1}=\frac{1}{2} \cdot \sum_{k=0}^{1}\left(\begin{array}{l}
2 \\
k
\end{array}\right) \cdot B_{k} \cdot(n+1)^{2-k}=\frac{1}{2} \cdot\left[\left(\begin{array}{l}
2 \\
0
\end{array}\right) \cdot 1 \cdot(n+1)^{2}+\left(\begin{array}{l}
2 \\
1
\end{array}\right) \cdot\left(-\frac{1}{2}\right) \cdot(n+1)\right]= \\
& =\frac{n+1}{2} \cdot(n+1-1)=\frac{n(n+1)}{2} .
\end{aligned}
$$


Tehát az állítás $p=1$ esetén igaz.

Tegyük fel, hogy az állítás igaz minden $1 \leq k \leq p-1$ esetén. Bizonyítandó, hogy a $k=p$ esetben is igaz.

Legyen $T_{j}=\frac{1}{j+1} \cdot \sum_{k=0}^{j}\left(\begin{array}{c}j+1 \\ k\end{array}\right) \cdot B_{k} \cdot(n+1)^{j+1-k}$, ahol $1 \leq j \leq p$, és legyen $\Delta=T_{p}-S_{p}$.

A $T_{j}$ definíciója alapján következik, hogy $S_{j}=T_{j}$ minden $1 \leq j \leq p-1$ esetén. Azt kell bizonyítanunk, hogy $S_{p}=T_{p}$.

Mindezek alapján, felhasználva a $\Delta$ definícióját:

$$
\begin{aligned}
& \sum_{j=1}^{p}\left(\begin{array}{c}
p+1 \\
j
\end{array}\right) \cdot S_{j}=\sum_{j=1}^{p-1}\left(\begin{array}{c}
p+1 \\
j
\end{array}\right) \cdot S_{j}+\left(\begin{array}{c}
p+1 \\
p
\end{array}\right) \cdot S_{p}=\sum_{j=1}^{p-1}\left(\begin{array}{c}
p+1 \\
j
\end{array}\right) \cdot T_{j}+\left(\begin{array}{c}
p+1 \\
p
\end{array}\right) \cdot\left(T_{p}+\Delta\right)= \\
& =\sum_{j=1}^{p-1}\left(\begin{array}{c}
p+1 \\
j
\end{array}\right) \cdot T_{j}+\left(\begin{array}{c}
p+1 \\
p
\end{array}\right) \cdot T_{p}+\left(\begin{array}{c}
p+1 \\
p
\end{array}\right) \cdot \Delta=\sum_{j=1}^{p}\left(\begin{array}{c}
p+1 \\
j
\end{array}\right) \cdot T_{j}+(p+1) \cdot \Delta .
\end{aligned}
$$

Tehát:

$$
\sum_{j=1}^{p}\left(\begin{array}{c}
p+1 \\
j
\end{array}\right) \cdot S_{j}=\sum_{j=1}^{p}\left(\begin{array}{c}
p+1 \\
j
\end{array}\right) \cdot T_{j}+(p+1) \cdot \Delta .
$$

A kívánt $S_{p}=T_{p}$ egyenlőséget megkapjuk, ha sikerül bebizonyítani, hogy $\Delta=0$. Ehhez előbb a $\sum_{j=1}^{p}\left(\begin{array}{c}p+1 \\ j\end{array}\right) \cdot T_{j}$ kifejezést fogjuk egyszerübb alakra hozni.

A $T_{j}$ definíciója alapján:

$$
\begin{aligned}
& \sum_{j=1}^{p}\left(\begin{array}{c}
p+1 \\
j
\end{array}\right) \cdot T_{j}=\sum_{j=1}^{p}\left(\begin{array}{c}
p+1 \\
j
\end{array}\right) \cdot \frac{1}{j+1} \cdot \sum_{k=0}^{j}\left(\begin{array}{c}
j+1 \\
k
\end{array}\right) \cdot B_{k} \cdot(n+1)^{j+1-k}= \\
& =\sum_{j=1}^{p}\left(\begin{array}{c}
p+1 \\
j
\end{array}\right) \cdot \frac{1}{j+1} \cdot \sum_{k=0}^{j}\left(\begin{array}{c}
j+1 \\
j-k
\end{array}\right) \cdot B_{j-k} \cdot(n+1)^{k+1}=\sum_{j=1}^{p}\left(\begin{array}{c}
p+1 \\
j
\end{array}\right) \cdot \sum_{k=0}^{j} \frac{1}{j+1} \cdot\left(\begin{array}{c}
j+1 \\
j-k
\end{array}\right) \cdot B_{j-k} \cdot(n+1)^{k+1},
\end{aligned}
$$

ahol mivel véges sok tagból álló összegekről van szó, felcserélhettük az összegen belül az összegzés sorrendjét.

Így

$$
\sum_{j=1}^{p}\left(\begin{array}{c}
p+1 \\
j
\end{array}\right) \cdot T_{j}=\sum_{j=1}^{p}\left(\begin{array}{c}
p+1 \\
j
\end{array}\right) \cdot \sum_{k=0}^{j} \frac{1}{j+1} \cdot\left(\begin{array}{c}
j+1 \\
j-k
\end{array}\right) \cdot B_{j-k} \cdot(n+1)^{k+1} .
$$

Figyelembe véve, hogy

$$
\frac{1}{j+1} \cdot\left(\begin{array}{l}
j+1 \\
j-k
\end{array}\right)=\frac{1}{j+1} \cdot \frac{(j+1) !}{(j-k) ! \cdot(k+1) !}=\frac{j !}{(j-k) ! \cdot(k+1) !}=\frac{j !}{(j-k) ! k !} \cdot \frac{1}{k+1}=\frac{1}{k+1} \cdot\left(\begin{array}{l}
j \\
k
\end{array}\right),
$$


a (4.2.18) összefüggés alapján:

$$
\begin{aligned}
& \sum_{j=1}^{p}\left(\begin{array}{c}
p+1 \\
j
\end{array}\right) \cdot \sum_{k=0}^{j} \frac{1}{j+1} \cdot\left(\begin{array}{c}
j+1 \\
j-k
\end{array}\right) \cdot B_{j-k} \cdot(n+1)^{k+1}=\sum_{j=1}^{p}\left(\begin{array}{c}
p+1 \\
j
\end{array}\right) \cdot \sum_{k=0}^{j} \frac{1}{k+1} \cdot\left(\begin{array}{l}
j \\
k
\end{array}\right) \cdot B_{j-k} \cdot(n+1)^{k+1}= \\
& =\sum_{j=1}^{p} \sum_{k=0}^{j}\left(\begin{array}{c}
p+1 \\
j
\end{array}\right) \cdot \frac{1}{k+1} \cdot\left(\begin{array}{l}
j \\
k
\end{array}\right) \cdot B_{j-k} \cdot(n+1)^{k+1},
\end{aligned}
$$

vagyis

$$
\sum_{j=1}^{p}\left(\begin{array}{c}
p+1 \\
j
\end{array}\right) \cdot T_{j}=\sum_{j=1}^{p} \sum_{k=0}^{j}\left(\begin{array}{c}
p+1 \\
j
\end{array}\right) \cdot \frac{1}{k+1} \cdot\left(\begin{array}{l}
j \\
k
\end{array}\right) \cdot B_{j-k} \cdot(n+1)^{k+1} .
$$

Mivel $0 \leq k \leq j \leq p$, ezért ha vesszük $k$ és $j$ összes lehetséges párosítását az adott feltétel mellett, akkor a (4.2.19) összefüggés jobb oldalán álló összeg átírható a következő alakra:

$$
\begin{aligned}
& \sum_{j=1}^{p} \sum_{k=0}^{j}\left(\begin{array}{c}
p+1 \\
j
\end{array}\right) \cdot \frac{1}{k+1} \cdot\left(\begin{array}{l}
j \\
k
\end{array}\right) \cdot B_{j-k} \cdot(n+1)^{k+1}= \\
= & \sum_{k=0}^{p} \sum_{j=k}^{p}\left(\begin{array}{c}
p+1 \\
j
\end{array}\right) \cdot\left(\begin{array}{l}
j \\
k
\end{array}\right) \cdot \frac{1}{k+1} \cdot B_{j-k} \cdot(n+1)^{k+1}-\left(\begin{array}{c}
p+1 \\
0
\end{array}\right) \cdot\left(\begin{array}{l}
0 \\
0
\end{array}\right) \cdot \frac{1}{1} \cdot B_{0} \cdot(n+1)= \\
= & \sum_{k=0}^{p} \sum_{j=k}^{p}\left(\begin{array}{c}
p+1 \\
j
\end{array}\right) \cdot\left(\begin{array}{l}
j \\
k
\end{array}\right) \cdot \frac{1}{k+1} \cdot B_{j-k} \cdot(n+1)^{k+1}-(n+1)= \\
= & \sum_{k=0}^{p} \frac{(n+1)^{k+1}}{k+1} \cdot \sum_{j=k}^{p}\left(\begin{array}{c}
p+1 \\
j
\end{array}\right) \cdot\left(\begin{array}{l}
j \\
k
\end{array}\right) \cdot B_{j-k}-(n+1),
\end{aligned}
$$

ahol a kivonandó mennyiség a $k=0 ; j=0$ párosítás hiánya miatt jelentkezik.

Mindezeket felhasználva a (4.2.19) összefüggés alapján:

$$
\sum_{j=1}^{p}\left(\begin{array}{c}
p+1 \\
j
\end{array}\right) \cdot T_{j}=\sum_{k=0}^{p} \frac{(n+1)^{k+1}}{k+1} \cdot \sum_{j=k}^{p}\left(\begin{array}{c}
p+1 \\
j
\end{array}\right) \cdot\left(\begin{array}{l}
j \\
k
\end{array}\right) \cdot B_{j-k}-(n+1) .
$$

Továbbá az is felírható, hogy

$$
\begin{aligned}
& \left(\begin{array}{c}
p+1 \\
j
\end{array}\right) \cdot\left(\begin{array}{l}
j \\
k
\end{array}\right)=\frac{(p+1) !}{j ! \cdot(p+1-j) !} \cdot \frac{j !}{k ! \cdot(j-k) !}=\frac{(p+1) !}{(p+1-j) ! k ! \cdot(j-k) !}= \\
& =\frac{(p+1) !}{k ! \cdot(p+1-k) !} \cdot \frac{(p+1-k) !}{(p+1-j) ! \cdot(j-k) !}=\left(\begin{array}{c}
p+1 \\
k
\end{array}\right) \cdot\left(\begin{array}{c}
p+1-k \\
j-k
\end{array}\right),
\end{aligned}
$$

és így

$$
\begin{aligned}
& \sum_{k=0}^{p} \frac{(n+1)^{k+1}}{k+1} \cdot \sum_{j=k}^{p}\left(\begin{array}{c}
p+1 \\
j
\end{array}\right) \cdot\left(\begin{array}{l}
j \\
k
\end{array}\right) \cdot B_{j-k}-(n+1)= \\
& =\sum_{k=0}^{p} \frac{(n+1)^{k+1}}{k+1} \cdot \sum_{j=k}^{p}\left(\begin{array}{c}
p+1 \\
k
\end{array}\right) \cdot\left(\begin{array}{c}
p+1-k \\
j-k
\end{array}\right) \cdot B_{j-k}-(n+1)= \\
& =\sum_{k=0}^{p} \frac{(n+1)^{k+1}}{k+1} \cdot\left(\begin{array}{c}
p+1 \\
k
\end{array}\right) \cdot \sum_{j=k}^{p}\left(\begin{array}{c}
p+1-k \\
j-k
\end{array}\right) \cdot B_{j-k}-(n+1)=
\end{aligned}
$$


$=\sum_{k=0}^{p} \frac{(n+1)^{k+1}}{k+1} \cdot\left(\begin{array}{c}p+1 \\ k\end{array}\right) \cdot \sum_{j=0}^{p-k}\left(\begin{array}{c}p+1-k \\ j\end{array}\right) \cdot B_{j}-(n+1)$,

ahol felhasználtuk, hogy teljesül a $\sum_{j=k}^{p}\left(\begin{array}{c}p+1-k \\ j-k\end{array}\right) \cdot B_{j-k}=\sum_{j=0}^{p-k}\left(\begin{array}{c}p+1-k \\ j\end{array}\right) \cdot B_{j}$ egyenlőség.

Tehát:

$$
\sum_{j=1}^{p}\left(\begin{array}{c}
p+1 \\
j
\end{array}\right) \cdot T_{j}=\sum_{k=0}^{p} \frac{(n+1)^{k+1}}{k+1} \cdot\left(\begin{array}{c}
p+1 \\
k
\end{array}\right) \cdot \sum_{j=0}^{p-k}\left(\begin{array}{c}
p+1-k \\
j
\end{array}\right) \cdot B_{j}-(n+1) .
$$

A Bernoulli számok definíciójából következik, hogy $\sum_{j=0}^{p}\left(\begin{array}{c}p+1 \\ j\end{array}\right) \cdot B_{j}=0$ (kivéve, ha $p=0$ ).

Ez alapján a (4.2.21) összefüggés jobb oldalán található összegben minden tag „eltűnik”, kivéve a $p-k=0$, azaz $k=p$ esetet.

Tehát:

$$
\begin{aligned}
& \sum_{j=1}^{p}\left(\begin{array}{c}
p+1 \\
j
\end{array}\right) \cdot T_{j}=\frac{(n+1)^{p+1}}{p+1} \cdot\left(\begin{array}{c}
p+1 \\
p
\end{array}\right) \cdot\left(\begin{array}{l}
1 \\
0
\end{array}\right) \cdot B_{0}-(n+1)=\frac{(n+1)^{p+1}}{p+1} \cdot(p+1)-(n+1)= \\
& =(n+1)^{p+1}-(n+1),
\end{aligned}
$$

vagyis

$$
\sum_{j=1}^{p}\left(\begin{array}{c}
p+1 \\
j
\end{array}\right) \cdot T_{j}=(n+1)^{p+1}-(n+1) .
$$

Azonban, ha a (4.2.2) összefüggésben a $k$ helyére $p$-t írunk, akkor

$$
(n+1)^{p+1}=\left(\begin{array}{c}
p+1 \\
p+1
\end{array}\right) \cdot(n+1)+\left(\begin{array}{c}
p+1 \\
p
\end{array}\right) \cdot S_{1}+\left(\begin{array}{c}
p+1 \\
p-1
\end{array}\right) \cdot S_{2}+\ldots+\left(\begin{array}{c}
p+1 \\
2
\end{array}\right) \cdot S_{p-1}+\left(\begin{array}{c}
p+1 \\
1
\end{array}\right) \cdot S_{p},
$$

amely összefüggést átrendezve és felhasználva, hogy $\left(\begin{array}{c}p+1 \\ p+1-j\end{array}\right)=\left(\begin{array}{c}p+1 \\ j\end{array}\right)$ kapjuk, hogy

$$
(n+1)^{p+1}-(n+1)=\sum_{j=1}^{p}\left(\begin{array}{c}
p+1 \\
p+1-j
\end{array}\right) \cdot S_{j}=\sum_{j=1}^{p}\left(\begin{array}{c}
p+1 \\
j
\end{array}\right) \cdot S_{j} .
$$

Tehát:

$$
\sum_{j=1}^{p}\left(\begin{array}{c}
p+1 \\
j
\end{array}\right) \cdot S_{j}=(n+1)^{p+1}-(n+1) .
$$

A (4.2.22) és (4.2.23) alattiakat behelyettesítve a (4.2.17) alatti egyenlőségbe, kapjuk hogy:

$(n+1)^{p+1}-(n+1)=(n+1)^{p+1}-(n+1)+(p+1) \cdot \Delta$,

$\operatorname{azaz}(p+1) \cdot \Delta=0$.

Ez a kezdeti feltételek figyelembe vétele mellett, csak akkor lehetséges, ha $\Delta=0$.

Q.e.d. 
Lássuk néhány konkrét esetben az $S_{p}$ felírását a (4.2.16) összefüggés alapján!

Ha $p=3$, akkor

$$
\begin{aligned}
& S_{3}=\frac{1}{4} \cdot \sum_{k=0}^{3}\left[\left(\begin{array}{l}
4 \\
k
\end{array}\right) \cdot B_{k} \cdot(n+1)^{4-k}\right]= \\
& =\frac{1}{4} \cdot\left[\left(\begin{array}{l}
4 \\
0
\end{array}\right) \cdot 1 \cdot(n+1)^{4}+\left(\begin{array}{l}
4 \\
1
\end{array}\right) \cdot\left(-\frac{1}{2}\right) \cdot(n+1)^{3}+\left(\begin{array}{l}
4 \\
2
\end{array}\right) \cdot \frac{1}{6} \cdot(n+1)^{2}+0\right]= \\
& =\frac{(n+1)^{2}}{4} \cdot\left[(n+1)^{2}-2(n+1)+1\right]=\frac{(n+1)^{2}}{4} \cdot\left(n^{2}+2 n+1-2 n-2+1\right)=\frac{n^{2}(n+1)^{2}}{4} .
\end{aligned}
$$

Tehát:

$$
S_{3}=1^{3}+2^{3}+3^{3}+\ldots+n^{3}=\frac{n^{2}(n+1)^{2}}{4} .
$$

Ha $p=4$, akkor

$$
\begin{aligned}
& S_{4}=\frac{1}{5} \cdot \sum_{k=0}^{4}\left[\left(\begin{array}{l}
5 \\
k
\end{array}\right) \cdot B_{k} \cdot(n+1)^{5-k}\right]= \\
& =\frac{1}{5} \cdot\left[\left(\begin{array}{l}
5 \\
0
\end{array}\right) \cdot 1 \cdot(n+1)^{5}+\left(\begin{array}{l}
5 \\
1
\end{array}\right) \cdot\left(-\frac{1}{2}\right) \cdot(n+1)^{4}+\left(\begin{array}{l}
5 \\
2
\end{array}\right) \cdot \frac{1}{6} \cdot(n+1)^{3}+0+\left(\begin{array}{l}
5 \\
4
\end{array}\right) \cdot\left(-\frac{1}{30}\right) \cdot(n+1)\right]= \\
& =\frac{n+1}{5} \cdot\left[(n+1)^{4}-\frac{5}{2} \cdot(n+1)^{3}+\frac{5}{3} \cdot(n+1)^{2}-\frac{1}{6}\right]= \\
& =\frac{n+1}{30} \cdot\left(6 n^{4}+24 n^{3}+36 n^{2}+24 n+6-15 n^{3}-45 n^{2}-45 n-15+10 n^{2}+20 n+10-1\right)= \\
& =\frac{n+1}{30} \cdot\left(6 n^{4}+9 n^{3}+n^{2}-n\right)=\frac{n(n+1)}{30} \cdot\left(6 n^{3}+9 n^{2}+n-1\right)=\frac{n(n+1)(2 n+1)\left(3 n^{2}+3 n-1\right)}{30} .
\end{aligned}
$$

Tehát:

$$
S_{4}=1^{4}+2^{4}+3^{4}+\ldots+n^{4}=\frac{n(n+1)(2 n+1)\left(3 n^{2}+3 n-1\right)}{30} .
$$

Ha $p=5$, akkor

$$
\begin{aligned}
& S_{5}=\frac{1}{6} \cdot \sum_{k=0}^{5}\left[\left(\begin{array}{l}
6 \\
k
\end{array}\right) \cdot B_{k} \cdot(n+1)^{6-k}\right]= \\
& =\frac{1}{6} \cdot\left[\left(\begin{array}{l}
6 \\
0
\end{array}\right) \cdot 1 \cdot(n+1)^{6}+\left(\begin{array}{l}
6 \\
1
\end{array}\right) \cdot\left(-\frac{1}{2}\right) \cdot(n+1)^{5}+\left(\begin{array}{l}
6 \\
2
\end{array}\right) \cdot \frac{1}{6} \cdot(n+1)^{4}+0+\left(\begin{array}{l}
6 \\
4
\end{array}\right) \cdot\left(-\frac{1}{30}\right) \cdot(n+1)^{2}+0\right]= \\
& =\frac{(n+1)^{2}}{6} \cdot\left[(n+1)^{4}-3(n+1)^{3}+\frac{5}{2} \cdot(n+1)^{2}-\frac{1}{2}\right]= \\
& =\frac{(n+1)^{2}}{12} \cdot\left(2 n^{4}+8 n^{3}+12 n^{2}+8 n+2-6 n^{3}-18 n^{2}-18 n-6+5 n^{2}+10 n+5-1\right)=
\end{aligned}
$$




$$
=\frac{(n+1)^{2}}{12} \cdot\left(2 n^{4}+2 n^{3}-n^{2}\right)=\frac{n^{2}(n+1)^{2}\left(2 n^{2}+2 n-1\right)}{12} .
$$

Tehát:

$$
S_{5}=1^{5}+2^{5}+3^{5}+\ldots+n^{5}=\frac{n^{2}(n+1)^{2}\left(2 n^{2}+2 n-1\right)}{12}
$$

Ebben a fejezetben az azonos kitevőjü hatványösszegek kiszámításának problematikáját lineáris algebrai eszközökkel közelítettük meg. Ennek érdekében elöször felírtunk egy „alkalmas” összefüggést, majd ehhez hozzárendeltünk egy lineáris egyenletrendszert. Az egyenletrendszert Cramer-szabállyal megoldva, egy zárt formulát kaptunk az $S_{p}$ hatványösszegre, melynek felírása egy determináns kiszámítására vezethető vissza. A módszer általánosítható volt számtani sorozatokra is.

A lineáris egyenletrendszerrel való problémamegoldás kapcsolatot teremt a Bernoulliszámokkal is. Megmutattuk, hogy az általunk ismertetett eljárás alkalmas a Bernoulli-számok kiszámítására. Kapcsolatot írtunk fel a 3.4.3. fejezetben bemutatott Stirling-számok és a Bernoulli-számok között, majd a fejezet végén az első $n$ pozitív egész szám $p$-edik hatványainak összege és a Bernoulli-számok között.

Ez ismét szép példáját adta a matematika különböző területei közötti ,átfedések”, „határterületi összekapcsolhatóságok” igazolásának, feltárásának.

A nem rekurziós módszerekkel kapcsolatban általánosságban elmondható, hogy ezek:

1. az azonos kitevőjü hatványok összegének kiszámításánál nagyon hasznosnak bizonyulnak, mert a rekurziós összefüggésekkel ellentétben nincs szükség „megelőző” összegek ismeretére, alkalmazásuk azonnali eredményre vezet.

2. könnyen algoritmizálhatók s ennek okán - számítógép segítségével - akár nagyon magas hatványkitevőkre is formulák nyerhetők. 


\section{5. Összegzés, a kutatómunka eredményei}

Munkánkat a disszertáció lényegi részének összefoglalásával és a saját kutatási eredmények azonosításával zárjuk.

\subsection{Bevezetés}

Az értekezés bevezető részében azonosítottuk a vizsgált témát (hatványösszegek kiszámítása különböző módszerekkel), meghatároztuk az elvégzendő feladatokat és célkitüzéseket, felsoroltuk az alkalmazásra kerülő módszereket, továbbá leírtuk a dolgozat szerkezetét és logikai rendjét.

\subsection{Tudománytörténeti vizsgálat}

A 2. fejezetben megvizsgáltuk a probléma történeti aspektusait, azt a folyamatot, amelyben a különböző korok tudósai lépésről lépésre közelebb jutottak a megoldáshoz.

A hatványösszegek kiszámítása tárgykörében elsőként az ókori görög tudósok (Püthagorasz, Arkhimédész, Hüpsziklész, Nikomakhosz) értek el jelentős eredményeket, felhasználva több esetben is a figurális számokat. Az ó- és újkori kínai matematikában már megjelent a számtani sorozatok összegzése, illetve a sorozat általános tagjának kiszámítása. A többségében algebrai módszereket alkalmazó hindu matematikusok szintén képesek voltak a számtani sorozat tetszőleges tagjának kiszámítására, az első $n$ négyzetszám, illetve köbszám összegzésére, s ez utóbbi elmondható az arab-perzsa matematikusokról is. A probléma megoldása kapcsán a középkori és kora újkori európai gondolkodók köréből Levi ben Gerson, Thomas Harriot, Johann Faulhaber, Pierre de Fermat, valamint Blaise Pascal említhető, akik mind közelebb jutottak a végső megoldáshoz. A hatványösszeg kiszámítása minden kitevő esetén Jacob Bernoulli nevéhez füződik, aki ezzel a probléma végleges megoldását adta. Végül is a feldolgozott matematikatörténeti forrásmunkák tanúbizonysága szerint a hatványösszegek kiszámításának problematikája történetileg szép példája az emberi tudás fokozatos gyarapodásának, a gondolkodás fejlődésének és a matematikai módszertani apparátusok gazdagodásának

\subsection{Rekurziós módszerek}

A 3. fejezetben az $S_{p}=1^{p}+2^{p}+3^{p}+\ldots+n^{p} \quad(n, p \in N, n \geq 1)$ összeg meghatározásának rekurziós képletre vezető megoldását analizáltuk. Öt olyan megoldási módozatot vettünk részletes vizsgálat alá, ahol eltérő utakon jutottunk a kívánt rekurziós formulához. Ezeknek a módszereknek a közös tulajdonsága, hogy egy konkrét p-re felírt összeg kiszámításához szükség van a megelőző indexű összeg/összegek ismeretére. 


\subsubsection{Eredmények}

1. A mátrixos (táblázatos elrendezésü) módszerhez mátrixaritmetikai fogalmakat is felhasználtunk. E metodikánál megadtunk egy speciális $n x n$-es mátrixot, éspedig:

$$
M=\left[\begin{array}{ccccc}
1^{p-1} & 2^{p-1} & 3^{p-1} & \ldots & n^{p-1} \\
1^{p-1} & 2^{p-1} & 3^{p-1} & \ldots & n^{p-1} \\
1^{p-1} & 2^{p-1} & 3^{p-1} & \ldots & n^{p-1} \\
--- & --- & --- & --- & --- \\
1^{p-1} & 2^{p-1} & 3^{p-1} & \ldots & n^{p-1}
\end{array}\right] .
$$

Az elemeket először soronként összegeztük. Ezután speciális mátrixok segítségével (felső háromszög mátrix, alsó háromszög mátrix, diagonális mátrix) egy újabb összegzést elvégezve és az egyenlőséget felírva, a részletszámítások után megkaptuk az

$$
S_{p}=(n+1) \cdot S_{p-1}-\sum_{k=1}^{n} S_{k ; p-1}
$$

rekurziós formulát.

Felírtuk a képletnek az első öt pozitív egész hatványra vonatkozó eseteit. Ezek egy része a középiskolából már jól ismert formula.

$$
\begin{aligned}
& S_{1}=1+2+3+\ldots+n=\frac{n(n+1)}{2} . \\
& S_{2}=1^{2}+2^{2}+3^{2}+\ldots+n^{2}=\frac{n(n+1)(2 n+1)}{6} . \\
& S_{3}=1^{3}+2^{3}+3^{3}+\ldots+n^{3}=\frac{n^{2}(n+1)^{2}}{4} . \\
& S_{4}=1^{4}+2^{4}+3^{4}+\ldots+n^{4}=\frac{n(n+1)(2 n+1)\left(3 n^{2}+3 n-1\right)}{30} . \\
& S_{5}=1^{5}+2^{5}+3^{5}+\ldots+n^{5}=\frac{n^{2}(n+1)^{2}\left(2 n^{2}+2 n-1\right)}{12} .
\end{aligned}
$$

Megmutattuk, hogy a megoldás gondolatmenete alkalmazható az alternáló összeg azaz az $S_{p}^{*}=1^{p}-2^{p}+3^{p}-4^{p}+\ldots+(-1)^{n-1} \cdot n^{p}-$ esetére is. Ebben az esetben a következő speciális mátrixot használtuk:

$$
\bar{M}=\left[\begin{array}{ccccc}
1^{p-1} & -2^{p-1} & 3^{p-1} & \ldots & (-1)^{n-1} \cdot n^{p-1} \\
1^{p-1} & -2^{p-1} & 3^{p-1} & \ldots & (-1)^{n-1} \cdot n^{p-1} \\
1^{p-1} & -2^{p-1} & 3^{p-1} & \ldots & (-1)^{n-1} \cdot n^{p-1} \\
--- & --- & --- & --- & --- \\
1^{p-1} & -2^{p-1} & 3^{p-1} & \ldots & (-1)^{n-1} \cdot n^{p-1}
\end{array}\right] .
$$

Az így nyert rekurziós képlet végső alakja:

$$
S_{p}^{*}=(n+1) \cdot S_{p-1}^{*}-\sum_{k=1}^{n} S_{k ; p-1}^{*} \cdot
$$


Ezt követően bemutattuk a formula alkalmazhatóságát néhány speciális eset közreadásával (az első négy pozitív egész $p$-re).

$$
\begin{aligned}
& S_{1}^{*}=1-2+3-4+\ldots+(-1)^{n-1} \cdot n=\frac{1+(-1)^{n-1} \cdot(2 n+1)}{4} . \\
& S_{2}^{*}=1^{2}-2^{2}+3^{2}-4^{2}+\ldots+(-1)^{n-1} \cdot n^{2}=(-1)^{n-1} \cdot \frac{n(n+1)}{2} . \\
& S_{3}^{*}=1^{3}-2^{3}+3^{3}-4^{3}+\ldots+(-1)^{n-1} \cdot n^{3}=\frac{-1+(-1)^{n-1} \cdot(2 n+1)\left(2 n^{2}+2 n-1\right)}{8} . \\
& S_{4}^{*}=1^{4}-2^{4}+3^{4}-4^{4}+\ldots+(-1)^{n-1} \cdot n^{4}=(-1)^{n-1} \cdot \frac{n\left(n^{3}+2 n^{2}-1\right)}{2} .
\end{aligned}
$$

Elvégeztük a kiinduló mátrix (táblázat) elemeinek „lépcsős” összegzését is, s így mátrixaritmetikai fogalmak használata nélkül juthattunk el az előbbiekben megismert összefüggésekhez. Ezen túlmenően egy ,alkalmas” ábra felhasználásával szemléltettük a kívánt rekurzióhoz történő eljutást.

2. Az összegzési feladat második fajta megoldásánál a rekurziós formulához egy speciális azonosságból, mégpedig a

$$
\begin{aligned}
& (k+1) \cdot k^{p}-k \cdot(k-1)^{p}= \\
& =(p+1) \cdot k^{p}-\left(\begin{array}{l}
p \\
2
\end{array}\right) \cdot k^{p-1}+\left(\begin{array}{l}
p \\
3
\end{array}\right) \cdot k^{p-2}-\left(\begin{array}{l}
p \\
4
\end{array}\right) \cdot k^{p-3}+\ldots+(-1)^{p+1} \cdot\left(\begin{array}{l}
p \\
p
\end{array}\right) \cdot k
\end{aligned}
$$

azonosságból kiindulva jutottunk el $\left(k \in R, p \in Z^{+}\right)$. A számítások végén kaptuk, hogy:

$$
(p+1) \cdot S_{p}=(n+1) n^{p}+\left(\begin{array}{l}
p \\
2
\end{array}\right) \cdot S_{p-1}-\left(\begin{array}{l}
p \\
3
\end{array}\right) \cdot S_{p-2}+\ldots+(-1)^{p} \cdot\left(\begin{array}{l}
p \\
p
\end{array}\right) \cdot S_{1} \cdot
$$

Alkalmaztuk a képletet $p$ néhány konkrét esetére.

A rekurzióhoz vezető gondolatmenethez hasonló úton két másik összefüggésből kiindulva összegképletek közötti összefüggéseket tudtunk meghatározni a páratlan, illetve a páros indexek esetére. Általános formulákat adtunk meg és ezeket néhány speciális esetre konkretizáltuk.

Az általános formulák:

- páratlan index esetén:

$$
2^{p-1} \cdot S_{1}^{p}=\left(\begin{array}{c}
p \\
1
\end{array}\right) \cdot S_{2 p-1}+\left(\begin{array}{c}
p \\
3
\end{array}\right) \cdot S_{2 p-3}+\left(\begin{array}{c}
p \\
5
\end{array}\right) \cdot S_{2 p-5}+\ldots,
$$

- páros index esetén:

$$
\begin{aligned}
& 3 \cdot 2^{p-1} \cdot S_{2} \cdot S_{1}^{p-1}= \\
& =\left[\left(\begin{array}{l}
p \\
0
\end{array}\right)+2 \cdot\left(\begin{array}{l}
p \\
1
\end{array}\right)\right] \cdot S_{2 p}+\left[\left(\begin{array}{l}
p \\
2
\end{array}\right)+2 \cdot\left(\begin{array}{l}
p \\
3
\end{array}\right)\right] \cdot S_{2 p-2}+\left[\left(\begin{array}{l}
p \\
4
\end{array}\right)+2 \cdot\left(\begin{array}{l}
p \\
5
\end{array}\right)\right] \cdot S_{2 p-4}+\ldots .
\end{aligned}
$$

A képletek segítségével nyert néhány speciális eset: 


$$
\begin{array}{lll}
4 \cdot S_{1}^{3}=3 \cdot S_{5}+S_{3}, & \text { illetve } & S_{5}=\frac{S_{1}^{2}}{3} \cdot\left(4 \cdot S_{1}-1\right) \\
2 \cdot S_{1}^{4}=S_{7}+S_{5}, & \text { illetve } & S_{7}=\frac{S_{1}^{2}}{3} \cdot\left(6 \cdot S_{1}^{2}-4 \cdot S_{1}+1\right) . \\
6 \cdot S_{2} \cdot S_{1}=5 \cdot S_{4}+S_{2}, & \text { illetve } & S_{4}=\frac{S_{2}}{5} \cdot\left(6 \cdot S_{1}-1\right) . \\
12 \cdot S_{2} \cdot S_{1}^{2}=7 \cdot S_{6}+5 \cdot S_{4}, & \text { illetve } & S_{6}=\frac{S_{2}}{7} \cdot\left(12 \cdot S_{1}^{2}-6 \cdot S_{1}+1\right) .
\end{array}
$$

3. A rekurziós formula előállítható a binomiális tétel segítségével is. Itt a kezdő lépés az alábbi összefüggés felírása ( $a \in R, p \in N$ ):

$$
(a+1)^{p+1}-a^{p+1}=\left(\begin{array}{c}
p+1 \\
1
\end{array}\right) \cdot a^{p}+\left(\begin{array}{c}
p+1 \\
2
\end{array}\right) \cdot a^{p-1}+\ldots+\left(\begin{array}{c}
p+1 \\
p
\end{array}\right) \cdot a+\left(\begin{array}{c}
p+1 \\
p+1
\end{array}\right) .
$$

Az $a$ helyébe rendre behelyettesítve az 1,2,..,n természetes számokat, a kapott összefüggéseket összegezve, az összevonások és átrendezések után viszonylag rövid részletszámításokkal a következő eredményt kaptuk:

$$
(p+1) \cdot S_{p}=(n+1)^{p+1}-\left(\begin{array}{c}
p+1 \\
2
\end{array}\right) \cdot S_{p-1}-\ldots-\left(\begin{array}{c}
p+1 \\
p
\end{array}\right) \cdot S_{1}-\left(\begin{array}{c}
p+1 \\
p+1
\end{array}\right) \cdot(n+1) .
$$

Ezután felírtuk a kapott összefüggés három speciális esetét.

Hasonló eljárással általánosítást végeztünk a számtani sorozatok esetére is, így rekurziós formulát írtunk fel az

$$
S_{p}(a, d)=a_{1}^{p}+a_{2}^{p}+a_{3}^{p}+\ldots+a_{n}^{p}=\sum_{i=1}^{n} a_{i}^{p}=\sum_{i=1}^{n}[a+(i-1) \cdot d]^{p}
$$

összeg meghatározására, ahol $a$ az $\left\{a_{n}\right\}_{n \geq 1}$ számtani sorozat első eleme, míg $d$ a sorozat differenciája $(a, d \in R)$. Ez esetben az

$$
a_{i+1}^{p+1}-a_{i}^{p+1}=\left(\begin{array}{c}
p+1 \\
1
\end{array}\right) \cdot a_{i}^{p} \cdot d+\ldots+\left(\begin{array}{c}
p+1 \\
p
\end{array}\right) \cdot a_{i}^{1} \cdot d^{p}+\left(\begin{array}{c}
p+1 \\
p+1
\end{array}\right) \cdot d^{p+1}
$$

összefüggésből indultunk ki és a számítások végén a kapott formula az alábbi:

$$
(p+1) \cdot d \cdot S_{p}(a, d)=(a+n d)^{p+1}-a^{p+1}-\sum_{k=2}^{p+1}\left[d^{k} \cdot\left(\begin{array}{c}
p+1 \\
k
\end{array}\right) \cdot S_{p+1-k}(a, d)\right] .
$$

Ezután felírtuk ennek a formulának néhány konkrét $d$-re és $p$-re vonatkozó általános, majd néhány konkrét $a$-ra vonatkozó speciális esetét (összesen 27 esetet). Közülük itt bemutatunk néhány érdekeset. Például:

$$
\begin{aligned}
& S_{1}(a, 3)=\frac{n}{2} \cdot(3 n+2 a-3) . \\
& S_{2}(a, 1)=\frac{n}{6} \cdot\left[2 n^{2}+3 n(2 a-1)+6 a^{2}-6 a+1\right] . \\
& S_{3}(a, 2)=n\left[2 n^{3}+4 n^{2}(a-1)+n\left(3 a^{2}-6 a+2\right)+a^{3}-3 a^{2}+2 a\right] .
\end{aligned}
$$




$$
\begin{aligned}
& S_{1}(n+1,2)=(n+1)+(n+3)+\ldots+(3 n-1)=2 n^{2} . \\
& S_{2}(1,3)=1^{2}+4^{2}+\ldots+(3 n-2)^{2}=\frac{n}{2} \cdot\left(6 n^{2}-3 n-1\right) . \\
& S_{3}(1,2)=1^{3}+3^{3}+\ldots+(2 n-1)^{3}=n^{2}\left(2 n^{2}-1\right) . \\
& S_{3}(2,3)=2^{3}+5^{3}+\ldots+(3 n-1)^{3}=\frac{n(3 n+1)\left(9 n^{2}+3 n-4\right)}{4} .
\end{aligned}
$$

Kidolgoztuk a probléma megoldását az első $n$ pozitív egész szám $p$-edik hatványa váltakozó elöjelü összegének esetére is. Ennek végső formulája:

$$
\begin{aligned}
& 2 \cdot(p+1) \cdot S_{p}^{*}= \\
& =(-1)^{n-1} \cdot\left[(n+2)^{p+1}-(n+1)^{p+1}-2^{p}\right]+2^{p}-1-\sum_{k=2}^{p}\left(\begin{array}{c}
p+1 \\
k
\end{array}\right) \cdot S_{p+1-k}^{*} \cdot 2^{k} .
\end{aligned}
$$

Ezután felírtuk az alternáló összeg két speciális esetét ( $p=3 ; 4$ kitevőkre).

A továbbiakban elvégeztük az általánosítást a számtani sorozat alternáló összegére is. Ez esetben az előállítás eredménye az alábbi:

$$
\begin{aligned}
& 2 d \cdot(p+1) \cdot S_{p}^{*}(a, d)=(-1)^{n-1} \cdot\left[a_{n+2}^{p+1}-a_{n+1}^{p+1}-d \cdot(2 d)^{p}\right]+ \\
& +a_{2}^{p+1}-a_{1}^{p+1}-d \cdot(2 d)^{p}-\sum_{k=2}^{p}\left(\begin{array}{c}
p+1 \\
k
\end{array}\right) \cdot S_{p+1-k}^{*}(a, d) \cdot(2 d)^{k} .
\end{aligned}
$$

Az értekezésben szereplő 3 általános és 12 konkrét esetből itt az alábbiakat mutatjuk be:

$$
\begin{aligned}
& S_{1}^{*}(a, d)=\frac{(-1)^{n-1} \cdot(2 n d+2 a-d)+2 a-d}{4} . \\
& S_{2}^{*}(a, d)=\frac{(-1)^{n-1} \cdot\left[n^{2} d^{2}+n d(2 a-d)+a^{2}-a d\right]+a^{2}-a d}{2} . \\
& S_{1}^{*}(1,2)=1-3+5-7+\ldots+(-1)^{n-1} \cdot(2 n-1)=(-1)^{n-1} \cdot n . \\
& S_{2}^{*}(2,3)=2^{2}-5^{2}+8^{2}-11^{2}+\ldots+(-1)^{n-1} \cdot(3 n-1)^{2}=\frac{(-1)^{n-1} \cdot\left(9 n^{2}+3 n-2\right)-2}{2} . \\
& S_{3}^{*}(1,2)=1^{3}-3^{3}+5^{3}-7^{3}+\ldots+(-1)^{n-1} \cdot(2 n-1)^{3}=(-1)^{n-1} \cdot n\left(4 n^{2}-3\right) .
\end{aligned}
$$

4. Hatványösszegek kiszámítására vezető rekurziós formulát a szimmetria segítségével is elő lehet állítani. Ehhez először definiáltuk az emelkedő és süllyedő faktoriális fogalmát, majd ismertettünk egy tulajdonságot ezekkel kapcsolatban.

Az emelkedő faktoriálishoz egy sorozatot rendeltünk, melynek tagjai között előbb egy rekurziós kapcsolatot teremtettünk, majd ezeket a tagokat összegeztuik. A kapott teleszkópikus összeg eredménye és az $1,2, \ldots,(p-1)$ számokhoz rendelt $s_{1}, s_{2}, \ldots, s_{p-1}$ szimmetrikus összegek segítségével eljutottunk a kívánt rekurziós formulához, amely a következő:

$$
S_{p}=\frac{n(n+1)(n+2) \ldots(n+p)}{p+1}-\sum_{i=1}^{p-1} s_{i} \cdot S_{p-i} .
$$


Akárcsak az előző módszereknél, itt is ismételten felírtuk a kapott formula $p=3 ; 4 ; 5$ speciális eseteit.

Bevezettük a Bell- és Stirling-számokat, rekurziós összefüggéseket írtunk fel közöttük, majd kapcsolatot teremtettünk többek között az emelkedö/süllyedő faktoriális, a Stirling-számok, valamint az $x$ határozatlan pozitív egész kitevőjü hatványai között. Megadtuk az első $n$ pozitív egész szám reciprokainak összegét az elsőfajú Stirling-számok segítségével, majd ismertettük a Catalan-összefüggést $-\mathrm{s}$ ezzel sikerült „hidakat” létesítenünk a matematika más területei felé is.

5. Az azonos kitevőjü hatványok összegzésének feladata megközelíthető az analízis módszereinek felhasználásával is. A kívánt rekurzió megkapható egy arra „alkalmas” függvény deriválása segítségével. Itt a kiinduló összefüggés az

$$
\left(e^{x}-1\right) \cdot F_{n}(x)=e^{(n+1) \cdot x}-e^{x}, \text { ahol } F_{n}(x)=\sum_{l=1}^{n} e^{l \cdot x}, n \in Z^{+} .
$$

Kiszámolva az összefüggés mindkét oldalának $(p+1)$-edrendü deriváltját, majd $x$ helyébe 0-át írva és a szükséges számításokat elvégezve megoldásként az alábbi - a binomiális módszer esetén már megismert - rekurziós képlet adódott:

$$
(p+1) \cdot S_{p}=(n+1)^{p+1}-\left(\begin{array}{c}
p+1 \\
2
\end{array}\right) \cdot S_{p-1}-\ldots-\left(\begin{array}{c}
p+1 \\
p
\end{array}\right) \cdot S_{1}-\left(\begin{array}{c}
p+1 \\
p+1
\end{array}\right) \cdot(n+1) .
$$

Egy másik speciális függvény $-F_{n}(x)=\sum_{l=1}^{n} e^{a_{l} \cdot x}$ - felhasználásával elvégeztük az általánosítást a számtani sorozatok esetére. Eredményül kaptuk, hogy

$$
\begin{aligned}
& (p+1) \cdot d \cdot S_{p}(a, d)=(a+n d)^{p+1}-a^{p+1}-\left(\begin{array}{c}
p+1 \\
2
\end{array}\right) \cdot d^{2} \cdot S_{p-1}(a, d)- \\
& -\left(\begin{array}{c}
p+1 \\
3
\end{array}\right) \cdot d^{3} \cdot S_{p-2}(a, d)-\ldots-\left(\begin{array}{c}
p+1 \\
p
\end{array}\right) \cdot d^{p} \cdot S_{1}(a, d)-\left(\begin{array}{c}
p+1 \\
p+1
\end{array}\right) \cdot d^{p+1} \cdot S_{0}(a, d) .
\end{aligned}
$$

A metodikát az $F_{n}(x)=\sum_{l=1}^{n}(-1)^{l-1} \cdot e^{l \cdot x}$ függvény segítségével alkalmaztuk az első $n$ pozitív egész szám $p$-edik hatványa alternáló összegére is. Itt a végső formulára a

$$
\begin{aligned}
& 2 \cdot(p+1) \cdot S_{p}^{*}= \\
& =(-1)^{n-1} \cdot\left[(n+2)^{p+1}-(n+1)^{p+1}-2^{p}\right]+2^{p}-1-\sum_{k=2}^{p}\left(\begin{array}{c}
p+1 \\
k
\end{array}\right) \cdot S_{p+1-k}^{*} \cdot 2^{k}
\end{aligned}
$$

adódott.

Megvizsgáltuk, hogy a módszer hogyan „müködik” a számtani sorozat alternáló összegére. A speciális függvény $\left(F_{n}(x)=\sum_{l=1}^{n}(-1)^{l-1} \cdot e^{a_{l} \cdot x}\right)$ felírása, a deriválások és az elvégzendő részletszámítások után a rekurziós képlet a következő alakot öltötte:

$$
\begin{aligned}
& 2 d \cdot(p+1) \cdot S_{p}^{*}(a, d)=(-1)^{n-1} \cdot\left[a_{n+2}^{p+1}-a_{n+1}^{p+1}-d \cdot(2 d)^{p}\right]+ \\
& +a_{2}^{p+1}-a_{1}^{p+1}-d \cdot(2 d)^{p}-\sum_{k=2}^{p}\left(\begin{array}{c}
p+1 \\
k
\end{array}\right) \cdot S_{p+1-k}^{*}(a, d) \cdot(2 d)^{k} .
\end{aligned}
$$




\subsection{Nem rekurzióra vezető megoldási módszerek}

A 4. fejezet a hatványösszegzés nem rekurziós formulára vezető módszereivel foglalkozik. Itt két olyan - nagyon hasznos - megoldási eljárást mutatunk be, amelyek olyan képletekre vezetnek, amelyek az első $n$ db pozitív egész szám $p$-edik hatványának összegét azonnal megadják, s ez esetben nincs szükség úgymond a „megelőző” ( $p$-nél kisebb indexű) összegek kiszámítására.

\subsubsection{Eredmények}

6. A kitüzött feladatot egy, a differenciasorozatok felhasználásán alapuló módszer segítségével oldottuk meg. Ehhez elöször értelmeztük a differenciasorozat fogalmát, majd definiáltuk mit értünk $p$-edrendű számtani sorozaton. Bebizonyítottuk, hogy bármely $p$-edrendü számtani sorozat $k$-adik tagja $k$-nak egy $p$-edfokú polinomjával adható meg. Ez utóbbit szemléltettuik két konkrét példán is.

$\sigma_{n ; p}$-vel jelölve a $p$-edrendủ számtani sorozat első $n$ tagjának összegét, megadtuk $\sigma_{n ; p}-\mathrm{t}$ az egymás után következő differenciasorozatok kezdő tagjainak segítségével a következőképpen:

$$
\sigma_{n ; p}=\left(\begin{array}{l}
n \\
1
\end{array}\right) \cdot a_{1}+\left(\begin{array}{l}
n \\
2
\end{array}\right) \cdot \Delta a_{1}+\left(\begin{array}{l}
n \\
3
\end{array}\right) \cdot \Delta^{2} a_{1}+\ldots+\left(\begin{array}{c}
n \\
p+1
\end{array}\right) \cdot \Delta^{p} a_{1},
$$

ahol $a_{1} ; \Delta a_{1} ; \Delta^{2} a_{1} ; \ldots ; \Delta^{p} a_{1}$ a megfelelő differenciasorozatok első tagjai.

Mint a fejezet bevezetésében elmondtuk, a módszer előnye, hogy $\sigma_{n ; p}$ kiszámításához nem kell meghatározni a $p$-t megelőző indexű összegeket.

Ez esetben is felírtuk a korábbról már jól ismert képleteket a $p=3 ; 4 ; 5$ kitevőkre. Továbbá megadtuk a formula segítségével a számtani sorozat esetére először a $p=1 ; 2 ; 3$ kitevőkre érvényes általános eseteket, majd speciális eseteket írtunk fel az alábbiak szerint: az $a=1$ esetben a $d=1 ; 2$ eseteket, majd az $a=2, d=3$, illetve az $a=5, d=6$ számok esetén érvényes összefüggéseket. Itt az alábbi két általános és két speciális esetet mutatjuk be:

$$
\begin{aligned}
& S_{2}(a, d)=\frac{n}{6} \cdot\left[2 n^{2} d^{2}+3 n d(2 a-d)+6 a^{2}-6 a d+d^{2}\right] . \\
& S_{3}(a, d)=\frac{n}{4} \cdot\left[n^{3} d^{3}+2 n^{2} d^{2}(2 a-d)+n d\left(6 a^{2}-6 a d+d^{2}\right)+4 a^{3}-6 a^{2} d+2 a d^{2}\right] . \\
& S_{2}(5,6)=5^{2}+11^{2}+17^{2}+\ldots+(6 n-1)^{2}=n\left(12 n^{2}+12 n+1\right) . \\
& S_{3}(2,3)=2^{3}+5^{3}+8^{3}+\ldots+(3 n-1)^{3}=\frac{n(3 n+1)\left(9 n^{2}+3 n-4\right)}{4} .
\end{aligned}
$$

7. A probléma megoldása megadható lineáris algebrai ismeretek/eszközök felhasználásával is. E módszernél kiindulásként felírtuk az

$$
(a+1)^{k+1}-a^{k+1}=\left(\begin{array}{c}
k+1 \\
1
\end{array}\right) \cdot a^{k}+\left(\begin{array}{c}
k+1 \\
2
\end{array}\right) \cdot a^{k-1}+\ldots+\left(\begin{array}{c}
k+1 \\
k
\end{array}\right) \cdot a+\left(\begin{array}{c}
k+1 \\
k+1
\end{array}\right)
$$


azonosságot, ahol $a \in R$ és $k \in N$.

Az összefüggésben az $a$ helyére rendre behelyettesítettük az 1,2,..,n számokat. Az egyenlőségeket oldalanként összegeztük, majd átrendezéssel kaptuk, hogy

$$
(n+1)^{k+1}=\left(\begin{array}{c}
k+1 \\
k+1
\end{array}\right) \cdot(n+1)+\left(\begin{array}{c}
k+1 \\
k
\end{array}\right) \cdot S_{1}+\ldots+\left(\begin{array}{c}
k+1 \\
2
\end{array}\right) \cdot S_{k-1}+\left(\begin{array}{c}
k+1 \\
1
\end{array}\right) \cdot S_{k} .
$$

Ehhez az összefüggéshez hozzárendeltünk egy speciális lineáris egyenletrendszert, melyet úgy kaptunk, hogy a $k$ helyére rendre behelyettesítettük a $0,1,2, \ldots, p$ értékeket. Az így kapott $(p+1)$ egyenletből álló egyenletrendszerben ismeretleneknek tekintettük az $S_{1}, S_{2}, \ldots, S_{p}$,,szimbólumokat”. Bebizonyítottuk, hogy a lineáris egyenletrendszer megoldható a Cramer-szabállyal.

Így az $S_{p}$-re a következő formula adódott:

$$
S_{p}=\frac{1}{(p+1) !} \cdot\left|\begin{array}{cccccc}
\left(\begin{array}{l}
1 \\
1
\end{array}\right) & 0 & 0 & \ldots & 0 & n+1 \\
\left(\begin{array}{l}
2 \\
2
\end{array}\right) & \left(\begin{array}{l}
2 \\
1
\end{array}\right) & 0 & \ldots & 0 & (n+1)^{2} \\
\left(\begin{array}{l}
3 \\
3
\end{array}\right) & \left(\begin{array}{l}
3 \\
2
\end{array}\right) & \left(\begin{array}{l}
3 \\
1
\end{array}\right) & \ldots & 0 & (n+1)^{3} \\
-\left(\begin{array}{l}
p \\
p
\end{array}\right) & \left(\begin{array}{c}
p \\
p-1
\end{array}\right) & \left(\begin{array}{c}
p \\
p-2
\end{array}\right) & \cdots & \left(\begin{array}{c}
p \\
1
\end{array}\right) & (n+1)^{p} \\
\left(\begin{array}{c}
p+1 \\
p+1
\end{array}\right) & \left(\begin{array}{c}
p+1 \\
p
\end{array}\right) & \left(\begin{array}{c}
p+1 \\
p-1
\end{array}\right) & \ldots & \left(\begin{array}{c}
p+1 \\
2
\end{array}\right) & (n+1)^{p+1}
\end{array}\right| .
$$

Ismételten elvégeztük a konkrét összeg kiszámítását a $p=3 ; 4 ; 5$ esetekre, $\mathrm{s}$ itt is megkaptuk a korábban már többször felírt megfelelő eredményeket.

Általánosítottuk a módszert a számtani sorozatokra. Az elvégzett számítások után a kapott formula a következő:

$$
S_{p}(a, d)=\frac{1}{(p+1) ! d^{p+1}} \cdot D_{p}^{\prime},
$$

ahol

$$
D_{p}^{\prime}=\left|\begin{array}{ccccc}
\left(\begin{array}{l}
1 \\
1
\end{array}\right) \cdot d & 0 & \ldots & 0 & (a+n d)^{1}-a^{1} \\
\left(\begin{array}{l}
2 \\
2
\end{array}\right) \cdot d^{2} & \left(\begin{array}{l}
2 \\
1
\end{array}\right) \cdot d & \ldots & 0 & (a+n d)^{2}-a^{2} \\
\left(\begin{array}{l}
3 \\
3
\end{array}\right) \cdot d^{3} & \left(\begin{array}{l}
3 \\
2
\end{array}\right) \cdot d^{2} & \ldots & 0 & (a+n d)^{3}-a^{3} \\
---- & ----- & --- & ----- & ----- \\
\left(\begin{array}{l}
p \\
p
\end{array}\right) \cdot d^{p} & \left(\begin{array}{c}
p \\
p-1
\end{array}\right) \cdot d^{p-1} & \ldots & \left(\begin{array}{c}
p \\
1
\end{array}\right) \cdot d & (a+n d)^{p}-a^{p} \\
\left(\begin{array}{l}
p+1 \\
p+1
\end{array}\right) \cdot d^{p+1} & \left(\begin{array}{c}
p+1 \\
p
\end{array}\right) \cdot d^{p} & \ldots & \left(\begin{array}{c}
p+1 \\
2
\end{array}\right) \cdot d^{2} & (a+n d)^{p+1}-a^{p+1}
\end{array}\right| .
$$


Érdekes kapcsolódó eredmény, hogy a módszer jól használható a Bernoulli-számok kiszámítására is. Ennek illusztrálásaképpen munkánkban be is mutattuk a módszer alkalmazását a fenti számok kiszámítására.

Így a $(p+1)$-edik Bernoulli-szám az alábbi képlettel számítható ki:

$$
B_{p}=\frac{1}{(p+1) !} \cdot\left|\begin{array}{cccccc}
\left(\begin{array}{l}
1 \\
1
\end{array}\right) & 0 & 0 & \ldots & 0 & 1 \\
\left(\begin{array}{l}
2 \\
2
\end{array}\right) & \left(\begin{array}{l}
2 \\
1
\end{array}\right) & 0 & \ldots & 0 & 0 \\
\left(\begin{array}{l}
3 \\
3
\end{array}\right) & \left(\begin{array}{l}
3 \\
2
\end{array}\right) & \left(\begin{array}{l}
3 \\
1
\end{array}\right) & \ldots & 0 & 0 \\
--- & --- & --- & --- & --- & --- \\
\left(\begin{array}{l}
p \\
p
\end{array}\right) & \left(\begin{array}{c}
p \\
p-1
\end{array}\right) & \left(\begin{array}{c}
p \\
p-2
\end{array}\right) & \ldots & \left(\begin{array}{c}
p \\
1
\end{array}\right) & 0 \\
\left(\begin{array}{l}
p+1 \\
p+1
\end{array}\right) & \left(\begin{array}{c}
p+1 \\
p
\end{array}\right) & \left(\begin{array}{c}
p+1 \\
p-1
\end{array}\right) & \ldots & \left(\begin{array}{c}
p+1 \\
2
\end{array}\right) & 0
\end{array}\right|,
$$

ahol $p=0 ; 1 ; 2 ; 3 ; \ldots$.

Kipróbáltuk a fenti eredmény alkalmazhatóságát két konkrét Bernoulli-szám kiszámításával. Ezen túlmenően bebizonyítottuk, hogy $B_{1}$ kivételével valamennyi páratlan indexü Bernoulli-szám nulla, illetve hogy $B_{p}$ egy másik - szintén determinánssal történő - előállítása egyenértékü az általunk megadottal.

A fejezet végén összefüggéseket mutattunk be a Stirling- és a Bernoulli-számok között, illetve bebizonyítottuk az első $n$ pozitív egész szám $p$-edik hatványának összege és a Bernoulli-számok között fennálló kapcsolatot, amely a következő:

$$
S_{p}=\frac{1}{p+1} \cdot \sum_{k=0}^{p}\left(\begin{array}{c}
p+1 \\
k
\end{array}\right) \cdot B_{k} \cdot(n+1)^{p+1-k} .
$$

S végezetül ezen eredmények mellett megemlítjük, hogy a könnyebb érthetőség okán és az alkalmazott módszereket gazdagítandó több fejezetben, valamint a függelékben is szemléletes bizonyításokkal kívántuk változatosabbá tenni a mondanivalót.

\subsection{Saját kutatási eredmények}

A dolgozat egy bizonyos logikai fonálra felfüzve komplexen mutat be szakirodalmi és saját kutatási eredményeket. Ennek okán mindenképpen szükségesnek látjuk elhatárolni, hogy melyek a saját és melyek a szakirodalomból felhasznált eredmények.

\subsubsection{Saját kutatási eredmények a rekurziós módszerek körében}

A mátrixos metodika esetében a módszer egésze saját ötlet, akárcsak az ezzel kapcsolatos alkalmazások (speciális esetek). Szintén önálló munka a módszer adaptálása az alternáló összegre, illetve annak konkrét eseteire. A lépcsős összegzés alkalmazása két konkrét $p$ 
értékre ( $p=2 ; 3$ ) megtalálható a [38]-ban. A rekurzió általános alakjának lépcsős módszerrel való felírása saját kidolgozás (mind az összeg, mind pedig az alternáló összeg esetében).

A speciális azonosság felhasználását igénylő második módszernél maga a metodika Kiss Sándortól [19] való átvétel. Itt a számítások és a konkrét esetekre való alkalmazások jelölhetők meg saját munkaként. Két másik speciális azonosság segítségével rekurziókat írtunk fel a hatványösszegek páros/páratlan kitevői eseteire. Ennél az ötlet Pólya György [7] egyik feladatából adódott. A számítások és a speciális esetek ( $p=1 ; 2 ; 3 ; 4 ; 5)$ mindkét típusú kitevő esetén szintén saját eredmények.

A binomiális tételen alapuló módszer közismert. Ennél a fejezetrésznél a számtani sorozatra, az alternáló összegre, továbbá a számtani sorozat alternáló összegére való általánosítás, valamint a speciális esetek felírása számít önálló munkának.

A szimmetrikus összegek segítségével előállított rekurzió esetében mind a módszer, mind pedig az alkalmazások saját munkaként vehetők számításba. Az emelkedő/süllyedő faktoriálisról, a Stirling- és Bell-számokról írottak Hajnal Péter [3], Ioan Tomescu [13] és Tóth László [14] müveire alapozódnak azzal a megjegyzéssel, hogy egyes tételek bizonyítása saját munka eredménye.

Ami a differenciálszámítást felhasználó módszert illeti, itt a teljes fejezet önálló kutatás alapján íródott.

\subsubsection{Saját kutatási eredmények a nem rekurziós módszerek esetén}

A differenciasorozatokon alapuló módszer előállítását a Szele Tibor [12] könyvében leírtak alapján végeztük. E fejezetrészben saját munkának a különböző speciális esetek felírása valamint a módszer számtani sorozatokra történő alkalmazása tekinthető.

A lineáris algebrai eszközökkel operáló metodika Dumitru Acu [15] jegyzete alapján készült. E téma kapcsán saját munkának számítható:

- a módszer általánosítása számtani sorozatokra,

- a Bernoulli-számoknak a - fenti módszer alapgondolatához hasonló módon való kiszámítása, továbbá

- annak igazolása, hogy a Bernoulli-számok determinánsok segítségével történő kiszámításának kétféle felírása egyenértékü.

A Bernoulli- és Stirling-számok, valamint az $S_{p}$ közötti kapcsolatok különböző szakirodalmi forrásokból származnak.

\subsection{Záró gondolatok}

Kutatásaink során sem a külföldi, sem a hazai szakirodalomban nem találtunk olyan átfogó, rendszerező munkát, ami az $S_{p}$ különböző metodikákkal való kiszámítására irányul. Többek között ez is arra bátorított bennünket, hogy e témával behatóbban foglalkozzunk. E tekintetben reményeink szerint jelen dolgozat egyfajta hiánypótló, átfogó jellegű munkának számít - nyilván a teljesség igénye nélkül. Szándékaink szerint azt kívántuk bemutatni, hogy hogyan juthatunk el - a gondolkodás sokféle útján és természetesen változatos matematikai módszertani apparátusok felhasználásával - egy adott probléma megoldásához. 
Miért is lehet fontos egy ilyenfajta „módszertani gyüjtemény”?

Talán leginkább annak okán, hogy a matematika oktatásában a különböző megoldási ötletek tudatosítását, összehasonlítását igen jól szolgálhatja egy-egy feladat, probléma többféle módszerrel történő megoldásának vizsgálata. Mind a középiskola magasabb évfolyamain, mind pedig az egyetemi oktatásban számos lehetőség kínálkozik a matematikai gondolkodás és az ahhoz szorosan kapcsolódó megoldási folyamat többféle módját bemutatni, hiszen itt már sokrétủ ismeretanyag áll a tanulók/hallgatók rendelkezésére. Ugyanakkor fennáll egy másik lehetőség is. Éspedig: a tanulókkal ugyanazon problémát más-más módszerekkel megoldatjuk különböző évfolyamokon, majd - a nagyobb ismeretanyag birtokában összehasonlítás céljából visszatérünk a már megismert módszerekhez. Bármelyik megközelítést válasszuk is törekvésünk középpontjában a matematikai és módszertani ismeretanyag bővítése, a gondolkodás és a problémamegoldó képesség fejlesztése, s végül, de nem utolsósorban az új területek bemutatása, valamint az ahhoz kapcsolódó felfedezés öröme kell álljon. 


\section{Köszönetnyilvánítás}

Mindenekelőtt szüleimnek mondok köszönetet a nyugodt, szeretetteljes családi légkörért, amiben felnőttem és azért, hogy lehetővé tették, hogy továbbtanuljak.

Tisztelettel köszönöm témavezetőmnek, Dr. Kosztolányi Józsefnek azt a sokrétü (tudományos, szakmai és személyes) segítségét, tanácsait, támogatását és bátorítását, amelyben munkám során mindvégig részem volt. Nagyon sokat tanultam tőle.

Dr. Németh József írásaiból, előadásaiból és beszélgetéseinkből mind emberileg, mind szakmailag is gazdagabb lettem. Köszönet érte.

Köszönet illeti Dr. Gurzó Imrét, valamint Nagy Sándort a kézirat gondos átolvasásáért és a hozzáfüzött megjegyzésekért, javaslatokért.

A dolgozat végső formába öntésében segítettek: Dennis Engel, Priskin Gyula (angol nyelvü részek), Borbola Gábor (ábrák), Nagy Tiborné (technikai részek). Munkájukat köszönöm.

Köszönöm feleségem, Molnár Judit szerető gondoskodását, bátorítását, szakmai tanácsait, valamint gyermekeim, István és Réka türelmét és biztatását. Hálás vagyok az alkotó munkához szükséges nyugodt háttér megteremtéséért és a sok kedves, jó szóért. 


\section{Irodalomjegyzék}

\section{Könyvek, monográfiák}

[1] Ambrus András: Bevezetés a matematikadidaktikába, ELTE Eötvös Kiadó, Budapest, 1995

[2] Freud Róbert - Gyarmati Edit: Számelmélet, Nemzeti Tankönyvkiadó, Budapest, 2000

[3] Hajnal Péter: Összeszámlálási problémák, POLYGON Kiadó, Szeged, 1997

[4] Knuth, Donald E.: A számítógép-programozás müvészete 1, Müszaki Könyvkiadó, Budapest, 1994

[5] Neugebauer, Otto: Egzakt tudományok az ókorban, Gondolat Könyvkiadó, Budapest, 1984.

[6] Pólya György: A gondolkodás iskolája, Bibliotheca Kiadó, Budapest, 1957

[7] Pólya György: A problémamegoldás iskolája I., Tankönyvkiadó, Budapest, 1967

[8] Pólya György: A matematikai gondolkodás müvészete I., Gondolat Könyvkiadó, Budapest, 1988

[9] Sain Márton: Nincs királyi út!, Gondolat Könyvkiadó, Budapest, 1986

[10] Sirețchi, Gh.: Calcul diferențial şi integral I., Editura Ştiinţifică şi Enciclopedică, Bucureşti, 1985

[11] Szász Pál: A differenciál-és integrálszámítás elemei I., Typotex Kiadó, Budapest, 2000

[12] Szele Tibor: Bevezetés az algebrába, Tankönyvkiadó, Budapest, 1977

[13] Tomescu, Ioan: Kombinatorika és alkalmazásai, Műszaki Könyvkiadó, Budapest, 1978

[14] Tóth László: Kombinatorika, PTE TTK, Pécs, 2007

\section{Cikkek, tanulmányok}

[15] Acu, Dumitru: Egy új képlet az elsö $n$ természetes szám azonos hatványai összegének kiszámítására, Matematikai Lapok 8 (8/1985), 282-285

[16] Akiyama, Shigeki - Tanigawa, Yoshio: Multiple zeta values at non-positive integers, The Ramanujan Journal Vol. 5. No. 4. (2001), 327-351

[17] Bencze Mihály: About the sum $[\sqrt[k]{1}]^{p}+[\sqrt[k]{2}]^{p}+\ldots+[\sqrt[k]{n}]^{p}$, Octogon Mathematical Magazine, Vol. 9, No. 1A (2001), 126-135

[18] Kaneko, Masanobu: The Akiyama-Tanigawa algorithm for Bernoulli numbers, Journal of Integer Sequences, Vol. 3 (2000), Article 00.2.9.

[19] Kiss Sándor: Kísérlet az $1^{k}+2^{k}+3^{k}+\ldots+n^{k}$ összeg zárt alakban való elöállítására, Matlap 9 (2008/9), 327-330

[20] Konovalov, Sz.: Sorozatok metamorfózisai (orosz nyelven), Kvant No. 6 (1998) 24-26

[21] Molnár István: Pozitív racionális szám felbontása egyiptomi törtek összegére, A Matematika Tanítása 5 (2007), 19-22

[22] Molnár István: $A z x^{-n}+y^{-n}=z^{-n}$ egyenletröl, A Matematika Tanítása, 1 (2009), 3-9

[23] Molnár István: Egy ötlet: Alkalmazzuk a Catalan-összefüggést!, POLYGON, XVII/1-2 (2008), 125-133

[24] Molnár István: Egy ötlet: A Catalan-összefüggés általánositásai és a kapott formulák alkalmazásai, POLYGON, XIX/1 (2010), 63-75 
[25] Molnár, István: Some thoughts on a student survey, Teaching Mathematics and Computer Science, 8/1 (2010), 41-59

[26] Molnár István: The sum of the same powers of the first $n$ positive integers and the Bernoulli numbers, Teaching Mathematics and Computer Science (megjelenés alatt)

[27] Pengelley, David J.: The bridge between the continuous and the discrete via original sources, Study the Masters: The Abel-Fauvel Conference, Kristiansand, 2002

[28] Schultz, Henry J.: The Sum of the kth Powers of the First $n$ Integers, American Mathematical Monthly, 87 (1980), 478-481

\section{Probléma- és feladatgyüjtemények}

[29] Cucurezeanu, Ion: Probleme de aritmetică şi teoria numerelor, Editura Tehnică, Bucureşti, 1976

[30] Kántor Sándorné - Kántor Sándor: Nemzetközi magyar matematikai versenyek, Studium, Debrecen, 1999

[31] Kosztolányi József - Makay Géza - Pintér Klára - Pintér Lajos: Matematikai problémakalauz I., POLYGON Kiadó, Szeged, 1999

[32] Nelsen, Roger B.: Proofs Without Words: Exercises in Visual Thinking, Mathematical Association of America, Washington, 1993

[33] Popescu, Dragoş - Oboroceanu, George: Exerciții şi probleme de algebră, combinatorică şi teoria numerelor, Editura Didactică şi Pedagogică, Bucureşti, 1979

[34] Dobos Sándor - Reiman István: Nemzetközi matematikai diákolimpiák 1959-2003, Typotex Kiadó, Budapest, 2003

[35] Róka Sándor: 2000 feladat az elemi matematika köréböl, Typotex Kiadó, Budapest, 2000

[36] Scharnitzky Viktor: Egyetemi felvételi feladatok matematikából 1986-1995 Válogatás, Nemzeti Tankönyvkiadó, Budapest, 1996

[37] Sierpiński, Wacław: 200 feladat az elemi számelméletböl, Tankönyvkiadó, Budapest, 1972

[38] Skljarszki D.O. - Csencov N.N. - Jaglom I.M.: Válogatott feladatok és tételek az elemi matematika köréböl I., Typotex Kiadó, Budapest, 2000

[39] Tomescu, Ioan: Probleme de combinatorică şi teoria grafurilor, Editura Didactică şi Pedagogică, Bucureşti, 1981

[40] Trandafir, Rodica - Leonte, Alexandru: Culegere de probleme şi exerciţii de matematică, Editura Junimea, Iaşi, 1976

\section{Folyóiratok, internetes források}

[41] KöMaL 1996-2010

[42] Matlap (Matematikai Lapok) 1985-2010

[43] A Matematika Tanítása 2000-2010

[44] http://www.sztaki.hu/ keri/math/psum.htm

[45] http://en.wikipedia.org/wiki/Bernoulli_number

[46] http://mathworld.wolfram.com/PowerSum.html

[47] http://mathdl.maa.org/mathDL/46/?pa=content\&sa=viewDocument\&nodeId=3284

[48] http://seriesmathstudy.com/sms/finitealternativeodd 


\section{Összefoglalás}

Egy matematikai probléma megoldása során nagyon fontosak a módszerek. A célirányos módszerhasználat fontos tényező a sikerhez vezetö úton, így a hatványösszegzési feladatokban is.

A disszertáció témája az $S_{p}=1^{p}+2^{p}+3^{p}+\ldots+n^{p} \quad$ (ahol $p, n \in N, \quad n \geq 1$ ) összeg kiszámítása különböző matematikai módszerek alkalmazásával. Ezen belül egyfajta áttekintő összefoglalását adtuk a konkrét probléma történetének, a megoldás fejlődési aspektusainak. Hét különböző módszerrel kiszámítottuk az $S_{p}$-t és bemutattuk annak néhány konkrét esetét. Több esetben általánosításokat végeztünk az alternáló összegekre és a számtani sorozatokra, valamint kapcsolódásokat kerestünk más matematikai területek felé (Bell-, Stirling- és Bernoulli-számok). Ezen túlmenően 32 feladat közreadásával szándékoztunk illusztrálni a kapott képletek gyakorlati alkalmazhatóságát. A legfontosabb célunk az $S_{p}$ kiszámítása módszertanának átfogó jelleggel való tárgyalása, továbbá, hogy rövid értékelését adjuk az egyes módszerek előnyeinek, hátrányainak. Igyekeztünk azt is behatárolni, hogy mely módszerek használhatók fel a középiskolai oktatásban és melyek azok, amelyek inkább a felsőoktatás világába valók.

A munka során sokféle módszert alkalmaztunk. Ezek döntően matematikai módszerek (rekurzióra vezető, illetve nem rekurziós összefüggést adó metodikák), de felhasználtunk egyéb módszereket is (forrásfeldolgozás, ezen belül értékelés, elemzés és összehasonlítás, valamint ábrázolástechnikai módszerek).

Az értekezés második fejezetében áttekintettük, hogy az egyes korok matematikusai meddig jutottak el az $S_{p}$ kiszámítása tekintetében. Elsőként az ókori görögök értek el több részeredményt, lényegében a figurális számok felhasználásával. A források szerint a kínai, a hindu és az arab-perzsa matematikusok is komoly ismeretek birtokában voltak a számtani sorozatokkal, valamint a négyzet-, illetve köbszámok összegzésével kapcsolatban. A problémát a matematikai gondolkodás egy hosszabb fejlődési folyamata során a középkori és kora újkori európai gondolkodók oldották meg (Thomas Harriot, Johann Faulhaber, Pierre de Fermat, Blaise Pascal, Jacob Bernoulli).

A harmadik fejezetben öt rekurzióra vezető módszert mutattunk be.

- Az elsőben a megoldást egy mátrixos (táblázatos elrendezésü) módszerrel kerestük, ahol mátrixaritmetikai ismereteket is felhasználtunk. Egy speciális mátrixot írtunk fel, melynek elemeit kétféleképpen összegeztük. A kapott rekurziós formula:

$$
S_{p}=(n+1) \cdot S_{p-1}-\sum_{k=1}^{n} S_{k ; p-1} .
$$

Levezettük az alternáló összeg $-S_{p}^{*}=1^{p}-2^{p}+3^{p}-4^{p}+\ldots+(-1)^{n-1} \cdot n^{p}-$ rekurziós képletét is. Ennek alakja:

$$
S_{p}^{*}=(n+1) \cdot S_{p-1}^{*}-\sum_{k=1}^{n} S_{k ; p-1}^{*} \cdot
$$

Elvégeztük a kiinduló mátrix (táblázat) elemeinek „lépcsős” összegzését is, s így mátrixaritmetikai fogalmak használata nélkül juthattunk el az elöbbiekben megismert összefüggéshez. 
- Megoldottuk a problémát egy speciális azonosságból, jelesül a

$$
\begin{aligned}
& (k+1) \cdot k^{p}-k \cdot(k-1)^{p}= \\
& =(p+1) \cdot k^{p}-\left(\begin{array}{l}
p \\
2
\end{array}\right) \cdot k^{p-1}+\left(\begin{array}{l}
p \\
3
\end{array}\right) \cdot k^{p-2}-\left(\begin{array}{l}
p \\
4
\end{array}\right) \cdot k^{p-3}+\ldots+(-1)^{p+1} \cdot\left(\begin{array}{l}
p \\
p
\end{array}\right) \cdot k
\end{aligned}
$$

egyenlőségből kiindulva ( $\left.k \in R, p \in Z^{+}\right)$.

Ennél a megoldásánál a számítások után a rekurziós összefüggésre adódott, hogy

$$
(p+1) \cdot S_{p}=(n+1) n^{p}+\left(\begin{array}{l}
p \\
2
\end{array}\right) \cdot S_{p-1}-\left(\begin{array}{l}
p \\
3
\end{array}\right) \cdot S_{p-2}+\ldots+(-1)^{p} \cdot\left(\begin{array}{l}
p \\
p
\end{array}\right) \cdot S_{1} .
$$

A rekurzióhoz vezető gondolatmenethez hasonló úton két másik összefüggésből kiindulva összegképletek közötti összefüggéseket határoztunk meg a páratlan, illetve a páros kitevők esetére.

- A kitüzött feladat elvégezhető a legismertebb módszerrel, a binomiális tétel felhasználásával is. Itt a kiinduló összefüggés:

$$
(a+1)^{p+1}-a^{p+1}=\left(\begin{array}{c}
p+1 \\
1
\end{array}\right) \cdot a^{p}+\left(\begin{array}{c}
p+1 \\
2
\end{array}\right) \cdot a^{p-1}+\ldots+\left(\begin{array}{c}
p+1 \\
p
\end{array}\right) \cdot a+\left(\begin{array}{c}
p+1 \\
p+1
\end{array}\right), \text { ahol } a \in R .
$$

Az $a$ helyébe behelyettesítve az 1,2,..,n számokat, a kapott összefüggéseket összegezve, valamint a szükséges részletszámításokat elvégezve adódik, hogy:

$$
(p+1) \cdot S_{p}=(n+1)^{p+1}-\left(\begin{array}{c}
p+1 \\
2
\end{array}\right) \cdot S_{p-1}-\ldots-\left(\begin{array}{c}
p+1 \\
p
\end{array}\right) \cdot S_{1}-\left(\begin{array}{c}
p+1 \\
p+1
\end{array}\right) \cdot(n+1) .
$$

Hasonló eljárással általánosítottunk a számtani sorozat első $n$ tagja $p$-edik hatványának összege, azaz az

$$
S_{p}(a, d)=a_{1}^{p}+a_{2}^{p}+a_{3}^{p}+\ldots+a_{n}^{p}=\sum_{i=1}^{n}[a+(i-1) \cdot d]^{p}
$$

esetére, ahol $a$ a sorozat első eleme, míg $d$ a sorozat differenciája. A kapott rekurzió:

$$
(p+1) \cdot d \cdot S_{p}(a, d)=(a+n d)^{p+1}-a^{p+1}-\sum_{k=2}^{p+1} d^{k} \cdot\left(\begin{array}{c}
p+1 \\
k
\end{array}\right) \cdot S_{p+1-k}(a, d) .
$$

Kidolgoztuk a megoldást az első $n$ pozitív egész szám $p$-edik hatványa alternáló összegére is. Itt a végső formula:

$$
\begin{aligned}
& 2 \cdot(p+1) \cdot S_{p}^{*}= \\
& =(-1)^{n-1} \cdot\left[(n+2)^{p+1}-(n+1)^{p+1}-2^{p}\right]+2^{p}-1-\sum_{k=2}^{p}\left(\begin{array}{c}
p+1 \\
k
\end{array}\right) \cdot S_{p+1-k}^{*} \cdot 2^{k} .
\end{aligned}
$$

Elvégeztük az általánosítást a számtani sorozat alternáló összegére is. Ekkor a rekurziós összefüggés felírható az alábbiak szerint:

$$
\begin{aligned}
& 2 d \cdot(p+1) \cdot S_{p}^{*}(a, d)=(-1)^{n-1} \cdot\left[a_{n+2}^{p+1}-a_{n+1}^{p+1}-d \cdot(2 d)^{p}\right]+ \\
& +a_{2}^{p+1}-a_{1}^{p+1}-d \cdot(2 d)^{p}-\sum_{k=2}^{p}\left(\begin{array}{c}
p+1 \\
k
\end{array}\right) \cdot S_{p+1-k}^{*}(a, d) \cdot(2 d)^{k} .
\end{aligned}
$$


- Az összegzés elvégezhető a szimmetrikus összegek segítségével is. Ehhez bevezettük az emelkedő és süllyedő faktoriálisok fogalmát. Az emelkedő faktoriálishoz egy sorozatot rendeltünk, melynek tagjai között rekurziós kapcsolatot teremtettünk, majd az adott sorozat tagjait összegeztük. A kapott teleszkópikus összeg eredményével és az $1,2, \ldots,(p-1)$ számokhoz rendelt $s_{1}, s_{2}, \ldots, s_{p-1}$ szimmetrikus összegek segítségével megkaptuk a keresett rekurziós formulát, melynek alakja:

$$
S_{p}=\frac{n(n+1)(n+2) \ldots(n+p)}{p+1}-\sum_{i=1}^{p-1} s_{i} \cdot S_{p-i} .
$$

Bevezettük a Bell- és Stirling-számokat, rekurziós összefüggéseket írtunk fel közöttük. Kapcsolatot teremtettünk többek között az emelkedő/süllyedő faktoriális, a Stirlingszámok, valamint az $x$ határozatlan pozitív egész kitevőjü hatványai között. Megadtuk az első $n$ pozitív egész szám reciprokainak összegét az elsőfajú Stirling-számok segítségével, majd ismertettük a Catalan-összefüggést.

- A probléma megoldható a differenciálszámítás felhasználásával is. Itt az

$$
\left(e^{x}-1\right) \cdot F_{n}(x)=e^{(n+1) \cdot x}-e^{x}
$$

összefüggésből indultunk ki, ahol $F_{n}(x)=\sum_{l=1}^{n} e^{l \cdot x}, n \in Z^{+}$.

Felírva az összefüggés mindkét oldalának $(p+1)$-edrendủ deriváltját, majd $x$ helyébe 0 -át írva és a szükséges számításokat elvégezve, eredményül a binomiális módszer esetén már megismert eredményt kaptuk, éspedig:

$$
(p+1) \cdot S_{p}=(n+1)^{p+1}-\left(\begin{array}{c}
p+1 \\
2
\end{array}\right) \cdot S_{p-1}-\ldots-\left(\begin{array}{c}
p+1 \\
p
\end{array}\right) \cdot S_{1}-\left(\begin{array}{c}
p+1 \\
p+1
\end{array}\right) \cdot(n+1) .
$$

Általánosítottunk a számtani sorozatok esetére. Ekkor az $F_{n}(x)=\sum_{l=1}^{n} e^{a_{l} \cdot x}$ függvényt használtuk fel, s a számítások végén a következő eredményre jutottunk:

$$
\begin{aligned}
& (p+1) \cdot d \cdot S_{p}(a, d)=(a+n d)^{p+1}-a^{p+1}-\left(\begin{array}{c}
p+1 \\
2
\end{array}\right) \cdot d^{2} \cdot S_{p-1}(a, d)- \\
& -\left(\begin{array}{c}
p+1 \\
3
\end{array}\right) \cdot d^{3} \cdot S_{p-2}(a, d)-\ldots-\left(\begin{array}{c}
p+1 \\
p
\end{array}\right) \cdot d^{p} \cdot S_{1}(a, d)-\left(\begin{array}{c}
p+1 \\
p+1
\end{array}\right) \cdot d^{p+1} \cdot S_{0}(a, d) .
\end{aligned}
$$

Az általánosítást elvégeztük az első $n$ pozitív egész szám $p$-edik hatványa váltakozó előjelü összegére, majd a számtani sorozat alternáló összegére is.

$\mathrm{Az}$ első $n$ pozitív egész szám $p$-edik hatványa alternáló összegére az $F_{n}(x)=\sum_{l=1}^{n}(-1)^{l-1} \cdot e^{l \cdot x}$ függvény segítségével írtuk fel a rekurziót, amelynek alakja:

$$
\begin{aligned}
& 2 \cdot(p+1) \cdot S_{p}^{*}= \\
& =(-1)^{n-1} \cdot\left[(n+2)^{p+1}-(n+1)^{p+1}-2^{p}\right]+2^{p}-1-\sum_{k=2}^{p}\left(\begin{array}{c}
p+1 \\
k
\end{array}\right) \cdot S_{p+1-k}^{*} \cdot 2^{k} .
\end{aligned}
$$

A számtani sorozat alternáló összege esetében pedig a kiinduló speciális függvény az $F_{n}(x)=\sum_{l=1}^{n}(-1)^{l-1} \cdot e^{a_{l} \cdot x}, \mathrm{~s}$ a rekurziós képlet pedig a következö: 


$$
\begin{aligned}
& 2 d \cdot(p+1) \cdot S_{p}^{*}(a, d)=(-1)^{n-1} \cdot\left[a_{n+2}^{p+1}-a_{n+1}^{p+1}-d \cdot(2 d)^{p}\right]+ \\
& +a_{2}^{p+1}-a_{1}^{p+1}-d \cdot(2 d)^{p}-\sum_{k=2}^{p}\left(\begin{array}{c}
p+1 \\
k
\end{array}\right) \cdot S_{p+1-k}^{*}(a, d) \cdot(2 d)^{k} .
\end{aligned}
$$

A negyedik fejezet a nem rekurzióra vezető két megoldási módszert taglalja. Ezek a módszerek azért nagyon hasznosak, mert a probléma azonnali megoldására vezetnek, ezeknél nincs szükség az adott $p$-nél kisebb kitevőkre felírt összegekre.

- Az összegzési probléma megoldható a differenciasorozatok felhasználásával. Ehhez értelmeztük a differenciasorozat fogalmát, majd definiáltuk mit értünk $p$-edrendủ számtani sorozaton. Bebizonyítottuk, hogy bármely $p$-edrendủ számtani sorozat $k$-adik tagja $k$-nak egy $p$-edfokú polinomjával adható meg. $\sigma_{n ; p}$-vel jelölve a $p$-edrendü számtani sorozat első $n$ tagjának összegét, megadtuk $\sigma_{n ; p}$-t az egymás után következő differenciasorozatok kezdő tagjainak $\left(a_{1} ; \Delta a_{1} ; \Delta^{2} a_{1} ; \ldots ; \Delta^{p} a_{1}\right)$ segítségével a következőképpen:

$$
\sigma_{n ; p}=\left(\begin{array}{l}
n \\
1
\end{array}\right) \cdot a_{1}+\left(\begin{array}{l}
n \\
2
\end{array}\right) \cdot \Delta a_{1}+\left(\begin{array}{l}
n \\
3
\end{array}\right) \cdot \Delta^{2} a_{1}+\ldots+\left(\begin{array}{c}
n \\
p+1
\end{array}\right) \cdot \Delta^{p} a_{1} .
$$

- A második nem rekurziós módszer lineáris algebrai eszközöket használ fel. E módszernél a binomiális tétel segítségével előállított metodikához hasonló gondolatmenet alapján jutottunk el a következő összefüggéshez $(k \in N)$ :

$$
(n+1)^{k+1}=\left(\begin{array}{c}
k+1 \\
k+1
\end{array}\right) \cdot(n+1)+\left(\begin{array}{c}
k+1 \\
k
\end{array}\right) \cdot S_{1}+\ldots+\left(\begin{array}{c}
k+1 \\
2
\end{array}\right) \cdot S_{k-1}+\left(\begin{array}{c}
k+1 \\
1
\end{array}\right) \cdot S_{k} \cdot
$$

A kapott relációhoz hozzárendeltünk egy speciális lineáris egyenletrendszert, melyet úgy kaptunk, hogy a $k$ helyére rendre behelyettesítettük a $0,1,2, \ldots, p$ értékeket. Az így kapott $(p+1)$ egyenletböl álló egyenletrendszerben ismeretleneknek tekintettük az $S_{1}, S_{2}, \ldots, S_{p}$ „szimbólumokat” és bebizonyítottuk, hogy a lineáris egyenletrendszer a Cramer-szabállyal megoldható.

Így $S_{p}$-re a következő formulát kaptuk:

$$
S_{p}=\frac{1}{(p+1) !} \cdot\left|\begin{array}{lccccc}
\left(\begin{array}{l}
1 \\
1
\end{array}\right) & 0 & 0 & \ldots & 0 & n+1 \\
\left(\begin{array}{l}
2 \\
2
\end{array}\right) & \left(\begin{array}{l}
2 \\
1
\end{array}\right) & 0 & \ldots & 0 & (n+1)^{2} \\
\left(\begin{array}{l}
3 \\
3
\end{array}\right) & \left(\begin{array}{l}
3 \\
2
\end{array}\right) & \left(\begin{array}{l}
3 \\
1
\end{array}\right) & \ldots & 0 & (n+1)^{3} \\
--- & --- & --- & --- & --- & --- \\
\left(\begin{array}{l}
p \\
p
\end{array}\right) & \left(\begin{array}{c}
p \\
p-1
\end{array}\right) & \left(\begin{array}{c}
p \\
p-2
\end{array}\right) & \cdots & \left(\begin{array}{c}
p \\
1
\end{array}\right) & (n+1)^{p} \\
\left(\begin{array}{l}
p+1 \\
p+1
\end{array}\right) & \left(\begin{array}{c}
p+1 \\
p
\end{array}\right) & \left(\begin{array}{c}
p+1 \\
p-1
\end{array}\right) & \cdots & \left(\begin{array}{c}
p+1 \\
2
\end{array}\right) & (n+1)^{p+1}
\end{array}\right| .
$$

Elvégeztük a feladat általánosítását ezzel a módszerrel számtani sorozatokra is. Ekkor a kapott formula az alábbi: 


$$
S_{p}(a, d)=\frac{1}{(p+1) ! d^{p+1}} \cdot D_{p}^{\prime}
$$

ahol

$$
D_{p}^{\prime}=\left|\begin{array}{ccccc}
\left(\begin{array}{l}
1 \\
1
\end{array}\right) \cdot d & 0 & \ldots & 0 & (a+n d)^{1}-a^{1} \\
\left(\begin{array}{l}
2 \\
2
\end{array}\right) \cdot d^{2} & \left(\begin{array}{l}
2 \\
1
\end{array}\right) \cdot d & \ldots & 0 & (a+n d)^{2}-a^{2} \\
\left(\begin{array}{l}
3 \\
3
\end{array}\right) \cdot d^{3} & \left(\begin{array}{l}
3 \\
2
\end{array}\right) \cdot d^{2} & \ldots & 0 & (a+n d)^{3}-a^{3} \\
----- & ----- & --- & ----- & ----- \\
\left(\begin{array}{l}
p \\
p
\end{array}\right) \cdot d^{p} & \left(\begin{array}{c}
p \\
p-1
\end{array}\right) \cdot d^{p-1} & \ldots & \left(\begin{array}{c}
p \\
1
\end{array}\right) \cdot d & (a+n d)^{p}-a^{p} \\
\left(\begin{array}{l}
p+1 \\
p+1
\end{array}\right) \cdot d^{p+1} & \left(\begin{array}{c}
p+1 \\
p
\end{array}\right) \cdot d^{p} & \ldots & \left(\begin{array}{c}
p+1 \\
2
\end{array}\right) \cdot d^{2} & (a+n d)^{p+1}-a^{p+1}
\end{array}\right| .
$$

A módszer alkalmazható a Bernoulli-számok kiszámítására is. A $(p+1)$-edik Bernoulliszám alakja:

$$
B_{p}=\frac{1}{(p+1) !} \cdot\left|\begin{array}{cccccc}
\left(\begin{array}{l}
1 \\
1
\end{array}\right) & 0 & 0 & \cdots & 0 & 1 \\
\left(\begin{array}{l}
2 \\
2
\end{array}\right) & \left(\begin{array}{l}
2 \\
1
\end{array}\right) & 0 & \cdots & 0 & 0 \\
\left(\begin{array}{l}
3 \\
3
\end{array}\right) & \left(\begin{array}{l}
3 \\
2
\end{array}\right) & \left(\begin{array}{l}
3 \\
1
\end{array}\right) & \cdots & 0 & 0 \\
--- & --- & --- & -- & --- & --- \\
\left(\begin{array}{l}
p \\
p
\end{array}\right) & \left(\begin{array}{c}
p \\
p-1
\end{array}\right) & \left(\begin{array}{c}
p \\
p-2
\end{array}\right) & \cdots & \left(\begin{array}{c}
p \\
1
\end{array}\right) & 0 \\
\left(\begin{array}{l}
p+1 \\
p+1
\end{array}\right) & \left(\begin{array}{c}
p+1 \\
p
\end{array}\right) & \left(\begin{array}{c}
p+1 \\
p-1
\end{array}\right) & \cdots & \left(\begin{array}{c}
p+1 \\
2
\end{array}\right) & 0
\end{array}\right| .
$$

Összefüggéseket mutattunk be a Stirling-számok és a Bernoulli-számok között, illetve bebizonyítottuk az első $n$ pozitív egész szám $p$-edik hatványának összege és a Bernoulliszámok közti kapcsolatot, amely a következő:

$$
S_{p}=\frac{1}{p+1} \cdot \sum_{k=0}^{p}\left(\begin{array}{c}
p+1 \\
k
\end{array}\right) \cdot B_{k} \cdot(n+1)^{p+1-k} .
$$

A munka összegzéssel zárul, illetve a disszertáció függelékében több feladatban megmutatjuk a hatványösszegzési képletek alkalmazhatóságát különböző példamegoldási típusokban. Ezek nagy része bemutatható a középiskolai oktatás keretében is. 


\section{Summary}

Methods are very important in solving mathematical problems. A purpose-driven use of methods is an important factor on the road to success and in exercises about the sums of powers as well.

The dissertation is about calculating the sum of $S_{p}=1^{p}+2^{p}+3^{p}+\ldots+n^{p}$ (where $p, n \in N$, $n \geq 1$ ) with the application of different mathematical methods. Within this we have given a sort of overview of the history of the particular problem and of the developmental aspects of its solution. We have calculated $S_{p}$ via seven different methods and presented some concrete examples. In several cases we have made generalizations for the alternating sums and arithmetic progressions, and have sought connections with other mathematical areas (Bell, Stirling, and Bernoulli numbers). Beyond this we have intended to illustrate the practical applicability of the obtained formulas by presenting 32 exercises. Our main objective is to discuss the methodology of calculating $S_{p}$ comprehensively, and to give a short assessment of the advantages and disadvantages of each method. We have also tried to ascertain which methods can be used in secondary education, and which ones are more apt to be relied upon in higher education.

During our work we have used many different methods. These are mainly mathematical ones (methods resulting in recursive and non-recursive relations), but we have also used other methods as well (presentation of sources, and within this, evaluation, analysis, and comparison, and also illustration methods).

In the second chapter of the dissertation we have examined how far the mathematicians of different periods advanced in calculating $S_{p}$. First the ancient Greeks came to know some partial results, essentially through the use of figurate numbers. According to the sources, the Chinese, Hindu, and Arabo-Persian mathematicians also had deep insights into arithmetic sequences, and into the sums of squares and cubes. Then the problem was solved by mediaeval and early modern thinkers during a longer developmental phase of mathematical thought (Thomas Harriot, Johann Faulhaber, Pierre de Fermat, Blaise Pascal, Jacob Bernoulli).

In chapter three we have presented five recursive methods.

- In the case of the first one we have looked for the solution through a matrix method (tabulation), where we have also leaned on the knowledge of matrix artihmetic. We have drawn up a special matrix and summed up its elements in two ways. The obtained recursive formula is:

$$
S_{p}=(n+1) \cdot S_{p-1}-\sum_{k=1}^{n} S_{k ; p-1} \cdot
$$

We have also obtained the recursive formula for the alternating sum, $S_{p}^{*}=1^{p}-2^{p}+3^{p}-4^{p}+\ldots+(-1)^{n-1} \cdot n^{p}$, the form of which is:

$$
S_{p}^{*}=(n+1) \cdot S_{p-1}^{*}-\sum_{k=1}^{n} S_{k ; p-1}^{*} .
$$

We have also done the 'staircase-like' summing of the elements of the initial matrix (table), and thus we could get the above formula without using the concepts of matrix arithmetic. 
- We have solved the problem starting from a special identity, namely the identity

$$
\begin{aligned}
& (k+1) \cdot k^{p}-k \cdot(k-1)^{p}= \\
& =(p+1) \cdot k^{p}-\left(\begin{array}{l}
p \\
2
\end{array}\right) \cdot k^{p-1}+\left(\begin{array}{l}
p \\
3
\end{array}\right) \cdot k^{p-2}-\left(\begin{array}{l}
p \\
4
\end{array}\right) \cdot k^{p-3}+\ldots+(-1)^{p+1} \cdot\left(\begin{array}{l}
p \\
p
\end{array}\right) \cdot k
\end{aligned}
$$

Here the calculations led to the recursive relation

$$
(p+1) \cdot S_{p}=(n+1) n^{p}+\left(\begin{array}{l}
p \\
2
\end{array}\right) \cdot S_{p-1}-\left(\begin{array}{l}
p \\
3
\end{array}\right) \cdot S_{p-2}+\ldots+(-1)^{p} \cdot\left(\begin{array}{l}
p \\
p
\end{array}\right) \cdot S_{1} .
$$

Similar to the way of thinking that led to recursion and starting from two other relations, we have established relations between summing formulas for odd and even exponents.

- Solving the problem at hand can also be done by the best-known method, the binomial theorem. Now the starting point is:

$$
(a+1)^{p+1}-a^{p+1}=\left(\begin{array}{c}
p+1 \\
1
\end{array}\right) \cdot a^{p}+\left(\begin{array}{c}
p+1 \\
2
\end{array}\right) \cdot a^{p-1}+\ldots+\left(\begin{array}{c}
p+1 \\
p
\end{array}\right) \cdot a+\left(\begin{array}{c}
p+1 \\
p+1
\end{array}\right), \text { where } a \in R .
$$

Substituting $a$ with $1,2, \ldots, n$ summing up the relations, and doing the necessary calculations, we get that

$$
(p+1) \cdot S_{p}=(n+1)^{p+1}-\left(\begin{array}{c}
p+1 \\
2
\end{array}\right) \cdot S_{p-1}-\ldots-\left(\begin{array}{c}
p+1 \\
p
\end{array}\right) \cdot S_{1}-\left(\begin{array}{c}
p+1 \\
p+1
\end{array}\right) \cdot(n+1) .
$$

With a similar method we have made a generalization for the

$$
S_{p}(a, d)=a_{1}^{p}+a_{2}^{p}+a_{3}^{p}+\ldots+a_{n}^{p}=\sum_{i=1}^{n}[a+(i-1) \cdot d]^{p}
$$

case of arithmetic progression, where $a$ is the first term of the progression, while $d$ is the differential. Thus we get this recursion:

$$
(p+1) \cdot d \cdot S_{p}(a, d)=(a+n d)^{p+1}-a^{p+1}-\sum_{k=2}^{p+1} d^{k} \cdot\left(\begin{array}{c}
p+1 \\
k
\end{array}\right) \cdot S_{p+1-k}(a, d) .
$$

We have also worked out the solution for the alternating sum of the $p$ th power of the first $n$ positive integers, where the final formula is:

$$
\begin{aligned}
& 2 \cdot(p+1) \cdot S_{p}^{*}= \\
& =(-1)^{n-1} \cdot\left[(n+2)^{p+1}-(n+1)^{p+1}-2^{p}\right]+2^{p}-1-\sum_{k=2}^{p}\left(\begin{array}{c}
p+1 \\
k
\end{array}\right) \cdot S_{p+1-k}^{*} \cdot 2^{k} .
\end{aligned}
$$

We have made a generalization for the alternating sum of arithmetic progression. Here the recursive pattern can be described as follows:

$$
\begin{aligned}
& 2 d \cdot(p+1) \cdot S_{p}^{*}(a, d)=(-1)^{n-1} \cdot\left[a_{n+2}^{p+1}-a_{n+1}^{p+1}-d \cdot(2 d)^{p}\right]+ \\
& +a_{2}^{p+1}-a_{1}^{p+1}-d \cdot(2 d)^{p}-\sum_{k=2}^{p}\left(\begin{array}{c}
p+1 \\
k
\end{array}\right) \cdot S_{p+1-k}^{*}(a, d) \cdot(2 d)^{k} .
\end{aligned}
$$

- Summing can also be done with the help of symmetric sums. For this we have introduced the concepts of rising and falling factorials. We have assigned a sequence to the rising 
factorial and established a recursive relation between its terms, and then summed up the terms of the given sequence. With the result of the obtained telescopic sum and the $s_{1}, s_{2}, \ldots, s_{p-1}$ symmetric sums assigned to the $1,2, \ldots,(p-1)$ numbers, we have obtained the pursued recursive formula:

$$
S_{p}=\frac{n(n+1)(n+2) \ldots(n+p)}{p+1}-\sum_{i=1}^{p-1} s_{i} \cdot S_{p-i} .
$$

We have introduced the Bell and Stirling numbers, and drawn up recursive relations between them. We have established a connection, among others, between the rising/falling factorial, the Stirling numbers, and the powers of $x$ with indefinite positive integer exponents. We have given the reciprocal sum of the first $n$ positive integers with the help of the Stirling numbers of the first kind, and then described the Catalan relation.

- The problem can also be solved with differential calculus. Here we have started from the relation that

$$
\left(e^{x}-1\right) \cdot F_{n}(x)=e^{(n+1) \cdot x}-e^{x},
$$

where $F_{n}(x)=\sum_{l=1}^{n} e^{l \cdot x}, n \in Z^{+}$.

If we derive both sides to rank $(p+1)$, put 0 in the place of $x$, and then make the necessary calculations, we will arrive at the same result that we determined using the binomial method, that is:

$$
(p+1) \cdot S_{p}=(n+1)^{p+1}-\left(\begin{array}{c}
p+1 \\
2
\end{array}\right) \cdot S_{p-1}-\ldots-\left(\begin{array}{c}
p+1 \\
p
\end{array}\right) \cdot S_{1}-\left(\begin{array}{c}
p+1 \\
p+1
\end{array}\right) \cdot(n+1) .
$$

We have made a generalization for arithmetic progression. In this case we used the function $F_{n}(x)=\sum_{l=1}^{n} e^{a_{l} \cdot x}$, and at the end of the calculations we had the following result:

$$
\begin{aligned}
& (p+1) \cdot d \cdot S_{p}(a, d)=(a+n d)^{p+1}-a^{p+1}-\left(\begin{array}{c}
p+1 \\
2
\end{array}\right) \cdot d^{2} \cdot S_{p-1}(a, d)- \\
& -\left(\begin{array}{c}
p+1 \\
3
\end{array}\right) \cdot d^{3} \cdot S_{p-2}(a, d)-\ldots-\left(\begin{array}{c}
p+1 \\
p
\end{array}\right) \cdot d^{p} \cdot S_{1}(a, d)-\left(\begin{array}{c}
p+1 \\
p+1
\end{array}\right) \cdot d^{p+1} \cdot S_{0}(a, d) .
\end{aligned}
$$

We have also made the generalization for the alternating sum of the $p$ th power of the first $n$ positive integers, and then for the alternating sum of arithmetic progression.

For the alternating sum of the $p$ th power of the first $n$ positive integers we have established recursion with the help of the function $F_{n}(x)=\sum_{l=1}^{n}(-1)^{l-1} \cdot e^{l \cdot x}$, which led to:

$$
\begin{aligned}
& 2 \cdot(p+1) \cdot S_{p}^{*}= \\
& =(-1)^{n-1} \cdot\left[(n+2)^{p+1}-(n+1)^{p+1}-2^{p}\right]+2^{p}-1-\sum_{k=2}^{p}\left(\begin{array}{c}
p+1 \\
k
\end{array}\right) \cdot S_{p+1-k}^{*} \cdot 2^{k} .
\end{aligned}
$$

As for the alternating sum of arithmetic progression, the initial special function is $F_{n}(x)=\sum_{l=1}^{n}(-1)^{l-1} \cdot e^{a_{l} \cdot x}$, while the recursive formula is the following: 


$$
\begin{aligned}
& 2 d \cdot(p+1) \cdot S_{p}^{*}(a, d)=(-1)^{n-1} \cdot\left[a_{n+2}^{p+1}-a_{n+1}^{p+1}-d \cdot(2 d)^{p}\right]+ \\
& +a_{2}^{p+1}-a_{1}^{p+1}-d \cdot(2 d)^{p}-\sum_{k=2}^{p}\left(\begin{array}{c}
p+1 \\
k
\end{array}\right) \cdot S_{p+1-k}^{*}(a, d) \cdot(2 d)^{k} .
\end{aligned}
$$

The fourth chapter discusses the two non-recursive methods. These methods are very useful because they lead to the immediate solution of the problem, and there is no need for the sums generated by exponents that are smaller than the given $p$.

- The summing problem can be solved by using differential sequences. For this we have interpreted the concept of the differential sequence, and then defined what we mean by arithmetic progression of order $p$. We have proved that the $k$ th term of any arithmetic progression of order $p$ can be given with the $p$ th polynomial of $k$. Denoting the sum of the first $n$ terms of the arithmetic progression of order $p$ with $\sigma_{n ; p}$, we have defined $\sigma_{n ; p}$ with the help of the first terms $\left(a_{1} ; \Delta a_{1} ; \Delta^{2} a_{1} ; \ldots ; \Delta^{p} a_{1}\right)$ of the consecutive differential sequences in the following way:

$$
\sigma_{n ; p}=\left(\begin{array}{l}
n \\
1
\end{array}\right) \cdot a_{1}+\left(\begin{array}{l}
n \\
2
\end{array}\right) \cdot \Delta a_{1}+\left(\begin{array}{l}
n \\
3
\end{array}\right) \cdot \Delta^{2} a_{1}+\ldots+\left(\begin{array}{c}
n \\
p+1
\end{array}\right) \cdot \Delta^{p} a_{1} .
$$

- The second non-recursive method uses linear algebraic means. With this method, following a similar train of thought to the methodology prompted by the binomial theorem, we have arrived at the following relation $(k \in N)$ :

$$
(n+1)^{k+1}=\left(\begin{array}{c}
k+1 \\
k+1
\end{array}\right) \cdot(n+1)+\left(\begin{array}{c}
k+1 \\
k
\end{array}\right) \cdot S_{1}+\ldots+\left(\begin{array}{c}
k+1 \\
2
\end{array}\right) \cdot S_{k-1}+\left(\begin{array}{c}
k+1 \\
1
\end{array}\right) \cdot S_{k} .
$$

We have assigned a special linear system of equations to the obtained relation, which we got by substituting in turns the values $0,1,2, \ldots, p$ into $k$. In the resulting system of equations, consisting of $(p+1)$ equations, we have considered the 'symbols' $S_{1}, S_{2}, \ldots, S_{p}$ as unknowns, and proved that the linear system of equations could be solved with Cramer's rule.

Thus we got the following formula for $S_{p}$ :

$$
S_{p}=\frac{1}{(p+1) !} \cdot\left|\begin{array}{cccccc}
\left(\begin{array}{l}
1 \\
1
\end{array}\right) & 0 & 0 & \ldots & 0 & n+1 \\
\left(\begin{array}{l}
2 \\
2
\end{array}\right) & \left(\begin{array}{l}
2 \\
1
\end{array}\right) & 0 & \ldots & 0 & (n+1)^{2} \\
\left(\begin{array}{l}
3 \\
3
\end{array}\right) & \left(\begin{array}{l}
3 \\
2
\end{array}\right) & \left(\begin{array}{l}
3 \\
1
\end{array}\right) & \ldots & 0 & (n+1)^{3} \\
--- & --- & --- & --- & --- & --- \\
\left(\begin{array}{l}
p \\
p
\end{array}\right) & \left(\begin{array}{c}
p \\
p-1
\end{array}\right) & \left(\begin{array}{c}
p \\
p-2
\end{array}\right) & \cdots & \left(\begin{array}{c}
p \\
1
\end{array}\right) & (n+1)^{p} \\
\left(\begin{array}{l}
p+1 \\
p+1
\end{array}\right) & \left(\begin{array}{c}
p+1 \\
p
\end{array}\right) & \left(\begin{array}{c}
p+1 \\
p-1
\end{array}\right) & \cdots & \left(\begin{array}{c}
p+1 \\
2
\end{array}\right) & (n+1)^{p+1}
\end{array}\right| .
$$

We have also generalized the problem with this method for arithmetic progression. Here the formula is: 


$$
S_{p}(a, d)=\frac{1}{(p+1) ! d^{p+1}} \cdot D_{p}^{\prime},
$$

where

$$
D_{p}^{\prime}=\left|\begin{array}{ccccc}
\left(\begin{array}{l}
1 \\
1
\end{array}\right) \cdot d & 0 & \ldots & 0 & (a+n d)^{1}-a^{1} \\
\left(\begin{array}{l}
2 \\
2
\end{array}\right) \cdot d^{2} & \left(\begin{array}{l}
2 \\
1
\end{array}\right) \cdot d & \ldots & 0 & (a+n d)^{2}-a^{2} \\
\left(\begin{array}{l}
3 \\
3
\end{array}\right) \cdot d^{3} & \left(\begin{array}{l}
3 \\
2
\end{array}\right) \cdot d^{2} & \ldots & 0 & (a+n d)^{3}-a^{3} \\
---- & ---- & --- & ----- & ----- \\
\left(\begin{array}{l}
p \\
p
\end{array}\right) \cdot d^{p} & \left(\begin{array}{c}
p \\
p-1
\end{array}\right) \cdot d^{p-1} & \ldots & \left(\begin{array}{c}
p \\
1
\end{array}\right) \cdot d & (a+n d)^{p}-a^{p} \\
\left(\begin{array}{l}
p+1 \\
p+1
\end{array}\right) \cdot d^{p+1} & \left(\begin{array}{c}
p+1 \\
p
\end{array}\right) \cdot d^{p} & \ldots & \left(\begin{array}{c}
p+1 \\
2
\end{array}\right) \cdot d^{2} & (a+n d)^{p+1}-a^{p+1}
\end{array}\right| .
$$

The method can also be applied to calculate Bernoulli numbers. The formula for the $(p+1)$ th Bernoulli number is:

$$
B_{p}=\frac{1}{(p+1) !} \cdot\left|\begin{array}{cccccc}
\left(\begin{array}{l}
1 \\
1
\end{array}\right) & 0 & 0 & \ldots & 0 & 1 \\
\left(\begin{array}{l}
2 \\
2
\end{array}\right) & \left(\begin{array}{l}
2 \\
1
\end{array}\right) & 0 & \ldots & 0 & 0 \\
\left(\begin{array}{l}
3 \\
3
\end{array}\right) & \left(\begin{array}{l}
3 \\
2
\end{array}\right) & \left(\begin{array}{l}
3 \\
1
\end{array}\right) & \cdots & 0 & 0 \\
--- & --- & --- & --- & --- & --- \\
\left(\begin{array}{l}
p \\
p
\end{array}\right) & \left(\begin{array}{c}
p \\
p-1
\end{array}\right) & \left(\begin{array}{c}
p \\
p-2
\end{array}\right) & \cdots & \left(\begin{array}{c}
p \\
1
\end{array}\right) & 0 \\
\left(\begin{array}{l}
p+1 \\
p+1
\end{array}\right) & \left(\begin{array}{c}
p+1 \\
p
\end{array}\right) & \left(\begin{array}{c}
p+1 \\
p-1
\end{array}\right) & \cdots & \left(\begin{array}{c}
p+1 \\
2
\end{array}\right) & 0
\end{array}\right| .
$$

We have highlighted interconnections between the Stirling and Bernoulli numbers, and proved the connection between the sum of the $p$ th power of the first $n$ positive integers and Bernoulli numbers, which is the following:

$$
S_{p}=\frac{1}{p+1} \cdot \sum_{k=0}^{p}\left(\begin{array}{c}
p+1 \\
k
\end{array}\right) \cdot B_{k} \cdot(n+1)^{p+1-k} .
$$

The paper ends with a summary, and in the Appendix to the dissertation we show via several exercises the applicability of the formulas of sums of powers for different problem types. All of these problem types are presented in higher education, and the majority of them can be presented in secondary schools just as well. 


\section{Függelék: A témakörhöz kapcsolódó feladatok}

\section{Oszthatóság, számelmélet}

1. Bizonyítsuk be, hogy

$2 \cdot\left|\left[1^{2}-2^{2}+3^{2}-4^{2}+\ldots+(-1)^{n-1} \cdot n^{2}\right]+\left[1^{4}-2^{4}+3^{4}-4^{4}+\ldots+(-1)^{n-1} \cdot n^{4}\right]\right|$

egy teljes négyzet.

Megoldás

A 3.1.4. fejezetben levezettuik, hogy:

$$
\begin{aligned}
& 1^{2}-2^{2}+3^{2}-4^{2}+\ldots+(-1)^{n-1} \cdot n^{2}=(-1)^{n-1} \cdot \frac{n(n+1)}{2} . \\
& 1^{4}-2^{4}+3^{4}-4^{4}+\ldots+(-1)^{n-1} \cdot n^{4}=(-1)^{n-1} \cdot \frac{n(n+1)\left(n^{2}+n-1\right)}{2} .
\end{aligned}
$$

Ezek alapján:

$$
\begin{aligned}
& 2 \cdot\left|\left[1^{2}-2^{2}+3^{2}-4^{2}+\ldots+(-1)^{n-1} \cdot n^{2}\right]+\left[1^{4}-2^{4}+3^{4}-4^{4}+\ldots+(-1)^{n-1} \cdot n^{4}\right]\right|= \\
& \left.=2 \cdot \mid(-1)^{n-1} \cdot \frac{n(n+1)}{2}\right]+\left[(-1)^{n-1} \cdot \frac{n(n+1)\left(n^{2}+n-1\right)}{2}\right] \mid= \\
& =2 \cdot\left|(-1)^{n-1} \cdot \frac{n(n+1)}{2} \cdot\left(1+n^{2}+n-1\right)\right|=\left|(-1)^{n-1} \cdot n(n+1)\left(n^{2}+n\right)\right|=\left|(-1)^{n-1} \cdot n^{2}(n+1)^{2}\right|= \\
& =n^{2}(n+1)^{2}=\left(n^{2}+n\right)^{2} .
\end{aligned}
$$

Tehát:

$$
2 \cdot\left|\left[1^{2}-2^{2}+3^{2}-4^{2}+\ldots+(-1)^{n-1} \cdot n^{2}\right]+\left[1^{4}-2^{4}+3^{4}-4^{4}+\ldots+(-1)^{n-1} \cdot n^{4}\right]\right|=\left(n^{2}+n\right)^{2} \text {. }
$$

2. Legyen $n$ tetszőleges pozitív egész szám. Bizonyítsuk be, hogy a $3\left(1^{5}+2^{5}+3^{5}+\ldots+n^{5}\right)$ szám osztható az $\left(1^{3}+2^{3}+3^{3}+\ldots+n^{3}\right)$ számmal.

Megoldás

Felhasználva az $S_{5}$-re és $S_{3}$-ra bizonyított összefüggéseket:

$$
\begin{aligned}
& 3\left(1^{5}+2^{5}+3^{5}+\ldots+n^{5}\right)=3 \cdot S_{5}=3 \cdot \frac{n^{2}(n+1)^{2}\left(2 n^{2}+2 n-1\right)}{12}= \\
& =\frac{n^{2}(n+1)^{2}}{4} \cdot\left(2 n^{2}+2 n-1\right)=S_{3} \cdot\left(2 n^{2}+2 n-1\right)=\left(1^{3}+2^{3}+3^{3}+\ldots+n^{3}\right)\left(2 n^{2}+2 n-1\right) .
\end{aligned}
$$

Tehát:

$$
3\left(1^{5}+2^{5}+3^{5}+\ldots+n^{5}\right)=\left(1^{3}+2^{3}+3^{3}+\ldots+n^{3}\right)\left(2 n^{2}+2 n-1\right),
$$

amelyböl - felhasználva, hogy ha $n \in Z^{+}$, akkor $2 n^{2}+2 n-1$ szintén pozitív egész szám lesz - azonnal következik a bizonyítandó állítás. 
3. Bizonyítsuk be, hogy $n$ darab egymást követő pozitív egész szám köbének összege mindig osztható a számok összegével.

$\underline{\text { Megoldás }}$

Legyenek az adott számok: $a+1, a+2 \ldots, a+n$, ahol $a \in N$.

Felhasználva az $S_{1}$-re és $S_{3}$-ra bizonyított összefüggéseket, a felírt számok összege:

$$
\begin{aligned}
& X=(a+1)+(a+2)+\ldots+(a+n)=[1+2+\ldots+a+(a+1)+\ldots+(a+n)]-(1+2+\ldots+a)= \\
& =\frac{(a+n)(a+n+1)}{2}-\frac{a(a+1)}{2},
\end{aligned}
$$

míg a számok köbösszege:

$$
\begin{aligned}
& Y=(a+1)^{3}+(a+2)^{3}+\ldots+(a+n)^{3}= \\
& =\left[1^{3}+2^{3}+\ldots+a^{3}+(a+1)^{3}+\ldots+(a+n)^{3}\right]-\left(1^{3}+2^{3}+\ldots+a^{3}\right)= \\
& =\left[\frac{(a+n)(a+n+1)}{2}\right]^{2}-\left[\frac{a(a+1)}{2}\right]^{2} .
\end{aligned}
$$

Figyelembe véve az $A^{2}-B^{2}=(A+B) \cdot(A-B)$ azonosságot kapjuk, hogy:

$$
\begin{aligned}
& Y=\left[\frac{(a+n)(a+n+1)}{2}\right]^{2}-\left[\frac{a(a+1)}{2}\right]^{2}= \\
& =\left[\frac{(a+n)(a+n+1)}{2}+\frac{a(a+1)}{2}\right] \cdot\left[\frac{(a+n)(a+n+1)}{2}-\frac{a(a+1)}{2}\right]= \\
& =\left[\frac{(a+n)(a+n+1)}{2}+\frac{a(a+1)}{2}\right] \cdot X,
\end{aligned}
$$

ahonnan mivel mind az $(a+n)(a+n+1)$, mind pedig az $a(a+1)$ páros szám, azonnal következik, hogy $X \mid Y$.

4. Ha $A=1^{2}+2^{2}+3^{2}+\ldots+n^{2}$ nem osztható 5-tel, akkor mennyi a $B=1+2+3+\ldots+n$ szám 5-tel való osztási maradéka?

Megoldás

Felhasználva az $S_{2}$-re és $S_{1}$-re bizonyított összefüggéseket:

$$
\begin{aligned}
& A=1^{2}+2^{2}+3^{2}+\ldots+n^{2}=S_{2}=\frac{n(n+1)(2 n+1)}{6} . \\
& B=1+2+3+\ldots+n=S_{1}=\frac{n(n+1)}{2} .
\end{aligned}
$$

A feltétel szerint $A$ nem osztható 5 -tel, ez azt jelenti, hogy $n=5 k+1$ vagy $n=5 k+3$ alakú, ahol $k \in N$ (ha $n=5 k$ alakú, akkor az $n$, ha $n=5 k+2$ alakú, akkor a $2 n+1$, míg ha $n=5 k+4$ alakú, akkor az $n+1$ lesz osztható 5-tel).

$$
\begin{aligned}
& \text { Ha } n=5 k+1 \text {, akkor } B=\frac{(5 k+1)(5 k+2)}{2}=\frac{25 k^{2}+15 k+2}{2}=\frac{5\left(5 k^{2}+3 k\right)}{2}+1 . \\
& \text { Ha } n=5 k+3 \text {, akkor } B=\frac{(5 k+3)(5 k+4)}{2}=\frac{25 k^{2}+35 k+12}{2}=\frac{5\left(5 k^{2}+7 k+2\right)}{2}+1 .
\end{aligned}
$$

Tehát mindkét esetben azt kaptuk, hogy $B$-nek 5-tel való osztási maradéka 1. 
5. Mely pozitív egész $n$ számokra lesz az $1+2+\ldots+n$ összeg osztója az $1 \cdot 2+2 \cdot 3+\ldots+(n-1) n$ összegnek?

Megoldás

$\overline{\mathrm{Az}} 1 \cdot 2+2 \cdot 3+\ldots+(n-1) n$ összeghez még hozzáadjuk a $0 \cdot 1$-t (az összeg értéke nem változik). Ezáltal:

$0 \cdot 1+1 \cdot 2+2 \cdot 3+\ldots+(n-1) n=\sum_{k=1}^{n}(k-1) k=\sum_{k=1}^{n}\left(k^{2}-k\right)=\sum_{k=1}^{n} k^{2}-\sum_{k=1}^{n} k=S_{2}-S_{1}$.

Mivel $S_{2}=\frac{n(n+1)(2 n+1)}{6}$ és $S_{1}=\frac{n(n+1)}{2}$, így

$S_{2}-S_{1}=\frac{n(n+1)(2 n+1)}{6}-\frac{n(n+1)}{2}=\frac{n(n+1)}{2} \cdot\left(\frac{2 n+1}{3}-1\right)=S_{1} \cdot \frac{2 n-2}{3}=2 \cdot S_{1} \cdot \frac{n-1}{3}$,

vagyis

$1 \cdot 2+2 \cdot 3+\ldots+(n-1) n=2 \cdot S_{1} \cdot \frac{n-1}{3}$.

Tehát az $1 \cdot 2+2 \cdot 3+\ldots+(n-1) n$ összeg akkor és csak akkor osztható az $1+2+\ldots+n$ összeggel, ha $\frac{n-1}{3}$ nemnegatív egész szám, azaz $n=3 k+1$ alakú, ahol $k \in N$.

6. Adjuk meg azokat az egynél nagyobb $n$ természetes számokat, amelyekre az $1^{n}+2^{n}+3^{n}+\ldots+(n-1)^{n}+n^{n}$ szám osztható $n$-nel.

Megoldás

Elegendő csupán az $1^{n}+2^{n}+3^{n}+\ldots+(n-1)^{n}$ oszthatóságát vizsgálni, hiszen $n \mid n^{n}$.

a) Ha $n$ páratlan szám.

Ebben az esetben $\frac{n-1}{2}$ természetes szám. Legyen $k$ olyan természetes szám, ahol $1 \leq k \leq \frac{n-1}{2}$. Ekkor

$k^{n}+(n-k)^{n}=(k+n-k)\left[k^{n-1}+k^{n-2} \cdot(n-k)+\ldots+k \cdot(n-k)^{n-2}+(n-k)^{n-1}\right]=$ $=n\left[k^{n-1}+k^{n-2} \cdot(n-k)+\ldots+k \cdot(n-k)^{n-2}+(n-k)^{n-1}\right]$.

Így $n \mid\left[k^{n}+(n-k)^{n}\right]$.

Megfelelően csoportosítva az $1^{n}+2^{n}+3^{n}+\ldots+(n-1)^{n}=\sum_{k=1}^{\frac{n-1}{2}}\left[k^{n}+(n-k)^{n}\right]$ és mivel minden zárójelben lévő kifejezés osztható $n$-nel, így az összeg is osztható lesz $n$-nel.

Tehát $n \mid\left[1^{n}+2^{n}+3^{n}+\ldots+(n-1)^{n}\right]$.

b) Ha $n$ páros szám.

Legyen $t$ az a legnagyobb természetes szám, amelyre $2^{t} \mid n$.

Ha $k$ páros szám, akkor $2 \mid k$-ból következik, hogy $2^{n} \mid k^{n}$. Figyelembe véve, hogy $2^{t} \mid n$ és mivel $2^{t}>t$, következik, hogy $2^{t} \mid k^{n}$. 
Ha $k$ páratlan szám, akkor az Euler-Fermat tétel alapján $k^{2^{t-1}} \equiv 1\left(\bmod 2^{t}\right)$ és mivel $2^{t} \mid n$ következik, hogy $k^{n} \equiv 1\left(\bmod 2^{t}\right)$.

Így innen $1^{n}+3^{n}+\ldots+(n-3)^{n}+(n-1)^{n} \equiv \frac{n}{2} \cdot 1\left(\bmod 2^{t}\right)$.

Mivel $2^{n}+4^{n}+\ldots+(n-2)^{n} \equiv 0\left(\bmod 2^{t}\right)$, akkor a kapott eredmények alapján $1^{n}+2^{n}+\ldots+(n-2)^{n}+(n-1)^{n} \equiv \frac{n}{2}\left(\bmod 2^{t}\right)$.

Ha teljesülne az $n\left[1^{n}+2^{n}+3^{n}+\ldots+(n-1)^{n}\right], \quad$ akkor a $\quad 2^{t} \mid n \quad$ alapján $2^{t} \mid\left[1^{n}+2^{n}+3^{n}+\ldots+(n-1)^{n}\right]$ is fennállna, azaz $\frac{n}{2} \equiv 0\left(\bmod 2^{t}\right)$. Innen $2^{t} \mid \frac{n}{2}$, vagyis $2^{t+1} \mid n$, ami ellentmondás a $t$ értelmezésével.

Páros $n$ esetén tehát az $1^{n}+2^{n}+3^{n}+\ldots+(n-1)^{n}$ nem osztható $n$-nel.

Összegezve tehát a keresett számok az 1-nél nagyobb páratlan számok.

7. Legyen $A=\sum_{k=1}^{n} k$ és $B=\sum_{k=1}^{n} k^{3}$, ahol $n$ pozitív egész szám. Határozzuk meg a $B-A$ szám utolsó számjegyét.

$\underline{\text { Megoldás }}$

Felhasználva, hogy $\sum_{k=1}^{n} k=\frac{n(n+1)}{2}$ és $\sum_{k=1}^{n} k^{3}=\frac{n^{2}(n+1)^{2}}{4}$ kapjuk, hogy:

$B-A=\frac{n^{2}(n+1)^{2}}{4}-\frac{n(n+1)}{2}=\frac{n(n+1)}{4} \cdot\left(n^{2}+n-2\right)=\frac{n(n+1)}{4} \cdot(n-1)(n+2)$.

$B-A=\frac{(n-1) n(n+1)(n+2)}{4}$.

Jelöljük $S Z$-el a $B-A$ számlálóját. Az $S Z$ négy egymást követő egész szám szorzata, s így osztható 8-cal, tehát $B-A$ minden esetben páros szám lesz.

Ha $n=5 k$, akkor $S Z=(5 k-1) 5 k(5 k+1)(5 k+2)$, tehát $5 \mid S Z$.

Ha $n=5 k+1$, akkor $S Z=5 k(5 k+1)(5 k+2)(5 k+3)$, tehát $5 \mid S Z$.

Ha $n=5 k+3$, akkor $S Z=(5 k+2)(5 k+3)(5 k+4)(5 k+5)$, tehát $5 \mid S Z$.

Ha $n=5 k+4$, akkor $S Z=(5 k+3)(5 k+4)(5 k+5)(5 k+6)$, tehát $5 \mid S Z$.

Ezekben az esetekben a számláló még 5-tel is osztható, tehát a $B-A$ többszöröse lesz a 10-nek.

Ha $n=5 k+2$, akkor $S Z=(5 k+1)(5 k+2)(5 k+3)(5 k+4)$, vagyis a számláló $5 M_{1}+24$ alakú. Ugyanakkor a számláló $8 M_{2}$ alakú is, így az $M_{1}=8 M$ alakú is.

Mindezek alapján a számláló $5 M_{1}+24=40 M+24=4(10 M+6)$ alakú lesz, tehát a $B-A$ pedig $10 M+6$ alakú.

Összefoglalva, a $B-A$ utolsó számjegye 6 , ha $n=5 k+2$ alakú és 0 , ha $n=5 k$, $n=5 k+1, n=5 k+3$ vagy $n=5 k+4$ alakú. 
8. Bizonyítsuk be, hogy 35 egymást követő pozitív egész szám négyzetének összege mindig osztható 35-tel.

(KöMaL, B 4300, 2010/7)

$\underline{\text { Megoldás }}$

Legyenek az adott számok: $a, a+1, a+2, \ldots, a+34$ és legyen $s=a^{2}+(a+1)^{2}+(a+2)^{2}+\ldots+(a+34)^{2}$, ahol $a \in Z^{+}$.

A 3.3.4. fejezetben levezetett összefüggés alapján:

$$
a^{2}+(a+1)^{2}+\ldots+(a+n-1)^{2}=S_{2}(a, 1)=\frac{n}{6} \cdot\left[2 n^{2}+3 n(2 a-1)+6 a^{2}-6 a+1\right] .
$$

Mivel $n=35$, ezért

$$
\begin{aligned}
& s=\frac{35}{6} \cdot\left[2 \cdot 35^{2}+3 \cdot 35 \cdot(2 a-1)+6 a^{2}-6 a+1\right]=\frac{35}{6} \cdot\left(6 a^{2}+204 a+2346\right)= \\
& =35\left(a^{2}+34 a+391\right) .
\end{aligned}
$$

Innen figyelembe véve, hogy a pozitív egész következik, hogy $35 \mid s$.

\section{Megjegyzés}

Általánosan is vizsgáljuk meg a feladatot, azaz nézzük meg, hogy milyen $a$ és $n$ pozitív egészek esetén teljesül az, hogy $n$ darab egymást követő pozitív egész szám négyzetének összege mindig osztható $n$-nel.

Az $\quad a^{2}+(a+1)^{2}+\ldots+(a+n-1)^{2}=\frac{n}{6} \cdot\left[2 n^{2}+3 n(2 a-1)+6 a^{2}-6 a+1\right]$, azaz azt kell tanulmányoznunk, hogy a $2 n^{2}+3 n(2 a-1)+6 a^{2}-6 a+1$ kifejezés milyen $a$ és $n$ esetén lesz 6-nak többszöröse.

Mivel

$2 n^{2}+3 n(2 a-1)+6 a^{2}-6 a+1=6\left(a n+a^{2}-a\right)+2 n^{2}-3 n+1$,

elegendő azt vizsgálni, hogy a $2 n^{2}-3 n+1$ milyen $n$ esetén lesz osztható 6-tal.

Legyen $A=2 n^{2}-3 n+1=(2 n-1)(n-1)$.

Ha $n=6 k$, akkor $A=(12 k-1)(6 k-1)$, tehát $A$ nem osztható 6-tal.

Ha $n=6 k+1$, akkor $A=(12 k+1) \cdot 6 k$, tehát $6 \mid A$.

Ha $n=6 k+2$, akkor $A=(12 k+3)(6 k+1)$, tehát $A$ nem osztható 6-tal.

Ha $n=6 k+3$, akkor $A=(12 k+5)(6 k+2)$, tehát $A$ nem osztható 6-tal.

Ha $n=6 k+4$, akkor $A=(12 k+7)(6 k+3)$, tehát $A$ nem osztható 6-tal.

Ha $n=6 k+5$, akkor $A=(12 k+9)(6 k+4)=6(4 k+3)(3 k+2)$, tehát $6 \mid A$,

ahol mindegyik esetben $k \in N$.

Összefoglalva, tehát ha $n=6 k+1$ vagy $n=6 k+5$ alakú, ahol $k \in N$, akkor $a$-tól függetlenül $n$ darab egymást követő pozitív egész szám négyzetének összege mindig osztható $n$-nel.

9. Legyen a $p$ háromnál nagyobb prímszám. Bizonyítsuk be, hogy $p$ darab egymást követő pozitív egész szám négyzetének, illetve köbének összege mindig osztható $p$-vel. Igaz-e ez a tulajdonság a negyedik hatványok összege esetén is?

Megoldás

Legyenek az adott számok: $a, a+1, a+2, \ldots, a+p-1$, ahol $a \in Z^{+}$. 
i) négyzetösszeg esetén

Felhasználva az $(A+B)^{2}=A^{2}+2 A B+B^{2}$ azonosságot, mivel

$$
\begin{aligned}
& a^{2}+(a+1)^{2}+(a+2)^{2}+\ldots+(a+p-1)^{2}= \\
& =a^{2}+a^{2}+2 a+1+a^{2}+2 a \cdot 2+2^{2}+\ldots+a^{2}+2 a \cdot(p-1)+(p-1)^{2}= \\
& =p \cdot a^{2}+2 a \cdot(1+2+\ldots+p-1)+\left[1^{2}+2^{2}+\ldots+(p-1)^{2}\right]= \\
& =p \cdot a^{2}+2 a \cdot \frac{(p-1) p}{2}+\frac{(p-1) p(2 p-1)}{6}=p \cdot a^{2}+(p-1) p \cdot a+\frac{p(p-1)(2 p-1)}{6},
\end{aligned}
$$

elegendő azt belátni, hogy $\frac{p(p-1)(2 p-1)}{6}$ osztható $p$-vel. Ez azonban azonnal belátható figyelembe véve azt az ismert tényt, hogy a 3-nál nagyobb prímszámok mindegyike vagy $6 k+1$ (ekkor $p-1$ 6-nak többszöröse) vagy $6 k-1$ (ekkor $p-1$ páros szám és a $2 p-1$ pedig háromnak többszöröse) alakú, ahol $k \in Z^{+}$.

Tehát, ha a $p$ háromnál nagyobb prímszám, akkor $p$ darab egymást követő pozitív egész szám négyzetének összege mindig osztható $p$-vel.

(Az, hogy $p$ darab egymást követő pozitív egész szám négyzetének összege mindig osztható $p$-vel, ha $p>3$ prímszám, a 8.-as feladathoz tartozó megjegyzés alapján is azonnal belátható, hiszen a 3-nál nagyobb prímszámok mindegyike $6 k+1$ vagy $6 k-1$ alakú, ahol $k \in Z^{+}$).

ii) köbök összege esetén

Felhasználva az $(A+B)^{3}=A^{3}+3 A^{2} B+3 A B^{2}+B^{3}$ azonosságot, az előző pontban már megismert gondolatmenet alapján kapjuk, hogy

$$
\begin{aligned}
& a^{3}+(a+1)^{3}+(a+2)^{3}+\ldots+(a+p-1)^{3}= \\
& =p \cdot a^{3}+3 \cdot \frac{p(p-1)}{2} \cdot a^{2}+\frac{p(p-1)(2 p-1)}{2} \cdot a+\left[\frac{p(p-1)}{2}\right]^{2} .
\end{aligned}
$$

Figyelembe véve, hogy $p>3$ és prímszám, ezért a $p-1$ páros szám lesz, így az eredményként kapott összeg minden tagja osztható lesz $p$-vel.

Tehát, ha a $p$ háromnál nagyobb prímszám, akkor $p$ darab egymást követő pozitív egész szám köbének összege mindig osztható $p$-vel.

iii) negyedik hatványok összege esetén

Ebben az esetben a kért tulajdonság nem teljesül, hiszen ha például $a=1$ és $p=5$, akkor $1^{4}+2^{4}+3^{4}+4^{4}+5^{4}=979$, ami nem osztható 5-tel.

\section{Megjegyzés}

Bebizonyítható egy általánosabb állítás is, éspedig:

Ha p páratlan prímszám és $k$ egy olyan pozitív egész szám, amely nem többszöröse $(p-1)$ -nek, akkor p darab egymást követö pozitív egész szám k-adik hatványának összege mindig osztható p-vel.

Legyenek $a_{1}, a_{2}, \ldots, a_{p}$ az egymást követő pozitív egész számok és $r_{1}, r_{2}, \ldots, r_{p}$ ezen számoknak $p$-vel való osztásakor keletkező maradékok. Belátható, hogy $r_{1}, r_{2}, \ldots, r_{p}$ számok épp a $0,1,2, \ldots, p-1$ számok lesznek nem feltétlenül ebben a sorrendben.

Legyen $s=a_{1}^{k}+a_{2}^{k}+\ldots+a_{p-1}^{k}+a_{p}^{k}$ és 
$s_{k}=0^{k}+1^{k}+2^{k}+\ldots+(p-1)^{k}=1^{k}+2^{k}+\ldots+(p-1)^{k} . \quad$ Mivel $\quad a_{i} \equiv r_{i}(\bmod p)$, következik hogy $a_{i}^{k} \equiv r_{i}^{k}(\bmod p)$, minden $i \in\{1,2, \ldots, p\}$ esetén, tehát $s \equiv s_{k}(\bmod p)$.

Legyen $k=(p-1) \cdot q+r$, ahol az $0 \leq r<p-1$. A ,kis" Fermat-tétel értelmében $a^{p-1} \equiv 1(\bmod p)$, ha $a \in\{1,2, \ldots, p-1\}$, ahonnan $a^{k} \equiv a^{(p-1) \cdot q+r} \equiv a^{r}(\bmod p)$. Ez utóbbi összefüggésbe rendre behelyettesítve az $a$ helyére az $1,2, \ldots, p-1$ értékeket, majd ezeket összegezve kapjuk, hogy $s_{k} \equiv s_{r}(\bmod p)$. Figyelembe véve, hogy $s \equiv s_{k}(\bmod p)$, kapjuk hogy $s \equiv s_{r}(\bmod p)$.

Ha $r=0$, akkor $s_{0}=p-1$, tehát $s \equiv p-1(\bmod p)$.

A továbbiakban megmutatjuk, hogy az $r \neq 0$ esetén, vagyis ha $k \neq(p-1) \cdot q$, akkor az $s_{r} \equiv 0(\bmod p)$.

A bizonyítás a teljes indukció módszere segítségével történik.

Minden valós $h$ esetén:

$$
\begin{aligned}
& (h+1)^{r+1}=h^{r+1}+\left(\begin{array}{c}
r+1 \\
1
\end{array}\right) \cdot h^{r}+\left(\begin{array}{c}
r+1 \\
2
\end{array}\right) \cdot h^{r-1}+\left(\begin{array}{c}
r+1 \\
3
\end{array}\right) \cdot h^{r-2}+\ldots+\left(\begin{array}{c}
r+1 \\
r
\end{array}\right) \cdot h+\left(\begin{array}{c}
r+1 \\
r+1
\end{array}\right)= \\
& =h^{r+1}+(r+1) \cdot h^{r}+\frac{(r+1) r}{1 \cdot 2} \cdot h^{r-1}+\frac{(r+1) r(r-1)}{1 \cdot 2 \cdot 3} \cdot h^{r-2}+\ldots+(r+1) \cdot h+1,
\end{aligned}
$$

ahonnan

$$
(h+1)^{r+1}-h^{r+1}=(r+1) \cdot h^{r}+\frac{(r+1) r}{1 \cdot 2} \cdot h^{r-1}+\frac{(r+1) r(r-1)}{1 \cdot 2 \cdot 3} \cdot h^{r-2}+\ldots+(r+1) \cdot h+1 .
$$

A $h$ helyére rendre behelyettesítve az $1,2, \ldots, p-1$ értékeket, a kapott összefüggéseket összegezve, az összevonások és az átrendezés után kapjuk, hogy

$$
p^{r+1}=(r+1) \cdot s_{r}+\frac{(r+1) r}{1 \cdot 2} \cdot s_{r-1}+\frac{(r+1) r(r-1)}{1 \cdot 2 \cdot 3} \cdot s_{r-2}+\ldots+(r+1) \cdot s_{1}+p .
$$

Figyelembe véve, hogy $p$ prímszám és mivel $s_{1}=\frac{(p-1) p}{2}$, következik hogy $p \mid s_{1}$.

Tegyük fel, hogy $p \mid s_{l}$, minden $1 \leq l \leq r-1$ esetén. Azt kell belátnunk, hogy $p \mid s_{r}$.

Az indukciós feltételt és a $\left(^{*}\right)$ összefüggést felhasználva következik, hogy $p \mid(r+1) \cdot s_{r}$. Azonban az $r<p-1$, tehát $(p, r+1)=1$, ezért következik, hogy $p \mid s_{r}$ vagyis $s_{r} \equiv 0(\bmod p)$. Mivel $s \equiv s_{r}(\bmod p)$ és $s_{r} \equiv 0(\bmod p)$, innen $s \equiv 0(\bmod p)$ és ez az, amit bizonyítani akartunk.

\section{Egyenletek}

10. Oldjuk meg az $x^{3}+(x+1)^{3}+(x+2)^{3}=(x+3)^{3}$ egyenletet a valós számok halmazán.

Megoldás

A 3.3.4. fejezetben levezetett összefüggés alapján:

$$
S_{3}(x, 1)=\frac{n}{4} \cdot\left[n^{3}+2 n^{2}(2 x-1)+n\left(6 x^{2}-6 x+1\right)+4 x^{3}-6 x^{2}+2 x\right] \text {. }
$$


A mi esetünkben az $n=3$, tehát a megoldandó egyenlet átírható az

$$
(x+3)^{3}=\frac{3}{4} \cdot\left[27+18(2 x-1)+3\left(6 x^{2}-6 x+1\right)+4 x^{3}-6 x^{2}+2 x\right]
$$

alakra.

A müveletek elvégzése és az összevonások után:

$$
\begin{aligned}
& x^{3}+9 x^{2}+27 x+27=\frac{3}{4} \cdot\left(4 x^{3}+12 x^{2}+20 x+12\right)=3 x^{3}+9 x^{2}+15 x+9 . \\
& 2 x^{3}-12 x-18=0
\end{aligned}
$$

Ez utóbbi egyenletet végigosztva kettővel, majd megfelelően csoportosítva:

$$
\begin{aligned}
& x^{3}-6 x-9=x^{3}-3 x^{2}+3 x^{2}-9 x+3 x-9=0 . \\
& (x-3)\left(x^{2}+3 x+3\right)=0 .
\end{aligned}
$$

Figyelembe véve, hogy $0<x^{2}+3 x+3$ minden valós $x$-re, a kapott egyenletnek csak egy megoldása van a valós számok halmazán, éspedig az $x=3$.

11. Bizonyítsuk be, hogy minden $n$ pozitív egész számra az $x^{3}+(x+1)^{3}+\ldots+(x+n-1)^{3}=y^{3}$ egyenletnek $x$-re és $y$-ra van egész megoldása.

$\underline{\text { Megoldás }}$

Mivel $x^{3}+(x+1)^{3}+\ldots+(x+n-1)^{3}=S_{3}(x, 1)$, így a megoldandó egyenlet átírható az

$$
y^{3}=S_{3}(x, 1)=\frac{n}{4} \cdot\left[n^{3}+2 n^{2}(2 x-1)+n\left(6 x^{2}-6 x+1\right)+4 x^{3}-6 x^{2}+2 x\right]
$$

alakra.

Végigszorozva 4-gyel, majd az egyenlet jobb oldalát az $x$ hatványai szerint rendezve:

$4 y^{3}=n \cdot\left[4 x^{3}+6 x^{2}(n-1)+2 x\left(2 n^{2}-3 n+1\right)+n^{3}-2 n^{2}+n\right]$.

$4 y^{3}=n \cdot\left[4 x^{3}+6 x^{2}(n-1)+2 x(n-1)(2 n-1)+n(n-1)^{2}\right]$.

a) Ha $n$ páratlan szám, azaz $n=2 k+1$, ahol $k \in N$.

$$
\begin{aligned}
& 4 y^{3}=(2 k+1)\left[4 x^{3}+12 x^{2} k+4 x k(4 k+1)+4 k^{2}(2 k+1)\right] . \\
& 4 y^{3}=4(2 k+1)\left(x^{3}+3 x^{2} k+4 x k^{2}+x k+2 k^{3}+k^{2}\right) . \\
& y^{3}=(2 k+1)\left(x^{3}+3 x^{2} k+3 x k^{2}+x k^{2}+x k+k^{3}+k^{3}+k^{2}\right) .
\end{aligned}
$$

Átrendezve és megfelelően csoportosítva kapjuk hogy

$$
\begin{aligned}
& y^{3}=(2 k+1)\left[(x+k)^{3}+k^{2}(x+k)+k(x+k)\right] . \\
& y^{3}=(2 k+1)(x+k)\left[(x+k)^{2}+k^{2}+k\right] .
\end{aligned}
$$

E felírásból látható, hogy az $x=-k, y=0$ megoldása az egyenletnek.

b) Ha $n$ páros szám, azaz $n=2 k$, ahol $k \in N^{+}$.

$$
\begin{aligned}
& \left.4 y^{3}=2 k \mid 4 x^{3}+6 x^{2}(2 k-1)+2 x(2 k-1)(4 k-1)+2 k(2 k-1)^{2}\right] . \\
& 4 y^{3}=4 k\left(2 x^{3}+6 x^{2} k-3 x^{2}+8 x k^{2}-6 x k+x+4 k^{3}-4 k^{2}+k\right) .
\end{aligned}
$$

Végigosztva 4-gyel, átrendezve és megfelelően csoportosítva kapjuk hogy

$$
\begin{aligned}
& y^{3}=k\left(2 x^{3}+6 x^{2} k+6 x k^{2}+2 k^{3}-3 x^{2}-6 x k-3 k^{2}+2 x k^{2}+2 k^{3}+x+k-k^{2}\right) . \\
& y^{3}=k\left[2(x+k)^{3}-3(x+k)^{2}+2 k^{2}(x+k)+(x+k)-k^{2}\right] . \\
& y^{3}=k(x+k)\left[2(x+k)^{2}-3(x+k)+2 k^{2}+1\right]-k^{3} .
\end{aligned}
$$


E felírásból látható, hogy az $x=-k, y=-k$ megoldása az egyenletnek.

Összefoglalva, ha $n$ páratlan szám $(n=2 k+1, k \in N)$, akkor az $x=-k, y=0$, ha az $n$ páros szám $\left(n=2 k, k \in N^{+}\right)$, akkor pedig az $x=-k, y=-k$ biztosan megoldása az egyenletnek.

12. Oldjuk meg $1^{2}+2^{2}+3^{2}+\ldots+x^{2}=x^{p+1}$ egyenletet a pozitív egész számok halmazán, ahol $p \geq 2$ természetes szám.

Megoldás

Felhasználva, hogy $1^{2}+2^{2}+3^{2}+\ldots+x^{2}=\frac{x(x+1)(2 x+1)}{6}$, ahol $x$ pozitív egész szám, a megoldandó egyenlet a következő lesz:

$\frac{x(x+1)(2 x+1)}{6}=x^{p+1}$.

Mivel $x>0$ az adott egyenlet megszorozható $\frac{6}{x}$-el, így:

$2 x^{2}+3 x+1=6 x^{p}$.

$6 x^{p}-2 x^{2}-3 x-1=0$.

Észrevehető, hogy az adott egyenletnek az $x=1$ megoldása. Akár polinomosztással, akár a Horner-féle elrendezés segítségével felírható, hogy

$6 x^{p}-2 x^{2}-3 x-1=(x-1)\left(6 x^{p-1}+6 x^{p-2}+\ldots+6 x^{2}+4 x+1\right)$.

Figyelembe véve, hogy $0<6 x^{p-1}+6 x^{p-2}+\ldots+6 x^{2}+4 x+1$ minden $x$ pozitív egész esetén, az adott egyenletnek csak egyetlen megoldása van a $Z^{+}$-n, éspedig az $x=1$.

13. Bizonyítsuk be, hogy 55 darab egymást követő egész szám négyzetének összege nem lehet négyzetszám.

(OKTV II. kategória, II. forduló, 2009-2010)

$\underline{\text { Megoldás }}$

Jelölje az ötvenöt szám közül a középsőt az $x$.

Azt kell belátnunk, hogy az $(x-27)^{2}+(x-26)^{2}+\ldots+(x+27)^{2}=y^{2}$ egyenletnek nincs megoldása egész számok halmazán.

A 3.3.4. fejezetben levezetett összefüggés alapján:

$$
a^{2}+(a+1)^{2}+\ldots+(a+n-1)^{2}=S_{2}(a, 1)=\frac{n}{6} \cdot\left[2 n^{2}+3 n(2 a-1)+6 a^{2}-6 a+1\right] .
$$

A felírt összefüggést felhasználva, ha $a=x-27$ és $n=55$, a megoldandó egyenlet átírható az alábbi alakra:

$$
\begin{aligned}
& y^{2}=\frac{55}{6} \cdot\left[2 \cdot 55^{2}+165 \cdot(2 x-54-1)+6 \cdot(x-27)^{2}-6 \cdot(x-27)+1\right] . \\
& y^{2}=\frac{55}{6} \cdot\left(6050+330 x-9075+6 x^{2}-324 x+4374-6 x+162+1\right) . \\
& y^{2}=\frac{55}{6} \cdot\left(6 x^{2}+1512\right)=55\left(x^{2}+252\right) .
\end{aligned}
$$

Az 55 $\left(x^{2}+252\right)$-nek egy egész szám négyzetének kell lennie. Ez csak úgy lehetséges, ha $x^{2}+252=55 k^{2}$, azaz $x^{2}=55 k^{2}-252$, ahol $k$ egész szám. 
Figyelembe véve, hogy az 5 egész többszörösei 0-ban vagy 5-ben végződnek, így az $x^{2}$ utolsó számjegye 8 vagy 3 lenne. Ez azonban nem lehetséges, mert egy egész szám négyzetének utolsó számjegye csak $0,1,4,5,6$ vagy 9 lehet.

Tehát az $(x-27)^{2}+(x-26)^{2}+\ldots+(x+27)^{2}=y^{2} \quad$ egyenletnek nincsenek egész megoldásai, vagyis 55 darab egymást követő egész szám négyzetének összege nem lehet négyzetszám.

14. Adjuk meg azt a legkisebb tizenegy egymást követő pozitív egész számot, amelynek a négyzetösszege egy pozitív egész szám négyzete!

(Egyetemi felvételi feladat, 1992)

$\underline{\text { Megoldás }}$

Jelölje a tizenegy szám közül a középsőt az $x$. Megoldandó az $(x-5)^{2}+(x-4)^{2}+\ldots+(x+5)^{2}=y^{2}$ egyenlet, ahol $x$ és $y$ pozitív egész számok, illetve az $x>5$.

A 3.3.4. fejezetben levezetett összefüggés alapján:

$$
a^{2}+(a+1)^{2}+\ldots+(a+n-1)^{2}=S_{2}(a, 1)=\frac{n}{6} \cdot\left[2 n^{2}+3 n(2 a-1)+6 a^{2}-6 a+1\right] .
$$

A felírt összefüggést felhasználva, ha $a=x-5$ és $n=11$, a megoldandó egyenlet átírható az alábbi alakra:

$$
\begin{aligned}
& y^{2}=\frac{11}{6} \cdot\left[2 \cdot 11^{2}+33 \cdot(2 x-10-1)+6 \cdot(x-5)^{2}-6 \cdot(x-5)+1\right] . \\
& y^{2}=\frac{11}{6} \cdot\left(242+66 x-363+6 x^{2}-60 x+150-6 x+30+1\right) . \\
& y^{2}=\frac{11}{6} \cdot\left(6 x^{2}+60\right)=11\left(x^{2}+10\right) .
\end{aligned}
$$

A $11\left(x^{2}+10\right)$-nek egy pozitív szám négyzetének kell lennie. Ez csak úgy lehetséges, ha $x^{2}+10=11 k^{2}$, ahol $k$ egész szám (elegendő azzal az esettel foglalkoznunk, mikor $k$ pozitív egész).

Készítsünk táblázatot $k$ egymást követő értékeire, a kezdeti feltételek figyelembevételével:

\begin{tabular}{|l|c|c|c|c|c|c|c|}
\hline$k$ & 1 & 2 & 3 & 4 & 5 & 6 & 7 \\
\hline$x^{2}=11 k^{2}-10$ & 1 & 34 & 89 & 166 & 265 & 386 & 529 \\
\hline$x$ & 1 & \multicolumn{6}{|c|}{ nem egész szám } \\
\hline
\end{tabular}

Az $x=1$ nem felel meg, hiszen nem teljesíti az $x>5$ feltételt (a tizenegy szám között lenne negatív is).

Az $x=23$ esetén a tizenegy szám a $18 ; 19 ; 20 ; 21 ; 22 ; 23 ; 24 ; 25 ; 26 ; 27 ; 28$; ezek négyzetösszege 5929, és ez valóban négyzetszám, mégpedig $77^{2}$, azaz $y=77$.

\section{Megjegyzés}

Tanulmányozva $x$ lehetséges értékeit, egyszerü számításokkal meggyőződhetünk róla, hogy az $x$-nek $11 m \pm 1$ alakúnak kell lennie, ahol $m \in N^{+}$. Ha nincs elöírva, hogy a legkisebb ilyen $x$-re van szükségünk, akkor a feladatnak léteznek más megoldásai is, például az $\left\{\begin{array}{l}x=43 \\ y=143\end{array}\right.$ vagy $\left\{\begin{array}{l}x=461 \\ y=1529\end{array}\right.$ stb. 
15. Keressük meg azt a legkisebb $n \geq 2$ természetes számot, amelynek köbe felírható $n$ darab egymást követő természetes szám négyzetének összegével.

$\underline{\text { Megoldás }}$

Megoldandó az $a^{2}+(a+1)^{2}+\ldots+(a+n-1)^{2}=n^{3}$ egyenlet, ahol $a$ és $n$ természetes számok, úgy hogy $n \geq 2$.

Mivel $a^{2}+(a+1)^{2}+\ldots+(a+n-1)^{2}=S_{2}(a, 1)$, így a 3.3.4. fejezetben levezetett összefüggés alapján a megoldandó egyenlet átírható az

$$
\frac{n}{6} \cdot\left[2 n^{2}+3 n(2 a-1)+6 a^{2}-6 a+1\right]=n^{3}
$$

alakra.

Tudva, hogy az $n \geq 2$, az egyenletet végigszorozzuk $\frac{6}{n}$-nel, majd $a$ hatványai szerint rendezzük:

$$
\begin{aligned}
& 2 n^{2}+6 n a-3 n+6 a^{2}-6 a+1=6 n^{2} . \\
& 6 a^{2}+6 a(n-1)-4 n^{2}-3 n+1=0 .
\end{aligned}
$$

Felírva az $a$-ban másodfokú egyenlet diszkriminánsát:

$$
\begin{aligned}
& D=36(n-1)^{2}-24\left(-4 n^{2}-3 n+1\right)=36 n^{2}-72 n+36+96 n^{2}+72 n-24=132 n^{2}+12 . \\
& D=4\left(33 n^{2}+3\right)
\end{aligned}
$$

A kapott $33 n^{2}+3$ egy teljes négyzet kell legyen, azaz olyan $t$ egész számot kell keresnünk, amelyre fennáll a $t^{2}=33 n^{2}+3$ egyenlőség.

Egyfelöl $t^{2}=33 n^{2}+3=3\left(11 n^{2}+1\right)$, ezért a $t$ osztható kell legyen 3 -mal, tehát $t=3 l$ alakú, ahol $l$ egész szám.

Másrészt pedig $t^{2}-3=11 \cdot 3 n^{2}$, ezért a $11\left(t^{2}-3\right)$. Figyelembe véve $t$ lehetséges felírásait (a 11-gyel való osztás maradékai szerint), majd mindet kipróbálva azt kapjuk, hogy $t$ vagy $11 k+5$ vagy $11 k+6$ alakú lehet, vagyis $t=11 k \mp 5$ alakú, ahol $k$ egész szám.

Összefoglalva a kapott eredményeket:

$$
\left.\begin{array}{l}
\begin{array}{l}
t=3 l \\
t=11 k \mp 5 \\
k, l \in Z
\end{array}
\end{array}\right\} \Rightarrow t=33 m \pm 6 \text { alakú, ahol } m \in Z .
$$

Így $33 n^{2}+3=t^{2}=(33 m \pm 6)^{2}=33^{2} \cdot m^{2} \pm 33 \cdot 12 m+36$,

ahonnan $n^{2}=33 m^{2} \pm 12 m+1$.

Az $m$ helyére rendre pozitív egész számokat helyettesítve (a negatív egészeket behelyettesítve ugyanazokat az értékeket kapnánk) és az eredményeket egy táblázatba foglalva a következőket kapjuk: 


\begin{tabular}{|c|c|c|c|c|}
\hline$m$ & $n^{2}=33 m^{2}+12 m+1$ & $n$ & $n^{2}=33 m^{2}-12 m+1$ & $n$ \\
\hline 1 & 46 & $\notin N$ & 22 & $\notin N$ \\
\hline 2 & 157 & $\notin N$ & 109 & $\notin N$ \\
\hline 3 & 334 & $\notin N$ & 262 & $\notin N$ \\
\hline 4 & 577 & $\notin N$ & 481 & $\notin N$ \\
\hline 5 & 886 & $\notin N$ & 766 & $\notin N$ \\
\hline 6 & 1261 & $\notin N$ & 1117 & $\notin N$ \\
\hline 7 & 1702 & $\notin N$ & 1534 & $\notin N$ \\
\hline 8 & 2209 & 47 & 2017 & $\notin N$ \\
\hline 9 & 2782 & $\notin N$ & 2566 & $\notin N$ \\
\hline
\end{tabular}

Tehát a legkisebb $n$ természetes szám, amelynek köbe felírható $n$ darab egymást követő természetes szám négyzetének összegével a 47 lesz. Ebben az esetben (és erről egyszerü számításokkal meggyőződhetünk) az $a=22$, azaz

$$
22^{2}+23^{2}+\ldots+68^{2}=103823=47^{3} \text {. }
$$

\section{Megjegyzés}

Ha nincs elöírva, hogy a legkisebb ilyen $n$-re van szükségünk, akkor a feladatnak létezik más megoldása is, például az $n=2161(a=989)$.

16. Oldjuk meg a prímszámok halmazán a következő egyenletet:

$[\sqrt[3]{1}]+[\sqrt[3]{2}]+[\sqrt[3]{3}]+\ldots+\left[\sqrt[3]{x^{3}-1}\right]=y$

ahol $[a]$-val az $a$ valós szám egész részét jelöltük.

Megoldás

Belátható, hogy $\left[\sqrt[3]{n^{3}+k}\right\rfloor=n$, bármely $n \in Z^{+}$és bármely $k \in\{0,1, \ldots, 3 n(n+1)\}$ esetén.

Ekkor $\sum_{k=0}^{3 n(n+1)}\left[\sqrt[3]{n^{3}+k}\right]=n \cdot 3 n(n+1)+n=3 n^{3}+3 n^{2}+n$, bármely $n \in Z^{+}$-re.

Tehát:

$$
\begin{aligned}
& {[\sqrt[3]{1}]+[\sqrt[3]{2}]+[\sqrt[3]{3}]+\ldots+\left[\sqrt[3]{x^{3}-1}\right]=\left([\sqrt[3]{1}]+[\sqrt[3]{2}]+\ldots+\left[\sqrt[3]{(1+1)^{3}-1}\right]\right)+} \\
& +\left([\sqrt[3]{8}]+[\sqrt[3]{9}]+\ldots+\left[\sqrt[3]{(2+1)^{3}-1}\right]\right)+\ldots+\left(\left[\sqrt[3]{(x-1)^{3}}\right]+\left[\sqrt[3]{(x-1)^{3}+1}\right]+\ldots+\left[\sqrt[3]{x^{3}-1}\right]\right)= \\
& =\sum_{k=1}^{x-1}\left(3 k^{3}+3 k^{2}+k\right)=3 \cdot \sum_{k=1}^{x-1} k^{3}+3 \cdot \sum_{k=1}^{x-1} k^{2}+\sum_{k=1}^{x-1} k= \\
& =3 \cdot \frac{(x-1)^{2} x^{2}}{4}+3 \cdot \frac{(x-1) x(2 x-1)}{6}+\frac{(x-1) x}{2}=\frac{(x-1) x}{4} \cdot\left(3 x^{2}-3 x+4 x-2+2\right)= \\
& =\frac{(x-1) x}{4} \cdot\left(3 x^{2}+x\right)=\frac{x^{2}(x-1)(3 x+1)}{4}
\end{aligned}
$$

A megoldandó egyenlet tehát az $\frac{x^{2}(x-1)(3 x+1)}{4}=y$, ahol az $x, y \in Z^{+}$prímszámok.

Ha $x=2$, akkor $y=\frac{4 \cdot 1 \cdot 7}{4}=7$, tehát megoldás. 
Ha $x \neq 2$, akkor $x$ páratlan szám, azaz egy $2 m+1\left(m \in Z^{+}\right)$alakú prímszám. Ekkor az $y=\frac{(2 m+1)^{2} 2 m(6 m+4)}{4}=m(2 m+1)^{2}(3 m+2)$, amely egy összetett természetes szám lesz. Következésképpen ebben az esetben az adott egyenletnek nincs megoldása a prímszámok halmazán.

Összefoglalva, az egyenlet egyedüli megoldása: $x=2, y=7$.

\section{Megjegyzés}

A feladatból nyert $[\sqrt[3]{1}]+[\sqrt[3]{2}]+[\sqrt[3]{3}]+\ldots+\left[\sqrt[3]{x^{3}-1}\right]=\frac{x^{2}(x-1)(3 x+1)}{4}$ összefüggésröl, illetve általánosan az $[\sqrt[k]{1}]^{p}+[\sqrt[k]{2}]^{p}+\ldots+[\sqrt[k]{n}]^{p}$ alakú összegekröl többet megtudhatunk a [17]-ből.

\section{Összegek, előállítások}

17. Számítsuk ki az alábbi összegeket:
a) $1 \cdot 2+2 \cdot 5+3 \cdot 8+\ldots+n(3 n-1)$.
b) $1 \cdot \frac{3}{2} \cdot 2+2 \cdot \frac{5}{2} \cdot 3+3 \cdot \frac{7}{2} \cdot 4+\ldots+n\left(n+\frac{1}{2}\right)(n+1)$.
c) $\sum_{i=1}^{n} \sum_{j=1}^{i} \sum_{l=1}^{j} l$.
d) $1^{3} \cdot n+2^{3} \cdot(n-1)+3^{3} \cdot(n-2)+\ldots+n^{3} \cdot 1$.
e) $1 \cdot 2+(1+2) \cdot 3+(1+2+3) \cdot 4+\ldots+(1+2+3+\ldots+n) \cdot(n+1)$.

\section{Megoldás}

a)

$$
\begin{aligned}
& 1 \cdot 2+2 \cdot 5+3 \cdot 8+\ldots+n(3 n-1)=\sum_{k=1}^{n} k(3 k-1)=\sum_{k=1}^{n}\left(3 k^{2}-k\right)=3 \cdot \sum_{k=1}^{n} k^{2}-\sum_{k=1}^{n} k=3 \cdot S_{2}-S_{1}= \\
& =3 \cdot \frac{n(n+1)(2 n+1)}{6}-\frac{n(n+1)}{2}=\frac{n(n+1)}{2} \cdot(2 n+1-1)=\frac{n(n+1)}{2} \cdot(2 n)=n^{2}(n+1) .
\end{aligned}
$$

b)

$$
\begin{aligned}
& 1 \cdot \frac{3}{2} \cdot 2+2 \cdot \frac{5}{2} \cdot 3+3 \cdot \frac{7}{2} \cdot 4+\ldots+n\left(n+\frac{1}{2}\right)(n+1)=\sum_{k=1}^{n} k\left(k+\frac{1}{2}\right)(k+1)=\frac{1}{2} \cdot \sum_{k=1}^{n} k(k+1)(2 k+1)= \\
& =\frac{1}{2} \cdot \sum_{k=1}^{n}\left(2 k^{3}+3 k^{2}+k\right)=\sum_{k=1}^{n} k^{3}+\frac{3}{2} \cdot \sum_{k=1}^{n} k^{2}+\frac{1}{2} \cdot \sum_{k=1}^{n} k=S_{3}+\frac{3}{2} \cdot S_{2}+\frac{1}{2} \cdot S_{1}= \\
& =\frac{n^{2}(n+1)^{2}}{4}+\frac{3}{2} \cdot \frac{n(n+1)(2 n+1)}{6}+\frac{1}{2} \cdot \frac{n(n+1)}{2}=\frac{n(n+1)}{4} \cdot\left(n^{2}+n+2 n+1+1\right)= \\
& =\frac{n(n+1)}{4} \cdot\left(n^{2}+3 n+2\right)=\frac{n(n+1)}{4} \cdot(n+1)(n+2)=\frac{n(n+1)^{2}(n+2)}{4} .
\end{aligned}
$$


c)

$$
\begin{aligned}
& \sum_{i=1}^{n} \sum_{j=1}^{i} \sum_{l=1}^{j} l=\sum_{i=1}^{n} \sum_{j=1}^{i} \frac{j(j+1)}{2}=\frac{1}{2} \cdot \sum_{i=1}^{n} \sum_{j=1}^{i}\left(j^{2}+j\right)=\frac{1}{2} \cdot \sum_{i=1}^{n}\left(\sum_{j=1}^{i} j^{2}+\sum_{j=1}^{i} j\right)= \\
& =\frac{1}{2} \cdot \sum_{i=1}^{n}\left[\frac{i(i+1)(2 i+1)}{6}+\frac{i(i+1)}{2}\right]=\frac{1}{2} \cdot \frac{1}{6} \cdot \sum_{i=1}^{n} i(i+1)(2 i+1+3)=\frac{1}{6} \cdot \sum_{i=1}^{n} i(i+1)(i+2) .
\end{aligned}
$$

Felhasználva a 3.4.1. fejezet (3.4.4) összefüggését a $k=2$ esetben:

$\sum_{i=1}^{n} \sum_{j=1}^{i} \sum_{l=1}^{j} l=\frac{1}{6} \cdot \sum_{i=1}^{n} i(i+1)(i+2)=\frac{1}{6} \cdot \frac{n(n+1)(n+2)(n+3)}{2+2}=\frac{n(n+1)(n+2)(n+3)}{24}$.

d)

$$
\begin{aligned}
& 1^{3} \cdot n+2^{3} \cdot(n-1)+3^{3} \cdot(n-2)+\ldots+n^{3} \cdot 1=\sum_{k=1}^{n}\left[k^{3} \cdot(n+1-k)\right]=\sum_{k=1}^{n}\left[(n+1) \cdot k^{3}-k^{4}\right]= \\
& =(n+1) \cdot \sum_{k=1}^{n} k^{3}-\sum_{k=1}^{n} k^{4}=(n+1) \cdot S_{3}-S_{4}= \\
& =(n+1) \cdot \frac{n^{2}(n+1)^{2}}{4}-\frac{n(n+1)(2 n+1)\left(3 n^{2}+3 n-1\right)}{30}= \\
& =\frac{n(n+1)}{60} \cdot\left(15 n^{3}+30 n^{2}+15 n-12 n^{3}-12 n^{2}+4 n-6 n^{2}-6 n+2\right)= \\
& =\frac{n(n+1)}{60} \cdot\left(3 n^{3}+12 n^{2}+13 n+2\right)=\frac{n(n+1)}{60} \cdot\left(3 n^{3}+6 n^{2}+6 n^{2}+12 n+n+2\right)= \\
& =\frac{n(n+1)}{60}(n+2)\left(3 n^{2}+6 n+1\right)=\frac{n(n+1)(n+2)\left(3 n^{2}+6 n+1\right)}{60} .
\end{aligned}
$$

e)

$$
\begin{aligned}
& 1 \cdot 2+(1+2) \cdot 3+(1+2+3) \cdot 4+\ldots+(1+2+3+\ldots+n) \cdot(n+1)=\sum_{i=1}^{n}[(1+2+\ldots+i) \cdot(i+1)]= \\
& =\sum_{i=1}^{n}\left[\frac{i(i+1)}{2} \cdot(i+1)\right]=\frac{1}{2} \cdot \sum_{i=1}^{n}\left(i^{3}+2 i^{2}+i\right)=\frac{1}{2} \cdot\left(\sum_{i=1}^{n} i^{3}+2 \cdot \sum_{i=1}^{n} i^{2}+\sum_{i=1}^{n} i\right)= \\
& =\frac{1}{2} \cdot\left(S_{3}+2 \cdot S_{2}+S_{1}\right)=\frac{1}{2} \cdot\left[\frac{n^{2}(n+1)^{2}}{4}+2 \cdot \frac{n(n+1)(2 n+1)}{6}+\frac{n(n+1)}{2}\right]= \\
& =\frac{1}{2} \cdot \frac{n(n+1)}{12} \cdot\left(3 n^{2}+3 n+8 n+4+6\right)=\frac{n(n+1)}{24} \cdot\left(3 n^{2}+11 n+10\right)= \\
& =\frac{n(n+1)(n+2)(3 n+5)}{24} .
\end{aligned}
$$


Megjegyzés:

A feladat a) pontjának szemléletes bizonyítása (F.1. ábra):

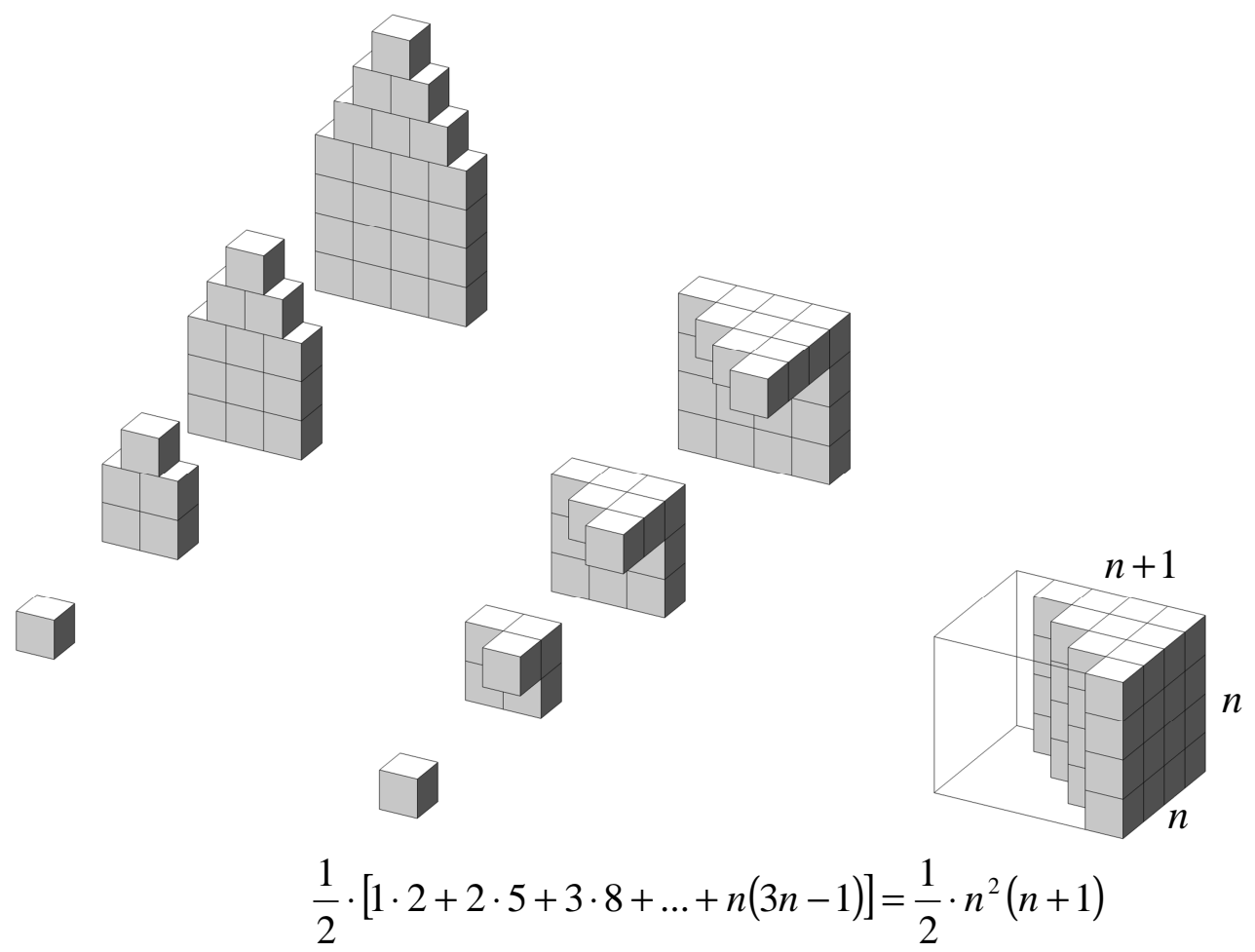

F.1. ábra

18. Bizonyítsuk be, hogy egymást követő pozitív egész számok összege nem lehet 2-nek pozitív egész kitevős hatványa.

$\underline{\text { Megoldás }}$

Legyenek az egymást követő pozitív egész számok: $a ; a+1 ; a+2 ; \ldots ; a+(n-1)$, ahol $a, n \in Z^{+} ; n \geq 2$. Az adott számok összege a számtani sorozat összegképlete alapján $s=\frac{n}{2} \cdot(n+2 a-1)$. Azt kell belátnunk, hogy $s$ nem lehet $2^{k}$ alakú, ahol $k$ pozitív egész szám.

Ha $s=2^{k}$ lenne, akkor $2 s=n(n+2 a-1)$ a 2-nek szintén pozitív egész kitevős hatványa lenne. Mivel a kezdeti feltételek miatt $n \geq 2$ és $n+2 a-1>1$, az $n(n+2 a-1)$ szorzat csak akkor lehetne 2-nek valamilyen pozitív egész kitevős hatványa, ha mindkét tényezője ilyen tulajdonságú, tehát páros szám lenne.

De a két tényező különbsége $(n+2 a-1)-n=2 a-1$ páratlan szám, vagyis mindkét tényező nem lehet egyszerre páros szám. Ezért $s$ nem lehet $2^{k}$ alakú és ezt kellett bizonyítanunk.

19. Legyen $k$ egy tetszőleges pozitív egész szám. Bizonyítsuk be, hogy a $3^{2 k}$ előáll $3^{k}$ számú egymást követő természetes szám összegeként.

\section{Megoldás}

Ha $3^{2 k}=a+(a+1)+\ldots+\left(a+3^{k}-1\right)$, akkor egy olyan számtani sorozat első $3^{k}$ tagjának összegéről van szó, mely sorozat első tagja $a$, differenciája pedig $1(a \in N)$. 
A 3.3.4. fejezetben levezetett összefüggés alapján $S_{1}(a, 1)=\frac{n}{2} \cdot(n+2 a-1)$. Mivel ebben az esetben az $n=3^{k}$, így

$$
\begin{aligned}
& 3^{2 k}=\frac{3^{k}}{2} \cdot\left(3^{k}+2 a-1\right) \cdot \frac{2}{3^{k}} . \\
& 2 \cdot 3^{k}=3^{k}+2 a-1,
\end{aligned}
$$

ahonnan $a=\frac{3^{k}+1}{2}$, ami természetes szám.

Tehát a $3^{2 k}$ valóban előáll $3^{k}$ számú egymást követő természetes szám összegeként, amelyek közül a legkisebb $\frac{3^{k}+1}{2}$.

Például: ha $k=1$, akkor $3^{2}=2+3+4$.

ha $k=2$, akkor $3^{4}=5+6+7+\ldots+13$.

Megjegyzés

A feladat általánosítható olyan formában, hogy a 3 helyett tetszőleges, egynél nagyobb $n$ páratlan szám állhat, azaz hogy az $n^{2 k}$ előállítható $n^{k}$ számú egymást követő természetes szám összegeként, amelyek közül a legkisebb $\frac{n^{k}+1}{2}$.

Például: ha $n=5$ és $k=1$, akkor $5^{2}=3+4+5+6+7$.

ha $n=7$ és $k=2$, akkor $7^{4}=25+26+27+\ldots+73$.

20. Legyen $n$ egy tetszőleges pozitív egész szám. Bizonyítsuk be, hogy az $n^{3}$ előáll $n$ darab egymást követő pozitív páratlan egész szám összegeként!

\section{Megoldás}

A 4.1.4. fejezetben levezetett összefüggés alapján $S_{1}(a, d)=\frac{n}{2} \cdot(n d+2 a-d)$.

Mivel páratlan számok összegéről van szó, így $d=2$, azaz $S_{1}(a, 2)=\frac{n}{2} \cdot(2 n+2 a-2)=n(n+a-1)$, ahol $a$ egy páratlan szám.

Így $n(n+a-1)=n^{3}$, amit végigosztva $n$-nel, majd átrendezve kapjuk, hogy $a=n^{2}-n+1=n(n-1)+1$.

Figyelembe véve, hogy $n(n-1)$ minden pozitív egész $n$ esetén páros szám és nemnegatív is, ezáltal az $a=n(n-1)+1$ pozitív is és páratlan szám is, azaz teljesíti a feladat feltételeit.

Tehát a keresett $n$ darab szám, amelyre $n^{3}$ elöáll $n$ darab egymást követő pozitív páratlan egész szám összegeként:

$n^{2}-n+1 ; n^{2}-n+3 ; \ldots ; n^{2}+n-3 ; n^{2}+n-1$,

azaz

$n(n-1)+1 ; n(n-1)+3 ; \ldots ; n(n+1)-3 ; n(n+1)-1$. 
Megjegyzés

A feladat szemléletes bizonyítása (F.2. ábra):
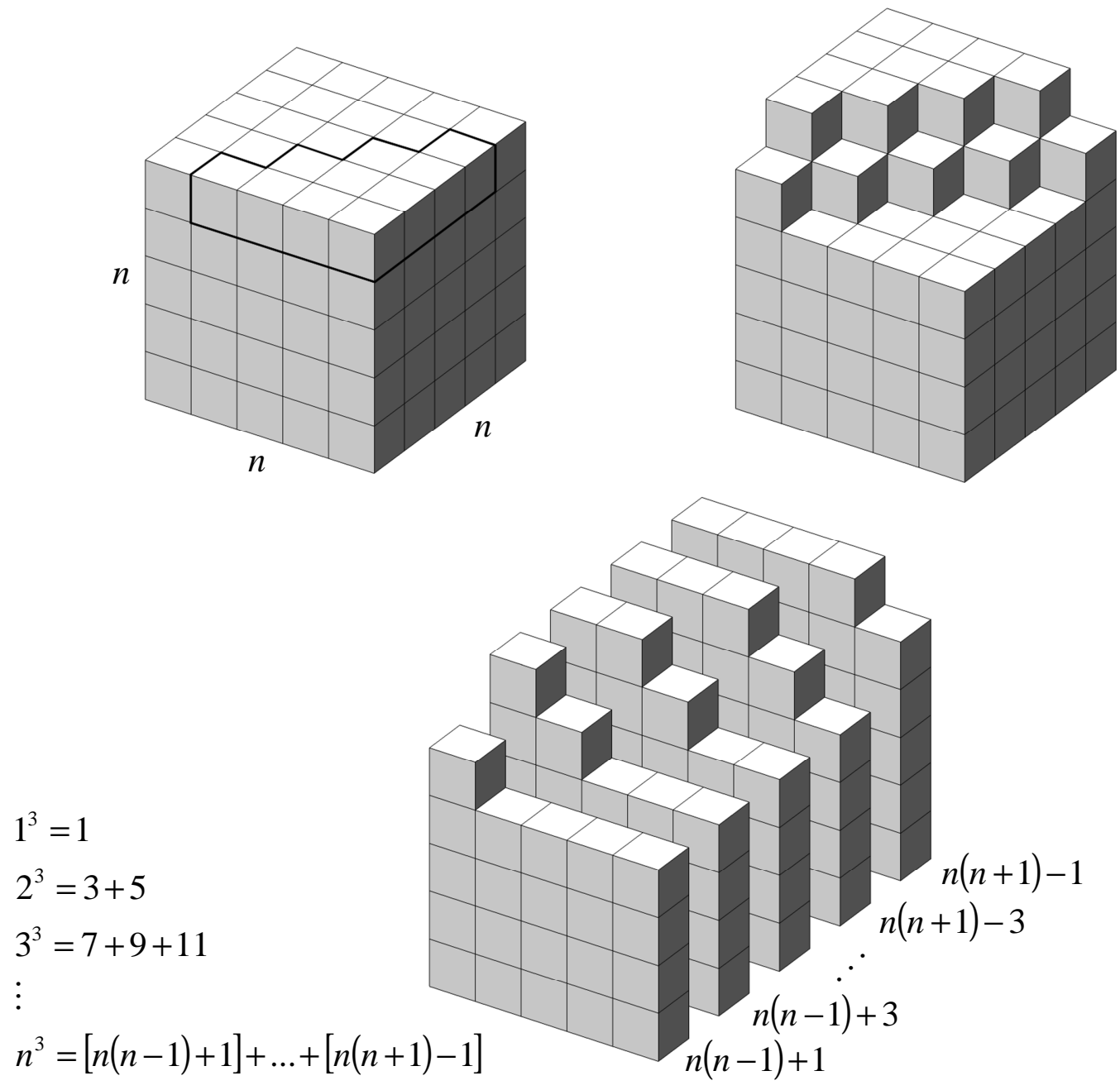

F.2. ábra

21. Adjuk meg azt a legkisebb $n>1$ természetes számot, amelyre az 1-től $n$-ig terjedő számok négyzeteinek összege valamely természetes szám négyzete.

$\underline{\text { Megoldás }}$

Ismeretes, hogy $1^{2}+2^{2}+3^{2}+\ldots+n^{2}=\frac{n(n+1)(2 n+1)}{6}$. Azt az $n>1$ legkisebb természetes számot kell megkeresnünk, amelyre $n(n+1)(2 n+1)=6 m^{2}$, ahol $m$ természetes szám. Az n-nek 6-tal való osztási maradékai szerint hat esetet különböztetünk meg:

1) $n=6 k$, ahol $k$ természetes szám.

Egyenletünk ekkor $k(6 k+1)(12 k+1)=m^{2}$ alakú lesz. A baloldalon szereplő tényezők páronként relatív prímek, tehát az egyenlőség érdekében mindegyiknek négyzetszámnak kell lennie.

$$
\begin{aligned}
& k=1 \Rightarrow 6 k+1=7 \quad \text { nem négyzetszám } \\
& k=4 \Rightarrow 6 k+1=25 \text { és } 12 k+1=49 \text { is négyzetszám }
\end{aligned}
$$

Tehát $n=6 \cdot 4=24$ teljesíti a feltételt és $1^{2}+2^{2}+3^{2}+\ldots+24^{2}=4900=70^{2}$. 
2) $n=6 k+1$.

Egyenletünk ekkor $(6 k+1)(3 k+1)(4 k+1)=m^{2}$ alakú lesz. A baloldalon szereplő $6 k+1, \quad 3 k+1, \quad 4 k+1$ számok közül (amelyek páronként relatív prímek), mindegyiknek négyzetszámnak kell lennie. A $k$ nem lehet nulla, hiszen így nem teljesülne az $n>1$ feltétel.

$$
\begin{array}{llll}
k=1 \quad \Rightarrow & 6 k+1=7 & \text { nem négyzetszám } \\
k=2 \Rightarrow & 6 k+1=13 & \text { nem négyzetszám } \\
k=3 \quad \Rightarrow & 6 k+1=19 & \text { nem négyzetszám } \\
k=4 \quad \Rightarrow \quad 6 k+1=25 & \text { négyzetszám }
\end{array}
$$

A legkisebb $k$ természetes szám, amelyre a $6 k+1$ négyzetszám a $k=4$, de ekkor már az $n=6 k+1=25>24$.

3) $n=6 k+2$.

Egyenletünk ekkor $(3 k+1)(2 k+1)(12 k+5)=m^{2}$ alakú lesz. Ekkor a $3 k+1,2 k+1$, $12 k+5$ számok mindegyikének (mint páronként relatív prímeknek), négyzetszámoknak kell lenniük.

$$
\begin{array}{lll}
k=0 \quad \Rightarrow & 12 k+5=5 & \text { nem négyzetszám. } \\
k=1 \quad \Rightarrow & 2 k+1=3 & \text { nem négyzetszám } \\
k=2 \Rightarrow & 2 k+1=5 & \text { nem négyzetszám } \\
k=3 \quad \Rightarrow & 2 k+1=7 & \text { nem négyzetszám } \\
k=4 \Rightarrow & 2 k+1=9 & \text { négyzetszám }
\end{array}
$$

A legkisebb $k$ természetes szám, amelyre $2 k+1$ négyzetszám a $k=4$, de ekkor már az $n=6 k+2=26>24$.

4) $n=6 k+3$.

Egyenletünk ekkor $(2 k+1)(3 k+2)(12 k+7)=m^{2}$ alakú lesz. Amellett, hogy a $2 k+1$, $3 k+2$ és $12 k+7$ számok páronként relatív prímek, még négyzetszámoknak is kell lenniük. Ha $k=0$, akkor $12 k+7$ nem négyzetszám. Felhasználva az előző aleset eredményeit, a legkisebb 0 -tól különböző $k$, amelyre a $2 k+1$ négyzetszám szintén a 4 lesz, de ekkor már $n=6 k+3=27>24$.

5) $n=6 k+4$.

Egyenletünk ekkor $(3 k+2)(6 k+5)(4 k+3)=m^{2}$ alakú lesz, ahol mivel a $3 k+2$, $6 k+5$ és $4 k+3$ számok páronként relatív prímek, ezért négyzetszámoknak kell lenniük.

$$
\begin{array}{llll}
k=0 \quad & \Rightarrow & 6 k+5=5 & \text { nem négyzetszám } \\
k=1 \quad \Rightarrow & 6 k+5=11 & \text { nem négyzetszám } \\
k=2 \quad \Rightarrow \quad 6 k+5=17 & \text { nem négyzetszám } \\
k=3 \quad \Rightarrow \quad 6 k+5=23 & \text { nem négyzetszám }
\end{array}
$$

Tehát $k \geq 4$-nek kell lennie, de így már $n=6 k+4=28>24$.

6) $n=6 k+5$.

Egyenletünk ekkor $(6 k+5)(k+1)(12 k+11)=m^{2}$ alakú lesz, ahol a $6 k+5, k+1$ és $12 k+11$ számok páronként relatív prímek, tehát négyzetszámoknak is kell lenniük. Felhasználva az előző aleset eredményeit, itt is $k \geq 4$-nek kell lennie, de így már $n=6 k+5=29>24$.

Összegezve bebizonyítottuk, hogy a legkisebb $n>1$ természetes szám, amelyre az $1^{2}+2^{2}+3^{2}+\ldots+n^{2}$ összeg négyzetszám, az $n=24$. 


\section{Megjegyzés}

G.N. Watson 1918-ban bebizonyította, hogy az $1^{2}+2^{2}+3^{2}+\ldots+n^{2}=m^{2}$ egyenletnek csak két megoldása van a pozitív egész számok halmazán, éspedig: $\left\{\begin{array}{l}n=1 \\ m=1\end{array}\right.$ és $\left\{\begin{array}{l}n=24 \\ m=70\end{array}\right.$.

22. Bizonyítsuk be, hogy minden 6-tól különböző páros tökéletes szám felírható egymást követő páratlan számok köbének az összegeként.

Megoldás

Felhasználva a 4.1.4. fejezetben levezetett $1^{3}+3^{3}+5^{3}+\ldots+(2 n-1)^{3}=n^{2}\left(2 n^{2}-1\right)$ összefüggést, azt kell belátnunk, hogy minden 6-nál nagyobb páros tökéletes szám felírható megfelelően megválasztott $n$ természetes számra $n^{2}\left(2 n^{2}-1\right)$ alakban.

Felhasználjuk azt az ismert tényt, hogy egy $A$ páros szám akkor és csak akkor tökéletes szám, ha $A=2^{p-1} \cdot\left(2^{p}-1\right)$ alakú, ahol mind a $p$, mind pedig a $2^{p}-1$ prímszám (bizonyítását lásd [2], 234-235. o.).

Mindezek alapján:

$$
\begin{aligned}
& A=2^{p-1} \cdot\left(2^{p}-1\right)=2^{p-1} \cdot\left(2 \cdot 2^{p-1}-1\right)=2^{2 \cdot \frac{p-1}{2}} \cdot\left(2 \cdot 2^{2 \cdot \frac{p-1}{2}}-1\right)= \\
& =\left(2^{\frac{p-1}{2}}\right)^{2} \cdot\left[2 \cdot\left(2^{\frac{p-1}{2}}\right)^{2}-1\right]=n^{2}\left(2 n^{2}-1\right),
\end{aligned}
$$

ahol az $n=2^{\frac{p-1}{2}}$.

Példák:

$$
\begin{array}{lll}
A=28 & p=3 & n=2 . \\
A=496 & p=5 & n=4 . \\
A=8128 & p=7 & n=8 . \\
A=33550336 & p=13 & n=64 .
\end{array}
$$

23. Létezik-e $2 n+1$ ( $n$ pozitív egész) egymást követő természetes szám úgy, hogy az

a) első $n+1$ szám összege egyenlő az utolsó $n$ szám összegével?

b) első $n+1$ szám négyzeteinek összege egyenlő az utolsó $n$ szám négyzeteinek összegével?

c) első $n+1$ szám köbeinek összege egyenlő az utolsó $n$ szám köbeinek összegével?

Megoldás

Legyen a $2 n+1$ egymást követő természetes szám:

$x ; x+1 ; x+2 ; \ldots ; x+n ; x+n+1 ; \ldots ; x+2 n-1 ; x+2 n$, ahol $x \in N$.

a)

Teljesülnie kell az alábbi összefüggésnek:

$x+(x+1)+(x+2)+\ldots+(x+n)=(x+n+1)+\ldots+(x+2 n-1)+(x+2 n)$.

Átrendezve:

$x+n=(x+2 n)-x+(x+2 n-1)-(x+1)+\ldots+(x+n+1)-(x+n-1)$.

$x+n=2 n+(2 n-2)+\ldots+2$. 
$x+n=2 \cdot(n+n-1+\ldots+2+1)=2 \cdot \frac{n(n+1)}{2}=n^{2}+n$.

Innen $x=n^{2}$.

Tehát a keresett $2 n+1$ szám, bármely $n \in Z^{+}$esetén: $n^{2} ; n^{2}+1 ; n^{2}+2 ; \ldots ; n^{2}+2 n$.

b)

Teljesülnie kell az alábbi összefüggésnek:

$x^{2}+(x+1)^{2}+(x+2)^{2}+\ldots+(x+n)^{2}=(x+n+1)^{2}+\ldots+(x+2 n-1)^{2}+(x+2 n)^{2}$.

Átrendezve, majd alkalmazva az $A^{2}-B^{2}=(A+B)(A-B)$ azonosságot kapjuk, hogy

$$
\begin{aligned}
& (x+n)^{2}=(x+2 n)^{2}-x^{2}+(x+2 n-1)^{2}-(x+1)^{2}+\ldots+(x+n+1)^{2}-(x+n-1)^{2} . \\
& (x+n)^{2}=(2 x+2 n) \cdot 2 n+(2 x+2 n) \cdot(2 n-2)+\ldots+(2 x+2 n) \cdot 2 . \\
& (x+n)^{2}=2 \cdot(2 x+2 n)(n+n-1+\ldots+2+1)=2 \cdot(2 x+2 n) \cdot \frac{n(n+1)}{2}=2(x+n)\left(n^{2}+n\right) .
\end{aligned}
$$

Mivel $x+n>0$, ezért végigoszthatunk vele, így $x+n=2 n^{2}+2 n$, ahonnan $x=2 n^{2}+n$.

Tehát a keresett $2 n+1$ szám, bármely $n \in Z^{+}$esetén:

$2 n^{2}+n ; 2 n^{2}+n+1 ; 2 n^{2}+n+2 ; \ldots ; 2 n^{2}+3 n$.

c)

Teljesülnie kell az alábbi összefüggésnek:

$x^{3}+(x+1)^{3}+(x+2)^{3}+\ldots+(x+n)^{3}=(x+n+1)^{3}+\ldots+(x+2 n-1)^{3}+(x+2 n)^{3}$.

Átrendezve:

$(x+n)^{3}=(x+2 n)^{3}-x^{3}+(x+2 n-1)^{3}-(x+1)^{3}+\ldots+(x+n+1)^{3}-(x+n-1)^{3}=$

$=\sum_{i=1}^{n}\left[(x+n+i)^{3}-(x+n-i)^{3}\right]$.

Alkalmazva az $(A+B)^{3}-(A-B)^{3}=6 A^{2} B+2 B^{3}$ azonosságot kapjuk, hogy

$(x+n)^{3}=\sum_{i=1}^{n}\left[(x+n+i)^{3}-(x+n-i)^{3}\right]=\sum_{i=1}^{n}\left[6 \cdot(x+n)^{2} \cdot i+2 \cdot i^{3}\right]=$

$=6(x+n)^{2} \cdot \sum_{i=1}^{n} i+2 \cdot \sum_{i=1}^{n} i^{3}=6(x+n)^{2} \cdot \frac{n(n+1)}{2}+2 \cdot \frac{n^{2}(n+1)^{2}}{4}$.

Innen $2(x+n)^{3}=6(x+n)^{2} \cdot n(n+1)+n^{2}(n+1)^{2}$.

Legyen $y=n(n+1)$. Így a következő ( $y$-ban másodfokú) egyenlethez jutunk:

$y^{2}-6(x+n)^{2} \cdot y-2(x+n)^{3}=0$

A $\left(^{*}\right)$ egyenletnek csak akkor van egész megoldása, ha diszkriminánsa négyzetszám. Az egyenlet diszkriminánsa $D=36(x+n)^{4}+8(x+n)^{3}=4(x+n)^{2} \cdot\left[9(x+n)^{2}+2(x+n)\right]$. A diszkrimináns csak akkor lesz négyzetszám, ha $9(x+n)^{2}+2(x+n)$ is az. Tehát léteznie kell egy $z$ természetes számnak úgy, hogy a

$9(x+n)^{2}+2(x+n)-z^{2}=0$

egyenlet (amely $(x+n)$-ben másodfokú) rendelkezzen egy pozitív egész megoldással.

Ehhez a $(* *)$ egyenlet diszkriminánsának négyzetszámnak kell lennie. Az egyenlethez tartozó diszkrimináns $\Delta=4+36 z^{2}=4\left(1+9 z^{2}\right)$, ahonnan következik, hogy az $1+9 z^{2}$ 
négyzetszám kell legyen. Ez viszont nem teljesülhet, ugyanis figyelembe véve, hogy $z$ természetes szám $(3 z)^{2}=9 z^{2}<1+9 z^{2}<1+6 z+9 z^{2}=(1+3 z)^{2}$.

Tehát nem létezik $2 n+1$ egymást követő természetes szám úgy, hogy első $n+1$ szám köbeinek összege egyenlő az utolsó $n$ szám köbeinek összegével.

\section{Megjegyzés}

A feladat a) pontjának szemléletes bizonyítása (F.3. ábra):

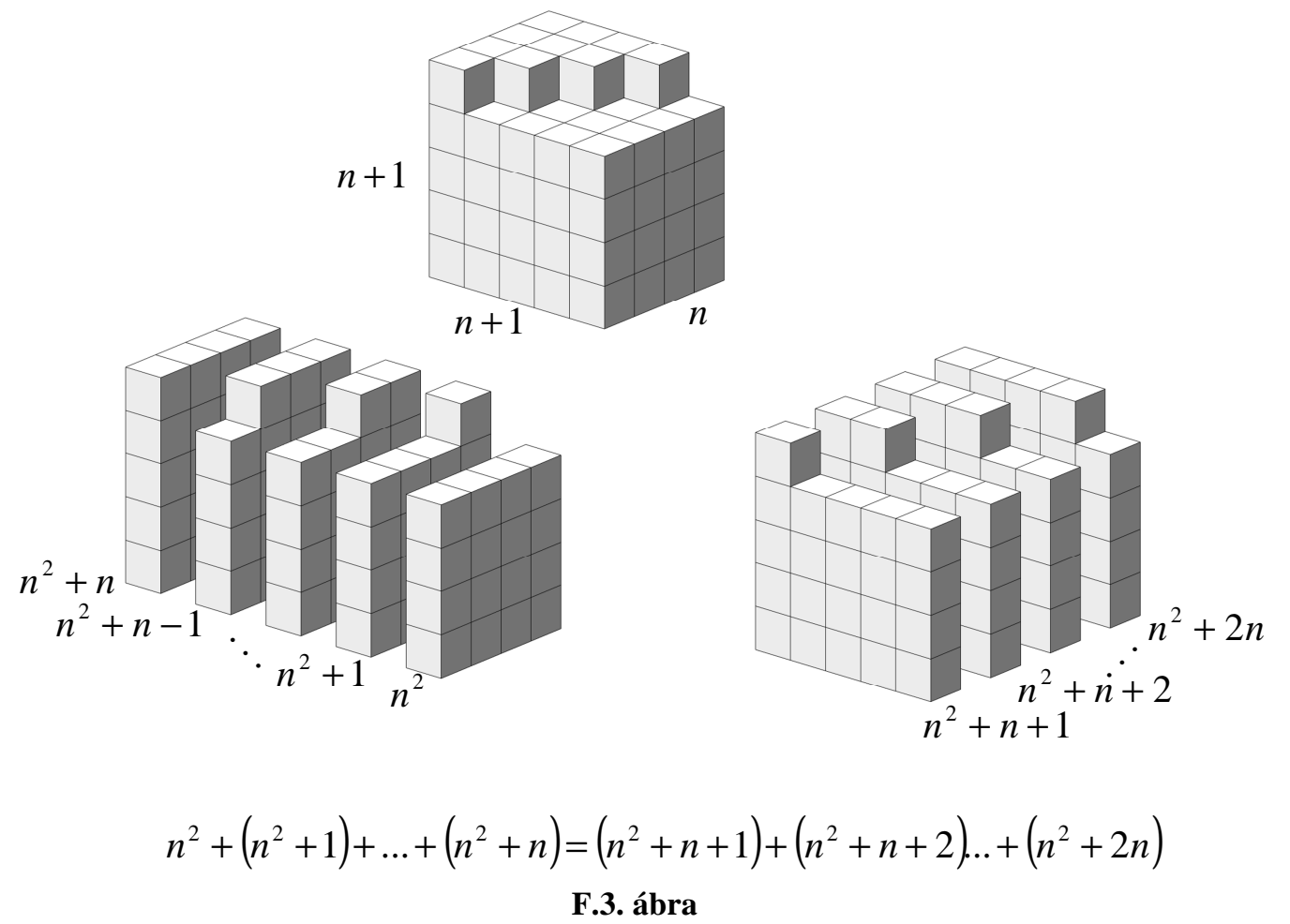

24. Legyen $p \geq 3$ egy prímszám. Jelöljük $a_{k}$-val a $k^{p}$ számnak $p^{2}$-tel való osztási maradékát minden $k$-ra 1-től $(p-1)$-ig.

Bizonyítsuk be, hogy $a_{1}+a_{2}+\ldots+a_{p-1}=\frac{p^{3}-p^{2}}{2}$.

$\underline{\text { Megoldás }}$

A kezdeti feltételek alapján a $p-1$ egy páros szám lesz. Mivel az $a_{1}+a_{2}+\ldots+a_{p-1}$ összegben $p-1$ tag van, ezért csoportosíthatjuk kettesével a tagokat, éspedig $\left(a_{1}+a_{p-1}\right)+\left(a_{2}+a_{p-2}\right)+\ldots$ módon, azaz összesen $\frac{p-1}{2}$ darab $a_{k}+a_{p-k}$ csoportunk lesz.

Bebizonyítanunk, hogy $a_{k}+a_{p-k}=p^{2}$, minden $k \in\left\{1,2, \ldots, \frac{p-1}{2}\right\}$ esetén, ezáltal $\frac{p-1}{2}$ darab $p^{2}$-es tagunk lesz és ezek összege pontosan $\frac{p^{3}-p^{2}}{2}$-vel egyenlő.

A feladat feltételei alapján: $k^{p}=\mathrm{M} p^{2}+a_{k}$, illetve $(p-k)^{p}=\mathrm{M}^{2}+a_{p-k}$, ahol az $\mathrm{M} p^{2}$ a $p^{2}$ többszörösét jelöli. 
A binomiális tétel alapján $(p-k)^{p}=\mathrm{M} p^{2}+\left(\begin{array}{c}p \\ p-1\end{array}\right) \cdot p-k^{p}=\mathrm{M} p^{2}+p^{2}-k^{p} \quad$ (a kapott egyenlöségben a $p^{2}$-et azért nem csatoltuk az $\mathrm{M} p^{2}$-hez, mert a maradék nem lehet negatív, vagyis csak a $-k^{p}$ nem lehet a $p^{2}$-tel való osztás maradéka).

Mivel az $a_{p-k}>0$, ezért az $a_{p-k}$-t a $p^{2}-k^{p}$-böl kapjuk $p^{2}$-tel történő osztással, vagyis $p^{2}-k^{p}=p^{2}-\left(\mathrm{M} p^{2}+a_{k}\right)=\mathrm{M} p^{2}+p^{2}-a_{k} \Rightarrow a_{p-k}=p^{2}-a_{k}$, ahonnan azonnal belátható a bizonyítandó $a_{k}+a_{p-k}=p^{2}$ összefüggés.

\section{Megjegyzés}

Ha $q_{k}$-val jelöljük a $k^{p}$ számnak $p^{2}$-tel való osztási hányadosát, akkor

$1^{p}=q_{1} \cdot p^{2}+a_{1}$

$2^{p}=q_{2} \cdot p^{2}+a_{2}$

$---------$

A felírt egyenlőségeket összegezve:

$(p-1)^{p}=q_{p-1} \cdot p^{2}+a_{p-1}$

$1^{p}+2^{p}+\ldots+(p-1)^{p}=p^{2} \cdot\left(q_{1}+q_{2}+\ldots+q_{p-1}\right)+\left(a_{1}+a_{2}+\ldots+a_{p-1}\right)$.

Mivel $a_{1}+a_{2}+\ldots+a_{p-1}=\frac{p^{3}-p^{2}}{2}$, a kapott összefüggés átírható az alábbi alakra is:

$q_{1}+q_{2}+\ldots+q_{p-1}=\frac{1^{p}+2^{p}+\ldots+(p-1)^{p}}{p^{2}}-\frac{p-1}{2}$.

\section{Sorozatok}

25. Igazoljuk, hogy a háromszögszámok sorozatában az utolsó számjegyek ismétlődnek!

Megoldás

Legyen $\left\{s_{n}\right\}_{n \geq 1}$ a háromszögszámok sorozata.

A sorozat $n$-edik tagja: $s_{n}=1+2+3+\ldots+n=\frac{n(n+1)}{2}$.

A sorozat $(n+20)$-dik tagja: $s_{n+20}=1+2+3+\ldots+(n+20)=\frac{(n+20)(n+21)}{2}$.

$\mathrm{Az}\left\{s_{n}\right\}$ sorozat $(n+20)$-dik tagjának és az $n$-edik tagjának különbsége:

$s_{n+20}-s_{n}=\frac{(n+20)(n+21)}{2}-\frac{n(n+1)}{2}=\frac{n^{2}+41 n+420-n^{2}-n}{2}=\frac{40 n+420}{2}=10(2 n+21)$.

Tehát az $s_{n+20}-s_{n}$ különbség osztható 10-zel. Ez azt jelenti, hogy a sorozat tagjainak utolsó számjegyeiből álló sorozat 20-asával ismétlődik. 
26. Tekintsünk $n$ darab olyan számtani sorozatot, amelyeknek első tagja megegyezik és az állandó különbség rendre $1 ; 2 ; \ldots ; n$. Igazoljuk, hogy ezen sorozatok első $n$ tagjának összegei egy számtani sorozat egymást követő tagjai.

Megoldás

Legyen az adott számtani sorozatok első tagja $a$.

A 4.1.4. fejezetben levezetett összefüggés alapján $S_{1}(a, d)=\frac{n}{2} \cdot(n d+2 a-d)$. Jelölje $\omega_{k}$ azon számtani sorozat első $n$ tagjának az összegét, melynek állandó különbsége $k$, vagyis $\omega_{k}=\frac{n}{2} \cdot(n k+2 a-k)$, ahol $k=1 ; 2 ; \ldots ; n$. Ekkor:

$\omega_{k+1}-\omega_{k}=\frac{n}{2} \cdot[n(k+1)+2 a-(k+1)]-\frac{n}{2} \cdot(n k+2 a-k)=$

$=\frac{n}{2} \cdot(n k+n+2 a-k-1-n k-2 a+k)=\frac{n}{2} \cdot(n-1)=\frac{n^{2}-n}{2}$,

azaz az $\omega_{k+1}-\omega_{k}$ különbség értéke független $k$-tól (mindig állandó), tehát az $\omega_{1}, \omega_{2}, \ldots$, $\omega_{n}$ egy számtani sorozat egymást követő tagjai.

Az így kapott $\left\{\omega_{n}\right\}_{n \geq 1}$ sorozat első $n$ tagjának összege:

$\sum_{k=1}^{n} \omega_{k}=\frac{n}{2} \cdot\left(\omega_{1}+\omega_{n}\right)=\frac{n}{2} \cdot\left[\frac{n}{2} \cdot(n+2 a-1)+\frac{n}{2} \cdot\left(n^{2}+2 a-n\right)\right]=\frac{n^{2}}{4} \cdot\left(n^{2}+4 a-1\right)$.

27. Legyen adott egy $\left\{a_{n}\right\}_{n \geq 0}$ sorozat úgy, hogy $a_{0}=a_{1}=0$ és $a_{n+1}-2 a_{n}+a_{n-1}=n$, minden $n \in N^{+}$esetén. Számítsuk ki az alábbi határértéket: $\lim _{n \rightarrow \infty} \sqrt[n]{\frac{a_{n}}{n(n-1)}}$.

(III. Hegyi Lajos Emlékverseny, 1999)

Megoldás

Az $a_{n+1}-2 a_{n}+a_{n-1}=n$ rekurziós összefüggésben az $n$ helyébe rendre helyettesítsük be az $1,2, \ldots, n-1$ értékeket, majd az így kapott összefüggéseket adjuk össze. Az összevonások után kapjuk, hogy:

$a_{n}-a_{n-1}-a_{1}+a_{0}=1+2+\ldots+(n-1)$.

Figyelembe véve, hogy $a_{0}=a_{1}=0$ és $1+2+\ldots+(n-1)=\frac{(n-1) n}{2}$ kapjuk, hogy:

$a_{n}-a_{n-1}=\frac{n(n-1)}{2}$.

Ha az így kapott rekurziós összefüggésben az $n$ helyébe újból rendre behelyettesítjük ezúttal az 1,2, ,.,n értékeket és az így kapott összefüggéseket ismét összeadjuk, akkor az összevonások után:

$a_{n}-a_{1}=\sum_{k=1}^{n} \frac{k(k-1)}{2}=\frac{1}{2} \cdot \sum_{k=1}^{n} k(k-1)$.

Mivel $a_{1}=0$ és felhasználva a 3.4.1. fejezet (3.4.4) összefüggését, mely alapján $\sum_{k=1}^{n}(k-1) k=\frac{(n-1) n(n+1)}{3}$, azt kapjuk, hogy az $a_{n}=\frac{1}{2} \cdot \frac{(n-1) n(n+1)}{3}=\frac{(n-1) n(n+1)}{6}$ lesz. 
Tehát:

$$
\lim _{n \rightarrow \infty} \sqrt[n]{\frac{a_{n}}{n(n-1)}}=\lim _{n \rightarrow \infty} \sqrt[n]{\frac{\frac{(n-1) n(n+1)}{6}}{n(n-1)}}=\lim _{n \rightarrow \infty} \sqrt[n]{\frac{n+1}{6}}=1 .
$$

28. Határozzuk meg azokat az $a_{1}, a_{2}, \ldots, a_{n}$ pozitív egész számokat, amelyek bármely $n \in N^{+}$ esetén teljesítik a következő összefüggést:

$a_{1}^{3}+a_{2}^{3}+\ldots+a_{n}^{3}=\left(a_{1}+a_{2}+\ldots+a_{n}\right)^{2}$.

Megoldás

A számok megkeresése a teljes indukció módszerének segítségével történik.

Az összefüggés az alábbi ismert összefüggésekre emlékeztet:

$1+2+3+\ldots+n=\frac{n(n+1)}{2}$.

$1^{3}+2^{3}+3^{3}+\ldots+n^{3}=\frac{n^{2}(n+1)^{2}}{4}$.

$1^{3}+2^{3}+3^{3}+\ldots+n^{3}=(1+2+3+\ldots+n)^{2}$.

Az igazolandó összefüggésnek minden $n \in N^{+}$esetén teljesülnie kell, ezért legyen $n=1$. Ebben az esetben $a_{1}^{3}=a_{1}^{2}$ egyenlőséghez jutunk, de mivel az $a_{1}$ pozitív szám következik, hogy az $a_{1}=1$ lesz.

Legyen $n=2$. Ekkor $1+a_{2}^{3}=\left(1+a_{2}\right)^{2}$. Átrendezés és a müveletek elvégzése után az $a_{2}^{3}-a_{2}^{2}-2 a_{2}=0$ egyenlethez jutunk, amelynek megoldásai $a_{2}=0, a_{2}=-1$ és $a_{2}=2$.

Az első kettő az $a_{2}$ pozitív volta miatt nem lehetséges, tehát az $a_{2}=2$ lesz.

Tételezzük fel, hogy $a_{n}=n$ és bizonyítsuk be, hogy $a_{n+1}=n+1$.

A feltételben adott összefüggést felírva $n \rightarrow n+1$-re és felhasználva az indukciós feltételt $\left(a_{1}=1, a_{2}=2, \ldots, a_{n}=n\right)$ :

$1^{3}+2^{3}+3^{3}+\ldots+n^{3}+a_{n+1}^{3}=\left(1+2+3+\ldots+n+a_{n+1}\right)^{2}$.

$1^{3}+2^{3}+3^{3}+\ldots+n^{3}+a_{n+1}^{3}=(1+2+3+\ldots+n)^{2}+2(1+2+\ldots+n) \cdot a_{n+1}+a_{n+1}^{2}$,

ahonnan:

$a_{n+1}^{3}=2 \cdot \frac{n(n+1)}{2} \cdot a_{n+1}+a_{n+1}^{2}$.

$a_{n+1}^{3}-a_{n+1}^{2}-n(n+1) \cdot a_{n+1}=0$.

A kapott egyenlet megoldásai: $a_{n+1}=0, a_{n+1}=-n$ és $a_{n+1}=n+1$. A megoldások közül csak az $a_{n+1}=n+1$ pozitív és ez pontosan az, amit bizonyítani akartunk.

Tehát minden $n \in N^{+}$esetén $a_{n}=n$. 
Megjegyzés

A feladat megoldásának szemléletes bizonyítása (F.4. ábra):

$$
\begin{aligned}
& 1+2+3+\ldots+n=\frac{1}{2} \cdot n(n+1) \\
& 1^{3}+2^{3}+3^{3}+\ldots+n^{3}=\left(\frac{1}{2} \cdot n(n+1)\right)^{2}
\end{aligned}
$$

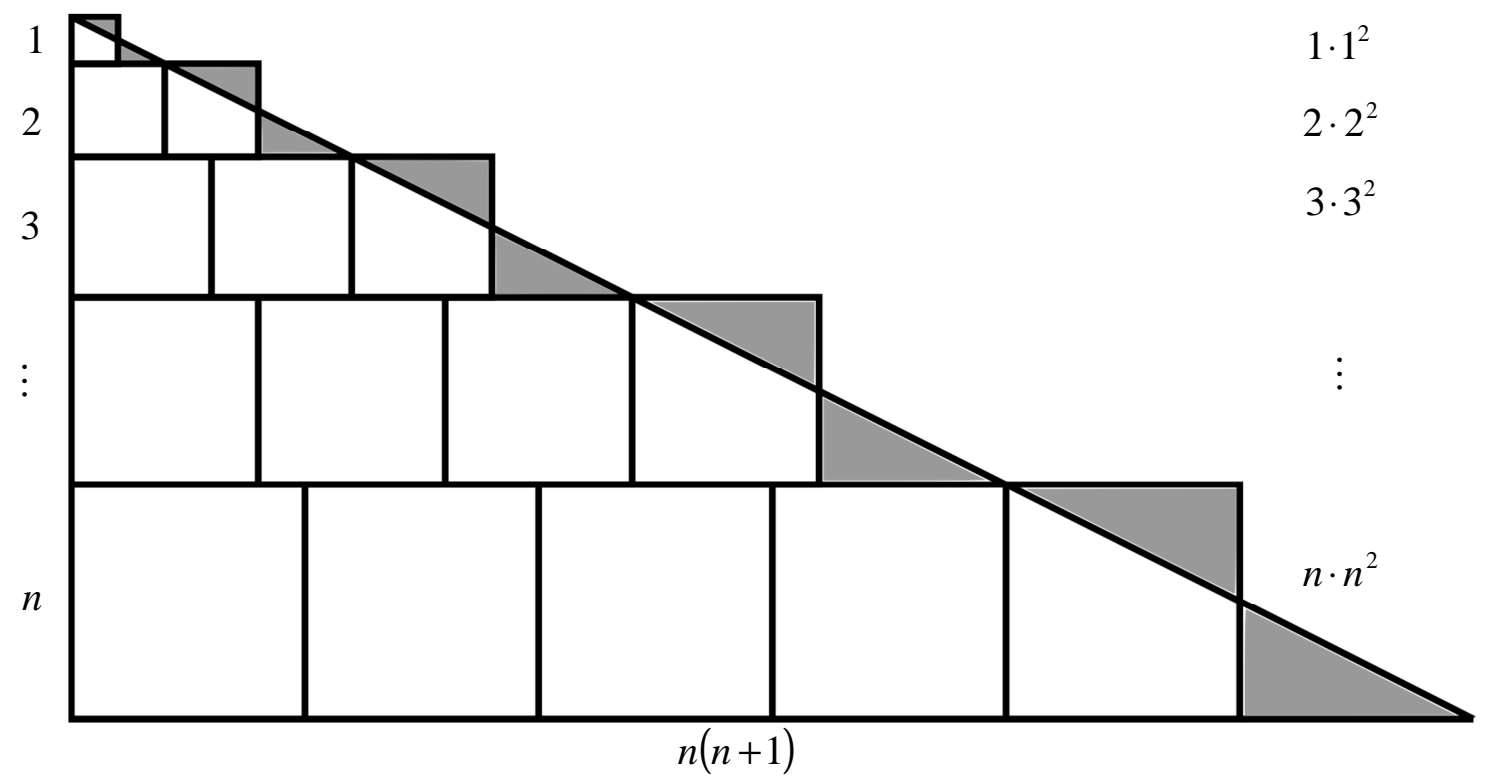

F.4. ábra

Megjegyzés

Bebizonyítható egy ennél élesebb állítás is, éspedig:

ha $a_{1}<a_{2}<\ldots<a_{n}$ pozitív egészek, akkor $a_{1}^{3}+a_{2}^{3}+\ldots+a_{n}^{3} \geq\left(a_{1}+a_{2}+\ldots+a_{n}\right)^{2}$, ahol az egyenlöség akkor és csak akkor áll fenn, ha $a_{k}=k$ minden $k=1,2, \ldots, n$ esetén.

Az egyenlőtlenség igazolása szintén a teljes indukció módszerével történik.

Ha $n=1$, akkor az $a_{1} \geq 1$-böl következik, hogy $a_{1}^{3} \geq a_{1}^{2}$, illetve hogy az $a_{1}^{3}=a_{1}^{2}$ egyenlőség csak akkor teljesül, ha $a_{1}=1$.

Tegyük fel, hogy az állítás igaz, ha $n=k$ és lássuk be, hogy igaz $n=k+1$ esetén is.

Tekintsünk $k+1$ darab pozitív egész számot úgy, hogy $a_{1}<a_{2}<\ldots<a_{k}<a_{k+1}$.

Mivel $a_{k+1} \geq a_{k}+1$, ezért $\frac{\left(a_{k+1}-1\right) \cdot a_{k+1}}{2} \geq \frac{a_{k} \cdot\left(a_{k}+1\right)}{2}=1+2+3+\ldots+a_{k}$.

$\mathrm{Az} 1+2+3+\ldots+a_{k}$ összeg az összes $a_{k}$-nál nem nagyobb pozitív egész összege, ezért ez az összeg biztosan nagyobb vagy egyenlő az $a_{1}+a_{2}+\ldots+a_{k}$ összegnél, melynek tagjai különböző egészek az 1,2,3, .., $a_{k}$ egészek közül. Így

$\frac{\left(a_{k+1}-1\right) \cdot a_{k+1}}{2} \geq a_{1}+a_{2}+\ldots+a_{k}$,

amit végigszorozva $2 a_{k+1}$-gyel és átrendezve az

$a_{k+1}^{3} \geq 2\left(a_{1}+a_{2}+\ldots+a_{k}\right) \cdot a_{k+1}+a_{k+1}^{2}$ 
egyenlőtlenséghez jutunk.

Felhasználva, hogy az indukciós feltétel szerint $a_{1}^{3}+a_{2}^{3}+\ldots+a_{k}^{3} \geq\left(a_{1}+a_{2}+\ldots+a_{k}\right)^{2}$ kapjuk, hogy

$a_{1}^{3}+a_{2}^{3}+\ldots+a_{k}^{3}+a_{k+1}^{3} \geq\left(a_{1}+a_{2}+\ldots+a_{k}\right)^{2}+a_{k+1}^{3} \geq$

$\geq\left(a_{1}+a_{2}+\ldots+a_{k}\right)^{2}+2\left(a_{1}+a_{2}+\ldots+a_{k}\right) \cdot a_{k+1}+a_{k+1}^{2}=\left(a_{1}+a_{2}+\ldots+a_{k}+a_{k+1}\right)^{2}$,

azaz, hogy az egyenlőtlenség igaz $n=k+1$ esetben is.

Nem nehéz belátni, hogy a fenti összefüggésben az egyenlőség csak akkor állhat fenn, ha

$a_{k+1}=a_{k}+1$ és $a_{1}^{3}+a_{2}^{3}+\ldots+a_{k}^{3}=\left(a_{1}+a_{2}+\ldots+a_{k}\right)^{2}$.

Ez utóbbi egyenlőségben az indukciós feltétel alapján az egyenlőség csak akkor áll fenn, ha $a_{1}=1, a_{1}=2, \ldots, a_{k}=k$. Mivel $a_{k+1}=a_{k}+1$ adódik, hogy $a_{k+1}=k+1$, azaz minden $k=1,2, \ldots, n$ esetén $a_{k}=k$.

Megfordítva, ha $a_{1}=1, a_{1}=2, \ldots, a_{k}=k, a_{k+1}=k+1$, akkor az egyenlőség fennáll, hiszen ha az $S_{3}$-ban az $n$ helyére $(k+1)$-t írunk:

$1^{3}+2^{3}+\ldots+k^{3}+(k+1)^{3}=[1+2+\ldots+k+(k+1)]^{2}$.

29. Az $a_{1}, a_{2}, \ldots, a_{n}$ számok különböző pozitív egészek. Bizonyítsuk be, hogy:

$\left(a_{1}^{7}+a_{2}^{7}+\ldots+a_{n}^{7}\right)+\left(a_{1}^{5}+a_{2}^{5}+\ldots+a_{n}^{5}\right) \geq 2\left(a_{1}^{3}+a_{2}^{3}+\ldots+a_{n}^{3}\right)^{2}$.

\section{Megoldás}

A bizonyítandó egyenlötlenség a 3.2.3. fejezetben levezetett $2 \cdot S_{1}^{4}=S_{7}+S_{5}=2 \cdot S_{3}^{2}$ összefüggés egy „élesebb” változata.

Mivel az $a_{i}$-k különbözőek, feltehetjük, hogy $a_{1}<a_{2}<\ldots<a_{n}$. A feladatot az $n$-re vonatkozó teljes indukcióval fogjuk megoldani.

Ha $n=1$, akkor az $a_{1}^{7}+a_{1}^{5} \geq 2 a_{1}^{6}$ bizonyítandó. Ez belátható, hiszen mivel $a_{1} \geq 1$, ezért $a_{1}^{7}+a_{1}^{5}-2 a_{1}^{6}=a_{1}^{5} \cdot\left(a_{1}^{2}+1-2 a_{1}\right)=a_{1}^{5} \cdot\left(a_{1}-1\right)^{2} \geq 0$,

ahol az egyenlőség csak akkor áll fenn, ha $a_{1}=1$.

Tegyük fel ezután, hogy valamely $k$-ra teljesül a feladat állítása, majd mutassuk meg, hogy ekkor teljesül a következő is (tetszőleges $a_{1}<a_{2}<\ldots<a_{k}<a_{k+1}$ pozitív egészekre):

$\left(a_{1}^{7}+a_{2}^{7}+\ldots+a_{k}^{7}+a_{k+1}^{7}\right)+\left(a_{1}^{5}+a_{2}^{5}+\ldots+a_{k}^{5}+a_{k+1}^{5}\right) \geq 2\left(a_{1}^{3}+a_{2}^{3}+\ldots+a_{k}^{3}+a_{k+1}^{3}\right)^{2}$,

azaz

$\left(a_{1}^{7}+a_{2}^{7}+\ldots+a_{k}^{7}\right)+\left(a_{1}^{5}+a_{2}^{5}+\ldots+a_{k}^{5}\right)+a_{k+1}^{7}+a_{k+1}^{5} \geq$

$\geq 2\left(a_{1}^{3}+a_{2}^{3}+\ldots+a_{k}^{3}\right)^{2}+4\left(a_{1}^{3}+a_{2}^{3}+\ldots+a_{k}^{3}\right) \cdot a_{k+1}^{3}+2 a_{k+1}^{6}$.

$\mathrm{Az}$ indukciós feltevés következtében a bal oldalon lévő két zárójeles kifejezés összege nem kisebb, mint a jobb oldal első tagja, ezért elegendő azt bizonyítani, hogy

$a_{k+1}^{7}+a_{k+1}^{5} \geq 4\left(a_{1}^{3}+a_{2}^{3}+\ldots+a_{k}^{3}\right) \cdot a_{k+1}^{3}+2 a_{k+1}^{6}$.

Osszuk el mindkét oldalt $a_{k+1}^{3}$-nel, és rendezzük át a következőképpen:

$a_{k+1}^{4}+a_{k+1}^{2}-2 a_{k+1}^{3} \geq 4\left(a_{1}^{3}+a_{2}^{3}+\ldots+a_{k}^{3}\right)$. 
Tehát azt kell belátnunk, hogy:

$a_{1}^{3}+a_{2}^{3}+\ldots+a_{k}^{3} \leq \frac{a_{k+1}^{4}+a_{k+1}^{2}-2 a_{k+1}^{3}}{4}=\frac{\left(a_{k+1}^{2}-a_{k+1}\right)^{2}}{4}=\left[\frac{\left(a_{k+1}-1\right) \cdot a_{k+1}}{2}\right]^{2}$.

Felhasználva, hogy $1^{3}+2^{3}+\ldots+n^{3}=\left[\frac{n(n+1)}{2}\right]^{2}$ és az $n$ helyébe $\left(a_{k+1}-1\right)$-et írva:

$1^{3}+2^{3}+\ldots+\left(a_{k+1}-1\right)^{3}=\left[\frac{\left(a_{k+1}-1\right) \cdot a_{k+1}}{2}\right]^{2}$.

Mivel $a_{1}<a_{2}<\ldots<a_{k}<a_{k+1}$ és az $1^{3}+2^{3}+\ldots+\left(a_{k+1}-1\right)^{3}$ összeg az összes $\left(a_{k+1}-1\right)$-nél nem nagyobb pozitív egészek köbeinek összege, ezért ez az összeg biztosan nagyobb vagy egyenlő az $a_{1}^{3}+a_{2}^{3}+\ldots+a_{k}^{3}$ összegnél, melynek tagjai az $1,2,3, \ldots, a_{k}$ egészek közül vett különböző egészek köbei. Így:

$1^{3}+2^{3}+\ldots+\left(a_{k+1}-1\right)^{3}=\left[\frac{\left(a_{k+1}-1\right) \cdot a_{k+1}}{2}\right]^{2} \geq a_{1}^{3}+a_{2}^{3}+\ldots+a_{k}^{3}$,

és ez az, amit bizonyítanunk kellett.

Az előző feladat megjegyzésében leírtakhoz hasonló módon látható be az a tény is, hogy az egyenlőség akkor és csak akkor áll fenn, ha $a_{k}=k$ minden $k=1,2, \ldots, n$ esetén.

30. Számítsuk ki az

$x_{n}=\left(1+\frac{1}{n^{p+1}}\right) \cdot\left(1+\frac{2}{n^{p+1}}\right) \cdot\left(1+\frac{3}{n^{p+1}}\right) \cdot \ldots \cdot\left(1+\frac{n^{p}}{n^{p+1}}\right)$

általános tagú $\left\{x_{n}\right\}_{n \geq 1}$ sorozat határértékét, ahol $n$ és $p$ pozitív egész számok.

Megoldás

Legyen $n \in Z^{+}$rögzített szám.

Megmutatjuk, hogy

$\frac{n}{n+1} \cdot x \leq \ln (1+x) \leq x$

bármely $x \in\left[0, \frac{1}{n}\right]$ esetén.

Tekintsük a következö függvényt: $f_{1}(x)=\frac{n}{n+1} \cdot x-\ln (1+x)$, ahol $x \in\left[0, \frac{1}{n}\right]$. Az adott $x$ ek mellett az $f_{1}^{\prime}(x)=\frac{n}{n+1}-\frac{1}{1+x}=\frac{n x-1}{(n+1)(x+1)} \leq 0$ és mivel $f_{1}(0)=0$, következik hogy $f_{1}(x) \leq 0$, azaz teljesül, hogy $\frac{n}{n+1} \cdot x \leq \ln (1+x)$, minden $x \in\left[0, \frac{1}{n}\right]$ esetén.

Legyen most $f_{2}(x)=x-\ln (1+x)$, ahol $x \in\left[0, \frac{1}{n}\right]$. Ekkor $f_{2}^{\prime}(x)=1-\frac{1}{1+x}=\frac{x}{x+1} \geq 0$ és $f_{2}(0)=0$, tehát $f_{2}(x) \geq 0$, ahonnan következik, hogy $x \geq \ln (1+x)$, ha $x \in\left[0, \frac{1}{n}\right]$ (ez utóbbi egyenlőtlenség bármely $x \geq 0$ esetén igaz). 
Mivel $\frac{1}{n^{p+1}}, \frac{2}{n^{p+1}}, \frac{3}{n^{p+1}}, \ldots, \frac{n^{p}}{n^{p+1}} \in\left[0, \frac{1}{n}\right]$, ezeket az értékeket rendre behelyettesítjük a (*) egyenlőtlenségbe:

$$
\begin{aligned}
& \frac{n}{n+1} \cdot \frac{1}{n^{p+1}} \leq \ln \left(1+\frac{1}{n^{p+1}}\right) \leq \frac{1}{n^{p+1}} \\
& \frac{n}{n+1} \cdot \frac{2}{n^{p+1}} \leq \ln \left(1+\frac{2}{n^{p+1}}\right) \leq \frac{2}{n^{p+1}} \\
& \frac{n}{n+1} \cdot \frac{3}{n^{p+1}} \leq \ln \left(1+\frac{3}{n^{p+1}}\right) \leq \frac{3}{n^{p+1}}
\end{aligned}
$$

$\frac{n}{n+1} \cdot \frac{n^{p}}{n^{p+1}} \leq \ln \left(1+\frac{n^{p}}{n^{p+1}}\right) \leq \frac{n^{p}}{n^{p+1}}$

A kapott egyenlötlenségek megfelelő oldalait összegezve, felírható, hogy

$$
\frac{n}{n+1} \cdot \frac{1+2+3+\ldots+n^{p}}{n^{p+1}} \leq \ln x_{n} \leq \frac{1+2+3+\ldots+n^{p}}{n^{p+1}} \text {. }
$$

De $\frac{1+2+3+\ldots+n^{p}}{n^{p+1}}=\frac{\frac{n^{p}}{2} \cdot\left(n^{p}+1\right)}{n^{p+1}}=\frac{n^{p}+1}{2 n}$ és $\lim _{n \rightarrow \infty} \frac{n^{p}+1}{2 n}=\left\{\begin{array}{l}\frac{1}{2}, \text { ha } p=1 \\ \infty, \text { ha } p \geq 2\end{array}\right.$.

Innen (a rendőr-elvet felhasználva) felírhatjuk, hogy $\lim _{n \rightarrow \infty}\left(\ln x_{n}\right)=\left\{\begin{array}{l}\frac{1}{2}, \text { ha } p=1 \\ \infty, \text { ha } p \geq 2\end{array}\right.$,

ahonnan $\lim _{n \rightarrow \infty} x_{n}=\left\{\begin{array}{l}\sqrt{e}, \text { ha } p=1 \\ \infty, \text { ha } p \geq 2\end{array}\right.$.

31. Adott $p$ pozitív egész szám esetén legyen $a_{n}=1^{p}+2^{p}+\ldots+n^{p}-k \cdot n^{p+1}$ bármely pozitív egész $n$ esetén. Mely $k \in R$ esetén konvergens az $\left\{a_{n}\right\}_{n \geq 1}$ sorozat?

Megoldás

Ha $p=1$, akkor $a_{n}=1+2+\ldots+n-k \cdot n^{2}=\frac{n(n+1)}{2}-k \cdot n^{2}$.

Ebben az esetben:

$$
\lim _{n \rightarrow \infty} a_{n}=\lim _{n \rightarrow \infty}\left(\frac{n^{2}+n}{2}-k \cdot n^{2}\right)=\lim _{n \rightarrow \infty} n^{2} \cdot\left(\frac{1}{2}-k+\frac{1}{2 n}\right)=\left\{\begin{array}{l}
+\infty, \text { ha } k \leq \frac{1}{2} \\
-\infty, \text { ha } k>\frac{1}{2}
\end{array} .\right.
$$

Tehát $p=1$ esetén a sorozat egyetlen valós $k$-ra sem konvergens.

A teljes indukció módszerének segítségével be fogjuk látni, hogy bármely pozitív egész $p$ esetén hasonló a helyzet. 
Legyen $S_{p}=1^{p}+2^{p}+3^{p}+\ldots+n^{p}$.

Teljes indukcióval igazoljuk, hogy az $S_{p}$ az $n$-nek $(p+1)$-edfokú polinomja úgy, hogy a $(p+1)$-edfokú tag együtthatója $\frac{1}{p+1}$, míg a $p$-edfokú tagé $\frac{1}{2}$.

Mivel $1+2+3+\ldots+n=\frac{n(n+1)}{2}=\frac{1}{2} \cdot n^{2}+\frac{1}{2} \cdot n$, az állítás $p=1$ esetben igaz.

A folytatásban felhasználjuk a 3.3.1.fejezetben levezetett azonosságot:

$$
(n+1)^{p+1}-1=\left(\begin{array}{c}
p+1 \\
1
\end{array}\right) \cdot S_{p}+\left(\begin{array}{c}
p+1 \\
2
\end{array}\right) \cdot S_{p-1}+\left(\begin{array}{c}
p+1 \\
3
\end{array}\right) \cdot S_{p-2}+\ldots+\left(\begin{array}{c}
p+1 \\
p
\end{array}\right) \cdot S_{1}+\left(\begin{array}{c}
p+1 \\
p+1
\end{array}\right) \cdot n .
$$

A kapott összefüggés bal oldalára alkalmazva Newton binomiális tételét, majd felhasználva, hogy $\left(\begin{array}{c}p+1 \\ 1\end{array}\right)=p+1$, kapjuk, hogy

$$
\begin{aligned}
& n^{p+1}+\left(\begin{array}{c}
p+1 \\
1
\end{array}\right) \cdot n^{p}+\left(\begin{array}{c}
p+1 \\
2
\end{array}\right) \cdot n^{p-1}+\ldots+\left(\begin{array}{c}
p+1 \\
p
\end{array}\right) \cdot n= \\
& =(p+1) \cdot S_{p}+\left(\begin{array}{c}
p+1 \\
2
\end{array}\right) \cdot S_{p-1}+\left(\begin{array}{c}
p+1 \\
3
\end{array}\right) \cdot S_{p-2}+\ldots+\left(\begin{array}{c}
p+1 \\
p
\end{array}\right) \cdot S_{1}+\left(\begin{array}{c}
p+1 \\
p+1
\end{array}\right) \cdot n .
\end{aligned}
$$

Tegyük fel, hogy $p$-nél kisebb kitevőkre igaz az állítás és fejezzük ki a kapott összefüggésből az $S_{p}$-t:

$$
\begin{aligned}
& S_{p}=\frac{\left[n^{p+1}+\left(\begin{array}{c}
p+1 \\
1
\end{array}\right) \cdot n^{p}+\left(\begin{array}{c}
p+1 \\
2
\end{array}\right) \cdot n^{p-1}+\ldots+\left(\begin{array}{c}
p+1 \\
p
\end{array}\right) \cdot n-\left(\begin{array}{c}
p+1 \\
2
\end{array}\right) \cdot S_{p-1}-\ldots-\left(\begin{array}{c}
p+1 \\
p
\end{array}\right) \cdot S_{1}\right]}{p+1}= \\
& =\frac{1}{p+1} \cdot n^{p+1}+\left[1-\frac{1}{p+1} \cdot\left(\begin{array}{c}
p+1 \\
2
\end{array}\right) \cdot \frac{1}{p}\right] \cdot n^{p}+R(n),
\end{aligned}
$$

ahol az $R(n)$ legfeljebb $(p-1)$-edfokú polinom. Felhasználva, hogy $\left(\begin{array}{c}p+1 \\ 2\end{array}\right)=\frac{(p+1) p}{2}$ a kapott összefüggés átalakul $S_{p}=\frac{1}{p+1} \cdot n^{p+1}+\frac{1}{2} \cdot n^{p}+R(n)$ alakra, tehát az állítás igaz $p$-re is.

Mindezek alapján:

$$
\begin{aligned}
& \lim _{n \rightarrow \infty} a_{n}=\lim _{n \rightarrow \infty}\left(S_{p}-k \cdot n^{p+1}\right)=\lim _{n \rightarrow \infty}\left(\frac{1}{p+1} \cdot n^{p+1}+\frac{1}{2} \cdot n^{p}+R(n)-k \cdot n^{p+1}\right)= \\
& =\lim _{n \rightarrow \infty} n^{p+1} \cdot\left(\frac{1}{p+1}-k+\frac{1}{2 n}+\frac{R(n)}{n^{p+1}}\right)=\left\{\begin{array}{l}
+\infty, \text { ha } k \leq \frac{1}{p+1} \\
-\infty, \text { ha } k>\frac{1}{p+1}
\end{array}\right.
\end{aligned}
$$

Ezzel az állítást beláttuk. 
32. Tekintsük azt az n-edrendü determinánst, amelynek oszlopaiban különböző számtani sorozatok egymást követő tagjainak azonos ( $p$-edfokú) hatványai szerepelnek, azaz

$$
D_{n}^{p}=\left|\begin{array}{cccc}
x_{1}^{p} & x_{2}^{p} & \ldots & x_{n}^{p} \\
\left(x_{1}+\alpha_{1}\right)^{p} & \left(x_{2}+\alpha_{2}\right)^{p} & \ldots & \left(x_{n}+\alpha_{n}\right)^{p} \\
\left(x_{1}+2 \alpha_{1}\right)^{p} & \left(x_{2}+2 \alpha_{2}\right)^{p} & \ldots & \left(x_{n}+2 \alpha_{n}\right)^{p} \\
------- & ------- & --- & ------- \\
{\left[x_{1}+(n-1) \cdot \alpha_{1}\right]^{p}} & {\left[x_{2}+(n-1) \cdot \alpha_{2}\right]^{p}} & \ldots & {\left[x_{n}+(n-1) \cdot \alpha_{n}\right]^{p}}
\end{array}\right|,
$$

ahol $\alpha_{i} \neq 0, i=1,2, \ldots, n$.

Bizonyítsuk be:

a) Ha $p<n-1$, akkor $D_{n}^{p}=0$.

b) Ha $p=n-1$, akkor $D_{n}^{n-1}$ felbontható $\left(\begin{array}{l}n \\ 2\end{array}\right)$ darab másodrendü determináns szorzatára.

c) Ha $p>n-1$, akkor $D_{n}^{p}$ determináns osztható a $D_{n}^{n-1}$-gyel.

\section{Megoldás}

a)

Mivel $\alpha_{i} \neq 0 \quad(i=1,2, \ldots, n)$, ezért rendre kiemelhetjük a megfelelő oszlopokból a megfelelő számtani sorozat differenciáját a $p$-edik hatványon.

Így:

$$
D_{n}^{p}=\alpha_{1}^{p} \cdot \alpha_{2}^{p} \cdot \ldots \cdot \alpha_{n}^{p} \cdot\left|\begin{array}{cccc}
x_{1}^{p} & x_{2}^{p} & \cdots & x_{n}^{p} \\
\left(\frac{x_{1}}{\alpha_{1}}+1\right)^{p} & \left(\frac{x_{2}}{\alpha_{2}}+1\right)^{p} & \cdots & \left(\frac{x_{n}}{\alpha_{n}}+1\right)^{p} \\
\left(\frac{x_{1}}{\alpha_{1}}+2\right)^{p} & \left(\frac{x_{2}}{\alpha_{2}}+2\right)^{p} & \cdots & \left(\frac{x_{n}}{\alpha_{n}}+2\right)^{p} \\
------ & ------- & --- & ------- \\
\left(\frac{x_{1}}{\alpha_{1}}+n-1\right)^{p} & \left(\frac{x_{2}}{\alpha_{2}}+n-1\right)^{p} & \cdots & \left(\frac{x_{n}}{\alpha_{n}}+n-1\right)^{p}
\end{array}\right|
$$

Ha az (1) alatti determinánst kifejtjük az első oszlopa szerint, akkor egy legfeljebb pedfokú polinomot kapunk $\left(\frac{x_{1}}{\alpha_{1}}\right)$-ben.

$\mathrm{Az}$ is észrevehetö, hogy ha fennáll az $\frac{x_{1}}{\alpha_{1}}=\frac{x_{2}}{\alpha_{2}}$ egyenlőség, akkor az (1) alatti determináns értéke nulla, hiszen a determináns első két oszlopa megegyezik. Hasonlóan belátható, hogy a determináns értéke szintén 0 lesz, ha teljesül $\frac{x_{1}}{\alpha_{1}}=\frac{x_{3}}{\alpha_{3}}, \ldots, \frac{x_{1}}{\alpha_{1}}=\frac{x_{n}}{\alpha_{n}}$ egyenlőségek valamelyike. Ez azt jelenti, hogy a determináns zéró lesz $\left(\frac{x_{1}}{\alpha_{1}}\right)$-nek $(n-1)$ darab értéke esetén. 
Figyelembe véve, hogy $p<n-1$, azt kaptuk, hogy az adott polinomnak a fokszámánál több zérushelye van. Ez csak akkor lehetséges, ha a polinom a zéruspolinom.

Tehát $D_{n}^{1}=D_{n}^{2}=\ldots=D_{n}^{n-2} \equiv 0$.

$\underline{b)}$

Az a) pont bizonyításában leírtak alapján az adott determináns osztható $\left(\frac{x_{1}}{\alpha_{1}}-\frac{x_{2}}{\alpha_{2}}\right)$-gyel vagy $\left(x_{1} \cdot \alpha_{2}-x_{2} \cdot \alpha_{1}\right)$-gyel. Hasonlóan osztható lesz az $\left(x_{1} \cdot \alpha_{3}-x_{3} \cdot \alpha_{1}\right), \ldots$, $\left(x_{1} \cdot \alpha_{n}-x_{n} \cdot \alpha_{1}\right), \quad\left(x_{2} \cdot \alpha_{3}-x_{3} \cdot \alpha_{2}\right), \quad\left(x_{2} \cdot \alpha_{4}-x_{4} \cdot \alpha_{2}\right), \ldots, \quad\left(x_{2} \cdot \alpha_{n}-x_{n} \cdot \alpha_{2}\right) \quad$ stb. mindegyikével, tehát felírható, hogy

$$
\begin{aligned}
& D_{n}^{n-1}=c \cdot\left(\left|\begin{array}{ll}
x_{1} & x_{2} \\
\alpha_{1} & \alpha_{2}
\end{array}\right| \cdot\left|\begin{array}{ll}
x_{1} & x_{3} \\
\alpha_{1} & \alpha_{3}
\end{array}\right| \cdot\left|\begin{array}{ll}
x_{1} & x_{4} \\
\alpha_{1} & \alpha_{4}
\end{array}\right| \cdot \ldots \cdot\left|\begin{array}{ll}
x_{1} & x_{n} \\
\alpha_{1} & \alpha_{n}
\end{array}\right|\right) \cdot\left(\left|\begin{array}{ll}
x_{2} & x_{3} \\
\alpha_{2} & \alpha_{3}
\end{array}\right| \cdot\left|\begin{array}{ll}
x_{2} & x_{4} \\
\alpha_{2} & \alpha_{4}
\end{array}\right| \cdot \ldots \cdot\left|\begin{array}{ll}
x_{2} & x_{n} \\
\alpha_{2} & \alpha_{n}
\end{array}\right|\right) \cdot \\
& \cdot\left(\left|\begin{array}{ll}
x_{3} & x_{4} \\
\alpha_{3} & \alpha_{4}
\end{array}\right| \cdot \ldots \cdot\left|\begin{array}{ll}
x_{3} & x_{n} \\
\alpha_{3} & \alpha_{n}
\end{array}\right|\right) \cdot \ldots \cdot\left(\left|\begin{array}{ll}
x_{n-1} & x_{n} \\
\alpha_{n-1} & \alpha_{n}
\end{array}\right|\right),
\end{aligned}
$$

és ez az amit bizonyítani akartunk.

\section{Megjegyzés}

Az (1) alapján belátható, hogy egyfelől $D_{n}^{n-1}$ egy $(n-1)$-edfokú polinom mindegyik $x_{1}, x_{2}, \ldots, x_{n}, \alpha_{1}, \alpha_{2}, \ldots, \alpha_{n}$ változójára nézve, másrészt pedig a (2) összefüggés jobb oldalán szereplő másodrendủ determinánsok szorzata szintén egy $(n-1)$-edfokú polinom mindegyik $x_{1}, x_{2}, \ldots, x_{n}, \alpha_{1}, \alpha_{2}, \ldots, \alpha_{n}$ változójára nézve. Innen következik, hogy a (2) összefüggésben szereplő $c$ tényező nem függ $x_{1}, x_{2}, \ldots, x_{n}, \alpha_{1}, \alpha_{2}, \ldots, \alpha_{n}$ változóktól.

Ahhoz, hogy meghatározzuk a $c$ tényezőt, a változóknak konkrét értékeket adunk.

Legyenek $\alpha_{1}=\alpha_{2}=\ldots=\alpha_{n}=1$, illetve $x_{1}=n, x_{2}=n-1, \ldots, x_{n}=1$. Felhasználva a (2) alatti összefüggést:

$$
\left|\begin{array}{cccc}
n^{n-1} & (n-1)^{n-1} & \ldots & 1^{n-1} \\
(n+1)^{n-1} & n^{n-1} & \ldots & 2^{n-1} \\
(n+2)^{n-1} & (n+1)^{n-1} & \ldots & 3^{n-1} \\
------- & ------- & --- & ------- \\
(2 n-1)^{n-1} & (2 n-2)^{n-1} & \ldots & n^{n-1}
\end{array}\right|=c \cdot(n-1) ! \cdot(n-2) ! \cdot \ldots \cdot 2 ! \cdot 1 ! .
$$

A (3) alatti determináns - melyet nevezzünk el $\delta$-nak - kiszámításához felhasználjuk a 4.1.1 fejezetben már ismertetett tényt, éspedig, hogy ha $P(x)$ egy $p$-edfokú polinom és az $a_{1}, a_{2}, \ldots, a_{n}, \ldots$ egy olyan számtani sorozat, melynek differenciája $d$, akkor a $P\left(a_{1}\right), P\left(a_{2}\right), \ldots, P\left(a_{n}\right), \ldots$ sorozat $p$-edik differenciasorozata állandó és ennek az állandónak az értéke $A_{0} \cdot p ! \cdot d^{p}$, ahol $A_{0}$ az $x^{p}$ együtthatója a $P(x)$ polinomban.

Legyen $P(x)=x^{n-1}$ és tekintsük a következő sorozatot: $a_{1}=1^{n-1} ; a_{2}=2^{n-1} ; a_{3}=3^{n-1} ; \ldots$; $a_{n}=n^{n-1} ; a_{n+1}=(n+1)^{n-1} ; \ldots$. 
Így azt kapjuk, hogy:

$$
\delta=\left|\begin{array}{cccccc}
a_{n} & a_{n-1} & a_{n-2} & \ldots & a_{2} & a_{1} \\
a_{n+1} & a_{n} & a_{n-1} & \ldots & a_{3} & a_{2} \\
a_{n+2} & a_{n+1} & a_{n} & \ldots & a_{4} & a_{3} \\
--- & --- & --- & --- & --- & --- \\
a_{2 n-1} & a_{2 n-2} & a_{2 n-3} & \ldots & a_{n+1} & a_{n}
\end{array}\right| .
$$

Vonjuk ki minden oszlopból a tőle jobbra lévő oszlopot, így minden sorban a sor tagjaiból álló sorozat első differenciasorozatát kapjuk. Az így kapott determinánsban ismételjük meg az előbbi eljárást az utolsó oszlop kivételével, az újonnan kapott determinánsban újra megismételve ezúttal az utolsó két oszlop kivételével és így tovább, addig, amíg az első oszlopban az $(n-1)$-edik differenciát kapjuk. Ezáltal:

$$
\delta=\left|\begin{array}{cccccc}
\Delta^{n-1} a_{1} & \Delta^{n-2} a_{1} & \Delta^{n-3} a_{1} & \ldots & \Delta^{1} a_{1} & a_{1} \\
\Delta^{n-1} a_{2} & \Delta^{n-2} a_{2} & \Delta^{n-3} a_{2} & \ldots & \Delta^{1} a_{2} & a_{2} \\
\Delta^{n-1} a_{3} & \Delta^{n-2} a_{3} & \Delta^{n-3} a_{3} & \ldots & \Delta^{1} a_{3} & a_{3} \\
---- & ---- & ---- & --- & --- & --- \\
\Delta^{n-1} a_{n} & \Delta^{n-2} a_{n} & \Delta^{n-3} a_{n} & \ldots & \Delta^{1} a_{n} & a_{n}
\end{array}\right| .
$$

Figyelembe véve a differenciasorozat tulajdonságait, a kapott determináns első oszlopának minden eleme $(n-1)$ ! lesz.

Alkalmazzuk az előbbi algoritmust erre az új determinánsra, azzal a változással, hogy ezúttal minden sorból vonjuk ki a felette lévőt. Így egy olyan determinánst kapunk, melyben az első oszlop minden eleme - az elsőt kivéve - 0. Az így kapott determinánsban ismételjük meg az előbbi eljárást az első sor kivételével, az újonnan kapott determinánsban újra megismételve ezúttal az első két sor kivételével stb., míg végül a következő determinánshoz jutunk:

$$
\delta=\left|\begin{array}{cccccc}
\Delta^{n-1} a_{1} & \Delta^{n-2} a_{1} & \Delta^{n-3} a_{1} & \ldots & \Delta^{1} a_{1} & a_{1} \\
0 & \Delta^{n-1} a_{1} & \Delta^{n-2} a_{1} & \ldots & \Delta^{2} a_{1} & \Delta^{1} a_{1} \\
0 & 0 & \Delta^{n-1} a_{1} & \ldots & \Delta^{3} a_{1} & \Delta^{2} a_{1} \\
---- & ---- & ---- & --- & ---- & ---- \\
0 & 0 & 0 & \ldots & \Delta^{n-1} a_{1} & \Delta^{n-2} a_{1} \\
0 & 0 & 0 & \ldots & 0 & \Delta^{n-1} a_{1}
\end{array}\right| .
$$

Mivel a kapott determináns egy felső háromszögmátrix determinánsa, ezért:

$\delta=\left(\Delta^{n-1} a_{1}\right)^{n}=[(n-1) !]^{n}$.

A kapott értéket behelyettesítve a (3) összefüggésbe kapjuk, hogy

$[(n-1) !]^{n}=c \cdot(n-1) ! \cdot(n-2) ! \cdot \ldots \cdot 2 ! \cdot 1 !$

$c=\frac{[(n-1) !]^{n}}{(n-1) ! \cdot(n-2) ! \ldots \cdot 2 ! \cdot 1 !}=\frac{[(n-1) !]^{n-1}}{(n-2) ! \cdot \ldots \cdot 2 ! \cdot 1 !}$.

A kapott $c$ együtthatót behelyettesítve a (2) összefüggésbe megkapjuk a $D_{n}^{n-1}$ tényezőkre bontott alakját. 
$\underline{\text { c) }}$

Tetszőleges $p>n-1$ esetén a $D_{n}^{p}$ determináns tartalmazza a $D_{n}^{n-1}$ mindegyik tényezőjét, mivel zéróvá válik, ha $\frac{x_{1}}{\alpha_{1}}=\frac{x_{2}}{\alpha_{2}} ; \frac{x_{1}}{\alpha_{1}}=\frac{x_{3}}{\alpha_{3}} ;$ stb. A $D_{n}^{p}$ determináns egy $p$-edfokú polinomja $x_{1}$-nek, míg $D_{n}^{n-1}$ pedig egy $(n-1)$-ed fokú polinomja lesz $x_{1}$-nek, ezért azokon a tényezőkön kívül, amelyek tartalmazzák az $x_{1}$-et és szerepelnek a $D_{n}^{n-1}$ felbontásában, még létezik $x_{1}$-nek egy $[p-(n-1)]$-edfokú tényezője is. Hasonló elgondolás alapján létezik $x_{2}$-nek is egy $[p-(n-1)]$-edfokú tényezője stb. Mivel mind $D_{n}^{p}$, mind pedig $D_{n}^{n-1}$ homogén polinomok mindegyik $x_{1}, x_{2}, \ldots, x_{n}, \alpha_{1}, \alpha_{2}, \ldots, \alpha_{n}$ változóra nézve, így a hányadosuk szintén homogén polinom ezen változók szerint, mely polinom fokszáma - minden változóra nézve - $[p-(n-1)]$.

Megjegyzés

Ha mindegyik számtani sorozatnak ugyanaz az állandó különbsége (legyen ez $d$ ), akkor a (2) és (4) alapján:

$D_{n}^{n-1}=\frac{[(n-1) !]^{n-1}}{(n-2) ! \cdot \ldots \cdot 2 ! \cdot 1 !} \cdot d^{\frac{(n-1) n}{2}} \cdot\left(x_{1}-x_{2}\right) \cdot\left(x_{1}-x_{3}\right) \cdot \ldots \cdot\left(x_{1}-x_{n}\right) \cdot\left(x_{2}-x_{3}\right) \cdot\left(x_{2}-x_{4}\right) \cdot \ldots \cdot$

$\cdot\left(x_{2}-x_{n}\right) \cdot\left(x_{3}-x_{4}\right) \cdot \ldots \cdot\left(x_{3}-x_{n}\right) \cdot \ldots \cdot\left(x_{n-1}-x_{n}\right)$.

Figyelembe véve, hogy

$\left(x_{1}-x_{2}\right) \cdot\left(x_{1}-x_{3}\right) \cdot \ldots \cdot\left(x_{1}-x_{n}\right) \cdot\left(x_{2}-x_{3}\right) \cdot\left(x_{2}-x_{4}\right) \cdot \ldots \cdot\left(x_{2}-x_{n}\right) \cdot \ldots \cdot\left(x_{n-1}-x_{n}\right)=$

$=(-1)^{\frac{(n-1) n}{2}} \cdot\left(x_{2}-x_{1}\right) \cdot\left(x_{3}-x_{1}\right) \cdot \ldots \cdot\left(x_{n}-x_{1}\right) \cdot\left(x_{3}-x_{2}\right) \cdot\left(x_{4}-x_{2}\right) \cdot \ldots \cdot\left(x_{n}-x_{2}\right) \cdot \ldots \cdot\left(x_{n}-x_{n-1}\right)$, ahol az $\left(x_{2}-x_{1}\right) \cdot\left(x_{3}-x_{1}\right) \cdot \ldots \cdot\left(x_{n}-x_{1}\right) \cdot\left(x_{3}-x_{2}\right) \cdot\left(x_{4}-x_{2}\right) \cdot \ldots \cdot\left(x_{n}-x_{2}\right) \cdot \ldots \cdot\left(x_{n}-x_{n-1}\right)$ szorzat éppen egy $n$-edrendủ Vandermonde determináns kifejtése, azt kapjuk hogy:

$D_{n}^{n-1}=(-1)^{\frac{(n-1) n}{2}} \cdot \frac{[(n-1) !]^{n-1}}{(n-2) ! \cdot \ldots \cdot 2 ! \cdot 1 !} \cdot d^{\frac{(n-1) n}{2}} \cdot V_{n}$.

Ha ezen felül az $x_{1}, x_{2}, \ldots, x_{n}$ ugyancsak egy számtani sorozat egymást követő tagjai, egy olyan sorozaté, amelynek differenciája $r$, akkor a Vandermonde determináns $V_{n}=1 ! \cdot 2 ! \cdot \ldots \cdot(n-2) ! \cdot(n-1) ! r^{\frac{(n-1) n}{2}}$ és az (5) összefüggés átírható a következő alakra:

$D_{n}^{n-1}=(-1)^{\frac{(n-1) n}{2}} \cdot[(n-1) !]^{n} \cdot(r d)^{\frac{(n-1) n}{2}}$. 